SOLANO DE CAMARGO

Forum shopping:

\title{
modo lícito de escolha de jurisdição?
}

Dissertação de Mestrado

Orientador: Professor Associado Doutor Gustavo Ferraz de Campos Monaco

UNIVERSIDADE DE SÃO PAULO

FACULDADE DE DIREITO

São Paulo-SP

2015 


\title{
Forum shopping:
}

\section{modo lícito de escolha de jurisdição?}

\begin{abstract}
Dissertação apresentada à Banca Examinadora do Programa de Pós-Graduação em Direito, da Faculdade de Direito da Universidade de São Paulo, como exigência parcial para obtenção do título de Mestre em Direito, na área de concentração Direito Internacional e Comparado, sob a orientação do Professor Associado Doutor Gustavo Ferraz de Campos Monaco.
\end{abstract}

UNIVERSIDADE DE SÃO PAULO

FACULDADE DE DIREITO

São Paulo-SP

2015 
BANCA EXAMINADORA 
À Elaine, por ter-me despertado para o mundo acadêmico.

À Sophia, pela paciência.

Ao meu orientador, professor Gustavo Ferraz de Campos Monaco, pelo direcionamento, dedicação paciência e, principalmente, pela amizade durante todo o processo.

Aos professores João Grandino Rodas e José Rogério Cruz e Tucci, pelas valiosas observações em meu exame de qualificação, todas elas presentes neste trabalho final.

Aos demais familiares, aos meus amigos do Largo de São Francisco e aos meus colegas da Lee, Brock \& Camargo Advogados, pelo companheirismo, amizade e apoio incondicional. 
$O$ direito de ter um caso julgado localmente e ser poupado da provável injustiça de ter de litigar em um foro oneroso ou distante é tão antigo quanto a Magna Carta.

Justice Black, Suprema Corte dos EUA

Nat'l Equip. Rental, Ltd. v. Szukhent, 375 US, 325 (1964)

"Forum shopping" é um termo chulo; porém, é apenas uma forma pejorativa de dizer que, se você oferecer a um demandante uma escolha de jurisdições, ele naturalmente vai escolher aquela em que imagina obter um resultado mais favorável: este fato não deve causar nem surpresa nem indignação.

Lord Simon of Glaisdale, Master of the Rolls

Corte de Apelações da Inglaterra e do País de Gales

Atlantic Star v. Bona Spes, [1974] A.C. 436, 471 (opinion of Lord Simon). 


\section{RESUMO}

CAMARGO, Solano de. Título: Forum shopping: modo lícito de escolha de jurisdição? 2015. 203 p. Dissertação (Mestrado em Direito) - Faculdade de Direito da Universidade de São Paulo, São Paulo, 2015.

A doutrina internacional costuma conceituar o forum shopping como a escolha da jurisdição mais favorável ao demandante, nas hipóteses em que haja competências internacionais concorrentes. Toda uma série de fenômenos trazidos com a globalização (sejam eles políticos, sociais ou econômicos) repercute concretamente no direito internacional privado, ampliando as possibilidades de litígios em escala mundial, e trazendo consigo diversas inquietações. O exercício dessa mesma opção em jurisdições estrangeiras, ao longo do tempo, tem levado a doutrina e a jurisprudência internacional a qualificar o forum shopping quer como um abuso do direito processual quer como um direito potestativo legítimo do demandante. A proposta deste trabalho é a análise do fenômeno no âmbito do direito internacional privado, com enfoque nos efeitos de ordem material e processual que refletem nos conflitos instaurados no Brasil e no estrangeiro, analisando-se casos de repercussão internacional.

Palavras-chave: Conflito de jurisdições - Forum shopping - Abuso do direito. 


\begin{abstract}
CAMARGO, Solano de. Título: Forum shopping: lawful mode of choice of jurisdiction? 2015. 203 p. Dissertation (Master in Law) - Faculdade de Direito da Universidade de São Paulo, São Paulo, 2015.

The international doctrine usually conceptualizes forum shopping as the choice of jurisdiction more favorable to the plaintiff, in the hypothesis where there is international concurrent jurisdictions. A whole series of phenomena brought with the globalization (whether political, social or economic) reverberate concretely in the private international law, expanding the possibilities of disputes in a worldwide scale, bringing with itself several concerns. The exercise of such option in foreign jurisdictions, through out the time, has led the international doctrine and jurisprudence to qualify the forum shopping either as an abuse of procedural right either as a legitimate potestative right of the plaintiff. The purpose of this work is the analysis of the phenomenon in the context of private international law, focusing on the effects of substantive and procedural order that reflect in the conflicts filed in Brazil and in abroad, analyzing the cases of international repercussions.
\end{abstract}

Keywords: Conflict of jurisdictions - Forum shopping - Abuse of law. 


\section{SUMÁRIO}

\section{PARTE I}

INTRODUÇÃO

CAPÍTULO I - CONSIDERAÇÕES GERAIS ........................................................... 19

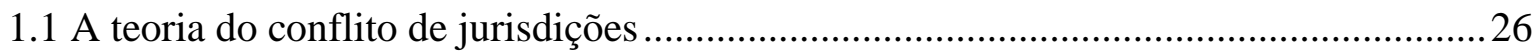

1.2 Conflito de jurisdições e direito internacional privado...............................................2

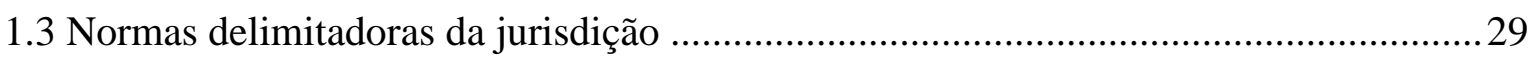

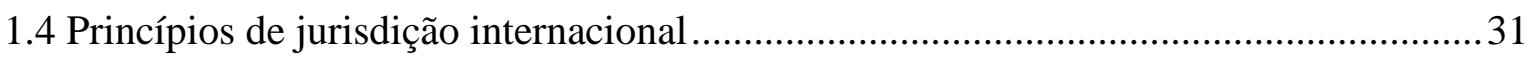

1.4.1 Princípio positivos de incidência e reconhecimento da jurisdição internacional ........38

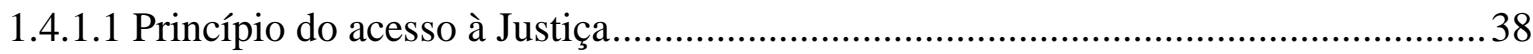

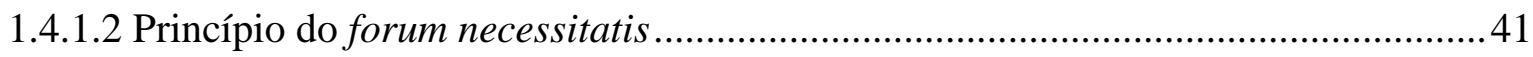

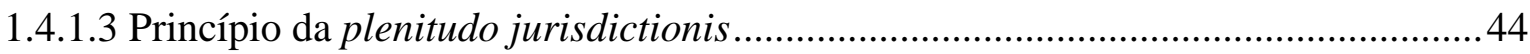

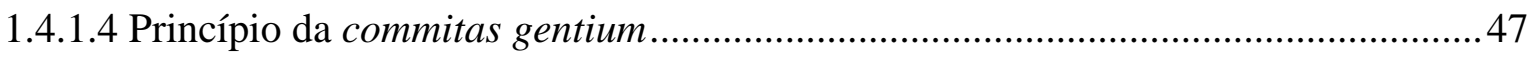

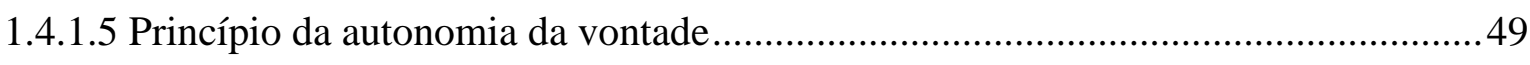

1.4.2 Princípios negativos de incidência e reconhecimento da jurisdição internacional ......53

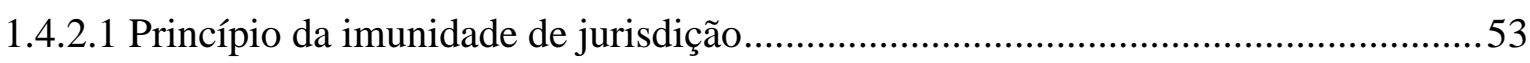

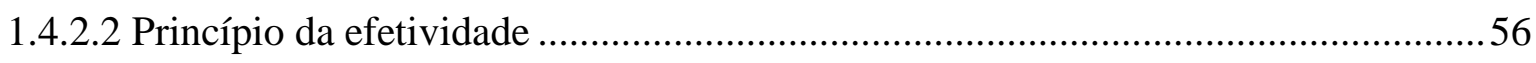

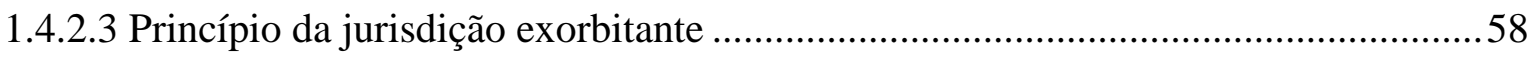

1.5 Forum game: a teoria dos jogos e a racionalidade na escolha da jurisdição

mais favorável 64

CAPÍTULO 2 - FUNDAMENTOS DO FORUM SHOPPING NO COMMON LAW ....... 73

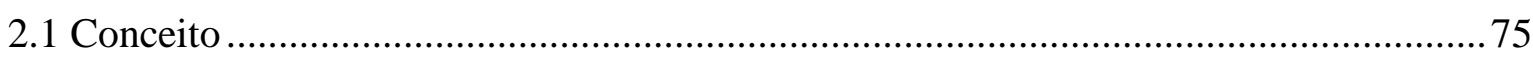

2.2 Forum shopping e forum non conveniens na tradição do common law ......................... 78

2.2.1 Forum shopping como manipulação do local do litígio ............................................. 79

2.2.2 Forum shopping como legítimo exercício de direito .............................................. 82

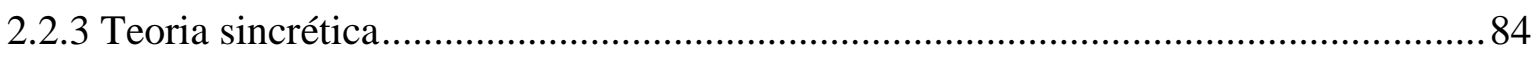

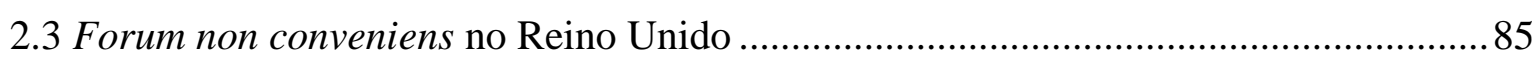

2.3.1 As origens na Escócia, desde o forum non competens ao "forum mais apropriado" .86

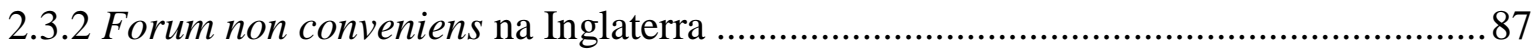

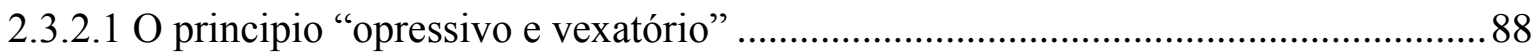


2.3.2.2 A abordagem do foro mais adequado

2.3.2.3 O sistema Bruxelas-Lugano de definição de competência internacional e seus efeitos no Reino Unido.

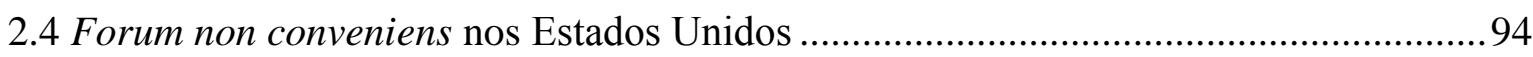

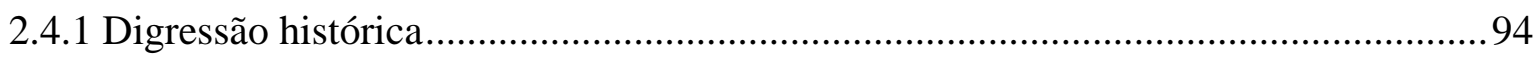

2.4.2 Gilbert and Koster e a doutrina contemporânea .......................................................95

2.4.3 Piper Aircraft e a atual posição da Suprema Corte ………..........................................98

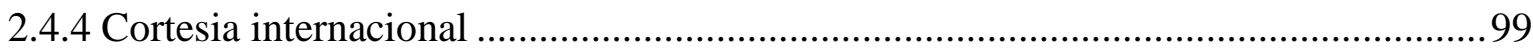

2.5 Forum shopping no âmbito do direito da União Europeia .......................................... 103

\section{PARTE II}

\section{CAPÍTULO 3 - FORUM SHOPPING NO DIREITO INTERNACIONAL}

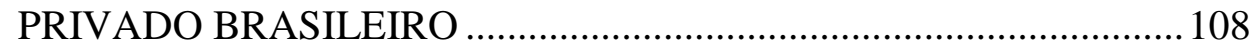

3.1 Breve síntese evolutiva da competência internacional da Justiça brasileira................. 108

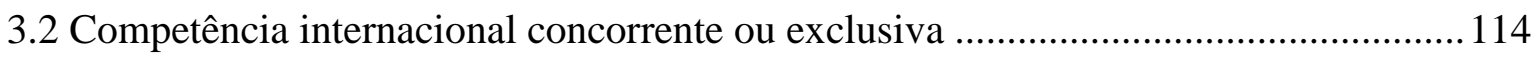

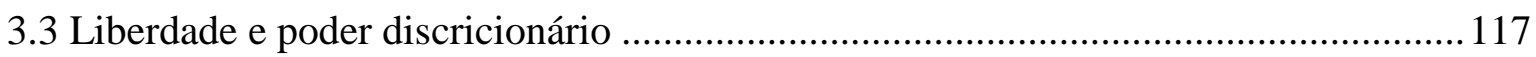

3.4 Manifestação do forum shopping em seus diversos níveis no direito

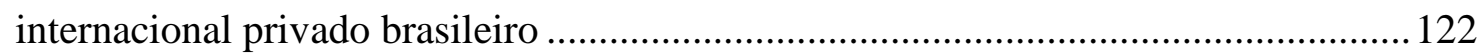

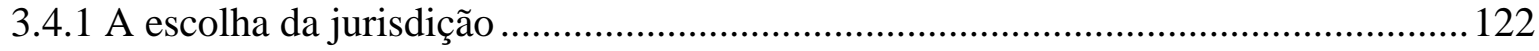

3.4.1.1 Primeiro nível de forum shopping: escolha da jurisdição para aplicação do método de direito internacional privado

3.4.1.2 Segundo nível de forum shopping: escolha da jurisdição e do direito aplicável pela vontade das partes

3.4.1.3 Terceiro nível de forum shopping: coisa julgada estrangeira ............................... 129

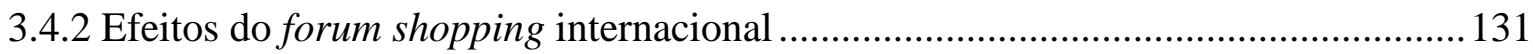

3.4.2.1 Conexão e litispendência internacional: o Protocolo de Las Leñas......................... 134

3.4.2.2 A prevenção de foro internacional: Protocolo de Ouro Preto .................................. 138

3.4.2.3 Forum shopping em matéria contratual: o Protocolo de Buenos Aires .................. 140

3.5 Direito subjetivo e abuso do direito no forum shopping ............................................. 144

$3.6 \mathrm{O}$ abuso do direito no ordenamento jurídico brasileiro .............................................. 145

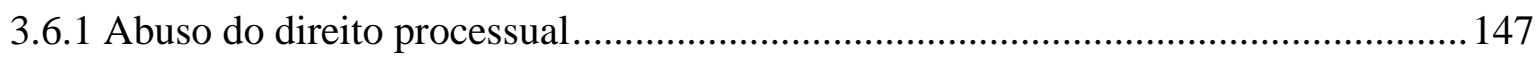

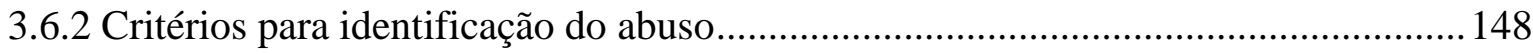

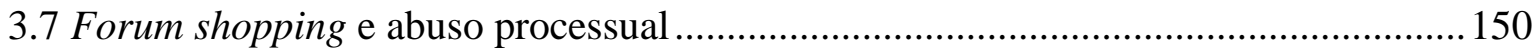


3.7.1 Dever de lealdade.

3.7.2 Uso do processo para atingimento de objetivo ilegal

CAPÍTULO 4 - FORUM SHOPPING E ABUSO DO DIREITO PROCESSUAL -

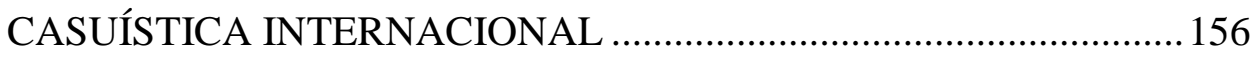

4.1 O torpedo italiano: conexão de processos no âmbito da União Europeia .................... 156

4.2 O libel tourism inglês: defamation laws e liberdade de expressão ............................... 163

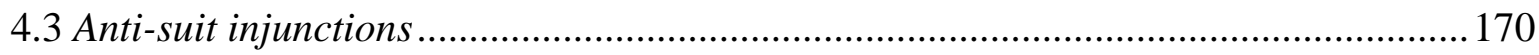

CONCLUSÕES E O FUTURO DO FORUM SHOPPING ........................................ 177

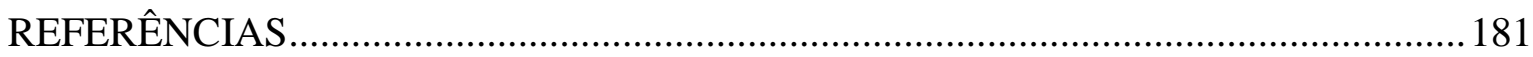




\section{PARTE I}




\section{INTRODUÇÃO}

Os diversos aspectos relacionados à escolha da jurisdição mais favorável ao demandante (escolha essa denominada de forum shopping pela doutrina internacional) ainda não mereceu a devida atenção dos estudiosos brasileiros, embora amplamente estudada e debatida na tradição do common law e no direito da União Europeia.

Toda uma série de fenômenos trazidos com a globalização (sejam eles políticos, sociais ou econômicos) repercutem concretamente no direito internacional privado ${ }^{1}$, ampliando as possibilidades de litígios em escala mundial, e trazendo consigo diversas inquietações.

A delimitação da competência internacional da jurisdição brasileira ${ }^{2}$, pelos artigos 21 a 25 do Novo Código de Processo Civil (NCPC) $)^{3}$ e 12 e 15 da Lei de Introdução às Normas do Direito Brasileiro (LINDB) ${ }^{4}$, admite a possibilidade de que o demandante estabeleça uma linha de atuação processual envolvendo, à sua escolha, tanto a jurisdição estrangeira quanto a brasileira, ou mesmo ambas combinadas, sobrepostas, ou até mesmo uma em oposição à outra (art. 24 do NCPC).

O exercício dessa mesma opção em jurisdições estrangeiras, ao longo do tempo, tem levado a doutrina e a jurisprudência internacional a qualificar o forum shopping quer como um abuso do direito processual $^{5}$, quer como um direito potestativo legítimo do

\footnotetext{
${ }^{1}$ FERNÁNDEZ ARROYO, Diego P. El derecho internacional privado en el inicio del siglo XXI. Caderno da Pós-Graduação em Direito - PPGDir./UFRGS, v. 1, n. 2, p. 209-226, set. 2003.

2 Considera-se a expressão "competência de jurisdição", em princípio, imprópria, conforme a definição de Liebman de que a competência é a "medida da jurisdição" (LIEBMAN, Enrico Tullio. Manual de direito processual civil. Palmas: Intelectus, 2003. v. 1, p. 61). Porém, essa expressão parece ser a mais utilizada, "à falta de outra melhor", significando "o conjunto de atividades jurisdicionais cujo exercício é atribuído a cada organismo judiciário, ou sistema integrado e autônomo de órgãos (Justiças)" (CINTRA, Antônio Carlos de Araújo; GRINOVER, Ada Pellegrini; DINAMARCO, Candido Rangel. Teoria geral do processo. 30. ed. São Paulo: Malheiros, 2014. p. 43). Ver também: CARNEIRO, Athos Gusmão. Jurisdição e competência: exposição didática, área do direito processual civil. 13. ed. São Paulo: Saraiva, 2004. p. 79.

${ }^{3}$ Lei n. 13.105, de 15 de março de 2015. No CPC de 1973, ainda vigente quando da elaboração deste trabalho, são os artigos 88 a 90.

${ }^{4}$ Decreto-Lei n. 4.657, de 4 de setembro de 1942.

${ }^{5}$ MALOY, Richard. Forum shopping? What's wrong with that? Quinnipiac Law Review, Bridgeport, Conn., Law Review Association of the Quinnipiac College School of Law, v. 24, p. 25-62, 2005-2006; CHUANG, Chester S. Offensive venue: the curious use of declaratory judgment to forum shop in patent litigation. The George Washington Law Review, v. 80, No. 4, p. 1.065-1.114, June 2012; e ZYWICKI, Todd J. Is Forum shopping corrupting America's Bankruptcy Courts? The Georgetown Law Journal, Washington, DC, v. 94, No. 4, p. 1.141-1.195, April 2006.
} 
demandante $^{6}$. Esse debate, por conta da nova realidade do direito internacional privado $^{7}-$ trazida pela globalização econômica, universalização das comunicações e a ampliação dos blocos regionais - parece longe de acabar.

A proposta deste trabalho é a análise desse fenômeno pela óptica do direito internacional privado, analisando-se os reflexos processos e de direito material ${ }^{8}$ que incidem nos litígios propostos nos tribunais brasileiros e no exterior.

Para a correta compreensão do tema, será necessário o estudo das ocorrências do forum shopping no âmbito do direito internacional, ficando desde já excluído o estudo de sua ocorrência no âmbito exclusivamente doméstico, isto é, como uma opção entre duas ou mais competências internas.

Assim, são fixadas as seguintes premissas de estudo: (a) análise teórica (précontenciosa) da jurisdição a ser utilizada pelo demandante (princípio da autonomia da vontade, expresso em cláusulas de eleição de foro ou de corte arbitral estrangeiros ${ }^{9}$, ou pela previsão legal que admita jurisdições concorrentes ${ }^{10}$ ); (b) nos efeitos dos processos judiciais, administrativos ou arbitrais oriundos de sua respectiva tramitação (com especial atenção nos fenômenos de litispendência ou conexão internacional ${ }^{11}$ ); e, finalmente, (c) na percepção das consequências da coisa julgada internacional no Brasil (dentro do cenário da teoria do conflito de jurisdições). ${ }^{12}$

${ }^{6}$ JUENGER, Friedrich K. What's wrong with forum shopping? Sydney Law Review, v. 16, No. 1, p. 5-13, Mar. 1994; CLERMONT, Kevin M.; EISENBERG, Theodore. Exorcising the evil of forum shopping. Cornell Law Review, v. 80, No. 6, p. 1.507-1.535, Sept. 1995; e ALGERO, Mary Garvery. In defense of forum shopping: a realistic look at selecting a venue. Nebraska Law Review, Lincoln, College of Law, University of Nebraska, v. 78, p. 79-112, 1999.

${ }^{7}$ HÖFFE, Otfried. A democracia no mundo de hoje. Tradução de Tito Lívio Cruz Romão. São Paulo: Martins Fontes, 2005. p. 50.

${ }^{8}$ BEDAQUE, José Roberto dos Santos. Direito e processo: influência do direito material sobre o processo. São Paulo: Malheiros, 1995.

${ }^{9}$ Ver, por todos: STRENGER, Irineu. Autonomia da vontade em direito internacional privado. São Paulo: Revista dos Tribunais, 1968. p. 193.

${ }^{10}$ REYDAMS, Luc. Universal jurisdiction: international and municipal legal perspective. New York: Oxford University Press, 2003. p. 43; e MOSCHEN, Valesca Raizer Borges; SOUZA, Leandro Eloy. A solução europeia para a competência internacional. Revista de Processo, São Paulo, Revista dos Tribunais, v. 36, n. 192, p. 307-335, fev. 2011.

${ }^{11}$ MOREIRA, José Carlos Barbosa. Problemas relativos a litígios internacionais. In: Temas de direito processual: quinta série. São Paulo: Saraiva, 1994. p. 139; e GAILLARD, Emmanuel (Ed.). Anti-suit injunctions in international arbitrations. IAI Seminar, Paris, November 21, 2003. Huntington, NY: Juris Publishing; Bern: Staempfli, 2005. p. 58.

12 JATAHY, Vera Maria Barrera. Do conflito de jurisdições: a competência internacional da justiça brasileira. Rio de Janeiro: Forense, 2003. p. 36; CARDOSO, Oscar Valente. Litispendência e coisa julgada 
Em síntese, o tema é delimitado pelo estudo de cada uma dessas possíveis vias de análise, dentro do gradiente que parte do direito potestativo do demandante, até os limites do abuso do direito processual. ${ }^{13}$

Em linhas gerais, serão essas as matérias versadas na dissertação de mestrado que, ao final, tentará apontar uma possível sistematização do fenômeno.

O pouco interesse com que a doutrina brasileira analisou o fenômeno do forum shopping, o mais das vezes fez com que o tema não merecesse um estudo mais aprofundado ou sistematizado. E, mesmo quando feita a abordagem, tal se deu de maneira pejorativa, associando sua incidência (e consequente proibição) necessariamente com a de um instituto exclusivo do common law, o denominado forum non conveniens ${ }^{14}$ (que, de um modo geral, tem sido qualificado como a faculdade de o julgador optar livremente por não conhecer do litígio, sob o argumento de que outra jurisdição teria melhores condições de julgar aquele feito).

A doutrina brasileira não tem explorado a ocorrência do forum shopping em ordenamentos de tradição romano-germânica, como, por exemplo, no âmbito da União Europeia ou mesmo do Mercosul, espaços em que o forum non conveniens pode ser qualificado como uma instituição desconhecida (portanto, desde já parece haver uma dissociação entre o forum shopping e o forum non conveniens). Na União Europeia, a atual regulação sobre a competência internacional visou expressamente a coibir abusos processuais decorrentes da propositura de ações conexas ou litispendentes em jurisdições concorrentes $^{15}$, sem a possibilidade de aplicação da doutrina do forum non conveniens,

nos processos dos tribunais internacionais. Revista Dialética de Direito Processual, São Paulo, n. 118, p. 56-70, jan. 2013; e GUERRA, Marcel Vitor de Magalhães; MOSCHEN, Valesca Raizer Borges. Influências do common law no Brasil. Questão relacionada ao forum shopping: afinal, é possível a um juiz nacional derrogar sua competência internacional com base na doutrina estrangeira do forum non conveniens?. In: ENCONTRO NACIONAL DO CONPEDI: Direitos fundamentais e transdisciplinariedade, 19., 2010, Fortaleza, CE. Anais... Florianópolis: Fundação Boiteux, 2010. p. 3.7073.716.

13 TUCCI, José Rogério Cruz e. Repressão ao dolo processual: o novo art. 14 do CPC. Revista Jurídica, Porto Alegre, Notadez, v. 50, n. 292, p. 15-27, 2002.

14 JATAHY, Vera Maria Barrera, Do conflito de jurisdições: a competência internacional da justiça brasileira, cit., p. 37.

${ }^{15}$ Ver Regulamento (UE) 1.215/2012 relativo à competência judiciária, ao reconhecimento e à execução de decisões em matéria civil e comercial. No considerando n. 22, o legislador europeu manifestou expressamente sua preocupação quanto ao possível forum shopping abusivo: "Todavia, a fim de reforçar a eficácia dos acordos exclusivos de eleição do foro competente e de evitar táticas de litigação abusivas, é necessário prever uma exceção à regra geral de litispendência, a fim de lidar de forma satisfatória com uma 
muito embora essa mesma regulação tenha causado ao menos um efeito colateral indesejado (os denominados torpedos). O mesmo tratamento europeu foi adotado pelo Mercosul, no Protocolo de Las Leñas (art. 22, $2^{\mathrm{a}}$ parte).

Dessa forma, numa primeira justificativa quanto à escolha do tema, parece decorrer da necessidade de se separar o fenômeno do forum shopping da doutrina do forum non conveniens, ante a possível autonomia entre os temas. Em outras palavras, há de se averiguar a ocorrência de forum shopping independentemente de o sistema jurídico em questão admitir ou não o forum non conveniens. ${ }^{16}$

Outro ponto importante que parece justificar a escolha do tema é a invocação do forum shopping pela jurisprudência brasileira com os mais diversos e criativos significados que, muito embora resvalem na questão da escolha do proponente quanto ao local em que a demanda será ajuizada, afastam-se da conceituação geral do direito internacional privado ${ }^{17}$, e muitas vezes se referem exclusivamente a questões de competência doméstica.

Portanto, como uma segunda justificativa para o tema, a aparente confusão entre os conceitos de jurisdição e competência parece fazer com que o uso do termo forum shopping pela jurisprudência brasileira esteja rapidamente ganhando contornos diferentes e possivelmente equivocados, quando comparados com a conceituação original do fenômeno.

Por fim, justifica-se a escolha do tema pela sua importância dentro da atual conjuntura e dinamicidade da economia global: é cada vez mais comum que as grandes empresas transnacionais se façam presentes em um sem-número de Estados, tendo seu

situação particular no âmbito da qual poderão ocorrer processos concorrentes. Trata-se da situação em que é demandado um tribunal não designado num acordo exclusivo de eleição do foro competente, e o tribunal designado é demandado subsequentemente num processo com a mesma causa de pedir e com as mesmas partes. Nesse caso, o tribunal demandado em primeiro lugar deverá ser chamado a suspender a instância logo que o tribunal designado seja demandado e até que este declare que não é competente por força do acordo exclusivo de eleição do foro competente. Isto destina-se a, numa tal situação, dar prioridade ao tribunal designado para decidir da validade do acordo e em que medida o acordo se aplica ao litígio pendente. O tribunal designado deverá poder prosseguir a ação independentemente de o tribunal não designado já ter decidido da suspensão da instância."

${ }^{16}$ Como será visto oportunamente, o instituto do forum non conveniens, típico da tradição do common law, parece estar ligado (num grau de oposição direta) ao anti-suit injuction.

${ }_{17}$ Os qualificativos utilizados são os mais diversos. Por exemplo: no AI n. 70054946471 (TJRS), forum shopping foi descrito como "uma burla ao juiz natural"; no AI n. 2011.002.05-9/0001-00 (TJMS), como “um foro aleatório"; no AI n. 20120082535 (TJSC), como "o direito potestativo do autor". 
comando societário diluído nos mais diversos sistemas financeiros internacionais, e com diferentes nacionalidades à frente das posições de gestão, fazendo com que os critérios clássicos definidores da sede da pessoa jurídica tornem-se pouco úteis ${ }^{18}$ para se definir a jurisdição dos conflitos por regras legais pré-determinadas.

Em segundo lugar, os conflitos oriundos da internet ${ }^{19}$, ou, em terceiro lugar, da violação de patentes em escala global ${ }^{20}$, tem gerado um sem-número de possibilidades de instauração de litígios, na medida que os atos ilícitos cometidos na rede mundial de computadores (por exemplo, oriundos da difamação) ou na apropriação de invenções ou de marcas podem ser, sem exagero, verdadeiramente universais $^{21}$. Assim, como terceira $e$ última justificativa para a escolha do tema, a análise do processo civil como jogo ${ }^{22}$, ou como guerra $^{23}$, parece ter assumido proporções globais.

Em resumo, a análise das diferentes relações jurídicas contemporâneas, dentro de uma realidade multifacetada, tem estabelecido uma ampla gama de possibilidades de escolha de jurisdições, por quaisquer das partes, como nunca dantes. O direito internacional privado nasceu do desenvolvimento das relações de ordem privada entre os diferentes povos $^{24}$, sendo necessário decidir, nessas mesmas relações particulares, qual dentre as jurisdições passíveis de serem escolhidas é a competente para conhecer das questões e dizer-lhes o direito aplicável (o qual, por sua vez, tanto poderá ser a lex fori

\footnotetext{
${ }^{18}$ A regra geral que define o domicílio da pessoa jurídica está contida no artigo 75 do Código Civil de 2002, sendo esse o lugar de sua sede social ou estatutária. Celso Agrícola Barbi expõe que dentro dos princípios que levam os Estados a limitar sua jurisdição, deve-se interpretar o parágrafo $2^{\circ}$ do artigo 75 como aplicável às demandas oriundas de negócio jurídico das próprias agências, filiais ou sucursais, pois só essas causas é que podem interessar à ordem jurídica do país (BARBI, Celso Agrícola. Comentários ao Código de Processo Civil: Lei n. 5.869, de 11 de janeiro de 1973: arts. $1^{\circ}$ a 153. 14. ed. rev. e atual. por Bernardo Pimentel Souza. Rio de Janeiro: Forense, 2010. v. 1, p. 241). Ainda sobre o tema: RODAS, João Grandino. Evolução do liame entre sociedade comercial e estado. Tese (Professor Titular) - Faculdade de Direito da Universidade de São Paulo, São Paulo, 1993.

${ }^{19}$ KOHL, Uta. Jurisdiction and the internet: regulatory competence over online activity. Cambridge; New York: Cambridge University Press, 2007. p. 159; e HÖRNLE, Julia. Cross-border internet dispute resolution. Cambridge, UK; New York: Cambridge University Press, 2009. p. 91.

${ }^{20}$ LÓPEZ-TARRUELLA MARTÍNEZ, Aurelio. Litigios transfronterizos sobre derechos de propiedad industrial e intelectual. Madrid: Dykinson, 2008. p. 37.

21 JAYME, Erik. O direito internacional privado do novo milênio: a proteção da pessoa humana face à globalização. Cadernos do Programa de Pós-Graduação em Direito - PPGDir./UFRGS, v. 1, n. 1, p. 133, mar. 2003.

${ }^{22}$ CALAMANDREI, Piero. Il processo come giuoco. Rivista de Diritto Processuale, Padova, Cedam, v. 5, n. 1, p. 24, 1950.

23 MOREIRA, José Carlos Barbosa. Duelo e processo. Revista de Processo, São Paulo, Revista dos Tribunais, v. 28, n. 112, p. 177-185, out./dez. 2003.

${ }^{24}$ STRENGER, Irineu. Curso de direito internacional privado. Rio de Janeiro: Forense, 1978. p. 6.
} 
quanto uma lei estranha ao foro ${ }^{25}$. E essa análise, após definida a jurisdição em que tramitará a demanda pela escolha do autor (forum shopping), será qualificada como um exercício legítimo do direito potestativo (opção processualmente lícita) ou como uma forma de um abuso do direito processual praticado contra o réu.

No desenvolvimento deste trabalho, optar-se-á pela análise do forum shopping pela ótica dos princípios que regem a jurisdição: princípios positivos, que favorecem ou permitem a propositura de demandas em jurisdições estrangeiras, ou princípios negativos, que as impedem.

Esse gradiente de opções não parece ficar restrito exclusivamente (a) à análise da jurisdição que possa garantir a melhor tutela jurisdicional ao forum shopper (o chamado "bem da vida"), ou (b) à incidência da melhor lei aplicável ao conflito, segundo as conexões estabelecidas pelas regras de direito internacional privado do foro, mas também parece levar em conta resultados indiretos, tal como (c) o efeito processual que o litígio proposto em um Estado específico possa gerar em outro litígio, em trâmite em um segundo ou terceiro Estado (litispendência ou conexão internacional), (d) mas também há que se levar em conta o custo envolvido na condução dos litígios, comparativamente em diversos Estados e, finalmente, (e) o prazo para resolução das lides, também comparativamente em jurisdições concorrentes. $^{26}$

Muito embora essa análise majoritariamente econômica mereça uma interpretação jurídica baseada na legitimidade da opção (como um direito potestativo do autor) ou em sua temeridade (como abuso processual), a escolha da jurisdição parece interligar-se com a teoria dos jogos, ao levar em conta a opção estratégica - ou tática - que melhor potencialize o resultado pretendido pelo autor ${ }^{27}$, este sim, de cunho econômico. Porém, para maximizar esse mesmo resultado, o demandante deverá levar em conta as decisões

${ }^{25}$ SOARES, Guido Fernando Silva. A competência internacional do judiciário brasileiro e a questão da autonomia da vontade das partes. In: BAPTISTA, Luiz Olavo; CASELLA, Paulo Borba; HUCK, Hermes Marcelo (Coords.). Direito e comércio internacional: tendências e perspectivas: estudos em homenagem ao prof. Irineu Strenger. São Paulo: LTr, 1994. p. 285.

26 "É certo que no processo, como vaticinara Couture, o tempo é algo mais do que ouro: é justiça." (TUCCI, José Rogério Cruz e. Tempo e processo: uma análise empírica das repercussões do tempo na fenomenologia processual (civil e penal). São Paulo: Revista dos Tribunais, 1997. p. 146).

${ }^{27}$ Nicholas Mercuro e Steven Medema afirmam que as relações jurídicas governam a sociedade e afetam diretamente o resultado econômico, alterando a estrutura de incentivos (MERCURO, Nicholas; MEDEMA Steven G. Economics and the Law. Princeton: Princeton University Press, 1997. p. 21). 
que podem ser tomadas pela outra parte, dentro de um contexto estratégico de modelos $\operatorname{complexos}^{28}$, que passará pela possível escolha de uma jurisdição ${ }^{29}$ por qualquer dos litigantes. Dessa maneira, uma breve análise da teoria nos jogos poderá auxiliar na compreensão do fenômeno do forum shopping.

Por fim, analisar-se-á exemplos reconhecidos na doutrina e na jurisprudência estrangeiras, quanto à utilização do forum shopping, a partir da qual se procurará analisar as razões que levaram à escolha do foro a partir da casuística internacional.

${ }^{28}$ DIXIT, Avinash K.; SKEATH, Susan. Games of strategy. 2nd ed. New York: W. W. Norton, 2004. p. 20.

${ }^{29}$ BASSETT, Debra Lyn. The forum game. North Carolina Law Review, Chapel Hill, NC, v. 84, p. 373, 2006. 


\section{CAPÍTULO I - CONSIDERAÇÕES GERAIS}

A sociedade contemporânea tem pressa e clama por resultados imediatos, instantâneos e perceptíveis. O direito internacional privado evolui sob solavancos, colidindo entre as regras de conflito estatais, o desenvolvimento humano e o comércio internacional. ${ }^{30}$

$\mathrm{Na}$ realidade social contemporânea emergem enormes desafios. Considerando-se a economia, a ciência, a medicina e a cultura, além de outros fatores como as correntes migratórias, os problemas ambientais e até mesmo o terrorismo, percebe-se a necessidade de ações que não se atêm às fronteiras entre os Estados ${ }^{31}$. A criatividade humana, individual ou coletiva, e suas respectivas crises episódicas, tem impulsionado a sociedade em avanços significativos.

Em 1861, Savigny saudava que quanto mais numerosas e ativas fossem as relações entre os povos, menos poderia se impor aos juízes de um Estado que aplicassem exclusivamente seu próprio direito nacional. Todos deveriam ser iguais perante os tribunais: nacionais e estrangeiros. E se essa igualdade fosse concretizada, não somente a justiça seria acessível a todos, indistintamente, mas também nos conflitos de leis "a decisão tomada sobre a relação jurídica seria sempre a mesma, qualquer que fosse o Estado em que a sentença tivesse sido pronunciada". 32

Embora a profecia de Savigny pareça distante, é bem verdade que grande parte dos sistemas jurídicos tem dado guarida às pretensões processuais dos estrangeiros. E dentro desse arcabouço, tem sido obra dos juristas estabelecer os mecanismos mínimos para que as especificidades de cada sistema jurídico normativo, compreendido dentro de seu próprio sistema, sejam respeitadas ou readaptadas à evolução da sociedade, dentro da gradação valorativa da denominada ordem pública universal. ${ }^{33}$

\footnotetext{
${ }^{30}$ JAYME, Erik. Formação progressiva do direito internacional privado por parte dos juízes: a experiência americana e alemã até 1986. Cadernos do Programa de Pós-Graduação em Direito - PPGDir./UFRGS, v. 1, n. 1, p. 69-93, mar. 2003.

${ }^{31}$ HÖFFE, Otfried, A democracia no mundo de hoje, cit., p. 7.

${ }^{32}$ SAVIGNY, Friedrich Carl von. Sistema do direito romano atual. Tradução de Ciro Mioranza. Ijuí, RS: Unijuí, 2004. p. 49.

${ }^{33}$ DOLINGER, Jacob. A evolução da ordem pública no direito internacional privado. Rio de Janeiro: Renovar, 1979. p. 13.
} 
Se a sociedade contemporânea tem pressa, do ponto de vista jurídico, a premência de resultados traduz-se na busca da efetividade dos mecanismos judiciais. São as tendências voltadas à instrumentalidade do processo que traduzem sua efetividade. ${ }^{34}$

Como em várias outras situações da vida cotidiana, a efetividade processual pode, num determinado momento, assunto ou circunstância, estar no estrangeiro. E toda a decorrência jurídica que deriva dessa escolha pertine ao estudo do direito internacional. ${ }^{35}$

Forum shopping foi a nomenclatura utilizada pelos juristas do common law para definir a escolha, dentre várias jurisdições passíveis de serem exercitadas, como sendo aquela de preferência do demandante, levando-se em conta as mais diversas premissas.

A escolha da melhor jurisdição, conforme aponta a doutrina estrangeira, não parece ser uma espécie de zona desmilitarizada (ou neutra), mas, ao contrário, parece compor um palco de grandes paixões, quer em defesa, quer em condenação ao forum shopping. ${ }^{36}$

O tema da escolha da jurisdição mais favorável e as questões que o circundam tem sido debatido há várias décadas no exterior, muitas vezes de maneira eloquente, não tendo merecido o mesmo tratamento pela doutrina brasileira, carecendo de uma sistematização.

Essa é a proposta do presente trabalho.

De início, parece adequado inserir o forum shopping no âmbito da jurisdição, ao invés da competência ${ }^{37}$, na medida que a aplicação do instituto refere-se, o mais das vezes, à propositura de demandas em jurisdições outras que não a de qualquer das partes, bem

\footnotetext{
${ }^{34}$ Ver, por todos: DINAMARCO, Cândido Rangel. A instrumentalidade do processo. 15. ed. São Paulo: Malheiros, 2013.

${ }^{35}$ GOLDSCHMIDT, Werner. Sistema e filosofía del derecho internacional privado. 2. ed. Buenos Aires: Ediciones Jurídicas Europa-América, 1952. v. 3, p. 68.

${ }^{36}$ OPESKIN, Brian. The price of forum shopping: a reply to Professor Juenger. Sydney Law Review, v. 16, No. 1, p. 14-27, Mar. 1994.

37 MALOY, Richard, Forum shopping? What's wrong with that?, cit., p. 25-62; CHUANG, Chester S., Offensive venue: the curious use of declaratory judgment to forum shop in patent litigation, cit., p. 1.0651.114; ZYWICKI, Todd J., Is Forum shopping corrupting America's Bankruptcy Courts?, cit., p. 1.1411.195; JUENGER, Friedrich K., What's wrong with forum shopping?, cit., p. 5-13; CLERMONT, Kevin M.; EISENBERG, Theodore, Exorcising the evil of forum shopping, cit., p. 1.507-1.535; e ALGERO, Mary Garvery, In defense of forum shopping: a realistic look at selecting a venue, cit., p. 79-112.
} 
como os efeitos daí decorrentes (como a litispendência, a conexão, a coisa julgada internacional e o processo de recepção de seus efeitos no estrangeiro).

De uma forma diversa da utilizada nos Estados do common law e da União Europeia, parte expressiva da jurisprudência brasileira tem usado o termo forum shopping para as hipóteses em que um demandante - usualmente brasileiro - tenha duas ou mais opções geográficas a sua disposição, igualmente dentro do território brasileiro, como possíveis foros competentes. Especificamente, a jurisprudência nacional ${ }^{38}$ tem apontado como exercício de forum shopping as opções entre diversos foros nacionais potencialmente competentes, como, por exemplo, nos casos de relação de consumo. ${ }^{39}$

Porém, nesse caso específico, trata-se de escolhas de competência, e não de jurisdição.

Jurisdição, para Chiovenda, é a função estatal que tem como propósito a atuação da vontade concreta da lei, por meio de substituição, pela atividade de seus órgãos públicos, da atividade de particulares ou de outros órgãos públicos, "já no afirmar a existência da vontade da lei, já no torná-la, praticamente efetiva" ${ }^{40}$. Dinamarco aponta que o conceito moderno de jurisdição é uma expressão de poder estatal, uno e indivisível; é a capacidade de decidir e impor decisões. ${ }^{41}$

Todos os juízes exercem a jurisdição, mas a exercem numa certa medida, dentro de determinados limites. No dizer de Athos Gusmão Carneiro, são tais juízes “competentes" somente para processar e julgar determinadas causas. A competência, assim, é a medida da

\footnotetext{
${ }^{38}$ Por exemplo: AI n. 70054370028 (TJRS). Nesse e em mais de 400 precedentes, encontra-se o excerto: "Por outro lado, ainda mais importante, a escolha do Estado da Federação em que ajuizar a demanda poderá refletir burla do princípio do juiz natural, pois, conhecendo o advogado a orientação jurisprudencial dos juízes e desembargadores de um determinado Estado, poderia ele estar inclinado a escolher o foro mais conveniente para o ajuizamento da demanda (fenômeno esse que, nos Estados de Common Law, é conhecido pela expressão forum shopping)". Também em análoga posição: AgR n. 7.166 (TJMS); AI n. 912.335-7 (TJPR); etc.

${ }^{39}$ Por ser considerada a parte hipossuficiente da relação jurídica de consumo, o consumidor tem a faculdade de escolher o foro do lugar onde ocorreu ou deva ocorrer o dano, ou do seu próprio domicílio, conforme a norma jurídica disposta nos artigos 93, I, e 101, I, do CDC.

${ }^{40}$ CHIOVENDA, Giuseppe. Instituições de direito processual civil. Tradução da 2. ed. italiana por J. Guimarães Menegale; acompanhada de notas pelo prof. Enrico Tullio Liebman. São Paulo: Saraiva, 1943. v. 1, p. 15.

${ }^{41}$ DINAMARCO, Cândido Rangel. Litisconsórcio. 5. ed. São Paulo: Malheiros, 1997. p. 41.
} 
jurisdição ${ }^{42}$. Liebman se referiu à competência como a quantidade de jurisdição cujo exercício é atribuído a cada órgão, ou seja, a "medida de jurisdição"43. A competência determina em que casos e com relação a que controvérsias tem cada órgão em particular o poder de emitir provimentos, ao mesmo tempo que delimita abstratamente o conjunto de controvérsias que lhe são atribuídas. ${ }^{44}$

Dessa forma, ao optar por propor uma ação no Brasil, ao invés da França ou do Japão, na hipótese em que tenha tal prerrogativa, estará o demandante optando pela jurisdição brasileira, ao invés da jurisdição francesa ou japonesa, e tal prerrogativa (e seus efeitos) interessa ao direito internacional privado. Via de consequência, tendo escolhido qualquer dessas jurisdições, e lhe sendo possível optar por dois ou mais juízos internos (tais como a paulista ou a carioca, no caso brasileiro; de Paris ou Lyon, no caso francês; ou de Tóquio ou Yokohama, no caso japonês), estará o demandante optando pelo foro dentro de diversas competências internas (e não de jurisdição, que é una em cada um dos Estados), cujo escopo está no âmbito do processo civil interno de cada Estado.

Qualquer eventual confusão entre essas atividades estatais (jurisdição e competência) desaparece, porém, quando se coloca a questão na análise do poder do Estado, como faz Cândido Dinamarco. Inerente à própria existência do Estado, o poder representa a capacidade que ele tem de impor as suas decisões, sendo exercido em conformidade com os objetivos específicos que pretenda alcançar. Destarte, a jurisdição, a administração e a legislação representam as diversas expressões do mesmo poder, diferenciando-se, pois, não ontologicamente, mas apenas em razão das funções exercidas pelo Estado. Vale dizer, a diferença entre elas reside na variedade de funções "que o Estado tem por suas e que projetam reflexos de suas próprias peculiaridades na forma, características e disciplina positiva do exercício do poder enquanto voltado a cada uma delas". 45

${ }^{42}$ CARNEIRO, Athos Gusmão, Jurisdição e competência: exposição didática, área do direito processual civil, cit., p. 61.

${ }^{43}$ LIEBMAN, Enrico Tullio, Manual de direito processual civil, cit., v. 1, p. 55.

${ }^{44}$ José Roberto dos Santos Bedaque afirma que os órgãos jurisdicionais são dotados de idênticos poderes para o pleno exercício da função que lhes foi atribuída, de maneira que a competência não representa a quantidade de jurisdição conferida a cada órgão, mas sim os limites impostos ao exercício válido e regular do poder jurisprudencial. A competência legitima o poder, pelo órgão jurisdicional, em processo concretamente considerado (BEDAQUE, José Roberto dos Santos. Competência: aspectos teóricos e práticos. Revista do Advogado, São Paulo, AASP, v. 25, n. 84, p. 91, dez. 2005).

${ }^{45}$ DINAMARCO, Candido Rangel, $A$ instrumentalidade do processo, cit., p. 160. 
O Estado, antes de transferir o poder jurisdicional ${ }^{46}$ aos órgãos que irão exercê-lo, define os seus contornos, o conteúdo e a extensão, em confronto com o de outros Estados que compõem a comunidade internacional. ${ }^{47}$

O Novo Código de Processo Civil regula, em seus artigos 21 a 25, a denominada jurisdição internacional. Arruda Alvim, ao tratar dos artigos 88 e 89 do Código de Processo Civil de 1973 (em vigor até 16 de março de 2015), esclarece que o Estado busca "definir o poder, da jurisdição nacional, e congruentemente a dos estrangeiros, no sentido de saber se uma dada causa está, ou não, submetida à jurisdição nacional; e, em caso positivo, se há jurisdição concorrente das jurisdições estrangeiras, ou se é exclusiva a da jurisdição nacional". 48

A dificuldade em se distinguir jurisdição e competência agrava-se justamente na conceituação de "competência internacional", terminologia que se deve, na visão de Hélio Tornaghi, a uma "convenção tácita" entre os autores do direito internacional privado e do processo civil ${ }^{49}$ durante a maior parte de quase toda a história jurídica do Brasil, alterada apenas com a futura vigência do Novo Código de Processo Civil de 2015. Seja qual tenha sido o elevado propósito que deva ter inspirado os especialistas ao emprego dessa expressão, ou que tenha levado o legislador do Código de Processo Civil brasileiro de 1973 a utilizá-la nos seus artigos 88 e seguintes, é importante observar a advertência de Gaetano Morelli quanto à possível ocorrência de analogias equivocadas ${ }^{50}$ entre jurisdição e competência.

Conforme Mário Guimarães, “a jurisdição é um todo. A competência, uma fração. Pode um juiz ter jurisdição, sem competência. Não poderá ter competência sem ter jurisdição". 51

\footnotetext{
${ }^{46}$ MARCATO, Antonio Carlos. Breves considerações sobre jurisdição e competência. Jus Navigandi, Teresina, ano 7, n. 56, 01 abr. 2002. Disponível em: 〈http://jus.com.br/artigos/2923〉. Acesso em: 20 fev. 2014.

${ }^{47}$ MONACO, Gustavo Ferraz de Campos; JUBILUT, Lilliana Lyra. Direito internacional privado. São Paulo: Saraiva, 2012. p. 50.

${ }^{48}$ ARRUDA ALVIM, José Manual de. Competência internacional. Revista de Processo, São Paulo, Revista dos Tribunais, v. 2, n. 7/8, p. 24, jul./dez. 1977. No mesmo sentido: ARMELIN, Donaldo. Competência internacional. Revista de Processo, São Paulo: Revista dos Tribunais, v. 1, n. 2, p. 131-158, abr./jun. 1976.

${ }^{49}$ TORNAGHI, Helio. Comentários ao Código de Processo Civil: arts. 1 a 153. São Paulo: Revista dos Tribunais, 1974. v. 1, p. 302.

${ }^{50}$ MORELLI, Gaetano. Derecho procesal civil internacional. Buenos Aires: EJEA, 1953. p. 86.

${ }^{51}$ GUIMARÃES, Mário. O juiz e a função jurisdicional. Rio de Janeiro: Forense, 1958. p. 56.
} 
A expressão "competência de jurisdição", portanto, é incorreta ${ }^{52}$, na medida que no dizer de Liebman - competência é a “medida de jurisdição". Porém, essa expressão vem sendo utilizada, como acentuam Cintra, Pellegrini e Dinamarco, na falta de outra melhor. ${ }^{53}$

Em síntese, competência delimita jurisdição. Reconhece-se ao Estado um amplo poder de dizer o direito (juris dictio) que, em princípio, é ilimitado: “[...] es concebible en abstracto que el Estado ejerza ilimitadamente su propia jurisdicción; es decir, que la ejerza respecto de la composición de todas las litis posibles, aun de las que no están en modo alguno vinculadas con él." 54

O conceito de forum shopping, para efeitos deste trabalho, está ligado ao conceito de jurisdição. Especificamente, à escolha da jurisdição mais favorável ao demandante, seja ela nacional ou estrangeira, de acordo com o sentido que é atribuído ao instituto pela doutrina do common law, de onde é originário.

Uma possível explicação para o uso da terminologia forum shopping nas opções de foro dentro do âmbito de uma mesma jurisdição parece advir do uso da expressão nos Estados Unidos. De um modo geral, no âmbito do common law, utiliza-se o conceito de jurisdiction para todo o poder estatal aplicado em sentido amplo e que inclui, inclusive, o conceito de adjudicatory autority e competence. ${ }^{55}$

Como se verá com mais vagar ao longo deste trabalho, o fato de o termo forum shopping ser particularmente utilizado pela doutrina e pela jurisprudência norte-americana para lides estabelecidas exclusivamente no âmbito da jurisdição dos Estados Unidos não parece transmutar o conceito original do instituto, nascido na tradição do Reino Unido, e que leva em conta litígios transnacionais. A organização processual dos Estados Unidos faz com que seus cinquenta Estados possuam normas de direito material e processual

\footnotetext{
52 CARNEIRO, Athos Gusmão, Jurisdição e competência: exposição didática, área do direito processual civil, cit., p. 79.

${ }^{53}$ CINTRA, Antônio Carlos de Araújo; GRINOVER, Ada Pellegrini; DINAMARCO, Cândido Rangel, Teoria geral do processo, cit., p. 237.

${ }^{54}$ MORELLI, Gaetano, Derecho procesal civil internacional, cit., p. 85.

55 'In common law countries, the term 'jurisdiction' is most commonly used to describe the various forms of judicial authority. In civil law countries, the term 'competence' is preferred." (SMIT, Hans. Common and civil law rules of in personam adjudicatory authority: an analysis of underlying policies. International and Comparative Law Quarterly, Cambridge, v. 21, No. 1, p. 335, 1972).
} 
próprias, dentro de seu regime federativo descentralizado, com a possibilidade de julgamentos civis por tribunais de júri ou juízes togados. Além da possibilidade de ocorrer julgamentos nos sistemas estaduais e seus diferentes ordenamentos materiais, existem ainda foros de competência específica e restrita (em razão da matéria), ou genérica e ampla, além da sobreposição de cortes federais e estaduais ${ }^{56}$ para determinados assuntos em comum ${ }^{57}$, além da tradição do civil law no Estado da Luisiana. Assim, a doutrina local se refere à state jurisdiction no mesmo sentido que a tradição processual brasileira e suas raízes romano-germânicas se referem à competência. ${ }^{58}$

Dessa forma, este trabalho parte da premissa de que o forum shopping é um fenômeno que se relaciona ao direito internacional privado e aos conflitos de jurisdições ${ }^{59}$, e não com o direito interno e os decorrentes conflitos de competência, como erroneamente tem sido apontado pela doutrina e jurisprudência brasileiras. ${ }^{60}$

56 SIMOWITZ, Aaron D. A U.S. perspective on forum shopping, ethical obligation, and international commercial arbitration. In: FERRARI, Franco (Ed.). Forum shopping in the international commercial arbitration context. Munich: Sellier European Law Publishers (SELP), 2013. p. 1-21.

${ }^{57}$ Parece haver uma similaridade de conceitos entre jurisdição e competência no vocábulo jurisdiction, de acordo com o direito processual dos Estados Unidos. Sobre o uso indiscriminado do termo "jurisdição", ver: SMIT, Hans. The terms jurisdiction and competence in comparative law. American Journal of Comparative Law, Berkeley, v. 10, No. 1, p. 164-169, 1961.

58 "In addition to choices between federal courts and state courts, another consideration in the forum selection process is whether more than one state provides a potential forum. In some cases, a litigant may be able to satisfy subject matter jurisdiction, personal jurisdiction, and venue prerequisites in more than one state, thereby providing a choice between (or among) courts in different states. Subject to subject matter jurisdiction, personal jurisdiction, and venue limitations, the litigant may have choices between state courts in different states, between federal courts in different states, or between (or among) a patchwork of options involving both federal and state courts." (BASSETT, Debra Lyn, The forum game, cit., p. 337).

${ }^{59}$ Em igual sentido, Vera Maria Barrera Jatahy (Do conflito de jurisdições: a competência internacional da justiça brasileira, cit., p. 37), que é citada textualmente por Fredie Didier Junior, Paula Sarno Braga e Rafael Oliveira (Curso de direito processual civil: direito probatório, decisão judicial, cumprimento e liquidação da sentença e coisa julgada. 3. ed. rev., ampl. e atual. Salvador: JusPodivm, 2008. v. 2, p. 116), que parecem ter mudado de opinião posteriormente, ao estender o conceito a conflitos de competência no âmbito da jurisdição brasileira (vide nota seguinte).

${ }^{60}$ Fredie Didier Junior e Hermes Zaneti utilizam-se da conceituação dada por Vera Jatahy ao forum shopping e, a partir dali, intentam uma teoria voltada à fixação da competência para as ações coletivas, pela discrição jurisprudencial negativa, isto é, a partir da assimilação da doutrina do forum non conveniens pelo direito pátrio. Para isso, os autores intitulam como forum shopping qualquer escolha de foro por parte do demandante, inclusive envolvendo competências exclusivamente nacionais concorrentes, e afastando-se das origens do instituto no direito internacional privado (DIDIER JUNIOR, Fredie; ZANETI JÚNIOR, Hermes. Curso de direito processual civil: processo coletivo. 6. ed. rev., ampl. e atual. Salvador: JusPodivm, 2011. v. 4, p. 117). Esse uso equivocado da expressão forum shopping foi admitido por Pablo Slonimsqui (Forum shopping. Buenos Aires: Fabián J. di Plácido Editor, 2008), para tratar da manipulação de competências criminais na Argentina, para favorecimento de réus. Neste caso, o autor faz uma mea culpa pelo uso equivocado, com o declarado propósito de chamar a atenção para a denúncia de que trata sua obra. 


\subsection{A teoria do conflito de jurisdições}

Com bem explica Fragistas, não é importante saber se o litígio encontra-se na competência da categoria A ou da categoria B dos tribunais de um Estado, ou se deve ser julgado por este ou aquele juiz nacional. Trata-se de determinar se um litígio em concreto, resultante de uma relação internacional, deve ou pode ser examinado pela Justiça do Estado A ou B. ${ }^{61}$

Como já se afirmou, o estudo do conflito de jurisdições é matéria pertinente ao direito internacional privado ${ }^{62}$. Embora alguns entendam que o tema pode ser tratado no âmbito do direito internacional processual ${ }^{63}$, a peculiaridade do tema parece levar a um tratamento diferenciado.

Isso porque a estrutura das normas destinadas à solução do conflito de jurisdições encontradas na lei não é a mesma daquelas que se propõem a resolver o conflito de leis materiais. As primeiras são normas negativas, que afastam ou aprovam a jurisdição estrangeira, e não se prestam a impor a matéria a determinada jurisdição (e é dessa maneira que o forum non conveniens constitui uma instituição desconhecida ao direito brasileiro). Por outro lado, o conflito de leis materiais se dá a partir dos elementos de conexão, pela aplicação do método do direito internacional privado.

Conforme aponta Dolinger, embora haja várias concepções sobre os objetos do direito internacional privado, a corrente predominante distingue o conflito de jurisdições como uma delas, tratando de definir a a competência do Poder Judiciário na solução dos conflitos "que envolvem pessoas, coisas ou interesses que extravasam os limites de uma soberania". ${ }^{64}$

No caso específico do conflito de jurisdições, o demandante pode ter a prerrogativa de optar por uma ou outra jurisdição, ou ainda por ambas, como na hipótese do artigo 24 do NCPC, que afasta os efeitos da litispendência internacional. Nesse caso, o réu terá que se submeter a tais

61 FRAGISTAS, Charalambos N. La compétence internacionale en droit privé. Recueil des Cours de l'Académie de Droit International de La Haye, v. 104, n. 3, p. 167, 1961.

62 JATAHY, Vera Maria Barrera, Do conflito de jurisdições: a competência internacional da justiça brasileira, cit., p. 13.

${ }^{63}$ GOLDSCHMIDT, Werner, Sistema e filosofia del derecho internacional privado, cit., v. 3, p. 68.

${ }^{64}$ DOLINGER, Jacob. Direito internacional privado: parte geral. Rio de Janeiro: Freitas Bastos, 1986. p. 2. 
escolhas $^{65}$. Como bem aponta Barbosa Moreira, referindo-se a redação do artigo 90 do CPC de 1973, e que foi repetido no artigo 24 do NCPC, o legislador brasileiro não parece ter seguido uma redação perfeita, pois o sentido da norma é o de afastar os efeitos da litispendência internacional no Brasil, e não negar sua existência. ${ }^{66-67}$

Outro ponto que merece relevo é a multiplicação exponencial dos casos de direito internacional privado em questões processuais e cooperacionais, passando de um direito internacional privado acadêmico para um direito internacional privado real, nas palavras de Diego Arroyo. ${ }^{68}$

\subsection{Conflito de jurisdições e direito internacional privado}

Serpa Lopes aponta que o problema do conflito de jurisdições envolve três subespécies: a) a competência do órgão judicante de um determinado Estado em face de outros; b) a norma processual, como rito da ação; c) a eficácia da sentença estrangeira. ${ }^{69}$

Em 1947, Valladão preconizou a supressão desses problemas, afirmando que "o melhor caminho, tipicamente de Direito Internacional público, [será] uma convenção entre os vários Estados, estabelecendo lei uniforme sobre competência judiciária, levaria à supressão de tais conflitos, igualando as várias leis internas da matéria". ${ }^{70}$

${ }^{65}$ BASSO, Maristela; CARVALHO, Patrícia Luciane de (Orgs.). Lições de direito internacional: estudos e pareceres de Luiz Olavo Baptista. Curitiba: Juruá, 2008. p. 188.

${ }^{66}$ MOREIRA, José Carlos Barbosa, Problemas relativos a litígios internacionais, in Temas de direito processual: quinta série, cit., p. 144.

${ }^{67}$ Gustavo Monaco considera que o termo litispendência internacional pode levar a uma contradição em termos. Ao se considerar a jurisdição um atributo do Estado (pelo pressuposto weberiano da legitimidade), toda jurisdição exercida em qualquer esfera provém originariamente do próprio Estado. Logo, ao se tratar de processos movidos em diversos Estados, sejam eles coincidentes ou não, haveria uma contradição em se considerar a ocorrência de litispendência internacional, pelo fato de que cada Estado exercita sua própria jurisdição, não havendo como ocorrer "pendência de lides" em jurisdições estrangeiras autônomas (MONACO, Gustavo Ferraz de Campos. Le droit applicable par la Cour: une question de droit international public ou de droit international privé harmonisé? In: COLLOQUE: UNE COUR CONSTITUTIONNELLE INTERNATIONALE AU SERVICE DU DROIT DÉMOCRATIQUE ET DU DROIT CONSTITUTIONNEL, 16 e 17 de junho de 2015, Rabat, Marrocos. Inédito).

${ }^{68}$ FERNÁNDEZ ARROYO, Diego P. Aspectos esenciales de la competencia judicial internacional en vistas de su reglamentación interamericana. In: PICAND ALBÓNICO, Eduardo; LLANOS MANSILLA, Hugo (Coords.). Estudios de derecho internacional: libro homenaje al profesor Santiago Benadava. Santiago de Chile: Livrotecnia, 2008. v. 2, p. 294.

${ }^{69}$ LOPES, Miguel Maria Serpa. Comentários à Lei de Introdução ao Código Civil. 2. ed. rev. e aum. Rio de Janeiro: Freitas Bastos, 1959. v. 3, p. 75.

${ }^{70}$ VALLADÃO, Haroldo. Da competência judiciária no direito internacional privado. In: Estudos de direito internacional privado. Rio de Janeiro: J. Olympio, 1947. p. 7. 
A verdade é que passados mais de sessenta anos dessa afirmação, e tendo sido celebradas diversas convenções sobre tais matérias (como os Protocolos de Las Leñas, Ouro Preto e Buenos Aires, no Mercosul, e o Regime Bruxelas-Lugano, na União Europeia), o problema do conflito de jurisdições é hoje mais presente do que nunca.

Mesmo que as diferentes jurisdições tivessem entendimentos comuns sobre as normas de competência, ainda assim haveria possíveis discussões sobre os elementos de conexão aplicáveis a cada ordenamento; se no Brasil a capacidade da pessoa é regida pela lei do domicílio (art. $7^{\circ}$ da LINDB), na França a capacidade é regida pela lei da nacionalidade (“Article $3^{\circ}$. Les lois concernant l'état et la capacité des personnes régissent les Français, même résidant en pays étranger.").

E, mesmo que os elementos de conexão estejam em sintonia, ainda assim há possibilidade de controvérsia oriunda da qualificação do instituto jurídico sob exame. São clássicos os exemplos de Bartin sobre o Caso Bartholo, ou a sucessão do maltês; o testamento hológrafo do holandês; e o casamento do grego ortodoxo. ${ }^{71}$

Também existem questões relacionadas à recepção da norma jurídica como direito ou como fato $^{72}$, a aceitação ou não do reenvio a outra lei, determinada pela lex causae, e o respeito à ordem pública, nos termos do artigo 17 da LINDB. $^{73}$

Gustavo Monaco acrescenta o filtro de constitucionalidade da lei estrangeira, que deve ser realizado duplamente: tanto pelos modelos de controle vigentes no Estado do foro (lex fori) como pela análise do sistema jurídico do Estado cuja lei se vê aplicada por determinação das regras de conflito (lex cause). ${ }^{74}$

Ainda existe a problemática da autonomia da vontade, trazida por Dumoulin, com suas várias implicações. Segundo Strenger, os caminhos teóricos pelos quais transita o princípio da autonomia da vontade são tortuosos, cheios de altos e baixos, suscetíveis, com

\footnotetext{
${ }^{71}$ DOLINGER, Jacob, Direito internacional privado: parte geral, cit., p. 365.

${ }^{72}$ Vera Maria Barrera Jatahy afirma que os tribunais brasileiros já resolveram a questão desde o RE n. 93.131 (Do conflito de jurisdições: a competência internacional da justiça brasileira, cit., p. 14).

${ }^{73}$ RODAS, João Grandino. Direito internacional privado brasileiro. São Paulo: Revista dos Tribunais, 1993. p. 52.

${ }^{74}$ MONACO, Gustavo Ferraz de Campos. Controle de constitucionalidade da lei estrangeira. São Paulo: Quartier Latin, 2013. p. 139.
} 
maior ou menor intensidade, às fixações doutrinárias ligadas às vicissitudes do processo histórico, influenciando as legislações e a jurisprudência. ${ }^{75}$

Arremata Vera Jatahy, incluindo ainda o foro contratual, a cláusula de arbitragem, o forum shopping e o forum non conveniens como questões processuais intimamente ligadas à teoria do direito internacional privado, visto ser o direito tutelado, em última análise, o interesse individual nas relações internacionais. ${ }^{76}$

Por fim, devem-se segregar os conflitos positivos de jurisdição dos negativos. Há um conflito positivo de jurisdição na hipótese de que uma ação possa ser instaurada em diversas jurisdições ao mesmo tempo ${ }^{77}$. E há um conflito negativo de jurisdição quando todos os Estados envolvidos na relação jurídica material consideram-se incompetentes para conhecer do litígio, denegando-se justiça às partes litigantes. ${ }^{78}$

\subsection{Normas delimitadoras da jurisdição}

As normas delimitadoras de jurisdição, tanto de direito internacional propriamente dito - derivada de princípios, costumes ou de tratados -, como de direito interno, formuladas pelas normas locais, no dizer de Vera Jatahy, desempenham a mesma função, ou seja, marcam os limites do exercício do poder jurisdicional de um Estado, de modo a solucionar o conflito de jurisdições ${ }^{79}$. Em função desse controle, o exercício da autonomia da vontade fica condicionado à esfera de atuação que lhe é assegurada pelo próprio poder oriundo da regulação, quer seja o tratado, quer seja a norma interna do Estado.

As fontes delimitadoras da jurisdição do Estado são a fonte interna e a fonte externa, esta última derivada dos tratados. No primeiro caso, as normas processuais de

\footnotetext{
${ }^{75}$ STRENGER, Irineu. A autonomia da vontade como suporte do sistema civilista e direito internacional privado e direito interno. Boletim Científico da Escola do Ministério Público da União. Brasília, v. 3, n. 10, p. 70, jan./mar. 2004.

${ }^{76}$ JATAHY, Vera Maria Barrera, Do conflito de jurisdições: a competência internacional da justiça brasileira, cit., p. 15.

${ }^{77}$ No dizer de Antonio Boggiano, "síndrome da competência internacional múltipla" ou fenômeno "juridicamente multinacional" (BOGGIANO, Antonio. Curso de derecho internacional privado: derecho de las relaciones privadas internacionales. 3. ed. Buenos Aires: Abeledo-Perrot, 2001. p. 4).

78 Segundo Antonio Boggiano, "síndrome da falta de competência internacional" ou caso "apátrida multinacional" (BOGGIANO, Antonio, Curso de derecho internacional privado: derecho de las relaciones privadas internacionales, cit., p. 6).

${ }^{79}$ JATAHY, Vera Maria Barrera, op. cit., p. 18.
} 
cada sistema jurídico determinam as diretrizes, sejam elas implícitas, como no sistema do common law, sejam elas explícitas, como no caso do Brasil (arts. 21 a 25 do NCPC), quanto à atuação do Estado numa lide posta à exame. No segundo caso, firmados os acordos internacionais, que por sua vez podem ser bilaterais ou multilaterais, os Estados acordam em criar ou modificar o direito ao exercício da jurisdição, como é o caso do Regime de Bruxelas-Lugano, vigente na União Europeia.

Especificamente no caso do Brasil, existem hipóteses em que a Justiça brasileira se considera competente para julgar uma demanda, não excluindo a possibilidade de a causa ser julgada por outra jurisdição (estrangeira). São casos de jurisdição internacional concorrente, prevista nos artigos 21 e 22 do NCPC, ou de exercício potencialmente concomitante da jurisdição estatal. Em síntese, ocorrem tais hipóteses: a) se o réu tiver domicílio no Brasil (art. 21, I); b) se a obrigação tiver que ser cumprida no Brasil (art. 21, II); c) ou se a ação se originar de fato ocorrido ou ato praticado no Brasil (art. 21, III). Em todos os casos, pouco importa a nacionalidade dos litigantes. O NCPC ainda acrescentou novas possibilidades de competência concorrente da Justiça brasileira, que são: d) as ações de alimentos em que o credor é domiciliado no Brasil (art. 22, I); e) caso o devedor de alimentos mantenha vínculos no Brasil, tais como posse ou propriedade de bens, recebimento de renda ou obtenção de benefícios econômicos (art. 22, II); e, f) caso as partes, expressa ou tacitamente, tenham se submetido à jurisdição nacional (art. 22, III), sendo que, nesse último caso, trata-se de uma hipótese de jurisdição exclusiva, e não concorrente. $^{80}$

Cada Estado determina quais as competências deve ele exercitar, avocando-as pelo seu próprio ordenamento, ou mediante tratados internacionais.

O conflito de jurisdições pode se apresentar de maneira positiva, com vários Estados potencialmente competentes ${ }^{81}$ para apreciar as lides decorrentes de tal ou qual relação jurídica, ou negativa. Esse último caso ocorre na hipótese em que nenhum dos

${ }^{80}$ LUÍS, Daniel Tavela; COSTA, José Augusto Fontoura. A internacionalização pelo novo CPC. Valor Econômico, de 12 jun. 2015, p. E2.

${ }^{81}$ BOGGIANO, Antonio, Curso de derecho internacional privado: derecho de las relaciones privadas Internacionales, cit., p. 4. 
Estados potencialmente envolvidos na relação jurídica material declara deter jurisdição sobre a lide. ${ }^{82}$

\subsection{Princípios de jurisdição internacional}

A grande diversidade quanto aos modos e a forma de se exercer as diversas soberanias gera, como não poderia deixar de ser, uma grande diversidade de ordenamentos jurídicos nacionais, em sua grande maioria formalmente legítimos. E cada um desses ordenamentos contém normas que regulam sua respectiva extensão e alcance, cuja delimitação, no campo internacional, denomina-se jurisdição internacional. ${ }^{83}$

Da noção de se aplicar a lei estrangeira dita competente, segundo Augustinho Fernandes Dias da Silva, é que nasce a ideia de que também certos casos podem ou devem ser entregues às cortes estrangeiras (em outras palavras, reservados à jurisdição estrangeira). Ou ainda, do conflito de jurisdições nasceria o conflito de leis, o que justificaria, a partir da competência legislativa (isto é, da previsão normativa quanto à aplicação do ordenamento de um determinado Estado), a competência judiciária (do mesmo modo, a avocação da competência de um determinado tribunal sobre uma determinada lide). ${ }^{84}$

Vários são os critérios que determinam a autolimitação do Estado quanto a sua própria jurisdição. Segundo Fragistas, os critérios principais seriam: (a) a nacionalidade da partes; (b) o domicílio do réu; (c) foros especiais relativos ao objeto do litígio e sua vinculação com o território; (d) foros especiais fundados na conexão com outro litígio; (e) foro do lugar da situação dos bens do réu; (f) presença pessoal do devedor. ${ }^{85}$

Esses critérios não são unânimes, e muitas vezes se contrapõem, criando os conflitos de jurisdição, como já visto.

82 BOGGIANO, Antonio, Curso de derecho internacional privado: derecho de las relaciones privadas Internacionales, cit., p. 6.

${ }^{83}$ HUCK, Hermes Marcelo. Sentença estrangeira e lex mercatoria: horizontes e fronteiras do comércio internacional. São Paulo: Saraiva, 1994. p. 6. O autor faz referência ao termo "competência internacional", com base no revogado Código de Processo Civil de 1973.

84 SILVA, Agustinho Fernandes Dias da. Direito processual internacional: efeitos internacionais da jurisdição brasileira e reconhecimento de jurisdição estrangeira no Brasil. Rio de Janeiro: Villani Filhos, 1971. p. 18.

${ }^{85}$ FRAGISTAS, Charalambos N., La compétence internacionale en droit privé, cit., p. 163. 
O direito internacional privado hodiernamente tem como fim precípuo regular as relações internacionais entre indivíduos, inclusive sob a ótica da força expansiva dos direitos humanos, e isso faz com que a análise de seus pressupostos tenha clara ligação com seus princípios formadores. E isso é particularmente importante em se tratando dos temas afeitos aos conflitos de jurisdição. ${ }^{86}$

A proteção dos direitos advém de uma heroica história de conquistas e lutas, muito longe de se ver encerrada. A defesa desses direitos encontra-se em diferentes níveis de aceitação e respeitabilidade, num gradiente variado de existência, validade e eficácia. ${ }^{87}$

Foi no processo de transição de uma moralidade essencialmente coletivista da Idade Média, para uma moralidade individualista ${ }^{88}$ dos últimos séculos, que os direitos humanos alcançaram a merecida importância.

A proteção do ser humano diante do Estado, nos séculos XVII e XVIII, é apontada como a causa principal para o desenvolvimento dos direitos humanos de primeira geração. $^{89}$

Tornou-se necessária a criação de mecanismos jurídicos de proteção da esfera de autonomia dos indivíduos que possibilitassem o pleno desenvolvimento de seus direitos. Rogava-se por um Estado eficaz, com um mínimo de controle sobre as atividades humanas. $^{90}$

${ }^{86}$ JAYME, Erik. Identité culturelle et intégration: le droit international privé post moderne. Recueil des Cours de l'Académie de Droit International de La Haye, v. 251, p. 44, 1995.

${ }^{87}$ MONACO, Gustavo Ferraz de Campos. A proteção da criança no cenário internacional. Belo Horizonte: Del Rey, 2005. p. 15-86.

${ }^{88}$ BOBBIO, Norberto. A era dos direitos. Rio de Janeiro: Elsevier, 2004. p. 80.

${ }^{89}$ Paulo Bonavides usa a expressão "dimensão", ao invés de "geração" de direitos humanos. O autor lembra que a expressão "gerações de direitos fundamentais" foi primeiramente utilizada por Karel Vasak, na aula inaugural de 1979 dos cursos do Instituto Internacional dos Direitos do Homem, em Estrasburgo (BONAVIDES, Paulo. Curso de direito constitucional. 18. ed., atual. São Paulo: Malheiros, 2006. p. 563).

${ }^{90} \mathrm{Com}$ a Declaração dos Direitos do Homem e do Cidadão, de 26.08.1789, foi dado o primeiro passo rumo à internacionalização dos direitos humanos. A Declaração, de conteúdo marcadamente universalista originária de uma revolução burguesa - e com fortes amarras no pensamento liberal ocidental, inaugurou uma nova fase dos direitos humanos, ao fixar as diretrizes essenciais para a sua internacionalização. $\mathrm{O}$ processo de universalização e internacionalização dos direitos humanos ocorreu de forma paralela à evolução do Estado absolutista para o Estado de Direito, instituição por gênese comprometida com a proteção dos direitos insculpidos nas Cartas Políticas (CAGGIANO, Mônica Herman Salem. Os direitos fundamentais e sua universalização. Revista Brasileira de Direito Constitucional, n. 4, p. 760, jul./dez. 2004). 
O desenvolvimento tecnológico advindo da Revolução Industrial, a evolução das ciências em geral e as revoluções socialistas do século XIX desencadearam o surgimento dos direitos humanos de segunda geração, os chamados direitos sociais.

O Estado, portanto, ampliou sua esfera de atuação, assumindo deveres de promoção e concretização de vasta gama de direitos. ${ }^{91}$

Ao lado dos direitos humanos de primeira e segunda geração, há os direitos de caráter transindividual, isto é, aqueles que dizem respeito a uma coletividade de indivíduos. Essa terceira geração de direitos humanos busca tutelar direitos que muitas vezes se referem a um número indeterminado de pessoas, mas que são essenciais para a vida humana ${ }^{92}$, tais como os idosos, as crianças e os adolescentes, as minorias étnicas, os portadores de necessidades especiais etc.

Infelizmente, a prática mostrou que a defesa dos direitos humanos não se mostrou factível unicamente pelos Estados nacionais.

Muito ao contrário, os Estados se mostraram muitas vezes os maiores violadores dos direitos humanos, como foi o caso do regime nacional-socialista na Alemanha, do stalinismo soviético, da Revolução Cultural chinesa, ou mesmo dos regimes ditatoriais latino-americanos, africanos ou assemelhados. ${ }^{93}$

Por conta dessa realidade, surgiram órgãos de cooperação ou multiestatais de proteção dos direitos humanos no cenário pós-Segunda Guerra Mundial.

A internacionalização dos direitos humanos, reconhecida pela Carta da ONU, fez com que todos os Estados tivessem a obrigação (universal) de assegurar a proteção aos direitos humanos ao maior número de indivíduos; nesse cenário, as organizações internacionais surgiram com o propósito de promover tal objetivo. ${ }^{94}$

\footnotetext{
${ }^{91}$ CAGGIANO, Mônica Herman Salem, Os direitos fundamentais e sua universalização, cit., p. 763.

${ }^{92}$ BOBBIO, Norberto, A era dos direitos, cit., p. 85.

93 Ver, por todos: LAFER, Celso. A reconstrução dos direitos humanos: um diálogo com o pensamento de Hannah Arendt. São Paulo: Companhia das Letras, 1991.

${ }^{94}$ PIOVESAN, Flávia. Direitos humanos e o direito constitucional internacional. São Paulo: Saraiva, 2008. p. 157; e RAMOS, André de Carvalho. Direitos humanos em juízo. São Paulo: Max Limonad, 2001. p. 383.
} 
Sendo a jurisdição internacional uma das formas de se garantir o direito dos Estados, a ONU trouxe de volta o debate sobre a institucionalização de um tribunal internacional com competência para julgar os litígios entre os Estados. E, a partir de 1989, com o fim da Guerra Fria, foram criadas circunstâncias favoráveis ao surgimento de um novo desenho político para a comunidade, e iniciou-se um processo de jurisdicionalização do direito internacional, a partir da multiplicação de instâncias judiciais, o que permitiu à sociedade internacional contar com vários órgãos sistematizados, responsáveis por julgar litígios e colocar fim aos conflitos entre sujeitos de direito internacional ou fazer reconhecer, à luz do direito, um dispositivo normativo consagrado por tais sujeitos. ${ }^{95}$

A preocupação por parte do direito internacional moderno com os direitos humanos é verificada com a construção cada vez maior de convenções internacionais que reforçam a preocupação e promoção explícita dos direitos do homem ${ }^{96}$. Essa postura de preocupação com os direitos fundamentais também é observada em matéria de conflitos de jurisdição. Segundo Erik Jayme: "Nous retrouvons la même tendance en matiére de conflits de jurisdictions. Les critères permettant de déterminer la compétence des juridictions d'un État suivent l'idée que les droits de la défense font partie des droits de l'homme."97

Se cada Estado tem uma liberdade absoluta de exercer sua vontade na definição de seus critérios internos de fixação da competência internacional, parece também claro que os demais Estados teriam idêntica liberdade na fixação de critérios próprios para reconhecer a extensão da eficácia dos provimentos e sentenças que dali fossem originários. $^{98}$

Porém, os elementos oferecidos pela doutrina e pela manifestação positiva da vontade interestatal mostram que o direito internacional geral, a declaração real de normas

\footnotetext{
${ }^{95}$ MENEZES, Wagner. Tribunais internacionais: jurisdição e competência. São Paulo: Saraiva, 2013. p. 145.

${ }^{96}$ Exemplificando: Convenção da Haia de 1980 sobre o sequestro internacional de crianças (ratificada pelo Brasil em 1993); Convenção das Nações Unidas de 1989 para proteção dos direitos da criança (ratificada pelo Brasil em 1990). Ver, por todos: MONACO, Gustavo Ferraz de Campos, A proteção da criança no cenário internacional, cit., 2005.

97 JAYME, Erik, O direito internacional privado do novo milênio: a proteção da pessoa humana face à globalização, cit., p. 135.

98 Jellinek defendeu não haver uma ordem jurídica internacional, posto o Estado guardar sua liberdade de agir; mas essa dita ordem jurídica internacional passaria a existir a partir do momento em que o Estado aceitasse essas obrigações em um ato de autolimitação da própria soberania, em sua vontade metafísica (JELLINEK, Georg. Teoria general del Estado. Traducción y prólogo de la segunda edición alemana por Fernando de los Ríos Urruti. México: Fondo de Cultura Económica, 2000. p. 125).
} 
aplicáveis a todos os Estados, não seria a generalização puramente teórica dos princípios abstratos de conteúdo uniforme.

Da análise dos diversos ordenamentos internacionais que regulam as competências internas de sua respectiva jurisdição, parece clara a necessidade de se superar a distinção baseada exclusivamente em espécies normativas (quer baseada em nacionalidade, domicílio ou qualquer outra), em favor de uma distinção baseada no caráter pluridimensional dos enunciados.

As regras podem ser dissociadas dos princípios quanto ao modo como prescrevem o comportamento. Enquanto as regras são normas imediatamente descritivas, na medida que estabelecem obrigações, permissões e proibições mediante a descrição da conduta a ser adotada, os princípios são normas imediatamente finalísticas, já que estabelecem um estado de coisas para cuja realização é necessária a adoção de determinados comportamentos. ${ }^{99}$

Os princípios estabelecem um estado ideal de patamares a serem atingidos, pelo qual o intérprete irá verificar a adequação do comportamento, visando a resguardar tais patamares.

As regras podem ser dissociadas dos princípios quanto à justificação que exigem. A interpretação e a aplicação das regras exigem uma avaliação da correspondência entre a construção conceitual dos fatos e a construção conceitual da norma e da finalidade que lhe dá suporte. ${ }^{100}$

Se a regra de jurisdição internacional francesa pressupõe a nacionalidade de seus súditos como critério exclusivo de sua própria jurisdição, independentemente da sede da relação jurídica controvertida - no dizer de Savigny -, isso é uma regra e, como tal, instituidora de uma obrigação absoluta não contestável por nenhum outro ordenamento. Por outro lado, situações da vida podem fazer com que essa regra possa parecer injusta, por exemplo, nas hipóteses em que o nacional francês foi o responsável por um acidente de

\footnotetext{
99 ÁVILA, Humberto Bergmann. Teoria dos princípios: da definição à aplicação dos princípios jurídicos. 3. ed. aum. São Paulo: Malheiros, 2004. p. 63.

100 ÁVILA, Humberto Bergmann. A distinção entre princípios e regras e a redefinição do dever de proporcionalidade. Revista de Direito Administrativo, Rio de Janeiro, n. 215, p. 152, jan./mar. 1999.
} 
trânsito na África do Sul, contra africanos, durante suas férias. Nessa hipótese, a investigação da finalidade da própria norma permitiria afastar - dentro da própria corte francesa, em tese - o conteúdo dessa mesma norma. Porém, para isso, é preciso fundamentação que supere a incidência da regra. ${ }^{101}$

No caso dos princípios, o elemento descritivo cede lugar ao elemento finalístico, havendo necessidade de uma avaliação de correlação entre os efeitos da regra e o caso concreto. $^{102}$

Muito embora não seja objeto deste trabalho o aprofundamento teórico sobre postulados, princípios e regras, parte-se do pressuposto de que, se o direito internacional pós-moderno, com todos os trancos e solavancos, busca evoluir para a regulação justa das relações transnacionais entre estrangeiros, deve haver postulados universais que possam estruturar a aplicação dos princípios que regem a jurisdição internacional de cada Estado.

Um postulado básico é o da razoabilidade. Estados que tenham liberdade absoluta para legislar sobre sua própria competência internacional, no conceito de autolimitação de Jellinek, podem deixar de ser razoáveis pelas mais diversas razões, sejam elas nobres ou não. Porém, é claro que tais razões (e seu valor) não parecem suficientes a justificar eventuais excessos ${ }^{103}$. Fala-se de razoabilidade nas mais diversas acepções, sendo que, para os efeitos deste trabalho, leva-se em conta uma diretriz que exige a relação das normas gerais com as individualidades do caso concreto, mostrando sob qual perspectiva a norma deve ser aplicada, quer indicando em quais hipóteses o caso individual, em virtude de suas especificidades, deixa de se enquadrar na norma geral. A razoabilidade também é empregada como diretriz que demanda uma vinculação das normas jurídicas com o mundo ao qual elas fazem referência, perseguindo uma relação que faça sentido entre a medida

\footnotetext{
101 SAVIGNY, Friedrich Carl von, Sistema do direito romano atual, cit., p. 56.

${ }^{102}$ As normas atuam sobre as outras normas do mesmo sistema jurídico, especialmente definindo-lhes o seu sentido e o seu valor. Os princípios, por serem normas imediatamente finalísticas, estabelecem um estado ideal a ser buscado, que diz respeito a outras normas do mesmo sistema de regras. Logo, os princípios são normas que permitem a compreensão do espírito das regras. Essa aptidão para produzir efeitos em diferentes níveis e funções é qualificada como função eficacial (FERRAZ JÚNIOR, Tércio Sampaio. Introdução ao estudo do direito: técnica, decisão, dominação. 3. ed. São Paulo: Atlas, 2001. p. 196).

103 STEINMETZ, Wilson Antônio. Colisão de direitos fundamentais e o princípio da proporcionalidade. Porto Alegre: Livraria do Advogado, 2001. p. 143.
} 
adotada e o fim que ela pretende atingir. Por fim, pode-se utilizar a razoabilidade como uma linha mestra que determina a relação de equivalência entre duas grandezas. ${ }^{104}$

Outro postulado é o da igualdade, regra consagrada em direito internacional desde os primeiros escritos de Vitoria e Suarez. Evidentemente, a concretização da igualdade no direito internacional privado - assim como em outros ramos - depende do critério de diferenciação, na medida que a questão meramente geográfica ou econômica não é passível de uma compreensão universal; sujeitos devem ser considerados iguais em liberdade, propriedade e dignidade. ${ }^{105}$

Ao lado dos demais, há que se considerar o postulado da proporcionalidade, oriundo do brocardo romano dar a cada um o que é seu (suum cuique tribuere). Ele se aplica a situações em que uma relação de causalidade entre dois elementos discerníveis, um meio e um fim, tenham uma relação positiva, de tal sorte que se possa analisar empiricamente se a solução é adequada (se o meio promove o fim), se é necessária (se não há outros meios disponíveis e adequados para promover o fim) e se é proporcional em sentido estrito (isto é, se as vantagens trazidas pela promoção do fim correspondem às desvantagens provocadas pela adoção do meio) ${ }^{106}$. Em síntese, a proporcionalidade como postulado que estrutura a aplicação dos princípios depende de elementos, tais como o meio (no caso, os critérios definidores da jurisdição internacional em determinado Estado), o fim concreto (a competência ou a incompetência dos tribunais nacionais) e uma relação de causalidade.

Os princípios que regem a competência internacional podem ser divididos em dois grupos: aqueles que admitem o uso da jurisdição de um determinado Estado, e aqueles que o vedam.

Essa divisão, proposta neste trabalho, é experimental e servirá posteriormente como baliza de diferenciação do forum shopping, entre uma opção lícita e uma ilícita.

\footnotetext{
${ }^{104}$ SILVA, Luis Virgílio Afonso da. O proporcional e o razoável. Revista dos Tribunais, São Paulo, v. 91, n. 798, p. 34, abr. 2002.

${ }^{105}$ MELLO, Celso Antônio Bandeira de. O conteúdo jurídico do princípio da igualdade. São Paulo: Malheiros, 2003. p. 53; e ÁVILA, Humberto Bergmann, Teoria dos princípios: da definição à aplicação dos princípios jurídicos, cit., p. 103.

${ }^{106}$ ÁVILA, Humberto Bergmann, Teoria dos princípios: da definição à aplicação dos princípios jurídicos, cit., p. 113.
} 
No primeiro grupo estão os princípios do acesso à Justiça, do forum necessitatis, da plenitudo jurisdictionis e da commitas gentium.

No segundo grupo estão os princípios da imunidade de jurisdição, da efetividade, e da jurisdição exorbitante.

\subsubsection{Princípio positivos de incidência e reconhecimento da jurisdição internacional}

\subsubsection{Princípio do acesso à Justiça}

No Brasil, este princípio é um direito fundamental presente na Constituição Federal (art. $5^{\circ}, \mathrm{XXXV}$ ), com conteúdo amplo e profundo, sendo chamado pelos processualistas de princípio da inafastabilidade do controle jurisdicional. Ele assegura que todos - nacionais ou estrangeiros - tenham acesso ao Poder Judiciário brasileiro, dentro das regras processuais e materiais aplicáveis. ${ }^{107}$

No âmbito internacional, a consagração deste princípio nos Estados de tradição romano-germânica choca-se com o forum non conveniens do common law, como será tratado com mais vagar nos próximos tópicos.

A Corte Europeia de Direitos Humanos considerou o direito de acesso às cortes nacionais um dos mais importantes princípios da Convenção Europeia de Direitos Humanos, não podendo haver limitações $\left(\text { art. } 6^{\circ}\right)^{108}$. Dentro deste princípio, pode-se incluir ainda o princípio da igualdade de tratamento processual, que impede qualquer tipo de discriminação, seja com base na nacionalidade, sexo, raça, cor, religião, opinião política, lugar de residência ou domicílio, idioma, origem social, orientação sexual etc.

107 CINTRA, Antônio Carlos de Araújo; GRINOVER, Ada Pellegrini; DINAMARCO, Candido Rangel, Teoria geral do processo, cit., p. 199; CANOTILHO, José Joaquim Gomes. Direito constitucional e teoria da constituição. Coimbra: Almedina, 2003. p. 483; CAPPELLETTI, Mauro; GARTH, Bryant. Acesso à justiça. Porto Alegre: Sergio Antonio Fabris, 1988. p. 15.

${ }^{108}$ Emblemáticos são os casos: (a) Golder v. Reino Unido (caso 4451/70, j. 21.02.1975), que permitiu a um prisioneiro propor uma ação de indenização contra o carcereiro, por calúnia; (b) Campbell e Fell v. Reino Unido (caso 8342/95, j. 28.06.1984), que permitiu que os prisioneiros acusados de liderarem um motim no presídio tivessem acesso aos seus advogados; (c) Airey $v$. Irlanda (caso 6289/73, j. 09.10.1979), que garantiu o direito de uma indigente ter acesso à justiça gratuita para se divorciar de seu marido. 
Dentro dessa premissa, Ada Pellegrini Grinover considera ser inconstitucional o artigo 835 do CPC em vias de ser revogado (cuja essência se mantém no art. 83 do NCPC), que obriga a parte autora estrangeira a prestar caução em processo, cuja natureza seria a de garantir o pagamento das custas e despesas oriundas de uma hipotética sucumbência ${ }^{109}$. O Protocolo de Las Leñas dispensa a prestação de caução entre litigantes do Mercosul, no mesmo sentido que os trabalhos da ALI e UNIDROIT, liderados por Geoffrey C. Hazzard Jr. e Michele Taruffo, consideram tal exigência contrária aos princípios modernos do processo civil internacional. ${ }^{110}$

De mais a mais, corolário das ordens jurídicas estatais e da consequente relatividade dos valores jurídicos é que a decisão judicial tem eficácia limitada à jurisdição onde foi proferida. Para o foro, no dizer de Amilcar de Castro, as sentenças estrangeiras não passam de fatos relevantes, mas destituídos de obrigatoriedade ${ }^{111}$. Nenhum Estado pode pretender que as suas sentenças judiciais tenham eficácia executiva de per se, em outras jurisdições. Porém, mediante procedimentos próprios (na maioria dos casos pelo exequatur ou pelo procedimento de homologação), se reconhecem as sentenças estrangeiras.

Segundo Wolff, se todas as sentenças pudessem ser admitidas em toda parte, haveria estabilidade das relações individuais no mundo inteiro e novas ações em outros Estados seriam supérfluas. ${ }^{112}$

O desenvolvimento das relações internacionais, assim como exige a limitação de direito estranho, também impõe, como conveniente, a revalidação ${ }^{113}$ das sentenças de tribunais estrangeiros. ${ }^{114}$

${ }^{109}$ GRINOVER, Ada Pellegrini. Os princípios constitucionais e o Código de Processo Civil. São Paulo: Bushatsky, 1975. p. 63.

${ }^{110}$ GLENN, H. Patrick. The ALI/UNIDROIT principles of transnational civil procedure as global standards for adjudication? Uniform Law Review = Revue de Droit Uniforme, Rome, v. 9, n. 4, p. 829-845, 2004.

${ }^{111}$ CASTRO, Amilcar de. Direito internacional privado. Rio de Janeiro: Forense, 1987. v. 1, p. 510.

${ }_{112}$ WOLFF, Martin. Private international law. 2nd. ed. Oxford: Clarendon Press, 1950. p. 250.

${ }_{113}$ CASTRO, Amilcar de, Direito internacional privado, cit., v. 1, p. 387.

${ }^{114}$ Pimenta Bueno registra que o Brasil reconhece tais princípios desde o Império: “A pedido da legação francesa de 14 de abril de 1845 e 18 de junho de 1946, respondidas pelo ministério dos negócios estrangeiros de 12 e 23 de junho de 1846, deu-se o exequatur a uma sentença arbitral da França para que tivesse seu cumprimento na província da Bahia. Relatório de 1847. Então não se fez distinção alguma entre as sentenças de árbitros voluntários ou forçados, nem de autoridades judiciárias. Nem tratou-se da revisão ou não quanto ao merecimento do julgado" (SÃO VICENTE, José Antonio Pimenta Bueno, Marquês de. Direito internacional privado e aplicação de seus princípios com referência às leis particulares do Brasil. Rio de Janeiro: Typographia Imp. e Const. de J. Villeneuve E.C., 1863. p. 143). 
Dois são os sistemas de atribuir eficácia e dar execução às sentenças estrangeiras ${ }^{115}$ : a actio judicati e o exequatur ${ }^{116}$. O primeiro é utilizado no common law, onde a sentença opera novação, ou seja, substitui a sentença estrangeira primitiva por um direito à condenação, não havendo processo de exequatur, e sim actio iudicati: para a obtenção do título executivo, a parte interessada deve propor uma nova ação, fundada em seu direito à condenação; em algumas jurisdições, a sentença estrangeira seria um meio de prova, havendo necessidade de uma nova sentença de mérito. ${ }^{117}$

Alguns ordenamentos incluem ainda, como critério de recepção da sentença estrangeira, a reciprocidade (como, por exemplo, o Código Processual Civil boliviano ${ }^{118}$ ou o Código Federal de Procedimentos Civis do México ${ }^{119}$ ). Portugal, na reforma Código de Processo Civil de 1995 e 1996, abandonou o princípio da reciprocidade, cuja condenação era praticamente unânime em sua doutrina ${ }^{120}$. O Brasil expressamente afastou esse requisito, conforme o artigo 26 , parágrafo $2^{\circ}$, do NCPC.

No que diz respeito à escolha da jurisdição mais favorável como exercício do princípio do acesso à Justiça, a atividade da parte se dá devido ao seu interesse no resultado da demanda pois, segundo Liebman, as partes são os sujeitos do contraditório instituído perante o juiz (são sujeitos do processo diversos do magistrado, para os quais

\footnotetext{
115 BATTIFOL, Henri. Traité élémentaire de droit international privé. 3e. éd. Paris: Librairie Générale de Droit et de Jurisprudence, 1959. p. 758.

${ }^{116}$ A palavra exequatur é utilizada para denominar a autorização necessária à execução; terceira pessoa do singular do verbo latino exsegui, executar, cumprir, significando que algo seja executado, ou "execute-se", "cumpra-se". No direito das gentes, significa "o ato pelo qual o governo estrangeiro aceita a pessoa do cônsul, reconhece seus poderes e prescreve às autoridades locais que o tratem como tal e o atendam em tudo que for de direito e de seu oficio" (PEREIRA, Lafayette Rodrigues. Princípios de direito internacional. Rio de Janeiro: Jacintho Ribeiro dos Santos, 1902. v. 1, p. 444). A Constituição Federal de 1988 emprega a palavra exequatur como sinônimo de "cumpra-se" em carta rogatória.

${ }^{117}$ CASTRO, Amilcar de, Direito internacional privado, cit., v. 1, p. 523.

118 “Art. 504. (Principio de Reciprocidad). I. Si no existiere tratado o convenio internacional suscrito con el país donde se dictó la sentencia cuya ejecución y cumplimiento se pretende, en vía de reciprocidad, se dará a ella la misma fuerza que se reconoce a las sentencias pronunciadas en el Estado Plurinacional de Bolivia."

119 “Artículo 564. Será reconocida en México la competencia asumida por un tribunal extranjero para los efectos de la ejecución de sentencias, cuando dicha competencia haya sido asumida por razones que resulten compatibles o análogas con el derecho nacional, salvo que se trate de asuntos de la competencia exclusiva de los tribunales mexicanos."

${ }^{120}$ Ver, por todos: RAMOS, Rui Manuel Gens de Moura. A reforma do direito processual civil internacional. Coimbra: Coimbra Editora, 1998. p. 22, citando a posição de Machado Villela e Ferrer Correia e, em sentido contrário, Alberto dos Reis.
} 
este deve proferir o seu provimento $)^{121}$. O juiz, por ser estranho ao conflito, é sujeito desinteressado e, portanto, imparcial.

O acesso à Justiça, como atividade principiológica das partes, é um árduo duelo, na imagem de Calamandrei. Ao invés de espadas sanguinárias, tem-se a força dos argumentos jurídicos; ao invés de uma batalha ferrenha que não é feita somente de boas razões, é necessária principalmente habilidade técnica para fazer os argumentos jurídicos ganharem relevância. $^{122}$

Barbosa Moreira também compara diversos modelos processuais com duelos cerrados, advertindo que não pode ser favorecido aquele que luta "com maior vigor ou maior habilidade - para não dizer com menores escrúpulos", em detrimento de quem possa ter razão nos planos material e processual. ${ }^{123}$

De qualquer forma, o princípio do acesso à Justiça parece ser o maior corolário dos princípios positivos que regem a jurisdição internacional.

\subsubsection{Princípio do forum necessitatis ${ }^{124}$}

Este princípio é originário do direito europeu e tem como propósito indicar um critério positivo de fixação de competência internacional (rectius: jurisdição) em caráter excepcional, levando em conta duas hipóteses principais: um conflito negativo de jurisdições e situações de fato, como uma guerra civil, calamidade pública ou desordem de grandes dimensões, que impeçam o autor de demandar no foro estrangeiro tido como competente.

${ }^{121}$ LIEBMAN, Enrico Tullio, Manual de direito processual civil, cit., v. 1, p. 89.

${ }^{122}$ ABDO, Helena Najjar. Abuso do processo. São Paulo: Revista dos Tribunais, 2007. p. 51; e CALAMANDREI, Piero, Il processo come giuoco, cit., p. 26.

${ }^{123}$ MOREIRA, José Carlos Barbosa, Duelo e processo, cit., p. 178.

124 Esse tema foi melhor desenvolvido num artigo autônomo, inclusive no qual se sugeriu que a Justiça brasileira poderia aplicar o princípio do forum necessitatis, mesmo sem previsão expressa nas leis processuais (CAMARGO, Solano de. Forum necessitatis: uma proposta de flexibilização dos critérios de competência internacional da justiça brasileira. In: MENEZES, Wagner et al. (Orgs.). Direito internacional em expansão. Belo Horizonte: Arraes, 2014. v. 4, p. 478). 
A invocação a esse princípio origina-se nas regras do artigo 6(1) da Convenção Europeia de Direitos Humanos ${ }^{125}$, que por sua vez prevê o direito a um julgamento justo a todos aqueles que estejam em solo europeu. Na França, faz-se referência ao princípio do forum necessitatis para se impedir a denegação de justiça. ${ }^{126}$

Para se evitar as consequências da falta de prestação jurisdicional, ocorrência combatida inclusive na Declaração dos Direitos do Homem, algumas legislações europeias previram expressamente que no conflito negativo de competências, ou na ocorrência de fato extraordinário impeditivo de se demandar no estrangeiro, possam as cortes nacionais, em caráter subsidiário e excepcional, apreciar as demandas ali propostas.

A Lei Federal de Direito Internacional Privado da Suíça, de 1987, previu que suas cortes poderiam conhecer de tais litígios, nas hipóteses em que a jurisdição estrangeira originariamente competente "não fosse possível" ou não pudesse ser "razoavelmente exigida". 127

No mesmo sentido, o Código de Direito Internacional belga de 2004 previu a competência "extraordinária" das cortes belgas ${ }^{128}$, sempre que a demanda tivesse "laços estreitos" com a Bélgica e a propositura da demanda no estrangeiro fosse "impossível” ou “não razoável”. Antes, a Lei de Direito Internacional Privado romena, de 1992, já havia previsto igual possibilidade, assim como os Códigos de Processo Civil holandês, austríaco $^{129}$ e português ${ }^{130}$, este último a partir de uma reforma de 1997.

125 ROSSOLILLO, Giulia. Forum necessitatis e flessibilità dei criteri di giurisdizione nel diritto internazionale privato nazionale e dell'Unione Europea. Cuadernos de Derecho Transnacional, Madrid, v. 2, n. 1, p. 403, mar. 2010.

${ }^{126}$ DE VISSCHER, Charles. Le déni de justice en droit international. Recueil des Cours de l'Académie de Droit International de La Haye, v. 52, p. 365, 1935.

127 "II. Foro di necessita. Se la presente legge non prevede alcun foro in Svizzera e un procedimento all'estero non è possibile o non può essere ragionevolmente preteso, sono competenti $i$ tribunali o le autorità svizzeri del luogo con cui la fattispecie denota sufficiente connessione."

128 "Art. 11. Nonobstant les autres dispositions de la présente loi, les juridictions belges sont exceptionnellement compétentes lorsque la cause présente des liens étroits avec la Belgique et qu'une procédure à l'étranger se révèle impossible ou qu'on ne peut raisonnablement exiger que la demande soit formée à l'étranger."

${ }^{129}$ ROSSOLILLO, Giulia, op. cit., p. 405.

${ }^{130}$ RAMOS, Rui Manuel Gens de Moura. A recente reforma do direito processual civil internacional em Portugal. In: BAPTISTA, Luiz Olavo; FONSECA, José Roberto Franco da (Coords.). $O$ direito internacional no terceiro milênio: estudos em homenagem ao professor Vicente Marotta Rangel. São Paulo: LTR, 1998. p. 802. 
No âmbito comunitário europeu, o Regulamento (CE) 4/2009 do Conselho, relativo à competência, à lei aplicável, ao reconhecimento e à execução das decisões e à cooperação em matéria de obrigações alimentares previu, em seu artigo $7^{\circ}$, que havendo conflito negativo de jurisdições, ou se "se revelar impossível conduzir um processo num Estado terceiro com o qual o litígio esteja estreitamente relacionado", pode o alimentado propor sua ação em qualquer Estado membro da Comunidade, desde que o litígio apresente "uma conexão suficiente com o Estado membro do tribunal demandado". ${ }^{131}$

Fora da Europa, há menção ao forum necessitatis no Código Civil do Quebec ${ }^{132} \mathrm{e}$ no Código Federal de Procedimentos Civis do México. ${ }^{133}$

A $3^{\text {a }}$ Conferência Interamericana de Direito Internacional Privado (CIDIP III), realizada em La Paz em 1984, aprovou a "Convenção Interamericana sobre Competência na Esfera Internacional para Eficácia Extraterritorial das Sentenças Estrangeiras”, cujo artigo $2^{\circ}$ prevê que os Estados signatários adotariam o princípio do forum necessitatis, visando a evitar a denegação de justiça em seu território ${ }^{134}$. Embora o Brasil tenha assinado a convenção em 24.05.1984, até o momento não houve a sua ratificação.

Este princípio está cada vez mais presente nos ordenamentos de tradição romanogermânicos, sempre em caráter extraordinário e subsidiário, havendo pouca margem para discricionariedade do julgador. ${ }^{135}$

131 “Art. 7. Forum necessitatis. Quando nenhum tribunal de um Estado-Membro for competente por força dos artigos $3^{\circ}, 4^{\circ}, 5^{\circ}$ e $6^{\circ}$, os tribunais de um Estado-Membro podem, em casos excepcionais, conhecer do litígio se não puder ser razoavelmente instaurado ou conduzido, ou se revelar impossível conduzir um processo num Estado terceiro com o qual o litígio esteja estreitamente relacionado. O litígio deve apresentar uma conexão suficiente com o Estado--Membro do tribunal demandado."

132 “Art. 3136. Bien qu'une autorité québécoise ne soit pas compétente pour connaître d'un litige, elle peut, néanmoins, si une action à l'étranger se révèle impossible ou si on ne peut exiger qu'elle y soit introduite, entendre le litige si celui-ci présente un lien suffisant avec le Québec."

133 "Artículo 565. No obstante lo previsto en el artículo anterior, el tribunal nacional reconocerá la competencia asumida por el extranjero si a su juicio éste hubiera asumido dicha competencia para evitar una denegación de justicia, por no existir órgano jurisdiccional competente. El tribunal mexicano podrá asumir competencia en casos análogos."

134 “Artículo 2: Se considerará también satisfecho el requisito de la competencia en la esfera internacional si, a criterio del órgano jurisdiccional del Estado Parte donde deba surtir efectos, el órgano jurisdiccional que pronunció la sentencia asumió competencia para evitar denegación de justicia por no existir órgano jurisdiccional competente."

${ }^{135}$ Inclusive, sobre o tema denegação da justiça, o Tratado Bilateral - Acordo de Garantia de Investimentos entre Brasil e EUA, promulgado pelo Brasil por meio do Decreto Legislativo n. 69, de 1965, prevê em seu artigo $2^{\circ}$ o conceito de denegação de justiça: "2. Ressalva-se que por denegação de justiça, nos têrmos do art. VI, $\S 3^{\circ}$, se entende: a inexistência de tribunais regulares, ou de vias normais de acesso à justiça; a recusa de julgar, de parte da autoridade competente, o retardamento injustificável da decisão judicial, com violação da lei processual interna." 
Porém, como será visto com mais vagar oportunamente, nos Estados de tradição do common law, os julgadores possuem larga margem de discricionariedade quanto ao exercício de sua própria competência internacional, de maneira que o princípio do forum necessitatis se dá posteriormente à aplicação do princípio do forum non conveniens $^{136}$, ou seja, após a confirmação do conflito negativo de jurisdições.

Por outro lado, existem situações em que as regras de competência internacional de um Estado são tão amplas, bastando que o réu tenha alguma propriedade (inclusive de coisa móvel) no foro para que surja a jurisdição desse Estado. Esse fenômeno foi metaforicamente chamado na doutrina europeia de "guarda-chuva sueco"137, pois bastaria a uma parte estrangeira esquecer um guarda-chuva na Suécia para que a Justiça local se considerasse competente para julgar uma ação de cobrança movida contra ele ${ }^{138}$, mesmo que a dívida tivesse sido contraída no exterior e envolvesse um credor também estrangeiro $^{139}$. Tal hipótese pode ser considerada um "foro exorbitante" e se afasta da ideia de acesso à Justiça presente no princípio do forum necessitatis.

\subsubsection{Princípio da plenitudo jurisdictionis}

Este princípio é particularmente importante, pois define que o Estado é soberano ao definir sua própria jurisdição sobre determinada lide, seja pelo fundamento de suas regras internas ou a partir dos tratados que tenha firmado. Dessa forma, tendo o Estado fixado jurisdição sobre a matéria, aplica-se o princípio da plenitudo jurisdictionis, fazendo com que os aspectos processuais e procedimentais sejam regidos exclusivamente pela lex fori.

As normas de processo civil, mesmo que relacionadas a elementos estrangeiros, são normas imperativas nacionais, não sendo possível que Estados terceiros interfiram e

\footnotetext{
${ }^{136}$ CHALAS, Christelle. L'exercice discrétionnaire de la compétence juridictionnelle en droit international privé. Aix-en-Provence: Presses Universitaire d'Aix-Marseille, Faculté de Droit et de Science Politique, 2000. v. 1, p. 129.

${ }^{137}$ SMIT, Hans, The terms jurisdiction and competence in comparative law, cit., p. 166.

${ }^{138}$ Swedish Code of Judicial Procedure, Chapter 10, Section 3: "In disputes concerning debt obligations, a person with no known residence in the Realm may be sued where property he owns is located. In disputes involving movable property, he may be sued where the property is located."

${ }^{139}$ GINSBURG, Ruth Bader; BRUZELIUS, Anders. Civil procedure in Sweden. Haia: Martinus Nijhoff, 1965. p. 160. Os autores são claros: "Because of the extensive reach of the rule, Swedish jurists sometimes refer to it as the 'umbrella rule' - the theory being that a non-resident debtor can subject himself to suit in Sweden if he injudiciously leaves an umbrella behind when he departs from Sweden."
} 
imponham regras de processo civil a outros Estados, a não ser nos casos previstos em tratados internacionais. ${ }^{140}$

No século XIII, Balduinus lançou a regra de que o processo devia ser regido pelo ius fori, não importando a nacionalidade dos litigantes, enquanto as questões de fundo poderiam ser regidas por regras de outro direito. ${ }^{141}$

Pimenta Bueno, em 1863, lembrava que as formalidades da Justiça, as competências, os termos do procedimento, enfim, todas as determinações ordinatoriae litis são regidas pela lei do Estado em que a demanda ou processo seja formado. ${ }^{142}$

Eduardo Espínola e Eduardo Espínola Filho afirmam "que sempre se entendeu que a cada Estado cabe organizar a sua Justiça, definir a atribuição de seus tribunais, regular a forma e os termos do processo, a execução das respectivas sentenças e os recursos contra as mesmas" ${ }^{\prime 14}$. Esses autores lembram que o Instituto de Direito Internacional, na sessão de Zurique de 1877, por proposta do jurista holandês Tobias Michael Carel Asser, aprovou o artigo $2^{\circ}$ das regras internacionais para prevenir os conflitos de leis quanto às formas processuais, determinando que as formas ordinatórias da instrução e do processo, desde a citação até a extinção da instância, deviam submeter-se à lei do lugar em que corre o litígio.

No Código Bustamante, o princípio foi consagrado em termos explícitos: “Art. 314. A lei de cada Estado contratante determina a competência dos tribunais, assim como sua organização, as formas do processo e de execução das sentenças, e os recursos contra as suas decisões". O artigo 315 exclui a organização ou o funcionamento de tribunais especiais, no território de um Estado, para os estrangeiros, membros de outros Estados contratantes. E para assegurar a situação igual de nacionais e estrangeiros pertencentes aos

140 DÁVALOS FERNÁNDEZ, Rodolfo. El conflicto de jurisdicciones o de competencia judicial internacional. Revista Cubana de Derecho, Havana, Unión Nacional de Juristas de Cuba, v. 30, n. 0, p. 6287, dic. 2007.

${ }^{141}$ CASTRO, Amilcar de, Direito internacional privado, cit., v. 1, p. 508. O autor lembra ainda que o artigo 10 das disposições preliminares do Código Civil italiano de 1865 determinava que a "competência e as formas processuais são reguladas pela lei do lugar onde sobrevém a sentença", servindo de inspiração para o artigo 15 da Lei de Introdução de 1916.

${ }^{142}$ SÃO VICENTE, José Antonio Pimenta Bueno, Marquês de, Direito internacional privado e aplicação de seus princípios com referência às leis particulares do Brasil, cit., p. 128.

${ }^{143}$ ESPÍNOLA, Eduardo; ESPÍNOLA FILHO, Eduardo. Do direito internacional privado brasileiro. In:

Tratado de direito civil brasileiro. Rio de Janeiro: Freitas Bastos, 1942. v. 8, t. 1, p. 101. 
outros Estados contratantes, o artigo 317 determinou que a competência ratione materiae e ratione personae não devem basear-se, para os Estados contratantes, na condição de nacionais ou estrangeiros, em prejuízo destes.

Irineu Strenger dividiu as formas de procedimento em formas ordinatórias e decisórias. As ordinatórias são as formas relativas à marcha do processo, sem que tenham a ver com o fundo do problema (rectius: mérito da causa), tais quais os atos processuais e o procedimento. Já as formas decisórias, que se relacionam com a resolução dos pontos controvertidos da demanda, devem aplicar a lei que rege o direito controvertido, sendo necessária a aplicação do método de direito internacional privado. Portanto, as formas ordinatórias sujeitam-se sempre à lex fori. ${ }^{144}$

O princípio da plenitudo jurisdictionis, enquanto ligado à soberania do Estado, está restrito aos seus limites territoriais, razão pela qual Cintra, Grinover e Dinamarco denominam tal fenômeno como o princípio da aderência ao território. ${ }^{145}$

Arruda Alvim considera ser "rigorosamente inócuo" ao Estado nacional pretender disciplinar os problemas atinentes à jurisdição ou competência de outros Estados, posto que essa disciplina e sua efetividade decorrem do pressuposto da soberania. ${ }^{146}$

Exemplificativamente, quando do não enquadramento de uma lide nas hipóteses previstas de competência internacional de um determinado Estado, este não poderia promover a remessa do caso para julgamento por outro Estado, justamente pela afronta que isso significaria à soberania desse outro Estado ${ }^{147}$. A ação, nessa hipótese, deveria ser julgada extinta.

\footnotetext{
${ }^{144}$ STRENGER, Irineu. Direito processual internacional. São Paulo: LTR, 2003. p. 29.

145 CINTRA, Antônio Carlos de Araújo; GRINOVER, Ada Pellegrini; DINAMARCO, Candido Rangel, Teoria geral do processo, cit., p. 131.

146 ARRUDA ALVIM, José Manual de, Competência internacional, cit., p. 15.

${ }^{147}$ De fato, de acordo com o direito internacional público, o relacionamento entre Estados nacionais não se dá diretamente por meio de seus Poderes Judiciários, a não ser nas hipóteses de terem sido celebrados acordos de cooperação jurídica internacional que prevejam tal intercâmbio, como são os tratados do Mercosul ou da União Europeia. Caso contrário, o Estado nacional é tido como um ente unitário, representado internacionalmente pelo seu órgão de relações exteriores (MELLO, Celso D. Albuquerque de. Direito internacional público. 15. ed. rev. e aum. Rio de Janeiro: Renovar, 2004. v. 1, p. 138).
} 
Por isso, a norma delimitadora da jurisdição é unilateral e exclusiva. Se o julgador que decidiu afastar a jurisdição de seu Estado decidir pela jurisdição de outro Estado para julgar a lide, isso implicaria numa usurpação da competência do segundo Estado. ${ }^{148}$

Assim, a pergunta a ser feita não é "qual a jurisdição competente", mas "se existe jurisdição do Estado acionado para decidir determinado caso concreto". 149

Este princípio é importante quando se analisa o instituto da anti-suit injunction, oriundo do common law, e que visa a promover tutelas inibitórias contra uma das partes, com o propósito de que ela deixe de promover ou desista da promoção de ações judiciais ajuizadas no estrangeiro, sob o argumento de que a jurisdição do foro é a única competente. Esse instituto, manifestamente violador do princípio da plenitudo jurisdictionis, será abordado com mais vagar oportunamente.

\subsubsection{Princípio da commitas gentium}

Trata-se de um princípio de direito que visa a regular as regras de competência internacional pelo reconhecimento de sentenças estrangeiras, o respeito às imunidades e à cooperação jurídica internacional.

O exercício da competência internacional do Estado, no dizer de José Carlos de Magalhães, deve atender às aspirações da comunidade internacional. ${ }^{150}$

O dever de cooperação entre os Estados está no próprio artigo I da Carta das Nações Unidas e, no Brasil, o princípio da cooperação se situa no artigo $4^{\circ}$, inciso IX, da Constituição Federal. O NCPC trouxe no capítulo II diversas disposições sobre a cooperação jurídica internacional (arts. 26 a 41), incorporando inclusive as disposições relativas à homologação de sentença estrangeira, antes dispostas na Resolução n. 9 do STJ.

\footnotetext{
${ }^{148}$ CORREIA, António de Arruda Ferrer. Reflexões sobre competência internacional indireta. In: Estudos vários de direito. Coimbra: Universidade de Coimbra, 1982. p. 194.

149 JATAHY, Vera Maria Barrera, Do conflito de jurisdições: a competência internacional da justiça brasileira, cit., p. 25.

${ }^{150}$ MAGALHÃES, José Carlos de. Fatores de limitação da jurisdição do Estado. Revista dos Tribunais, São Paulo, v. 88, n. 767, p. 52, set. 1999.
} 
No âmbito europeu, o sistema de cooperação judicial é bastante desenvolvido. Antes do Tratado de Maastricht conceber o espaço judiciário europeu, a Convenção de Bruxelas, de 24 de setembro de 1968, denominada "Bruxelas I", já tratava da competência judiciária e da execução de decisões em matéria civil e comercial, entre os seis Estados fundadores da Comunidade Econômica Europeia. Essa Convenção sofreu modificações por quatro convenções de adesão, por conta da entrada de novos Estados-membros na Comunidade. $^{151}$

Posteriormente, a Convenção de Lugano, de 16 de setembro de 1988, foi celebrada com o propósito de promover a extensão dos princípios consagrados na Convenção de Bruxelas aos Estados que ainda não faziam parte da União Europeia. ${ }^{152}$

Como consequência dos objetivos previstos tanto no Tratado de Amsterdã de 1999, como no Tratado de Lisboa de 2007, os instrumentos voltados à cooperação judiciária em matéria civil e comercial, que antes eram disciplinados pelas convenções, passaram a ser regidos pelos regulamentos e diretivas. ${ }^{153}$

Assim, com o Regulamento (CE) 44/2001, deu-se a transformação e o aperfeiçoamento da Convenção de Bruxelas de 1968, porém mantendo a denominação “Bruxelas I". Com a entrada em vigor do Regulamento (CE) 44/2001, a Convenção de Bruxelas de 1968 apenas continuou a ser aplicada ao Reino da Dinamarca, por força do protocolo relativo à posição desse Estado, anexo ao tratado de adesão respectivo e ao tratado que instituiu a União Europeia (art. $1^{\circ}$ e $2^{\circ}$ ), mas apenas até 2007 porque, a partir daquele ano, a Dinamarca também se submeteu ao Regulamento (CE) 44/2001. ${ }^{154}$

\footnotetext{
${ }^{151}$ A primeira delas foi a Convenção de 9 de outubro de 1978, relativa à adesão da Dinamarca, da Irlanda e do Reino Unido; a segunda foi a Convenção de 25 de outubro de 1982, relativa à adesão da Grécia; a terceira foi a Convenção de 26 de maio de 1989, assinada em San Sebastian, relativa à adesão de Espanha e de Portugal; e a última foi a Convenção de 29 de novembro de 1996, relativa à adesão da Áustria, Finlândia e Suécia. A Convenção de Bruxelas foi ainda completada pelo protocolo relativo à interpretação pelo Tribunal de Justiça das Comunidades Europeias de 30 de junho de 1971, cujo texto sofreu alterações com as convenções de adesão de novos Estados, nomeadamente em 1978, 1982, 1989 e 1996. A íntegra dos textos mencionados, como dos demais mencionados neste artigo, está disponível em: <http://www.gddc.pt/cooperacao/materia-civil-comercial/uniao-europeia.html>. Acesso em: 27 out. 2013.

152 Mas que faziam parte da Associação Europeia de Livre Comércio. Atualmente, essa associação é constituída unicamente pela Islândia, Noruega e Suíça. Em 2007, essa convenção foi substituída pela Nova Convenção de Lugano ou Lugano II.

153 RAMOS, Rui Manuel Gens de Moura. Previsão normativa e modelação judicial nas convenções comunitárias relativas ao direito internacional privado. In: Estudos de direito internacional privado e de direito processual civil internacional. Coimbra: Coimbra Editora, 2002. p. 211.

${ }^{154}$ Decisão do Conselho 2005/790/CE, de 20 de setembro de 2005.
} 
Posteriormente, o Regulamento (CE) 1.215/2012 substituiu o Regulamento (CE) 44/2001, mantendo basicamente as mesmas regras que vinham vigorando desde o estabelecimento do denominado Regime de Bruxelas de 1968 (também denominado Regime de Bruxelas-Lugano").

No âmbito do Mercosul, embora de maneira ainda inicial, vêm se desenvolvendo instrumentos de um processo civil internacional comum, a partir de uma série de acordos, sendo que um dos objetivos do Tratado de Assunção, em seu artigo $1^{\circ}$, foi o compromisso dos Estados-partes de harmonizar suas legislações, visando ao fortalecimento do processo de integração regional. Dentre os acordos já celebrados, estão: o Protocolo de Buenos Aires sobre Jurisdição Contratual, de 1994; a Convenção Interamericana sobre Cartas Rogatórias, de 1975; a Convenção Interamericana sobre Prova e Informação acerca do Direito Estrangeiro, de 1979; o Protocolo de Medidas Cautelares (Protocolo de Ouro Preto), de 1994; a Convenção Interamericana sobre Eficácia Extraterritorial das Sentenças e Laudos Arbitrais Estrangeiros, de 1979; e o Protocolo de Cooperação e Assistência Jurisdicional em Matéria Civil, Comercial, Trabalhista, Administrativa (Protocolo de Las Leñas), de 1996.

Os acordos internacionais firmados sob a égide do princípio do commitas gentium muitas vezes têm propiciado uma utilização abusiva do forum shopping, justamente como um efeito colateral da facilitação dos processos transnacionais. Isso será analisado quando do exame dos torpedos italianos, inicialmente com relação ao Regime de Bruxelas, e potencialmente com o Protocolo de Las Leñas.

\subsubsection{Princípio da autonomia da vontade}

A escolha do juízo por convenção particular entre contratantes é plenamente factível no ordenamento jurídico brasileiro, por meio da cláusula denominada "eleição de foro".

Consideradas as hipóteses de competência relativa da Justiça brasileira, previstas nos artigos 21 e 22 do NCPC, pode-se antever que são elas derrogáveis por convenção das partes. 
Morelli propôs que a validade desse espécie de convenção se baseia exclusivamente nesse critério, ou seja, excluindo-se os casos de competência absoluta (determináveis em cada Estado), as demais hipóteses seriam passíveis de convenção. ${ }^{155}$

Segundo Moacyr Amaral Santos, desde os antigos romanos se previa o forum contractus como uma possibilidade de delimitação da competência, ao lado do forum domicilii. ${ }^{156}$

No Brasil, a questão é bastante polêmica com relação ao direito material ${ }^{157}$, isto é, a possibilidade de as partes escolherem consensualmente o direito aplicado à controvérsia posta perante as cortes brasileiras. Com relação à eleição de foro, o NCPC, no artigo 22, III, expressamente admitiu a eleição de foro brasileiro para julgamento de demandas internacionais. E o artigo 25 determina o não conhecimento de demandas propostas no Brasil, oriundas de contrato com eleição de foro estrangeiro. ${ }^{158}$

Quanto à escolha do direito material, as controvérsias são vívidas. Embora Dolinger e Haroldo Valladão tenham demonstrado em inúmeras ocasiões que nosso direito manteve a autonomia da vontade no campo da lei aplicável às obrigações contratuais, ainda há forte resistência na doutrina à autonomia da vontade na escolha da lei aplicável pelas partes. ${ }^{159}$

\footnotetext{
${ }^{155}$ MORELLI, Gaetano. Trattato di diritto internazionale. Padova: CEDAM, 1938. v. 7, p. 198.

156 SANTOS, Moacyr Amaral. Primeiras linhas de direito processual civil. 5. ed. São Paulo: Saraiva, 1977. v. 1, p. 206. Segundo o autor, o instituto da eleição de foro tomou grande impulso na Idade Média, como decorrência do desenvolvimento do comércio.

${ }^{157}$ Quanto às regras de direito material, a aplicação do direito estrangeiro pelas cortes brasileiras não depende de ser invocada por uma das partes, na medida que as regras de direito internacional privado contidas na LINDB são imperativas: "A lei do país em que for domiciliada a pessoa determina as regras sobre o começo e o fim da personalidade, o nome, a capacidade e os direitos da família" (art. $7^{\circ}$ ); "para qualificar os bens e regular as relações a eles concernentes aplicar-se-á a lei do país em que estiverem situados" (art. $8^{\circ}$ ); "para qualificar e reger as obrigações, aplicar-se-á a lei do país em que se constituírem" (art. 9); "a sucessão por morte ou por ausência obedece à lei do país em que se constituírem” (art. 10); "quando, nos termos dos artigos procedentes, se houver de aplicar a lei estrangeira, ter-se-á em vista a disposição desta sem considerar-se qualquer remissão por ela feita a outra lei” (art. 16).

${ }^{158}$ Gustavo Monaco lembra que as partes podiam transcrever a lei material estrangeira no contrato, ou mesmo prever a aplicação da lei estrangeira quando tiverem escolhido a arbitragem como forma de resolução das futuras controvérsias, como duas modalidades de se efetivar a autonomia da vontade na escolha da lei aplicável. (MONACO, Gustavo Ferraz de Campos, Le droit applicable par la Cour: une question de droit international public ou de droit international privé harmonisé?, cit.).

159 DOLINGER, Jacob. Direito internacional privado: contratos e obrigações no direito internacional privado. Rio de Janeiro: Renovar, 2007. p. 456. Valladão é contundente nesse sentido: "Insistiremos mais uma vez no princípio da autonomia da vontade, para não dizer, simplisticamente, que apesar de secular vigência no direito brasileiro (já estava prevista no Reg. 737 de 1850, em Freitas, Esboço, art. 32, e todos os Projetos e na Introdução, art. $8^{\circ}$, fine e 13) teria desaparecido porque a ele não se referira, categoricamente, o art. $9^{\circ}$, caput, da Lei de Introdução." (VALLADÃO, Haroldo. Direito internacional privado. Rio de Janeiro: Freitas Bastos, 1983. v. 1, p. 185). No mesmo sentido: STRENGER, Irineu,
} 
Diversos tratados internacionais têm sido celebrados no sentido de proteger a autonomia das partes na escolha da lei aplicável, tais como a Convenção de Roma sobre a Lei Aplicável às Obrigações Contratuais, de 1980, a Convenção da ONU sobre os Contratos de Compra e Venda Internacional de Mercadorias (CISG), de 1980, a Convenção de Haia sobre a Lei Aplicável aos Contratos de Venda Internacional de Mercadorias, de 1986, a Convenção Interamericana sobre Direito Aplicável aos Contratos Internacionais (CIDIP V), de 1994. Tendo o Brasil ratificado a CISG (em 2013), há que se admitir que a escolha da lei aplicável nos contratos internacionais está reconhecida no ordenamento brasileiro, ao menos no que diz respeito à compra e venda internacional de mercadorias entre os países signatários dessa convenção.

Até o advento do Novo Código de Processo Civil, promulgado em 16 de março de 2015 e em vacatio legis por um ano, a possibilidade de escolha de foro pelos contratantes sempre gerou muita incerteza, diante da jurisprudência vacilante dos tribunais brasileiros.

Em síntese, discutia-se a possibilidade de se conferir eficácia à eleição de um foro estrangeiro quando o Judiciário brasileiro também era competente para julgar a causa, nas hipóteses de competência concorrente do artigo 88 do CPC. A questão era saber se a vontade das partes poderia afastar a jurisdição brasileira quando tivessem escolhido um tribunal estrangeiro para, com exclusividade, apreciar a disputa.

De um modo geral, a doutrina se posicionou a favor da liberdade de escolha das partes quanto à eleição de um tribunal estrangeiro, nas hipóteses de competência concorrente da Justiça brasileira. ${ }^{160}$

Na União Europeia, o Regulamento (EU) 1.215/2012, relativo à competência judiciária, ao reconhecimento e à execução de decisões em matéria civil e comercial, em seu artigo 25 deu plena liberdade às partes para que escolhessem de comum acordo o tribunal competente para apreciar suas demandas, desde que não se trate das hipóteses de competência exclusiva de algum outro tribunal. Do mesmo modo, no âmbito do Mercosul,

Autonomia da vontade em direito internacional privado, cit. Em sentido contrário: CASTRO, Amilcar de, Direito internacional privado, cit., v. 1, p. 444.

${ }^{160}$ ARAÚJO, Nádia de. Direito internacional privado: teoria e prática brasileira. 4. ed. atual. e ampl. Rio de Janeiro: Renovar, 2008. p. 223; TIBURCIO, Carmen. A eleição de foro estrangeiro e o judiciário brasileiro. Revista de Direito de Estado, Renovar, n. 12, p. 379, out./dez. 2008; e CARNEIRO, Athos Gusmão, Jurisdição e competência: exposição didática, área do direito processual civil, cit., p. 50. 
o Protocolo de Buenos Aires sobre jurisdição internacional em matéria contratual, em seu artigo $4^{\circ}$ reconhece às partes o mesmo direito. ${ }^{161}$

A jurisprudência brasileira, ao contrário, titubeou no reconhecimento da autonomia da vontade na eleição de foro em contratos internacionais.

Em 2011, a $3^{\text {a }}$ Turma do Superior Tribunal de Justiça (STJ), no ED ED REsp n. 1.1597.896/PE, entendeu que "a cláusula de eleição de foro não afasta a competência internacional concorrente da autoridade brasileira, nas hipóteses em que a obrigação deva ser cumprida no Brasil (art. 88, II, do CPC)". No mesmo ano, a $4^{\text {a }}$ Turma do mesmo tribunal, no REsp n. 1.168.547/RJ, considerou que:

[...] a cláusula de eleição de foro existente em contrato de prestação de serviços
no exterior, portanto, não afasta a jurisdição brasileira". Um curioso voto vista
nesse acordão afirmou que "tem competência concorrente a Justiça Brasileira
para julgar ação de indenização por uso indevido de imagem na hipótese em que
brasileira alega que empresa espanhola, após o término de contrato temporário
celebrado fora do Brasil para realização de shows no exterior, divulgou fotos
suas sem prévia autorização em site da Espanha, e ainda que o contrato tenha
previsto este país como o foro de eleição para eventual controvérsia entre as
partes, pois o direito fundamental à dignidade da pessoa humana, que inclui o
direito à imagem, prevalece sobre qualquer outro direito, e porque a autora reside
no Brasil, aplicando-se o artigo 88 do CPC.

Em sentido contrário, em 2010, a $3^{\mathrm{a}}$ Turma desse tribunal, no REsp n. 1.177.915/RJ, entendeu que "a eleição de foro estrangeiro é válida, exceto quando a lide envolver interesses públicos", citando o precedente de 2005 daquela Turma (REsp n. 242.383/SP).

A posição conflituosa da jurisprudência do STJ tornou-se ainda mais decrépita, na medida que a Lei de Arbitragem, em vigor no Brasil desde 1996, foi reconhecida como constitucional pelo Supremo Tribunal Federal (STF) em sua integralidade. Dessa forma, podiam as partes escolher a lei e a corte arbitral que desejassem, mas não o foro

\footnotetext{
${ }^{161}$ Interessante notar que o artigo $1^{\circ}$ desse Protocolo, alínea "b", in fine, coloca uma condição que em princípio poderia limitar a validade da cláusula de eleição de foro: "e [desde que] exista uma conexão razoável segundo as normas de jurisdição deste Protocolo". Possivelmente essa asserção relaciona-se ao princípio do fóorum exorbitante, já tratado anteriormente neste trabalho.
} 
estrangeiro. Essa posição foi classificada por Carmen Tiburcio como "incoerente"162, e por Paulo Casella como "curiosa". ${ }^{163}$

Em boa hora, portanto, os artigos 22, III e 25, do NCPC. ${ }^{164}$

\subsubsection{Princípios negativos de incidência e reconhecimento da jurisdição internacional}

\subsubsection{Princípio da imunidade de jurisdição}

Este princípio afasta a jurisdição de um determinado Estado em razão da qualidade do réu. Sendo os Estados iguais entre si, não haveria como um julgar o outro, sem que violassem reciprocamente suas respectivas soberanias. Consequentemente, o chefe de Estado detém imunidade, na medida que representa seu Estado, assim como sua equipe de

diplomatas, embaixadores e demais membros do aparato estatal. ${ }^{165}$

O princípio decorre do antigo adágio medieval par in parem non habet imperium, invocado por senhores feudais e adaptado no século XVIII aos novos Estados soberanos, pela regra atualizada par in par non habet iudicium. ${ }^{166}$

A extensão atribuída à imunidade se reduz a alternativa simples: ou será afirmada como absoluta, excluindo-se qualquer intervenção do juiz ou da autoridade administrativa de um Estado, em qualquer controvérsia, ou será relativa, comportando exclusões, com a necessidade de se determinar o conteúdo e a extensão dessas exclusões.

\footnotetext{
162 TIBURCIO, Carmen, A eleição de foro estrangeiro e o judiciário brasileiro, cit., p. 383.

${ }^{163}$ CASELLA, Paulo Borba. Autonomia da vontade, arbitragem comercial internacional e direito brasileiro. In: TIBURCIO, Carmen; BARROSO, Luis Roberto. O direito internacional contemporâneo: estudos em homenagem ao professor Jacob Dolinger. Rio de Janeiro: Renovar, 2006. p. 743.

${ }^{164}$ Como dito por Gustavo Monaco, ao não reconhecer expressamente a validade da cláusula de eleição de foro estrangeiro, o CPC de 1973 criou o risco de ocorrência de julgamentos contraditórios, pela possibilidade de ocorrer a lispendência internacional (MONACO, Gustavo Ferraz de Campos, Le droit applicable par la Cour: une question de droit international public ou de droit international privé harmonisé?, cit.).

${ }^{165}$ SOARES, Guido Fernando Silva. Das imunidades de jurisdição e de execução. Rio de Janeiro: Forense, 1984. p. 41.

166 ACCIOLY, Hildebrando; SILVA, Geraldo Eulálio do Nascimento e; CASELLA, Paulo Borba. 19. ed. Manual de direito internacional público. São Paulo: Saraiva, 2011. p 378.
} 
No Brasil, a partir do julgamento da AC n. 9.696-3/SP (caso "Genny"), o STF passou a restringir a imunidade de Estados estrangeiros para casos que não sejam negociais, mantida a imunidade nos atos de império. Assim, em casos de dívidas oriundas de relações trabalhistas, por exemplo, ou imobiliárias, não haveria imunidade.

O STF, no AgR RE n. 222.368-4, decidiu que o privilégio resultante da imunidade não inibiria a Justiça brasileira de exercer jurisdição nos processos de conhecimento instaurados contra Estados estrangeiros, mesmo nos casos de atos de imperium, não cabendo porém o cumprimento das sentenças contra esses mesmos Estados no Brasil. Isso abriria a hipótese de remessa da coisa julgada para execução no território estrangeiro, com a homologação de sentença brasileira no estrangeiro.

Seria uma hipótese de exceção ao princípio da imunidade de jurisdição, pelo princípio da submissão. Tanto no caso AgR RE n. 222.368-4 mencionado acima, que envolve o pedido de condenação dos Estados Unidos ao pagamento da recompensa de US\$ 25 milhões pela suposta indicação do esconderijo de Saddam Hussein por um vidente brasileiro, como no caso do RO n. 64/SP (STJ), em que um francês naturalizado brasileiro propôs uma ação de indenização contra a Alemanha, por danos infringidos a ele pelo regime nacional-socialista em solo francês, abriu-se a possibilidade de os Estados estrangeiros - voluntariamente - submeterem-se à jurisdição brasileira.

Dessa forma, o princípio da imunidade de jurisdição, segundo construção jurisprudencial brasileira, passa a ser aplicado após a constatação de que os Estados estrangeiros não reconheçam expressamente a jurisdição brasileira, ou, ao contrário, a ela se submetam. Nesse caso, o princípio da imunidade de jurisdição será suplantado pelo princípio da submissão.

Como ficou consignado no RO n. 64/SP, em 2008:

[...] a imunidade de jurisdição não representa uma regra que automaticamente deva ser aplicada aos processos judiciais movidos contra um Estado Estrangeiro. Trata-se de um direito que pode, ou não, ser exercido por esse Estado. Assim, não há motivos para que, de plano, seja extinta a presente ação. Justifica-se a 
citação do Estado Estrangeiro para que, querendo, alegue seu interesse de não se submeter à jurisdição brasileira, demonstrando se tratar, a hipótese, de prática de atos de império que autorizariam a invocação desse princípio.

É interessante mencionar que no passado houve um intenso debate no STF sobre a possibilidade de uma parte brasileira afastar a homologação de sentença estrangeira proferida contra si, baseada no fato de que não teria "aceitado" a jurisdição alienígena, justamente pelo princípio da submissão.

Esse debate se deu na SEC n. 4.415-5/EUA, em que a empresa mineradora peruana Minpeco S/A requereu a homologação de uma sentença estrangeira oriunda dos Estados Unidos, em que obteve a condenação do empresário Naji Robert Nahas ao pagamento de mais de US\$ 300 milhões, por suposta manipulação do mercado internacional de prata. A controvérsia cingiu-se à competência jurisdicional dos Estados Unidos, pelo fato de o réu Naji Nahas ter domicílio no Brasil e haver expressamente recusado a jurisdição estrangeira $^{167}$ perante a corte americana. Em outras palavras, a defesa de Naji Hahas invocou o princípio da imunidade de jurisdição, pelo fato de expressamente ter-se recusado a se submeter a uma corte alienígena.

Naji Nahas baseou-se no precedente da SE n. 2.114/EUA, julgada pelo plenário do STF, em que se aplicou o princípio da submissão de maneira ampla: entendeu a corte constitucional, naquela oportunidade, que somente seriam homologadas sentenças estrangeiras, desde que a parte brasileira tivesse voluntariamente se submetida à jurisdição estrangeira. Via de consequência, bastaria a manifestação da parte brasileira de que não aceitava a jurisdição estrangeira, quando de sua defesa no exterior, que a futura sentença não seria homologável no Brasil. Essa posição acabou sendo revista na SEC n. 4.4155/EUA, e confirmou-se a homologação da sentença condenatória proferida nos Estados Unidos contra Naji Nahas, não mais havendo que se falar em submissão voluntária como elemento do princípio da imunidade, como uma das formas de se excluir a eficácia da jurisdição internacional no Brasil.

\footnotetext{
${ }^{167}$ Outro ponto curioso do recurso, que não guarda relação com o presente trabalho, foi a alegação de que a sentença cível estrangeira violava a ordem pública brasileira, por ausência de motivação, na medida que fora ela proferida por um júri civil.
} 


\subsubsection{Princípio da efetividade}

Segundo Athos Gusmão Carneiro, o exercício da jurisdição encontra limites no princípio da efetividade, ou seja, o juiz brasileiro somente deveria atuar naquelas causas em que houvesse possibilidade de se tornar efetiva (fazer-se cumprir) sua sentença. ${ }^{168}$

Vera Jatahy vai no mesmo sentido, definindo o princípio da efetividade pelo aspecto negativo, na medida que o Estado deve abster-se de julgar a demanda, caso a sentença que vier a produzir não tenha como ser reconhecida onde deva produzir seus efeitos. Assim, segundo a autora, o fundamento do princípio encontra-se na inutilidade de um julgamento prolatado em tais circunstâncias. ${ }^{169}$

No HC n. 102.041/SP, proposto por Boris Berezovsky perante o STF, foi requerida uma tutela contra a missão diplomática da Federação Russa no Brasil, para que ela fosse impedida de entregar ao Ministério Público russo ("Prokuratura") peças e elementos probatórios que tinham sido retirados do paciente. E caso a embaixada russa tivesse remetido o material para a "Prokuratura", requereu Boris Berezovsky que o material fosse devolvido à Embaixada russa no Brasil, devendo lá permanecer. O STF denegou a ordem, dentre outras razões, pelo princípio da efetividade: eventual tutela não seria exequível contra o corpo consular russo. Porém, pela natureza do pedido, o fator impeditivo parece ter sido o princípio da imunidade de jurisdição, como visto anteriormente, e não o princípio da efetividade. A consideração de que a busca dos hardwares de Berezovsky pudesse ser considerada, à luz do direito brasileiro, ilegal, poderia em tese anular eventual prova contra o paciente no âmbito da Federação Russa, pelo princípio dos frutos da árvore envenenada, fato esse não enfrentado pela corte brasileira.

Segundo José Ignácio Botelho de Mesquita, o princípio da efetividade atua para definir as hipóteses em que, a despeito de estar a causa incluída no rol que admite a competência concorrente da Justiça brasileira, a autoridade judiciária deverá se declarar internacionalmente incompetente para dela conhecer. Isso ocorre porque à soberania

\footnotetext{
${ }^{168}$ CARNEIRO, Athos Gusmão, Jurisdição e competência: exposição didática, área do direito processual civil, cit., p. 65.

169 JATAHY, Vera Maria Barrera, Do conflito de jurisdições: a competência internacional da justiça brasileira, cit., p. 38. Trata-se de uma interpretação a contrario sensu dos artigos 89 do CPC de 1973 e 23 do NCPC.
} 
nacional somente interessam: (a) as causas cuja decisão demande a aplicação do direito nacional, independentemente da nacionalidade do território onde se devam produzir os efeitos da sentença; (b) as causas cujas sentenças devam produzir efeitos dentro do território do Estado, independentemente da nacionalidade do direito aplicável na sua decisão; e (c) os processos de execução de sentença ou títulos executivos extrajudiciais que demandem a prática de atos executórios sobre pessoas ou bens que, por estarem no território nacional, se acham submetidos ao ordenamento jurídico nacional. ${ }^{170}$

O princípio da efetividade, dentro do contexto da jurisdição internacional, parece estar ligado à própria condição da ação: o interesse de agir em um litígio envolvendo parte ou partes estrangeiras.

$\mathrm{O}$ interesse de agir relaciona-se à utilidade do provimento jurisdicional, indicada pela necessidade e adequação, aliada à existência de uma pretensão objetivamente razoável, que possa trazer proveito do fato de se propor ou contestar uma ação, assegurando-se ou restabelecendo-se uma relação jurídica.

Em tempos em que se busca dar maior efetividade ao processo, enfatizando sua instrumentalidade, deve-se evitar e impedir que o processo inviável exista.

Nas palavras de José Roberto dos Santos Bedaque, a eficácia do sistema processual será medida em função de sua utilidade para o ordenamento jurídico material e para a pacificação social. Não interessa, portanto, uma ciência processual conceitualmente perfeita, mas que não consiga atingir os resultados a que se propõe. "Menos tecnicismo e mais justiça, é o que se pretende." ${ }^{171}$

Dessa forma, numa situação em que a futura sentença tenha que ser executada no estrangeiro, cabe perguntar se ela será passível de lá ser executada, quando da própria propositura da ação.

\footnotetext{
${ }^{170}$ MESQUITA, José Ignácio Botelho de. Da competência internacional e dos princípios que a informam. Revista de Processo, São Paulo, Revista dos Tribunais, v. 13, n. 50, p. 51, abr./jun. 1988.

${ }^{171}$ BEDAQUE, José Roberto dos Santos, Direito e processo: influência do direito material sobre o processo, cit., p. 16.
} 
Como exemplo, sentenças condenatórias baseadas nas leis antidifamação inglesas (libel tourism) deixaram de ser reconhecidas em Nova York, por supostamente violarem a $1^{\text {a }}$ Emenda à Constituição Americana (right to free speach ${ }^{172}$. Esse assunto será retomado oportunamente.

Outro exemplo é a recusa dos tribunais alemães em reconhecer sentenças cíveis condenatórias americanas baseadas na doutrina dos danos punitivos (punitive damages), posto que tal doutrina é uma instituição desconhecida na Alemanha. ${ }^{173}$

Ambas as demandas poderiam deixar de ter seu trâmite permitido na origem, isto é, na Inglaterra ou nos Estados Unidos, na medida que o princípio da efetividade se apresentasse consolidado respectivamente na jurisprudência nova-iorquina (libel tourism) e alemã (punitive damages). Isso porque uma eventual ação de indenização proposta na Inglaterra, e baseada no libel tourism, cuja execução tivesse que se dar em Nova York, poderia ser julgada extinta na Inglaterra, posto que a sentença não seria reconhecida em Nova York. Do mesmo modo, uma ação de indenização proposta nos Estados Unidos, baseada no pedido de punitive damages, e cuja futura execução tenha que ser proposta na Alemanha, seria igualmente inútil. Pelo princípio da efetividade, as ações poderiam ser julgadas extintas prematuramente, já que ausente o interesse de agir do demandante.

O princípio da efetividade parece ser uma importante válvula de controle de processos transnacionais, evitando-se eventuais dilações indevidas, embora não pareça haver um controle tão sistematizado de sua incidência na tradição brasileira.

Com grande repercussão no common law, este princípio costuma servir como base da doutrina do forum non conveniens, como será tratado oportunamente.

\subsubsection{Princípio da jurisdição exorbitante}

Trata-se de um princípio controvertido, derivado do common law. Basicamente, a doutrina internacional considera razoável que um foro aprecie uma lide, na hipótese em

172 STAVELEY-O'CARROLL, Sarah. Libel tourism laws: spoiling the holiday ad saving the First Amendment? New York University Journal of Laws \& Liberty, v. 4, No. 3, p. 252-264, Feb. 2009.

${ }^{173}$ BEHR, Volker. Punitive damages in America and German Law: tendencies towards approximation of apparently irreconcilable concepts. Chicago-Kent Law Review, Chicago, v. 78, n. 1, p. 107, Jan. 2003. 
que o caso analisado apresente uma vinculação suficiente com o Estado a que pertençam os tribunais vinculados ao julgamento. Portanto, em sentido oposto, os foros exorbitantes seriam aqueles que se caracterizaram por acumular um grande volume de competência internacional, com o propósito de beneficiar exageradamente os nacionais do Estado competente. ${ }^{174}$

No âmbito interno dos Estados Unidos, cada um de seus entes federativos tem a prerrogativa de reconhecer as sentenças estrangeiras que lhe sejam apresentadas, havendo entre todos eles um consenso quanto ao não reconhecimento, baseado no fato de que a sentença estrangeira tenha sido obtida em "unreasonable jurisdictional basis", isto é, em jurisdição exorbitante. ${ }^{175}$

A razoabilidade ou não de um foro parece ser aferida pela proximidade ou conexão substancial da causa com o respectivo foro. Significa que para o desiderato de determinar se um tribunal possui jurisdição sobre a matéria, deve-se verificar a existência de um mínimo de contato razoável entre o caso analisado e a sede do tribunal. Assim, apresentam eles um elemento de proximidade e neutralidade genérica que não aparece nas jurisdições exorbitantes. ${ }^{176}$

Tal controle permite ao tribunal rechaçar jurisdições consideradas abusivas ou exorbitantes.

Muito embora tais definições pareçam, à primeira vista, subjetivas em demasia, é forçoso reconhecer que algumas regras de competência internacional possam de fato proteger uma das partes exageradamente, muito embora não violem as regras de competência do Estado em que se pretenderá fazer uso da sentença ali obtida.

\footnotetext{
${ }^{174}$ GUERRA, Marcel Vitor de Magalhães; MOSCHEN, Valesca Raizer Borges. Processo civil transnacional: a caminho de uma sistematização dos princípios de competência internacional: reflexos de um novo paradigma axiológico face à crise metodológica positivista. In: ENCONTRO NACIONAL DO CONPEDI: as dimensões da personalidade na contemporaneidade, 18., 2009, Maringá, PR. Anais... Florianópolis: Fundação Boiteux, 2009. p. 4.797-4.816.

${ }^{175}$ VON MEHREN, Arthur Taylor. Recognition and enforcement of foreign judgments: a new approach for the Hague Conference? Law and Contemporary Problems, Durham, NC, v. 57, n. 3, p. 272, Summer 1994.

${ }^{176}$ RUSSELL, Kathryn A. Exorbitant jurisdiction and enforcement of judgments: the Brussels system as an impetus for the United States action. Syracuse Journal of International Law and Commerce, v. 19, p. 2, Spring, 1993.
} 
Especificamente no caso brasileiro, as regras dos artigos 22 e 23 do NCPC preveem, sem qualquer limitação, a homologação de sentenças estrangeiras nas situações previstas. No âmbito do direito internacional público, no caso Lótus, a Corte Internacional de Justiça reconheceu em 1927 que o Estado tem a plena prerrogativa de definir sua própria competência, sem limitações ${ }^{177}$, decisão merecedora de diversas críticas. ${ }^{178}$

Há de existir uma apropriada e razoável base jurisdicional para reconhecer a seriedade da jurisdição exercida por um juiz estrangeiro. Para que um tribunal exerça de forma razoável sua jurisdição, parece necessário que exista uma genuína e substancial conexão entre o caso e o tribunal.

Embora essa discussão tenha por base a doutrina do forum non conveniens, em que há grande discricionariedade do julgador em não conhecer de demandas com elementos internacionais, é possível que o princípio do fórum exorbitante possa ser aplicado pelo julgador como uma razão válida para não se homologar uma sentença estrangeira.

Definido o conceito de fórum exorbitante, é importante compreender o que a doutrina internacional define por exorbitância em matéria de competência internacional.

De um modo geral, doutrinadores oriundos da tradição do common law têm apontado como principais critérios definidores de um fórum exorbitante: (1) a nacionalidade; (2) a existência de bens do demandado no território do foro; e (3) a existência de "negócios" do demandado no foro. ${ }^{179}$

A competência internacional baseada exclusivamente na nacionalidade, sem levar em conta o domicílio das partes, pode ser encontrada no artigo 14 do Código Civil

\footnotetext{
${ }^{177}$ Corte Internacional de Justiça, Série A, n. 10, de 1927.

178 HANDEYSIDE, Hugh. The lotus principle in ICJ jurisprudence: was the ship ever afloat? Michigan Journal of International Law, Ann Arbor, Mich., University of Michigan Law School, v. 29, No. 1, p. 7194, Fall 2007.

${ }^{179}$ CLERMONT, Kevin M.; PALMER, John R. B. Exorbitant jurisdiction. Maine Law Review, v. 58, No. 2, p. 474-505, 2006; DEKKER, Bart. Exorbitant jurisdiction: law as an off-track 4by4. Comparative Civil Procedural Law Paper, v. 2, p. 2, 2013; e MOSS, Giuditta Cordero. Between private and public international law: exorbitant jurisdiction as illustrated by the Yukos Case. Review of Central and East European Law, Dordrecht; Boston: Martinus Nijhoff Publishers, v. 32, p. 11, 2007.
} 
francês ${ }^{180}$. Esse artigo permite aos cidadãos franceses a possibilidade de ingressar nas cortes nacionais mesmo quando a lide não tenha qualquer relação com a França e as partes nunca tenham sequer pisado em solo francês.

Assim, um francês pode processar um brasileiro em Paris por conta de uma agressão sofrida na cidade do Rio de Janeiro ou em Ulan Bator, na Mongólia. E o artigo 15 do Código Civil francês define tal competência como "exclusiva", fazendo com que eventuais sentenças condenatórias proferidas em jurisdições outras que não a França não sejam passíveis de serem homologadas, por conta de tal competência exclusiva. ${ }^{181}$

A competência internacional baseada na existência de bens do demandado no foro, além da Suécia (já mencionado como o "guarda-chuva sueco), também é encontrada na Alemanha. O Código de Processo Civil alemão, em seu artigo 23, prevê que os tribunais alemães terão competência internacional sobre qualquer réu que possua ativos na Alemanha, independentemente de seus valores. ${ }^{182}$

Como no caso francês, o critério definidor da competência internacional alemã não leva em conta o domicílio de quaisquer das partes, ou a existência de vinculação entre a relação jurídica tratada na demanda e o território alemão. Assim, em tese, um brasileiro que tenha esquecido um violão ou um pandeiro em Düsseldorf durante uma conexão de voo poderá ser demandado nos tribunais alemães, por conta de um acidente de carro ocorrido em Osasco.

\footnotetext{
180 “Article 14. L'étranger, même non résidant en France, pourra être cité devant les tribunaux français, pour l'exécution des obligations par lui contractées en France avec un Français; il pourra être traduit devant les tribunaux de France, pour les obligations par lui contractées en pays étranger envers des Français."

181 "Article 15. Un Français pourra être traduit devant un tribunal de France, pour des obligations par lui contractées en pays étranger, même avec un étranger". Esse dispositivo foi interpretado em 2006 pela Cour de Cassation como uma hipótese de competência concorrente (e não obrigatória) da Justiça francesa, a não ser na hipótese de que a escolha do tribunal estrangeiro tenha se dado por fraude à lei $\left(B u l l .2006, \mathrm{I}, \mathrm{n}^{\circ} 254\right.$, pourvoi $\mathrm{n}^{\circ}$ 04-12.777, Rapport annuel de la Cour de cassation 2006, p. 463. Fiche Pedagogique Virtuelle, Seance n. 10, les articles 14 et 15 du Code Civil, 10/12/2006, Faculté de Droit de Lyon. Disponível em: $<$ http://www.facdedroit-lyon3.com>. Acesso em: 21 jun. 2015.

182 "Section 23. Specific jurisdiction of assets and of an object. For complaints under property law brought against a person who has no place of residence in Germany, that court shall be competent in the jurisdiction of which assets belonging to that person are located, or in the jurisdiction of which the object being laid claim to under the action is located. Where claims are concerned, the debtor's place of residence and, in cases in which an object is liable for the claims as collateral, the place at which the object is located shall be deemed to be the location at which the assets are located."
} 
No âmbito do direito empresarial, sendo factível que qualquer grande empresa transnacional detenha algum ativo na Alemanha, as cortes alemãs possuem uma verdadeira jurisdição universal.

O NCPC, no artigo 22, inciso I, alínea "b", prevê a competência das cortes brasileiras para processar e julgar ações de alimentos, nos casos em que "o réu mantiver vínculos no Brasil, tais como posse ou propriedade de bens, recebimento de renda ou obtenção de benefícios econômicos". A locação "tais como" prevista na alínea "b" do referido artigo leva à ideia de que a existência de quaisquer bens (sejam eles móveis ou imóveis, corpóreos ou incorpóreos, divisíveis ou indivisíveis etc.), promove a competência da Justiça brasileira para cobrança de alimentos do réu. Parece ser o caso de um critério de competência "guarda-chuva" brasileiro, seguindo a mesma disposição contida no artigo $8^{\circ}$ da Convenção Interamericana sobre Obrigações Alimentares, em vigor no Brasil desde 1989. ${ }^{183}$

Por fim, a competência internacional baseada na existência de "negócios" do demandado no foro, sem que tais negócios tenham qualquer relação com a demanda, é encontrada em certos Estados federativos dos Estados Unidos, baseados em regras denominadas “long arm statutes". A partir dessas regras, tais Estados exercem a jurisdição internacional sobre demandas em que o réu tenha qualquer atividade econômica no foro, mesmo que tais atividades não tenham qualquer relação com a causa. ${ }^{184}$

\footnotetext{
${ }^{183}$ Sem dúvida, a existência de bens do devedor de alimentos no foro é um critério que facilita a efetividade o provimento jurisdicional. A Convenção de Nova York sobre Prestação de Alimentos no Estrangeiro, em vigor no Brasil desde 1958, previa apenas o domicílio do demandante ou do demandado como hipóteses de jurisdição internacional. Curiosa é a situação dos alimentos civis (que servem à manutenção do mesmo padrão de vida que desfrutava o alimentado em momento anterior), reconhecidos pelo direito brasileiro, em detrimento dos alimentos naturais (que servem à subsistência do alimentado): a eventual sentença brasileira que condenar o alimentante ao pagamento dos alimentos civis pode deixar de ser reconhecida em outras jurisdições que primem pela igualdade de gêneros, pelo filtro da ordem pública (MONACO, Gustavo Ferraz de Campos, Le droit applicable par la Cour: une question de droit international public ou de droit international privé harmonisé?, cit.).

${ }^{184}$ Num primeiro momento, pode-se considerar que esse critério de fixação da competência internacional "exagerado" encontra paralelo no Brasil, o que não é verdade. Em se tratando de pessoas jurídicas de direito privado, o domićlio corresponde ao local em que funcionarem as respectivas diretorias e administrações, ou no qual tiverem elas eleito domicílio especial na forma do estatuto ou atos constitutivos (art. 75, IV, do CC). E, por mais que a administração ou diretoria tenha sua sede no estrangeiro, o local de seu substabelecimento no Brasil, na forma de sua filial, agência ou sucursal, é considerado o domicílio da pessoa jurídica estrangeira (arts. 75, $\S 2^{\circ}$, do $\mathrm{CC}$ e 12 da LINDB), especificamente "no tocante às obrigações contraídas por suas agências". Isso significa que a redação do parágrafo único do artigo 88 do CPC de 1973, que trata do domicilio da pessoa jurídica estrangeira que tenha representação no Brasil, reconhece a competência internacional da Justiça brasileira, desde que a demanda tenha relação direta com atos ou fatos relacionados diretamente a essa mesma representação no país. Dessa forma, muito embora a
} 
No caso Bryant $v$. Finnish National Airlines, bastante citado pela doutrina americana, um autor nova-iorquino propôs uma ação condenatória contra a companhia aérea finlandesa em Nova York, baseado em prejuízos sofridos em Paris, pelo fato de a companhia possuir uma sala comercial e meia em Nova York, onde alguns funcionários se ocupavam de tarefas de publicidade. Até então, nunca houvera antes qualquer voo daquela companhia aérea para os Estados Unidos. ${ }^{185}$

Desde 1962 a Conferência da Haia, por meio de sucessivas tentantivas de sistematizar a colaboração dos Estados no reconhecimento e execução de sentenças estrangeiras, tem apontado ainda as seguintes situações que configurariam jurisdições exorbitantes: ${ }^{186}$

a) domicílio habitual ou esporádico do autor, exceto em casos específicos;

b) o local onde o réu recebeu a notificação, intimação ou citação, estando ali apenas de passagem;

c) quando o credor preenche a jurisdição competente em faturas ou documentos de cobrança, unilateralmente;

d) presença acidental de produtos fabricados pelo réu em jurisdições não previstas ou não buscadas por ele, e que supostamente tenham causado dano ao reclamante;

e) a concessão de medidas cautelares que, por sua vez, preveniriam a jurisdição para a lide principal;

f) a homologação de sentenças estrangeiras ou o início da execução de títulos executivos estrangeiros, que por sua vez preveniriam a jurisdição para outras lides.

Todas essas hipóteses discutidas no âmbito das convenções da Haia parecem ter em comum o fato de favorecerem os autores em demasia.

citação da pessoa jurídica com sede no exterior possa ser realizada no Brasil, na pessoa de seus representantes aqui situados (art. 12, VIII, do CPC de 1973), a competência internacional da Justiça brasileira não decorre da mera existência de tais representantes, mas sim do preenchimento das hipóteses previstas no artigo 88 do CPC 1973.

185 “ 1965,15 New York, $2^{\text {nd }} 426,432,260$ N.Y.S. $2^{\text {nd }} 625,629,208$ N.E. $2^{\text {nd }} 439,441$ (1965)" (STRUYVEN, Olivia. Exorbitant jurisdiction in the Brussels Convention. Jura Falconis, Leuven, Bélgie, Katholieke Universiteit Leuven, v. 35, No. 4, p. 522, 1998).

186 KESSEDJIAN, Catherine. International jurisdiction and foreign judgments and commercial matters. Preliminary Document n. 7 of April 1997 for the attention of the Special Commission of June 1997 on the question of jurisdiction, and recognition and enforcement of foreign judgments in civil and commercial matters. Disponível em: <http://www.hcch.net/upload/wop/jdgm_pd7.pdf>. Acesso em: 25 maio 2014. 
Porém, a convenção nunca entrou em vigor, pois apenas Chipre, Holanda, Portugal e Albânia assinaram seu texto. ${ }^{187}$

\subsection{Forum game: a teoria dos jogos e a racionalidade na escolha da jurisdição mais favorável}

Uma vez estabelecidas as premissas sobre a jurisdição internacional e os princípios que a informam, parece importante compreender as razões que levariam as partes a preferir uma jurisdição estrangeira, ao invés da nacional. ${ }^{188}$

Embora tal análise fuja do campo estritamente jurídico, a escolha da jurisdição do conflito irá desempenhar uma série de consequências sobre a relação jurídica processual estabelecida entre as partes.

Há diferenças entre as jurisdições, assim como há entre seus povos, suas economias e suas estruturas estatais. Se nasce um conflito, e há possibilidade de se discutir esse conflito em mais de uma jurisdição, parece natural que se sopesem as possibilidades. Quando uma parte vence uma disputa, isso significa uma perda de poder da outra parte. O poder representa, portanto, um fenômeno relacional, no qual há a chance de impor a própria vontade, mesmo contra oposições. ${ }^{189}$

Seguindo as regras civilizadas de resolução de conflitos privados por meio da jurisdição estatal, há o processo civil. Já em 1959, Calamandrei ${ }^{190}$ estudava o processo "come giuoco", e estabelecia diversos parâmetros de utilização da dinâmica processual como forma explícita de se obter vantagens de per si, não obstante a solução jurídica final:

\footnotetext{
187 Ver: INFORMATION concerning the Hague Conventions on Private International Law. Netherlands International Law Review, Dordrecht, Netherlands, Martinus Nijhoff Publishers, v. 36, No. 2, p. 204-205, Aug. 1989; RODAS, João Grandino; MONACO, Gustavo Ferraz de Campos. Conferência da Haia de Direito Internacional Privado: a participação do Brasil. Brasília: Fundação Alexandre de Gusmão, 2007. p. 282.

${ }^{188}$ Evidentemente, exclui-se na presente análise as intenções de fraude à lei ou as exceções de ordem pública. Ver: BAPTISTA, Luiz Olavo. Aplicação do direito estrangeiro pelo juiz brasileiro. Revista de Informação Legislativa, n. 142, p. 270, abr./jun. 1999.

${ }^{189}$ HÖFFE, Otfried, A democracia no mundo de hoje, cit., p. 315.

${ }^{190}$ CALAMANDREI, Piero, Il processo come giuoco, cit., p. 23.
} 


\begin{abstract}
$\grave{E}$ vero che le leggi processuali sono dettate nell'interesse pubblico della giustizia: lo scopo supremo che lo Stato idealmente pone come meta ad ogni litigante, $e$ in generale a tutte le persone che in una veste $o$ in un'altra partecipano al processo o vi collaborano, è l'osservanza del diritto, il trionfo della verità, la vittoria della ragione. Ma in concreto, se si può sperare che nella massima parte dei casi questo scopo sia effetivamente raggiunto, ciò avviene non perché tutti $i$ personaggi che prendono parte al processo lo vogliano raggiungere nello stesso modo: in realtà, se si esclude il giudice, nel quale dovrebbe concretamente personificarsi questo superiore interesse della giustizia che è proprio dello Stato, tutti gli altri soggetti perseguono nel processo scopi più limitati e più grettamente egoistici, talvolta in contrasto (se pur non confessato) con quello scopo superiore. Dipende dalla somma algebrica di questi sforzi contrastanti (delle azioni e delle omissioni, delle astuzie o delle sviste, delle mosse indovinate e di quelle sbagliate) se alla fine il processo, come sintesi, riesce a raggiungere un resultato che veramente corrisponda alla giustizia; ma per le due parti in contrasto (tesi e antitesi) spesso accade che quel che conta non è tanto la giustizia quanto la vittoria: sicché, per esse, il processo diventa nient'altro che un giuoco per vincere.
\end{abstract}

Barbosa Moreira, em instigante ensaio, investigou o chamando "duelo judiciário" e suas raízes medievais, analisando o advogado forense norte-americano e seu treinamento destinado aos "embates do trial". Seria esse o momento por excelência do exercício da combatividade e da astúcia ${ }^{191}$, valores também apontados há décadas por Calamandrei.

De fato, houve um tempo em que as guerras eram consideradas um jogo entre cavalheiros e os padrões de conduta dos jogos prevaleciam na maneira de conduzir as agressões. Certas posições eram consideradas indefensáveis e quando os exércitos se encontravam em tais posições, rendiam-se. Se nenhum dos dois lados conseguia obter uma vantagem, iniciavam-se negociações, que às vezes terminavam em aceitação do statu quo por ambos os lados. ${ }^{192}$

A economia tem tentado estabelecer fórmulas de análise dos fenômenos jurídicos, por meio de diversas ferramentas, tais como a jurimetria ${ }^{193}$ e a teoria dos jogos. ${ }^{194}$

Especificamente quanto à teoria dos jogos, vem ela ganhando importância crescente na formulação de raciocínios econômicos e jurídicos, especificando maneiras de se lidar com a cooperação e o conflito, e estudando as decisões tomadas em situações nas quais os jogadores (ou litigantes) interagem. Para tanto, a teoria estuda a escolha de estratégias

${ }^{191}$ MOREIRA, José Carlos Barbosa, Duelo e processo, cit., p. 115-125.

192 RAPOPORT, Anatol. Lutas, jogos e debates. Tradução de Sergio Duarte. Brasília: Editora da Universidade de Brasília, 1980. p. 117.

${ }^{193}$ POSNER, Richard A. A economia da justiça. São Paulo: Martins Fontes, 2010.

${ }^{194}$ PICKER, Randall C. An introduction to game theory and the law. Chicago: University of Chicago Law School, 1994. (Coase-Sandor Institute for Law \& Economics Working Paper, n. 22). 
quando os custos e os benefícios de cada opção dependem de escolhas feitas pelos adversários, e pressupõe a aplicação de regras lógicas ao processo de tomada de decisões.

A teoria usa os seguintes elementos básicos principais: jogos, jogadores, jogadas, estratégias e resultados. O jogo é a situação na qual há dois ou mais jogadores, em que as decisões de um podem interferir nas decisões dos demais. Jogador é o participante, cujo proposito é obter determinado resultado. Jogada é a forma como o jogo progride, por meio de estágios. Resultado é a vitória, o empate ou a derrota, obtida ao final do jogo. Estratégias são as ações que o jogador pode adotar nos momentos em que deve jogar, dependendo dos conjuntos de informação que estiverem disponíveis naquele estágio. ${ }^{195}$

A moderna teoria dos jogos teve início com os trabalhos dos matemáticos Zemello, Borel e von Neumann, nas décadas de 1910 e 1920, consolidando-se efetivamente a partir da obra fundamental de John von Neumann e Oskar Morgenstern denominada The theory of games and economic behavior, de 1994, e das pesquisas de Nohn Nash, nos anos 50. Um primeiro impulso ao seu desenvolvimento foram as pesquisas estimuladas pela Segunda Guerra Mundial e pela Guerra Fria, nas áreas militares e de estratégia. Progressivamente, deu-se o desenvolvimento da teoria em outras áreas, inclusive, o direito. ${ }^{196}$

Em um mundo onde praticamente todos os aspectos da vida humana são progressivamente globalizados, parece natural que as oportunidades de litígios internacionais também se internacionalizem. Esse fenômeno tem sido notado a partir da segunda metade do século XX, quando os demandantes privados iniciaram uma progressiva utilização de cortes localizadas além de sua própria jurisdição, objetivando com isso alguma vantagem ${ }^{197}$. Essa vantagem desdobra-se em três análises principais: duração do processo, aspectos jurídicos propriamente ditos (direito material) e custo, decorrente não só dos honorários profissionais que se demandarão na jurisdição escolhida, como também das custas judiciais e despesas. A combinação desses fatores (ditos

\footnotetext{
${ }^{195}$ RADINSKY, Marla. Retaliation: the genesis of a law and the evolution toward international cooperation: an application of game theory to modern international conflicts. George Mason University Law Review, v. 2, n. 53, p. 54-75, Fall 1994; COOTER, Robert; ULEN, Thomas. Law and economics. Boston: Pearson Addison Wesley, 2007.

${ }^{196}$ MYERSON, Roger B. Game theory: analysis of conflict. Cambridge, Mass.: Harvard University Press, 1997. p. 2.

${ }^{197}$ GUTHRIE, Neil. "A good place to shop": choice of forum and the conflict of laws. Otawa Law Review, v. 27, p. 203-231, 1995.
} 
"variáveis") pode significar uma maior vantagem competitiva em favor de um dos litigantes, que por seu turno significará melhor resultado.

Exemplificativamente, serão trazidos a seguir os dados do último relatório divulgado em 2014 pela Comissão Europeia para a Eficiência da Justiça (CEPEJ), referente ao ano de 2012, no qual se consolidou uma série de informações sobre a administração judiciária de seus membros. ${ }^{198}$

a) Duração dos processos em diversas jurisdições

Generalizou-se nas últimas décadas o entendimento de que o direito ao acesso à Justiça compreende, além do abrigo da ordem jurídica justa, a resolução dos conflitos num tempo razoável ${ }^{199}$, tudo dentro do arcabouço da força expansiva dos direitos humanos, o que levou o Conselho da Europa, por intermédio da CEPEJ, a mapear a duração dos litígios que tramitam no seu âmbito, buscando melhorar a eficiência e o funcionamento da Justiça.

Segundo o relatório, os países com menor índice de resolução de demandas cíveis e comerciais em 2012 foram Andorra, Bósnia e Herzegovina, Croácia, Portugal e Eslováquia. Com um alerta sobre uma possível piora no futuro, caso não sejam tomadas medidas específicas, estão a Grécia e a Polônia, no caso dos processos litigiosos, e a Bósnia e Herzegovina, para os casos não litigiosos. ${ }^{200}$

\footnotetext{
198 Esses dados foram obtidos da Albânia, Andorra, Armênia, Áustria, Azerbaijão, Bélgica, Bósnia e Herzegovina, Bulgária, Croácia, Chipre, República Checa, Dinamarca, Estônia, Finlândia, França, Geórgia, Alemanha, Grécia, Hungria, Islândia, Irlanda do Sul, Itália, Letônia, Lituânia, Luxemburgo, Malta, Moldávia, Mônaco, Montenegro, Holanda, Noruega, Polônia, Portugal, Romênia, Rússia, Sérvia, Eslováquia, Eslovênia, Espanha, Suécia, Suíça, Macedônia, Turquia, Ucrânia e Reino Unido. Apenas Liechtenstein e São Marino não enviaram as informações ao órgão (EUROPEAN COMMISSION FOR THE EFFICIENCY OF JUSTICE (CEPEJ). Report on "European judicial systems - Edition 2014 (2012 data): efficiency and quality of justice”. p. 8. Disponível em: <http://www.coe.int/t/dghl/cooperation/cepej/evaluation/2014/Rapport_2014_en.pdf>. Acesso em: 15 maio 2015).

${ }^{199} \mathrm{Na}$ França, Jehanne Collard denunciou o sistema processual francês da década de 90. Escreveu ele: "Pode parecer espantoso, mas são problemas com a máquina de escrever que bloqueiam a Justiça francesa. No Tribunal de Bordeaux, fevereiro de 1996, 1.126 julgamentos estavam à espera de datilografia, a despeito da contratação de 10 novos funcionários. A asfixia do sistema é tamanha que mesmo os procedimentos de urgência estão saturados e perdem todo o seu sentido." (Victimes: les oubliés de la justice, apud TUCCI, José Rogério Cruz, Tempo e processo: uma análise empírica das repercussões do tempo na fenomenologia processual (civil e penal), cit., p. 93).

${ }^{200}$ EUROPEAN COMMISSION FOR THE EFFICIENCY OF JUSTICE (CEPEJ), Report on "European judicial systems - Edition 2014 (2012 data): efficiency and quality of justice”, cit., p. 264.
} 
No Brasil, o Conselho Nacional de Justiça (CNJ) disponibiliza uma série de informações sobre o volume de processos, produtividade de tribunais e tempo médio de duração das demandas. ${ }^{201}$

Deve-se somar a esse prazo o eventual interregno necessário à homologação em outro foro da sentença obtida no exterior que, no Brasil, é de competência do STJ, desde a Emenda Constitucional n. 45/2004.

b) Custas judicias, taxas e honorários de sucumbência

Na maioria dos Estados membros da União Europeia, a isenção de custas judiciais é destinada a casos específicos, tais como a alguns procedimentos cíveis (Albânia), a procedimentos relacionados à defesa de direitos e valores constitucionais (Portugal), direito administrativo (Bulgária, Estônia), direito do trabalho ou previdenciário (Azerbaijão, Bósnia e Herzegovina, Bulgária, Croácia, Estônia, Itália, Lituânia, Moldávia, Polônia, Romênia, Eslováquia, Eslovênia, Suíça), direito de família ou de menores (Finlândia, Irlanda, Itália, Lituânia, Moldávia, Noruega, Espanha, Polônia, Portugal, Romênia), estado civil (Espanha), agricultura (Itália), impostos (Portugal), eleitoral (Romênia) ou locação de residências (Suíça). Alguns Estados exigem que as custas judiciais devam ser pagas apenas no final do processo (Finlândia). ${ }^{202}$

Os custos de um processo judicial não consistem apenas em despesas de representação em juízo, assessoria jurídica, custas e emolumentos, mas também podem incluir os honorários de sucumbência. As custas judiciais devem geralmente ser reembolsadas pela parte vencida, ou quando o tribunal criminal decide que a parte não é culpada. Apenas dois Estados não cobram custas judiciais (França e Luxemburgo). Em matéria criminal, existe a cobrança de custas para os casos em que não foi deferida a justiça gratuita (Croácia, Chipre, Grécia, Mônaco, Montenegro, Portugal, Sérvia e Suíça). ${ }^{203}$

\footnotetext{
201 A última informação disponível é de 2014, referente ao ano base de 2013. Disponível em: <http://www.cnj.jus.br/images/programas/justica-em-numeros/Resumo_Justica_em_Numeros_2014_anobase_2013.pdf >. Acesso em: 15 maio 2015.

${ }^{202}$ EUROPEAN COMMISSION FOR THE EFFICIENCY OF JUSTICE (CEPEJ), Report on "European judicial systems - Edition 2014 (2012 data): efficiency and quality of justice", cit., p. 75.

${ }^{203}$ Ibidem, p. 83.
} 
c) Direito material mais favorável

De um modo geral, a doutrina internacional tem analisado o forum shopping muito mais pelo direito a ser aplicado no caso concreto, à vista de uma jurisdição cuidadosamente pinçada pelo shopper.

A escolha da jurisdição pode estar relacionada à forma com que aquele sistema jurídico resolve, em tese, o caso concreto que terá, muito provavelmente, elementos estrangeiros. Como ensina Ferrer Correia, enquanto não chega à era de uma codificação geral de direito internacional privado, por meio de convenções entre os Estados, cada legislador nacional pode suprir por sua própria iniciativa, dentro da esfera em que é soberano, essa falta de regras de conflito universalmente válidas. ${ }^{204}$

Ferrer Correia aponta como consequência da legislação não uniforme sobre os conflitos de leis, a partir do século XIX, o fato de que em muitas legislações o chamado “estatuto pessoal" foi regulado pela lex patriae, enquanto noutras foi regido pela lex domicilii e, em algumas, pela lei da residência habitual. São também muitas as divergências existentes quanto à esfera de competência da lex rei sitae. Existem países que reconhecem tal princípio na regulamentação das sucessões por morte (quanto à herança constituída por bens imóveis), muito embora em outros países essa matéria seja tratada no âmbito do estatuto pessoal. Mesmo quanto às formalidades dos atos e negócios jurídicos, se em todas as partes se admite a competência da lex loci, prevalece hoje em dia a doutrina da regra locus regit actum. Além disso, relativamente às condições de validade intrínseca dos negócios jurídicos e aos respectivos efeitos, existem muitas divergências sobre os critérios. $^{205}$

De uma forma geral, a relação jurídica controvertida passível de ser apreciada em diferentes jurisdições pode ter resultados absolutamente díspares, pela aplicação não só da lei material do foro, como pela lei estrangeira, no caso de emprego das regras locais de direito internacional privado.

\footnotetext{
${ }^{204}$ CORREIA, Antonio de Arruda Ferrer. Lições de direito internacional privado. Lisboa: Almedina, 2010. v. 1, p. 129.

205 Ibidem, v. 1, p. 130.
} 
Esse resultado diferenciado ainda sofre modulações, em virtude de ocorrências endoprocessuais, tais como a litispendência internacional, prevista no âmbito da União Europeia e do Mercosul, respectivamente pelo Regulamento (CE) 1.215/2012 e do Protocolo de Las Leñas, na segunda parte do artigo 22.

\section{d) Teoria dos jogos e forum shopping}

Não é o escopo do presente trabalho discorrer sobre os fundamentos da teoria dos jogos, porém, fazem-se necessárias algumas conceituações de ordem econômica. Segundo Neumann e Morgenstern, jogo é qualquer interação entre agentes, governada por um conjunto de regras que especificam os possíveis movimentos de cada participante e por um conjunto de resultados para cada combinação possível de movimentos. ${ }^{206}$

Estratégia pode ser definida como a arte de aplicar com eficácia os recursos de que se dispõe ou de explorar as condições favoráveis de que porventura se desfrute, visando ao alcance de determinados objetivos. ${ }^{207}$

Os modelos matemáticos são construídos segundo a concepção de que os jogadores são racionais e buscam maximizar os resultados, em seu próprio interesse ${ }^{208}$. As escolhas dos jogadores se baseiam em estratégias, porém serão influenciadas pelas jogadas do adversário. A teoria dos jogos busca justamente estudar as possíveis intenções dos jogadores, baseada no fato de que ambos são racionais e buscam o melhor resultado para si, determinando quais serão as mais prováveis jogadas de cada um. ${ }^{209}$

\footnotetext{
206 NEUMANN, John; MORGENSTER, Oskar. Theory of games and economic behaviour. Princeton, NJ: Princeton University Press, 2007. p. 3.

207 O Dicionário Houaiss, também inclui os seguintes outros significados: "arte de coordenar a ação das forças militares, políticas, econômicas e morais implicadas na condução de um conflito ou na preparação da defesa de uma nação ou comunidade de nações" e "parte da arte militar que trata das operações e movimentos de um exército, até chegar, em condições vantajosas, à presença do inimigo" ou ainda "arte de aplicar com eficácia os recursos de que se dispõe ou de explorar as condições favoráveis de que porventura se desfrute, visando ao alcance de determinados objetivos". (HOUAISS, Antônio. Dicionário Houaiss da língua portuguesa. Rio de Janeiro: Objetiva, 2009).

${ }^{208}$ POSNER, Richard A., A economia da justiça, cit., p. 4.

${ }^{209}$ A teoria dos jogos é eficiente ao analisar as interações de dois ou mais jogadores, em que cada um deles possua duas ou mais alternativas de ação (ADLER, Barry E. A re-examination of near-bankruptcy investiment incentives. University of Chigago Law Review, v. 62, No. 2, p. 580, Spring, 1995).
} 
Jogos de xadrez usam suas peças em sequências de movimento; estratégias militares utilizam tropas, armas e propaganda de guerra. Em cada modalidade de disputa, a primeira função do estrategista é compreender os jogadores, reunir as informações disponíveis e combinar as variáveis que podem incidir no desafio. Segundo Lopucki e Weirauch, estratégias jurídicas trabalham com tomadores de decisões, fatos, culturas jurídicas e normas. Tomadores de decisões são os juízes, os júris, árbitros, administradores, advogados e as próprias partes. Os fatos são os eventos, tanto os passados quanto os futuros, que vão compor as provas e influenciar as decisões judiciais. Culturas jurídicas são os conjuntos de práticas, percepções e expectativas que cada foro ou jurisdição possui. Por fim, normas são as regras de direito material e processual que serão aplicadas pelo foro. ${ }^{210}$

No litígio judicial, as partes executam sua estratégia num ambiente em que as regras são o mais das vezes complexas, no sentido de que sua compreensão nem sempre é a mesma para todos os jogadores. Isto é, a não ser nas hipóteses de abuso do direito, em que as partes concordam sobre o resultado do mérito do litígio, é possível que os jogadores, na maioria das vezes, tenham um entendimento divergente sobre as próprias regras que incidem no jogo. ${ }^{211}$

Num potencial litígio internacional, a primeira hipótese que as partes deverão analisar é se tomarão a iniciativa do contencioso, isto é, se cada uma aguardará (como réu) a iniciativa da outra parte, ou se irão tomar a iniciativa do contencioso. Essa decisão é importante e levará em conta as jurisdições passíveis de serem escolhidas (forum shopping). Nesse aspecto, diversas jurisdições consideram a primeira demanda proposta como o centro de gravidade de todas as demandas conexas futuras (como é o caso do Regime de Bruxelas-Lugano). Do mesmo modo, em sendo o caso de se tomar a iniciativa do contencioso, é possível que, ao invés da demanda condenatória, a parte decida por um forum shopping reverso, na modalidade de uma ação declaratória (como é o caso do torpedo, que será comentado com mais vagar oportunamente). Por outro lado, é possível

\footnotetext{
${ }^{210}$ LOPUCKI, Lynn M.; WEIRAUCH, Walter O. A theory of legal strategy. Duke Law Journal, v. 49, p. $1.429,2000$.

${ }^{211}$ GILSON, Ronald J.; MNOOKIN, Robert H. Disputing through agents: cooperation and conflict between lawyers in litigation. Columbia Law Review, v. 94, p. 509, 1994.
} 
que a parte se decida por não iniciar o litígio e aguardar a iniciativa da outra parte, visando com isso a estabelecer uma linha defensiva. ${ }^{212}$

Essa escolha deve levar em conta o custo do litigio em cada uma das jurisdições analisadas, o lapso que decorrerá em cada uma das hipóteses (se a parte tomará a iniciativa do contencioso ou se aguardará o movimento inicial da outra parte) e o direito que será potencialmente aplicado em cada jurisdição pelo juiz do foro. ${ }^{213}$

${ }^{212}$ LOWENFELD, Andreas. Forum shopping, antisuit injunctions, negative declarations, and related tools of international litigation. Editorial comment. American Journal of International Law, v. 91, No. 2, p. 320, 1997.

213 VON MEHREN, Arthur T. Theory and practice of adjudicatory authority. Recueil des Cours de l'Académie de Droit International de La Haye, v. 295, p. 395, 2002. 


\section{CAPÍTULO 2 - FUNDAMENTOS DO FORUM SHOPPING NO COMMON LAW}

Segundo Friedrich Junger, o termo forum shopping foi utilizado em juízo pela primeira vez nos Estados Unidos, em 1952. Porém, ele alerta que a expressão já teria sido usada em aulas de direito internacional americanas em 1927, ou até mesmo antes ${ }^{214}$. Desde então, a prática do forum shopping passou a ser considerada pelo juiz Skelly Wright "o passatempo jurídico nacional" dos americanos. ${ }^{215}$

Em 1945, no caso International Shoe v. Washington, a Suprema Corte dos Estados Unidos - dentre outros fundamentos - considerou o forum shopping como parte do devido processo legal, pela expansão da competência dos Estados por meio dos long-arm statutes $^{216}$, que por sua vez permitem que um ou mais Estados americanos detenham competência para julgar o réu que, por sua vez, tenha algum "contato mínimo" com o foro. Essa competência alargada, no dizer da corte distrital da Virgínia, autorizou alguns graus legítimos de forum shopping no sistema norte americano. ${ }^{217}$

A partir desse leading case, multiplicaram-se as opções a serem consideradas pelos demandantes nas ações movidas contra grandes empresas, na medida que tais corporações têm contato com numerosos Estados. ${ }^{218}$

O estudo cuidadoso dos requisitos previstos nos long-arm statutes e o teste de “mínimo contato" permitiu um sem-número de novas estratégias processuais, objetivando encontrar a melhor jurisdição para o caso. Um estudo de 1995 na Suprema Corte americana mostrou que em todos os casos em que a competência impugnada pelo réu fora mantida, desde o caso International Shoe, o autor venceu o processo no mérito. ${ }^{219}$

\footnotetext{
${ }^{214}$ JUENGER, Friedrich K. Forum shopping, domestic and international. Tulane Law Review, v. 63, p. 553, 1988-1989.

${ }^{215}$ WRIGHT, Skelly. The federal courts and the nature and quality of state law. Wayne Law Review, v. 13, p. 317-333, 1967.

216326 US 310 (1945); JUENGER, Friedrich K., op. cit., p. 554; SIMOWITZ, Aaron, A U.S. perspective on forum shopping, ethical obligations, and international commercial arbitration, cit., p. 24.

${ }^{217}$ SIMOWITZ, Aaron, op. cit., p. 27.

${ }^{218}$ JUENGER, Friedrich K., op. cit., p. 557.

${ }^{219}$ CAMERON, Christopher D.; JOHNSON, Kevin R. Death of a salesman? Forum shopping and outcome determination under international shoe. UC Davis Law Review, v. 28, p. 779, 1994-1995.
} 
Além disso, Juenger aponta outras hipóteses em que o demandante já podia escolher o foro da demanda antes do caso International Shoe. Desde 1878, pelo precedente Pennoyer $v$. Neff, os demandantes norte-americanos têm a possibilidade de propor sua demanda no local em que o réu possua alguma propriedade (quase in rem jurisdiction). Nos casos em que o réu tenha por hábito "perambular", pode ele ser citado e processado onde quer que venha ser a encontrado, conforme o precedente Smith v. Gibson, de 1888. Finalmente, pelo precedente Harris $v$. Balk, de 1905, foi estendida a hipótese da quase in rem jurisdiction para onde se encontrarem ativos intangíveis do demandado. ${ }^{220}$

Como já mencionado anteriormente, as hipóteses de competência firmada no local da citação do réu onde ele seja encontrado ou onde ele possua propriedades confere um amplo espectro de possibilidades aos demandantes de criar embaraços aos demandados, sendo apontadas muitas vezes como exemplo de jurisdições exorbitantes.

A expertise dos advogados americanos na prática do forum shopping passou a beneficiar demandantes estrangeiros, principalmente nos casos de ações de responsabilidade civil, visando ao recebimento de generosas indenizações.

Juergen lembra do acidente aéreo com a aeronave DC-10 operada pela Turkish Airline, que fazia a rota Paris-Londres, em 1980. O avião caiu na França, próximo à floresta de Ermenonville, matando 330 passageiros de 5 continentes, além de 13 membros da tripulação. A viúva de uma vítima inglesa propôs uma ação indenizatória numa corte federal de Los Angeles quinze dias após o acidente; peritos americanos propagaram aos quatro cantos as vantagens das cortes americanas, fazendo com que diversos familiares propusessem as ações nos Estados Unidos. Com o propósito de evitar as restrições indenizatórias à época previstas na Convenção de Varsóvia, que limitavam os prejuízos a serem indenizados pelas companhias aéreas, foram propostas ações contra os fabricantes das partes e peças da aeronave. Espalhadas pelos mais diversos Estados americanos, ações judiciais movidas por mais de mil e cem autores foram reunidas num procedimento comum, em Los Angeles. Após a primeira condenação no valor de US\$ 1,5 milhões e US\$

${ }^{220}$ JUENGER, Friedrich K., Forum shopping, domestic and international, cit., p. 555. 
1 milhão, respectivamente, em favor de dois órfãos por um júri civil, iniciou-se o procedimento de negociação das demandas pendentes. ${ }^{221}$

Esse caso demonstra a razão pela qual Lord Denning, Master of the Rolls do Reino Unido, ter afirmado que "assim como a mariposa é atraída para a luz, os litigantes são atraídos aos Estados Unidos". 222

A partir de então, fortaleceu-se a discussão no âmbito mundial a respeito do forum shopping e seus possíveis efeitos nefastos, abrindo-se a discussão nos diversos sistemas sobre sua forma de mitigação, desde a aplicação da doutrina do forum non conveniens nos países do common law, como a tentativa de se regular a competência internacional por tratados.

\subsection{Conceito}

Em 1972, Lord Denning, no julgamento do leading case The Atlantic Star pela Corte de Apelações da Inglaterra e País de Gales, não viu razão para limitar o acesso às cortes inglesas apenas aos seus próprios nacionais, entendendo não haver objeção para que "estrangeiros amistosos" utilizassem as cortes por intermédio do forum shopping:

This right to come here is not confined to Englishmen. It extends to any friendly foreigner. He can seek the aid of our courts if he desires to do so. You may call this 'forum shopping' if you please, but if the forum is England, it is a good place to shop in, both for the quality of the goods and the speed of service. ${ }^{223}$

Essa posição foi reforçada por Lord Simon of Glaisdale naquele mesmo julgamento, muito embora esse juiz considerasse forum shopping uma expressão chula. Mesmo assim, tal prática não mereceria nem surpresa, tampouco indignação.

"Forum-shopping" is a dirty word; but it is only a pejorative way of saying that, if you offer a plaintiff a choice of jurisdictions, he will naturally choose the one in which he thinks his case can be most favourably presented: this should be a matter neither for surprise nor for indignation.

${ }^{221}$ JUENGER, Friedrich K., Forum shopping, domestic and international, cit., p. 562.

${ }^{222}$ Smith Kline \& French Laboratories, Ltd. v. Bloch, [1983] 2 All E.R. 72, 74 (C.A.)

${ }^{223}$ Atlantic Star v. Bona Spes, [1974] A.C. 436, 471 (opinion of Lord Denning). 
De um modo geral, o termo forum shopping tem sido utilizado pela doutrina internacional pejorativamente ${ }^{224}$, indicando uma opção o mais das vezes "maléfica"225 e, portanto, a ser evitada. ${ }^{226}$

Essa condenação ao forum shopping atingiu um nível verdadeiramente continental, conforme pode ser visto no âmbito da União Europeia, em diversos estudos ali produzidos. Mario Giuliano e Paul Lagarde, responsáveis pelo relatório sobre a convenção europeia sobre a lei aplicável às obrigações contratuais ("Roma I”), em 1980, consignaram que:

Para prevenir este forum shopping, reforçar a segurança jurídica e prever mais facilmente o direito que será aplicado, seria desejável que as regras de conflito fossem unificadas nos domínios de importância económica particular, de modo a que o mesmo direito possa ser aplicado seja qual for o Estado em que for pronunciada a decisão. ${ }^{227}$

Fausto $\operatorname{Pocar}^{228}$, em relatório explicativo da convenção relativa à competência judiciária, ao reconhecimento e à execução de decisões em matéria civil e comercial, assinada em Lugano, em 30 de outubro de 2007, apontou diversas passagens da dita convenção em que o forum shopping seria possível, não obstante a sistematização da matéria. Do mesmo modo, no $4^{\circ}$ considerando do Regulamento (CE) 1.346/2000 do Conselho, relativo aos processos de insolvência, fez-se constar que "para assegurar o bom funcionamento do mercado interno, há que evitar quaisquer incentivos que levem as partes

${ }^{224}$ JUENGER, Friedrich K., Forum shopping, domestic and international, cit., p. 556.

225 STEWART, Charles Evan. The government suspension provision of the Clayton Act's statute of limitations: for whom does it toll? St. John's Law Review, v. 60, p. 70, 1985.

${ }^{226}$ WHITTEN, Ralph U. Improving the "better law" system: some impudent suggestions for reordering and reformulating leflar's choice-influencing considerations. Arkansas Law Review, v. 52, p. 177, 1999.

${ }^{227}$ No original: "To prevent this 'forum shopping', increase legal certainty, and anticipate more easily the law which will be applied, it would be advisable for the rules of conflict to be unified in fields of particular economic importance so that the same law is applied irrespective of the State in which the decision is given." (Report on the Convention on the law applicable to contractual obligations by Mario Giuliano, Professor, University of Milan, and Paul Lagarde, Professor, University of Paris I. Official Journal of the European Communities C 282 31.10.1980, p. 5. Disponível em: <http://eur-lex.europa.eu/legalcontent/EN/TXT/PDF/?uri=OJ:C:1980:282:FULL\&from=PT>. Acesso em: 20 jun. 2015).

${ }^{228}$ Informações oriundas das instituições e dos órgãos da União Europeia: Convenção relativa à competência judiciária, ao reconhecimento e à execução de decisões em matéria civil e comercial assinada em Lugano, em 30 de Outubro de 2007 - Relatório explicativo do Professor Fausto Pocar (Titular da cátedra de Direito Internacional da Universidade de Milão). Jornal Oficial da União Europeia C 319 de 23.12.2009, p. 1-56. Disponível em: <http://eur-lex.europa.eu/legalcontent/PT/TXT/PDF/?uri=OJ:C:2009:319:FULL\&from=PT>. Acesso em: 20 jun. 2015. 
a transferir bens ou acções judiciais de um Estado membro para outro, no intuito de obter uma posição legal mais favorável (forum shopping)". 229

A própria Convenção da Haia sobre aspectos civis do sequestro internacional de crianças, de 1980, no dizer de Gustavo Monaco ${ }^{230}$, filiou-se definitivamente à residência habitual do menor como elemento de conexão para a determinação tanto da competência como da lei aplicável às questões objeto da convenção. Em outras palavras, eliminou o risco de se praticar oforum shopping.

Dentre as mais diversas razões pelas quais se condena o forum shopping na doutrina internacional, há desde o risco de que situações similares poderiam ser resolvidas de maneiras diferentes, o que seria injusto ${ }^{231}$, até fazer com que os litigantes arquem com custos elevados em jurisdições longínquas, ao invés de resolverem suas contendas em cortes mais próximas ${ }^{232}$. Também há inúmeras críticas quanto à possível distorção da

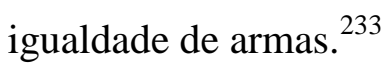

O conceito de forum shopping, de uma forma geral, relaciona-se a uma faculdade de se escolher uma jurisdição para se demandar, em hipóteses em que haja competência internacional concorrente. Franco Ferrari cita a decisão italiana proferida no Tribunal de Rimini, que conceitua forum shopping como a atividade que visa a alcançar a jurisdição mais favorável aos interesses do demandante. ${ }^{234}$

Essa posição citada por Ferrari é comum na doutrina, embora ocorram - em menor número - casos de forum shopping promovidos por parte dos réus ${ }^{235}$. Tais situações ocorrem quando os réus invocam a doutrina do forum non conveniens, quando eles

229 Regulamento (CE) 1.346/2000, de 29.05.2000 (Jornal Oficial das Comunidades Europeias L 160 30.06.2000, p. 1. Disponível em: <http://www.dgpj.mj.pt/sections/relacoes-internacionais/anexos/reg-13462000/downloadFile/file/REG_1346.2000_Insolvencia.pdf?nocache=1200065122.91 >. Acesso em: 20 jun. 2015.

${ }^{230}$ MONACO, Gustavo Ferraz de Campos, A proteção da criança no cenário internacional, cit., p. 274.

${ }^{231}$ KOPPEL, Glenn S. Toward a new federalism in state civil justice: developing a uniform code of state civil procedure through a collaborative rule-making process. Vanderbilt Law Review, v. 58, p. 1.167, 2005.

${ }^{232}$ GOTTESMAN, Michael, H. Draining the dismal swamp: the case for federal choice of law statutes. Georgetown Law Journal, v. 80, p. 13, 1991.

${ }^{233}$ CRUMP, David. The case for restricting diversity jurisdiction: the undeveloped arguments, from the race to the bottom to the substitution effect. Maine Law Review, v. 62, p. 9, 2010.

${ }^{234}$ FERRARI, Franco (Ed.). Forum shopping in the international commercial arbitration context. Munich: Sellier European Law Publishers (SELP), 2013. p. 9.

${ }^{235}$ KOEHNEN, Markus. Reasonable expectations and a principled approach to forum shopping. Advocate's Quarterly, v. 19, p. 311, 1997. 
propõem anti-suit injuction (ambos institutos do common law) e ações declaratórias negativas (rectius: de inexistência de relação jurídica). Tais modalidades de ações defensivas (ou forum shopping reverso) serão tratadas nos tópicos seguintes.

\subsection{Forum shopping e forum non conveniens na tradição do common law}

No common law, a doutrina do forum non conveniens permite ao juiz discricionariamente - negar a apreciação de uma demanda, sob o fundamento de que existe outra jurisdição mais apropriada ao julgamento. ${ }^{236}$

Embora as cortes escocesas sejam consideradas as precursoras dessa doutrina, houve a disseminação e a evolução da teoria em outros países do common law, inclusive como uma das formas de se evitar o forum shopping potencialmente abusivo.

Como será comentado adiante com mais vagar, a disseminação da teoria não significou, todavia, uma aplicação uniforme de seus requisitos e de sua amplitude.

Muito embora a doutrina brasileira faça uma necessária associação entre o forum shopping e o forum non conveniens, como se fossem faces opostas da mesma moeda, há que se ressaltar uma grande diferença entre ambos os conceitos. ${ }^{237}$

Como já mencionado anteriormente, forum shopping é uma faculdade processual decorrente da existência de competências concorrentes entre duas ou mais jurisdições. A faculdade existe, posto que os sistemas de competência internacional dos diversos Estados são diversos, podendo o forum shopping ser ou não abusivo.

Ao invés, o forum non conveniens constitui uma complexa construção teórica, denominada internacionalmente como uma "doutrina", que pode ser aplicada pelo juiz sem que o demandante tenha praticado um forum shopping, mas tão somente pelo simples fato

\footnotetext{
${ }^{236}$ BRAND, Ronald; JABLONSKI, Scotti R. Forum non conveniens: history, global practice, and future under the Hague Convention on Choice of Court Agreements. Oxford: Oxford University Press, 2007. p. 1.

237 Como exemplo dessa associação: JATAHY, Vera Maria Barrera, Do conflito de jurisdições: a competência internacional da justiça brasileira, cit., p. 37; GUERRA, Marcel Vitor de Magalhães; MOSCHEN, Valesca Raizer Borges, Influências do common law no Brasil..., cit., p. 3.710.
} 
de que a prova - exemplificativamente - poderia ser melhor colhida e apreciada no estrangeiro. $^{238}$

Logo, e esse ponto merece ser esclarecido inicialmente, o forum non conveniens serve à própria jurisdição, quando há uma análise prévia de admissibilidade da demanda, ou uma "forum conveniens analysis". 239

Outro ponto relevante é que a invocação da doutrina do forum non conveniens pelo réu constitui, segundo muitos autores, um exercício de forum shopping reverso ${ }^{240}$, assim como a anti-suit injuctions e as ações declaratórias negativas, que serão tratadas oportunamente. O importante a ser considerado é que a o forum non conveniens não é um instituto oposto ao forum shopping (uma faculdade da parte), mas uma doutrina relacionada à própria admissibilidade da demanda (uma discricionariedade da corte). ${ }^{241}$

\subsubsection{Forum shopping como manipulação do local do litígio}

Como já dito em diversas oportunidades, forum shopping decorre de uma situação de competência concorrente entre duas ou mais jurisdições. Se no civil law tem havido um esforço legislativo (inclusive internacional, por meio de convenções) para amenizar a possibilidade de múltiplas competências, no common law o debate é cada vez mais acirrado. $^{242}$

A condenação coletiva ao forum shopping, no âmbito do common law, pode ser sintetizado pelo Master of the Rolls da Corte de Apelação da Inglaterra, Lord Denning:

As a moth is drawn to the light, so is a litigant drawn to the United States. If he can only get his case into their courts, he stands to win a fortune. At no cost to himself, and at no risk of having to pay anything to the other side. The lawyers there will conduct the case 'on spec' as

\footnotetext{
${ }^{238}$ MAZZOLA, Maria. Forum non conveniens and foreign plaintiffs: addressing the unanswered questions of Reyno. Fordham International Law Journal, v. 6, p. 582, 1982.

${ }^{239}$ MARLOWE, Christopher M. Forum non conveniens dismissals and the adequate alternative forum question: Latin America. The University of Miami Inter-American Law Review, v. 32, No. 2, p. 312, Spring/Summer, 2001.

240 BROWN, George D. The ideologies of forum shopping: why doesn't a conservative court protect defendants? North Carolina Law Review, v. 71, No. 1, p. 653, 1993.

${ }^{241}$ LOWENFELD, Andreas, Forum shopping, antisuit injunctions, negative declarations, and related tools of international litigation. Editorial comment, cit., p. 318.

${ }^{242}$ ALGERO, Mary Garvery, In defense of forum shopping: a realistic look at selecting a venue, cit., p. 80; e JUENGER, Friedrich K., Forum shopping, domestic and international, cit., p. 553.
} 
we say, or on a 'contingency fee' as they say. The lawyers will charge the litigant nothing for their services but instead they will take $40 \%$ of the damages, if they win.[...] If they lose, the litigant will have nothing to pay to the other side. The courts in the United States have no such costs deterrent as we have. There is also in the United States a right to trial by jury. These are prone to award fabulous damages. They are notoriously sympathetic and know that the lawyers will take their $40 \%$ before the plaintiff gets anything. All this means that the defendant can be readily forced into a settlement. The plaintiff holds all the cards. ${ }^{243}$

Evidentemente, o juiz inglês não incluiu em sua análise todas as vantagens das cortes americanas sobre as cortes inglesas. Uma das razões mais fortes é o próprio direito material americano que, por exemplo, inclui a possibilidade de recebimento de valores astronômicos a título de punitive damages.

De uma forma geral, a doutrina internacional ataca o forum shopping por pelo menos duas razões principais: a escolha da jurisdição por parte de um dos litigantes pode muitas vezes representar uma injustiça material, e de outro lado, significar uma denegação de justiça. $^{244}$

A injustiça, segundo a jurisprudência e a doutrina no common law, estaria ligada à própria existência do contencioso internacional que, por definição, poderia levar a um resultado diferente, quando comparado com o princípio actor sequitur forum rei. Maloy considera que essa injustiça está ligada ao forum shopping, como uma característica própria implícita ${ }^{245}$. Cortes americanas já decidiram que a ocorrência do forum shopping pode levar a resultados injustos, principalmente pelo fato de que a lei material a ser aplicada será diferente em cada jurisdição potencialmente competente ${ }^{246}$. Do mesmo modo, a aplicação da doutrina do forum non conveniens, principalmente no Reino Unido, tem-se discutido a possível ocorrência de resultados injustos na escolha da jurisdição.

Na primeira decisão em que analisou especificamente o fato de a escolha do foro configurar uma opção injusta ao réu, a Suprema Corte americana, em 1947, dediciu que a opção do demandante não poderia "abusar", "assediar" ou "oprimir" (vex, harass ou oppress) o réu, afligindo-lhe desembolsos ou inconvenientes desnecessários, ao buscar seu direito de acesso à Justiça. Essa decisão foi proferida no famoso leading case Gilbert $v$.

\footnotetext{
${ }^{243}$ Smith Kline \& French Laboratories Ltd $v$. Bloch [1983] 2 All ER 72 at 74 (CA).

${ }^{244}$ PETSCHE, Markus. What's wrong with forum shopping? An attempt to identify and assess the real issues of a controversial practice. International Lawyer, v. 45, p. 1.005, 2011.

${ }^{245}$ MALOY, Richard, Forum shopping? What's wrong with that?, cit., p. 28.

${ }^{246}$ Erie R. R. v. Tompkins, 304 U.S. 64 (1938) (PETSCHE, Markus, op. cit., p. 1.012).
} 
Gulf Oil, embora a jurisprudência atual não mais exija a prova de que o demandante escolheu de fato uma jurisdição "vexatória" ou "opressiva", como foi decidido no caso Piper Aircraft Co. v. Reyno, em $1981^{247}$. Cortes no Reino Unido e Austrália também tem proferido, em certa extensão, decisões similares.

Outro ponto de ataque ao forum shopping pela doutrina e jurisprudência do common law é a perda de eficiência do procedimento jurisdicional, ou seja, a possível denegação de justiça. Levando-se em consideração que o processo deve ser conduzido de forma a evitar dilações indevidas, custos desnecessários e atrasos, parece correto afirmar que certas cortes terão menos condições de apreciar a demanda quando a prova dos fatos não esteja, por exemplo, ligada à jurisdição do litígio. Essa perda de eficiência constitui o mais significativo elemento para aplicação da doutrina do forum non conveniens, por meio de exemplos que se tornaram clássicos no common law, tais como: (a) o indeferimento de uma reclamação trabalhista ajuizada nos Estados Unidos por um marinheiro dinamarquês, em face de um capitão da marinha dinamarquesa por salários atrasados ${ }^{248}$; (b) o indeferimento de uma ação indenizatória proposta em Nova York por um residente da Virgínia, em face de uma empresa da Pensilvânia, por danos sofridos na destruição de um armazém na Virgínia ${ }^{249}$; e (c) a extinção de uma ação indenização por morte proposta na Califórnia ajuizada por demandantes escoceses, em face de réus sediados na Pensilvânia e Ohio, decorrentes de um acidente de avião ocorrido na Escócia. ${ }^{250}$

Outro ponto relacionado à perda de eficiência diz respeito à executividade da sentença estrangeira. Uma das possibilidades de recusa de uma sentença estrangeira na maioria dos sistemas jurídicos é a possível violação à ordem pública, como ocorre nos Estados Unidos ${ }^{251}$, na União Europeia, conforme o artigo 58 do Regime de BruxelasLugano, ou mesmo no Brasil, por meio do artigo 17 da LINDB. A consagração da ordem pública é generalizada no contexto internacional ${ }^{252}$, no qual marca presença em larga

\footnotetext{
${ }^{247}$ REUS, Alexander. Judicial discretion: a comparative view of the doctrine of forum non conveniens in the United States, the United Kingdom, and Germany. Loyola of Los Angeles International and Comparative Law Review, v. 16, p. 466, 1994.

${ }^{248}$ Willendson $v$. Forsoket, 29 F. Cas. 1283, 1284 (D. Pa. 1801) (No. 17,682) (PETSCHE, Markus. What's wrong with forum shopping? An attempt to identify and assess the real issues of a controversial practice, cit, p. 1.019).

${ }^{249}$ Gulf Oil Corp. v. Gilbert.

${ }^{250}$ Piper Aircraft Co. $v$. Reyno.

${ }^{251}$ CHAO, Cedric; NEUHOFF, Christine. Enforcement and recognition of foreign judgments in United States courts: a practical perspective. Pepperdine Law Review, v. 29, p. 147, 2001.

${ }^{252}$ STRENGER, Irineu. Direito internacional privado. São Paulo: LTr, 2003. p. 449.
} 
escala, prevendo possível restrição até mesmo aos efeitos dos tratados, quando ofensivos à ordem pública de quaisquer das partes, conforme expressamente previsto no artigo 46, 1, da Convenção de Viena sobre o Direito dos Tratados.

\subsubsection{Forum shopping como legítimo exercício de direito}

Por outro lado, os defensores do forum shopping no âmbito do common law se baseiam na inevitabilidade das competências concorrentes nas diversas jurisdições soberanas do planeta.

Embora na União Europeia o Regime de Bruxelas-Lugano tenha por regra geral que a demanda tenha que ser proposta no Estado membro em que resida o réu, há também uma série de exceções relacionadas à modalidade de litígio, que expressamente favorece o forum shopping. Por outro lado, nos Estados Unidos, há uma série de regras sobrepostas, que levam em conta, por exemplo, os long-arm statutes e o conceito de "poder jurisdicional" (jurisdiction) sobre as partes litigantes. ${ }^{253}$

A Suprema Corte americana tem estabelecido um critério baseado em dois testes para verificar se no caso concreto elas podem apreciar uma demanda movida contra um réu estrangeiro ou não residente nos Estados Unidos.

O primeiro teste é a existência de um mínimo contato (mininum contacts) entre as atividades do réu no Estado em que se situa a corte, estabelecida pela Suprema Corte americana no caso International Shoe Co. v. Washington, em 1946. Assim, a ação poderia ser julgada nos Estados Unidos contra um réu estrangeiro, desde que: (a) esse réu desempenhe algumas atividades no Estado em que a ação tenha sido ajuizada; ou (b) a causa de pedir da demanda tenha relação com alguma atividade que o réu tenha desempenhado naquele Estado, mesmo que tal atividade tenha sido isolada. ${ }^{254}$

\footnotetext{
${ }^{253}$ DUVAL-MAJOR, Jacqueline. One-way ticket home: the federal doctrine of forum non conveniens and the international plaintiff. Cornell Law Review, v. 77, p. 670, 1991.

254326 U.S. 310 (1946). A Suprema Corte decidiu que o tribunal de Washington seria competente para julgar uma demanda envolvendo uma empresa sediada no Delaware, cujo local de maior atividade econômica situava-se em Saint Louis (Missouri), pelo fato de empregar entre 11 e 13 vendedores em Washington, ou seja, pelo fato de ter um "certo contato mínimo" da ré com o território do foro (STEPHAN, Paul B. A becoming modesty: U.S. litigation in the mirror of international law, Depaul Law Review, v. 52, p. 627, 2002).
} 
O segundo teste é a análise de "razoabilidade" (reasonable jurisdiction) na vinculação do réu com a jurisdição americana respectiva. Esse critério de admissibilidade foi estabelecido no caso Word-Wide Volkswagen Corp. v. Moodson ${ }^{255}$, em 1980.

Esses casos ilustram que a Suprema Corte americana reconhece a competência internacional dos tribunais americanos em várias hipóteses. Em primeiro lugar, as cortes americanas geralmente declaram sua competência nos casos propostos contra réus domiciliados ou que tenham atividades (negócios) nos Estados Unidos. Em segundo lugar, nos casos envolvendo réus localizados no exterior, as cortes levam em conta diversos aspectos relacionados à existência de "conexões" com os Estados Unidos.

De uma forma geral, os defensores do forum shopping consideram que os limites estabelecidos pela jurisprudência dos países do common law no reconhecimento de sua competência internacional (e, por exemplo, o Regime de Bruxelas-Lugano no civil law) são por si provas suficientes de que o leque de opções à disposição dos litigantes em geral (e não apenas dos autores) ${ }^{256}$ possui limites que minimizam o abuso.

Em reforço a esse argumento, há também aqueles que consideram que a regra geral, utilizada pela grande maioria dos sistemas legais, quanto ao foro do domicílio do réu actor sequitur form rei-, é um princípio controverso e que, à vista do desenvolvimento do direito internacional, deveria ser revisto, na medida que protege uma das partes em demasia. $^{257}$

\footnotetext{
255444 U.S. 286 (1980). Neste caso, os demandantes - alegando vício de fabricação nos veículos que adquiriram - distribuíram a demanda em Creek Count, em Okahoma, local conhecido pelas altas indenizações concedidas por júri civil. A Suprema Corte, analisando a exceção de incompetência proposta pela ré, considerou não ser razoável que a demanda fosse julgada naquele distrito, considerando ser tanto o demandante quanto o réu residentes em Nova York. Assim, a corte federal de Nova York foi considerada competente para aquela demanda (JUENGER, Friedrich K., Forum shopping, domestic and international, cit., p. 560).

${ }^{256}$ PETSCHE, Markus. What's wrong with forum shopping? An attempt to identify and assess the real issues of a controversial practice, cit., p. 1.030.

${ }^{257}$ VON MEHREN, Arthur Taylor. Must plaintiffs seek out defendants? The contemporary standing of actor sequitur forum rei. The Kings College Law Journal, v. 8, p. 24, 1997-1998. O autor faz uma reflexão sobre o conceito geral de que o foro do réu nem sempre é mais favorável a este, não havendo portanto razão contemporânea para a manutenção desse princípio.
} 
Havendo multiplicidade de opções no plano internacional, outros ainda consideram ser um dever ético do advogado da parte analisar as opções disponíveis, ainda que leve em conta recomendar a propositura de uma demanda em outra jurisdição. ${ }^{258}$

\subsubsection{Teoria sincrética}

Finalmente, no âmbito do common law, desenvolveu-se uma teoria sincrética entre os críticos e os defensores do forum shopping.

Essa teoria leva em conta tanto a inevitabilidade de sua ocorrência, como também a possibilidade de abuso no caso concreto. Dessa forma, o forum shopping é sempre permitido, posto que inevitável, desde que não seja abusivo à outra parte.

O primeiro critério de análise é o reconhecimento do mérito da sentença estrangeira em outras jurisdições, por meio do filtro da ordem pública ${ }^{259}$. Um exemplo clássico dessa teoria é a sentença de punitive damages obtida por demandante europeu em corte americana. Essa sentença não será homologada fora dos Estados Unidos, pois "virtualmente, todos os Estados europeus consideram que as condenações em punitives damages contrariam suas respectivas ordens públicas". 260

Dessa forma, pelo princípio da efetividade, já tratado anteriormente, essa demanda não deveria nem ao mesmo ser conhecida pela corte americana, considerando que a futura sentença não seria homologada pela corte estrangeira, evitando-se dilações indevidas.

O segundo critério avalia a própria jurisdição estrangeira e sua possível exorbitância. O reconhecimento de jurisdições exorbitantes - tema já tratado anteriormente - pode funcionar como um outo filtro impeditivo do reconhecimento de sentenças estrangeiras. $^{261}$

\footnotetext{
${ }^{258}$ CODDINGTON, Clinton H.; HICKS, Randolph S. The arena: defendant's choice of forum. Journal of Air Law and Commerce, v. 46, p. 941, 1981.

${ }^{259}$ CHAO, Cedric; NEUHOFF, Christine, Enforcement and recognition of foreign judgments in United States courts: a practical perspective, cit., p. 147.

${ }^{260}$ KOZIOL, Helmut. Punitive damages: a european perspective. Lousiana Law Review, v. 68, p. 741, 2008.

${ }^{261}$ FERNÁNDEZ ARROYO, Diego P., Aspectos esenciales de la competencia judicial internacional en vistas de su reglamentación interamericana, cit., p. 319.
} 


\subsection{Forum non conveniens no Reino Unido}

Como mencionado anteriormente, forum non conveniens é a doutrina aplicada nos países do common law, pela qual os juízes têm a discricionariedade de indeferir demandas, sob o fundamento de que o litígio terá uma melhor instrução processual se processado em outra jurisdição. $^{262}$

A aplicação dessa doutrina possui características próprias nos Estados do common law que a adotam.

Também é importante mencionar que há uma colisão com os países de tradição do civil law, quanto à ocorrência de litispendência e conexão internacional e seus efeitos, como é o caso dos Estados submetidos ao Regime de Bruxelas-Lugano. Enquanto nesses países a regra prevista no Regulamento (CE) 1.125/2012 define a prevenção dos tribunais do Estado que primeiro conheceu da causa conexa ou litispendente (art. 29), na tradição do common law, o juiz possui a discricionariedade de conhecer ou recusar a causa, independentemente da ocorrência de litispendência ou conexão internacional

Por fim, a análise do forum non conveniens deve levar em conta a possibilidade de a corte considerar-se competente para analisar o caso, e ao mesmo tempo considerar outras jurisdições incompetentes para apreciar demandas conexas ou litispendentes, ou seja, essa doutrina considera a hipótese de a corte deferir medidas inibitórias contra o litigante, para que ele não proponha ou desista de ações propostas em outras jurisdições, sob pena de ser punido com medidas de apoio.

Dessa forma, os tópicos a seguir tratarão das diferenças da doutrina do forum non conveniens em três países do common law (Escócia, Inglaterra e EUA).

\footnotetext{
262 "Forum non conveniens is a doctrine applied in common law judicial systems allowing the court seised of a case the discretion to decline to exercise jurisdiction because the interests of justice are best served if the trial takes place in another court." (BRAND, Ronald A.; JABLONSKI, Scott R. Forum non conveniens: history..., cit., p. 1).
} 


\subsubsection{As origens na Escócia, desde o forum non competens ao "forum mais apropriado"}

Muito embora a Escócia seja parte do Reino Unido, o sistema jurídico escocês desenvolveu-se separadamente da Inglaterra ${ }^{263}$, sendo considerado o precursor da doutrina do forum non conveniens.

Já a partir do início do século XVIII, a jurisprudência escocesa traz casos de indeferimento de demandas quando outras jurisdições se mostravam mais apropriadas para

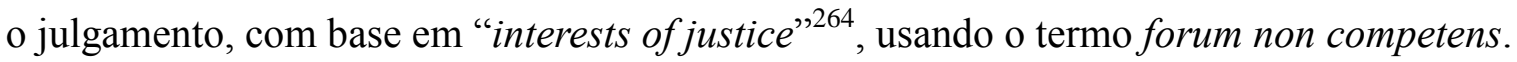

Ao final do século XIX, alterou-se o nome da doutrina para forum non conveniens. Do ponto de vista prático, a mudança deveu-se à transformação da natureza do instituto, que inicialmente era ligada a um pressuposto processual (competência), e depois se transmutou para uma analise de mérito. ${ }^{265}$

Em 1865, no caso Longworth v. Hope ${ }^{266}$, a Scotland's Court of Session (Suprema Corte Civil da Escócia) decidiu num caso de difamação que cabia ao demandante escolher entre a propositura de sua demanda na Inglaterra ou na Escócia, muito embora a primeira opção parecesse mais apropriada, devendo o réu provar que o demandante estaria se aproveitando de uma vantagem injusta do caso.

Em 1892, no caso Sim v. Robinow, a Scotland's Court of Session acrescentou que a demanda não seria indeferida, a não ser que houvesse outra jurisdição concorrente em que o caso poderia ser julgado de forma mais adequada para os interesses de todas as partes e

\footnotetext{
${ }^{263}$ WHITE, Robin M.; WILLOCK, Ian D.; MACQUEEN, Hector L. The scottish legal system. 5th ed. Edinburgh: Bloomsbury Professional, 2013. p. 8.

${ }^{264}$ REUS, Alexander, Judicial discretion: a comparative view of the doctrine of forum non conveniens in the United States, the United Kingdom, and Germany, cit., p. 459.

265 "While this discretionary authority originated as a part of the determination of jurisdiction and went by the name 'forum non competens', by the mi-nineteenth century it had evolved into a separate analysis, considered to be a question on the merits to be addressed after jurisdiction was established." (BRAND, Ronald A.; JABLONSKI, Scott R. Forum non conveniens: history..., cit., p. 8).

2663 M. 1049, 1053 (Sess. Cas. 1865) (Scot.) (BRAUCHER, Robert. The inconvenient federal forum. Harvard Law Review, v. 60, p. 908, 1947).
} 
para os fins da justiça. Como no caso Longworth, caberia ao réu provar que o demandante estava se valendo de uma "vantagem injusta", caso a corte escocesa julgasse o caso. ${ }^{267}$

Em 1926, a House of Lords julgou o recurso oriundo do Scotland's Court of Session, no caso Société du Gaz de Paris v. Société Anonyme de Navigation "Les Armateurs Français" ${ }^{268}$, no qual uma empresa francesa cobrava indenização de um armador francês pela perda da carga durante o trajeto entre a Escócia e a França. A House of Lords manteve a decisão da corte escocesa, que por sua vez aplicou a doutrina do forum non conveniens, considerando ser a jurisdição francesa mais adequada ao julgamento da demanda. O demandante não tinha vínculos (“connection”) com a Escócia, os signatários da petição inicial eram ingleses e a ré era uma empresa francesa. Os danos ocorreram no mar e a maioria das provas documentais estavam escritas em francês. Por conta disso, a corte considerou que o caso seria mais apropriadamente julgado - em favor de ambas as partes - em outra jurisdição, o que significaria ser a justiça melhor concretizada na França do que na Escócia.

Lord Summer, em seu voto favorável à extinção do caso, resumiu que o princípio da doutrina do forum non conveniens não era buscar o foro mais conveniente, mas sim aquele em que a justiça pudesse ser concretizada em sua maior plenitude. A ré não teve que provar que um eventual julgamento na Escócia configuraria um abuso do demandante, ou que essa ação seria opressiva ou vexatória, como exigiam as cortes inglesas da época. ${ }^{269}$

A partir de 1926, com o julgamento do caso La Société du Gaz de Paris, estabeleceu-se a doutrina do forum non conveniens como parte do common law escocesa. $^{270}$

\subsubsection{Forum non conveniens na Inglaterra}

A Inglaterra apenas aderiu à doutrina do forum non conveniens no século XX, sendo que antes disso as cortes inglesas não viam problema em julgar demandas

\footnotetext{
${ }^{267} 1892$ Sess. Cas. 665 (Scot. 1st Div.) (REUS, Alexander, Judicial discretion: a comparative view of the doctrine of forum non conveniens in the United States, the United Kingdom, and Germany, cit., p. 459).

2681926 Sess. Cas. 13 (H.L.) (GROSSI, Simona. The U.S. Supreme Court's modern common law approach. Cambridge: Cambridge University Press, 2015. p. 78).

${ }^{269}$ BRAND, Ronald A.; JABLONSKI, Scott R. Forum non conveniens: history..., cit., p. 10.

${ }^{270}$ REUS, Alexander, op. cit., p. 455.
} 
envolvendo partes internacionais, sendo igualmente lícito julgar estrangeiros do mesmo modo que as cortes do rei julgavam seus súditos. Segundo afirmou Lord Mansfield em 1774 , o estrangeiro teria o mesmo direito de apelar às cortes de sua majestade, como se fosse um típico londrino:

[...] it's impossible there ever could exist a doubt, but that a [foreign] subject born in Moraca [...] has as good a right to appeal to the King's Courts of Justice, as who is born without the sound of Bow Bell. ${ }^{271}$

\subsubsection{O principio "opressivo e vexatório"}

Antes de 1906, o indeferimento das demandas com elementos internacionais ocorria na Inglaterra apenas nas hipóteses de litispendência internacional. Porém, naquele ano, a doutrina foi introduzida no common law inglês, com referências ao direito escocês e a dois precedentes de aplicação do forum non conveniens nos Estados Unidos. Porém, a jurisprudência inglesa utilizou pressupostos próprios no caso Logan v. Bank of Scotland, ou seja, a verificação de situações "vexatórias" e "opressivas" causadas pelo demandante, constituindo um "abuso do processo" por parte do autor ${ }^{272}$. Nesse caso específico, em que o demandante propôs uma ação em face de um banco escocês e de diversos executivos escoceses, a corte considerou "vexatório" exigir que homens de negócios ficassem ocupados, prestando depoimento durante longos períodos, num tribunal estrangeiro (Inglaterra), tendo que levar consigo uma grande gama de documentos, cuja prova poderia ser melhor colhida e examinada na Escócia, onde residiam.

Trinta anos depois, em 1936, o precedente foi confirmado no caso St. Pierre $v$. South American Stores (Goth \& Chaves), Ltd. $^{273}$, no qual a corte inglesa reconheceu que a corte chilena era o foro mais apropriado para julgar aquela demanda: o contrato havia sido escrito em espanhol, o direito eleito pelas partes era o chileno, ambas as partes tinham “conexão" com o Chile, a perícia seria realizada naquele Estado e as testemunhas lá tinham

271 BRAND, Ronald A.; JABLONSKI, Scott R. Forum non conveniens: history..., cit., p. 11. Segundo a tradição inglesa, são considerados "verdadeiramente londrinos" (cockneys, na linguagem popular) apenas e tão somente aqueles que nasceram na região em que se pode ouvir o sino da Igreja de St. Mary-le-bow, ou seja, o "Bow of Bell" (Disponível em:<http://www.stmarylebow.co.uk/\#/bow-bells/4535373284>. Acesso em: 21 jun. 2015).

${ }^{272}$ [1906] 1 K.B. 141 (C.A) (REUS, Alexander, Judicial discretion: a comparative view of the doctrine of forum non conveniens in the United States, the United Kingdom, and Germany, cit., p. 477); CHESHIRE, Geoffrey C.; NORTH, Peter Machin. Private international law. London: Butterworth, 1987. p. 222.

${ }^{273}$ [1936] 1 K.B. 382 (C.A) (BRAND, Ronald A.; JABLONSKI, Scott R. Forum non conveniens: history..., cit., p. 13). 
domicílio. Interessante notar que esse precedente levou em conta que "these grounds only go to convenience", não havendo uma situação vexatória para o réu ou um abuso processual caso a demanda permanecesse na Inglaterra.

\subsubsection{A abordagem do foro mais adequado}

Finalmente, em 1974, deu-se a guinada da jurisprudência inglesa, por meio da decisão proferida pela House of Lords no caso The Atlantic Star. Nesse caso, diminuiu-se a necessidade de o réu produzir provas na invocação da doutrina do forum non conveniens. $^{274}$

Esse é o caso em que Lord Denning se referiu à possibilidade de os litigantes internacionais considerarem as cortes inglesas como "a good place to shop in", já mencionado anteriormente, enquanto seu colega, Lord Simon, considerou o termo forum shopping uma "dirty word".

Tratou-se de uma ação de indenização movida pelos proprietários de uma barcaça, pela ocorrência de uma colisão marítima supostamente causada por um navio cargueiro. $\mathrm{O}$ réu invocou a doutrina do forum non conveniens, alegando não haver conexão alguma entre as partes e a Inglaterra, a não ser pelo fato de o cargueiro utilizar algumas vezes os portos ingleses.

O voto de Lord Reid demonstrou sua relutância em adotar a doutrina escocesa, reconhecendo ser um objetivo desejável reduzir as diferenças remanescentes entre o direito dos dois países, porém ele temia pelas consequências resultantes de mudanças tão profundas no direito inglês: "I cannot foresee all the repercussions of making a fundamental change in English law and I am not all satisfied that is would be proper for this House to make such a fundamental change or that it is necessary or desirable."

\footnotetext{
274 The At. Star, 1974 App. Cas. 436 (appeal taken from C.A.); REUS, Alexander, Judicial discretion: a comparative view of the doctrine of forum non conveniens in the United States, the United Kingdom, and Germany, cit., p. 478; BRAND, Ronald A.; JABLONSKI, Scott R. Forum non conveniens: history..., cit., p. 14; GUTHRIE, Neil, "A good place to shop": choice of forum and the conflict of laws, cit., p. 209; FERRARI, Franco (Ed.), Forum shopping in the international commercial arbitration context, cit., p. 6; JUENGER, Friedrich K., Forum shopping, domestic and international, cit., p. 564; e KOEHNEN, Markus, Reasonable expectations and a principled approach to forum shopping, cit., p. 316.
} 
Mesmo assim, Lord Reid indicou uma posição mais moderna e liberal quanto à aplicação da doutrina, por meio da análise discricionária de cada caso, e levando-se em conta todas as circunstâncias probatórias envolvidas, bem como a situação do réu no caso concreto.

Com esse importante precedente, que mudou a posição da jurisprudência estabelecida no caso St. Pierre, a House of Lords incluiu a doutrina do forum non conveniens quando da análise de mérito dos casos com elementos internacionais ${ }^{275}$, que foi expressamente incorporada ao direito inglês no caso MacShannon v. Rockware Glass Ltd., em 1978.

No caso MacShannon, o autor escocês propôs uma ação indenizatória contra um réu inglês na Inglaterra, sob a alegação (sincera, diga-se) de que a corte escocesa não concederia uma indenização tão vultosa quanto a inglesa, além de a justiça ser mais rápida e eficiente na Inglaterra que na Escócia. A House of Lords aplicou a doutrina do forum non conveniens e indeferiu a demanda, mesmo havendo um réu inglês no polo passivo ${ }^{276}$. Essa decisão tornou mais simples a aplicação da doutrina pelos juízes ingleses.

$\mathrm{O}$ atual entendimento da doutrina do forum non conveniens na Inglaterra foi estabelecido no caso Spiliada Maritime Corp. v. Consulex Ltd. ${ }^{277}$, julgado em 1986 pela House of Lords. Nesse caso, demandantes liberianos propuseram uma ação indenizatória contra réus canadenses, que haviam arrendado o navio para transportar ácido sulfúrico, que por sua vez teria corroído o navio e causado danos aos proprietários.

Os réus tentaram obter o indeferimento do pedido pela invocação da doutrina do forum non conveniens. A corte inglesa declarou, ao invés, ser o caso de um forum conveniens, de modo que os critérios para aferição de ambas as situações seriam os mesmos (identical and inseparable).

\footnotetext{
${ }^{275}$ LOWENFELD, Andreas, Forum shopping, antisuit injunctions, negative declarations, and related tools of international litigation. Editorial comment, cit., p. 314.

${ }^{276}$ [1978] A.C. 795 (H.L) (BRAND, Ronald A.; JABLONSKI, Scott R. Forum non conveniens: history..., cit., p. 15).

277 [1987] A.C. 460 (H.L.) (BRAND, Ronald A.; JABLONSKI, Scott R., op. cit., p. 21).
} 
Os réus apelaram à House of Lords, que por sua vez confirmou a unificação dos requisitos de análise do forum non conveniens e do forum conveniens, cujo resultado deverá ser the most suitable forum, o que unificou o entendimento entre as cortes escocesas e inglesas.

Conforme o entendimento de Lord Goff of Chieveley, a questão era saber qual foro seria o mais apropriado para julgar a demanda, no melhor interesse das partes e visando à plena realização da justiça. Para isso, ele analisou individualmente cada um dos fatores envolvidos: primeiro, a existência de conexão com os possíveis foros, incluindo nessa análise as oportunidades de instrução do feito e o custo envolvido; analisou a lei material aplicável, o domicílio das partes e o local em que realizam negócios e, o mais importante, analisou a possibilidade concreta de o réu obter justiça em outras jurisdições. ${ }^{278}$

Importante notar que a House of Lords não condenou o forum shopping como algo taxativamente condenável, desde que existam conexões suficientes com o foro inglês e seu exercício não seja uma afronta à realização da justiça. ${ }^{279}$

\subsubsection{O sistema Bruxelas-Lugano de definição de competência internacional e seus efeitos no Reino Unido}

Quando o Reino Unido e a Irlanda do Sul se juntaram à Comunidade Econômica Europeia, em 1979, os representantes desses países se empenharam em negociar a introdução da doutrina do forum non conveniens no sistema Bruxelas-Lugano. ${ }^{280}$

O pedido foi recusado pelos outros representantes dos demais Estados partes, sob a alegação de que o Regime de Bruxelas-Lugano já tinha definido as regras de competência

\footnotetext{
${ }^{278}$ GUTHRIE, Neil, "A good place to shop": choice of forum and the conflict of laws, cit., p. 212

${ }^{279}$ REUS, Alexander, Judicial discretion: a comparative view of the doctrine of forum non conveniens in the United States, the United Kingdom, and Germany, cit., p. 479; KOEHNEN, Markus, Reasonable expectations and a principled approach to forum shopping, cit., p. 319; e BRAND, Ronald A.; JABLONSKI, Scott R. Forum non conveniens: history..., cit., p. 21.

${ }^{280}$ Report on the Convention on the Association of the Kingdom of Denmark, Ireland and the United Kingdom of Great Britain and Northern Ireland to the Convention on jurisdiction and the enforcement of judgments in civil and commercial matters and to the Protocol on its interpretation by the Court of Justice, signed at Luxembourg, 9 October 1978 by Professor Dr Peter Schlosser of the Chair of German, international and foreign civil procedure, of the general theory of procedure and of civil law at the University of Munich. Official Journal of the European Communities C 59 05.03.1979, p. 71-151. Disponível em: <http://aei.pitt.edu/1467/1/commercial_reports_schlosser_C_59_79.pdf>. Acesso em: 20 jun. 2015.
} 
internacional em seu âmbito, não havendo espaço para aplicação da discricionariedade judicial. $^{281}$

Dessa forma, o Reino Unido aderiu ao sistema Bruxelas-Lugano em 1987, como parte da Civil Jurisdiction and Judments Act de 1982, inserindo um novo instituto de controle da competência internacional, ao lado do forum non conveniens. ${ }^{282}$

O impacto dessa adesão foi muito profundo no sistema judiciário do Reino Unido pois, em sequência, três decisões do Tribunal de Justiça da União Europeia ${ }^{283}$ abalaram institutos consagrados de processo civil britânicos, a partir de $2003 .^{284}$

Em linhas gerais, o tribunal europeu afastou a aplicação imediata das cláusulas de eleição de foro (casos Gasser ${ }^{285}$ e Turner ${ }^{286}$ ), cassou as anti-suit injuctions (Turner) e impediu a invocação da doutrina do forum non conveniens $\left(\mathrm{Owusu}^{287}\right)$.

O sistema Bruxelas-Lugano continha em seu bojo todas as regras necessárias à definição da competência internacional para julgamento do caso in concreto, o que afastou as regras de defesa do juiz do Reino Unido quanto ao forum shopping abusivo, no dizer de Edwin Peel. ${ }^{288}$

No caso Gasser, a questão envolveu duas partes (Gasser, empresa austríaca, vendedora de roupas infantis, e Misat, empresa romana, distribuidora das ditas roupas em solo italiano). A relação comercial entre as duas empresas era regida por um instrumento de distribuição, com eleição do foro austríaco de Feldkirch para resolução de controvérsias. Em abril de 2000, após tornar-se inadimplente, a empresa italiana Misat propôs uma ação condenatória em face da Gasser, em Roma, alegando culpa da distribuidora pela rescisão do contrato. Em dezembro de 2000, a Gasser propôs uma ação de cobrança contra a Misat

\footnotetext{
${ }^{281}$ Report on the Convention on the Association of the Kingdom [...] by Professor Dr Peter Schlosser, cit.

${ }^{282}$ BRAND, Ronald A.; JABLONSKI, Scott R. Forum non conveniens: history..., cit., p. 24; PEEL, Edwin. Forum shopping in the european judicial area: introductory report. Conference on Forum Shopping in the European Judicial Area. Oxford, UK: University of Oxford, 2006. p. 2. (Oxford Legal Studies Research Paper, No. 39).

${ }^{283}$ Antes do Tratado de Lisboa de 2009, chamava-se Tribunal de Justiça das Comunidades Europeias.

${ }^{284}$ PEEL, Edwin, Forum shopping in the european judicial area: introductory report, cit., p. 2.

${ }^{285}$ Caso C-116/02 Erich Gasser GmbH v MISAT srl [2003] ECR I-0000, [2005] 1 QB 1.

${ }^{286}$ Caso C-159/02 Turner v Grovit [2004] ECR I-0000, [2005] 1 AC 101.

${ }^{287}$ Caso C-281/02 Owusu v Jackson [2005] ECR I-0000, [2005] 2 WLR 942.

${ }^{288}$ PEEL, Edwin, op. cit., p. 4.
} 
em Feldkirch, Áustria. Sendo o caso de conexão entre as duas demandas, o Tribunal de Justiça Europeu, nos termos do artigo 21, parágrafo $1^{\circ}$, da Convenção de Bruxelas, decidiu que o tribunal italiano seria o competente para analisar a questão em primeiro lugar, tendo em vista ser a primeira corte demandada, conforme a regra first served. Com isso, a eleição expressa de foro foi considerada um elemento secundário para fixação da competência internacional da corte. Embora esse caso não tenha relação com partes do Reino Unido, o precedente provocou um forte abalo na tradição britânica quanto à determinação da competência por intermédio da autonomia da vontade. ${ }^{289}$

No caso subsequente, G. Turner, nascido e domiciliado no Reino Unido, foi contratado como assessor jurídico de um grupo de empresas, dirigidas por F. Grovit, em 1990. Em 1997, a pedido do cliente, Turner transferiu-se para Madri. No ano seguinte, Turner demitiu-se e, em março de 1998, propôs em Londres uma reclamação trabalhista contra Grovit. Este, por sua vez, em julho de 1998, propôs uma ação contra Turner em Madri, baseado na existência de uma cláusula de eleição de foro expressa no contrato de trabalho. A pedido de Turner, a Corte de Apelação da Inglaterra e Gales proferiu uma medida liminar (anti-suit injuction), determinando à Grovit que desistisse da ação proposta na Espanha e se abstivesse de propor qualquer outra demanda em face de Turner, sob pena de graves sanções. O tribunal europeu considerou que a decisão proferida pela corte inglesa (anti-suit injuction) era incompatível com a Convenção de Bruxelas, que por sua vez instituiu um regime completo de regras de competência internacional, o que tirou do arbítrio do juiz nacional imiscuir-se em outras jurisdições.

O último caso trata da ação de indenização proposta em outubro de 1997 por A. Owusu, cidadão britânico residente no Reino Unido, por conta de um grave acidente sofrido durante um mergulho num local impróprio (raso), enquanto se encontrava de férias na Jamaica, vindo a ficar tetraplégico. Ao retornar ao Reino Unido, Owusu propôs a ação de indenização em fase de N. B. Jackson, cidadão britânico e também residente no Reino Unido, proprietário do imóvel que havia sido locado a Owusu, bem como contra diversas outras empresas jamaicanas, que em conjunto teriam contribuído para o acidente. $\mathrm{O}$ réu Jackson invocou a doutrina do forum non conveniens, alegando haver partes no processo que não estavam submetidas à Regime de Bruxelas-Lugano (por serem jamaicanas). A

\footnotetext{
${ }^{289}$ PEEL, Edwin, Forum shopping in the european judicial area: introductory report, cit., p. 4.
} 
corte europeia, nos termos do artigo $2^{\circ}$ do Regime de Bruxelas-Lugano, entendeu que a doutrina do forum non conveniens violava o princípio da segurança jurídica e da confiança entre os Estados partes, não sendo possível sua invocação.

Essas três decisões, vindas em sequência e mais de 15 anos após a adesão do Reino Unido ao Regime de Bruxelas-Lugano, constituiu uma verdadeira revolução no sistema de competência internacional britânico, com profundas reflexões na doutrina local que, de uma forma geral, entendeu que os instrumentos processuais podados pela corte europeia eram muito mais eficientes do que as regras continentais. ${ }^{290}$

Quanto às demandas relativas a partes sediadas em outras jurisdições que não as abrigadas sob o Regime de Bruxelas-Lugano, não houve mudanças significativas na aplicação da doutrina do forum non conveniens pelas cortes britânicas. ${ }^{291}$

\subsection{Forum non conveniens nos Estados Unidos}

Nos Estados Unidos, a doutrina do forum non conveniens possui uma longa história, com ocorrências notadas desde o século XVIII, até ser definida pela doutrina em 1929, e reconhecida amplamente pela Suprema Corte em 1947. A doutrina continua em evolução até os dias atuais, com o aprimoramento de suas hipóteses de incidência.

\subsubsection{Digressão histórica}

A doutrina do forum non conveniens nos Estados Unidos, embora não propriamente com essa denominação, pode ser constatada em alguns casos específicos desde o século XVIII. Nesses precedentes, as cortes recusavam o julgamento das demandas que não guardavam relação com o foro, quer pela ausência de domicilio das partes, quer pelo objeto do litígio, por meio de "judicial discretion" 292 . A grande maioria desses processos referiase a assuntos marítimos, em que as partes estrangeiras ingressavam com ações diversas nos

${ }^{290}$ HARTLEY, Trevor C. Anti-suit injunctions and the Brussels Jurisdiction and Judgment Convention. International and Comparative Law Quarterly, v. 44, p. 164, 2000; VON MEHREN, Arthur Taylor, Theory and practice of adjudicatory authority, cit., p. 398; JUENGER, Friedrich K. Some comments on European procedural harmonization. The American Journal of Comparative Law, v. 45, p. 933, 1997.

${ }^{291}$ BRAND, Ronald A.; JABLONSKI, Scott R., Forum non conveniens: history..., cit., p. 33.

${ }^{292}$ REUS, Alexander, Judicial discretion: a comparative view of the doctrine of forum non conveniens in the United States, the United Kingdom, and Germany, cit., p. 460. 
Estados Unidos, pela única razão de o navio ter aportado em solo americano (admiralty roots). ${ }^{293}$

A partir de 1927, alguns Estados aprovaram regras gerais permitindo aos seus juízes um "discretionary power to decline jurisdiction over non-residents", como foi o caso do Maine em 1927, New Hampshire em 1930 e Massachussetts em 1933. ${ }^{294}$

Em 1929, após a percepção de que estavam ocorrendo diversos julgamentos com características similares à doutrina do forum non conveniens, Paxton Blair foi o primeiro jurista americano a dar nome ao instituto. ${ }^{295}$

Em 1932, a Suprema Corte dos Estados Unidos reconheceu a faculdade de as cortes inferiores negarem jurisdição pelo exercício da discricionariedade, não só em questões marítimas ("not be restricted to admiralty cases"), o que consagrou o forum non conveniens nos Estados Unidos ${ }^{296}$. Em 1941, no caso Baltimore \& Ohio R.R. Co. v. Kepner, o juiz da Suprema Corte Justice Felix Frankfurter considerou que a doutrina do forum non conveniens era uma manifestação de um sistema jurídico civilizado, enraizada no direito americano. ${ }^{297}$

\subsubsection{Gilbert and Koster e a doutrina contemporânea}

Em 1947, a consagração final da doutrina do forum non conveniens ocorreu no leading case Gulf Oil Corp. v. Gilbert ${ }^{298}$. Neste caso, um residente da Virgínia propôs sua demanda em uma corte federal de Nova York, em face de uma empresa sediada na Pensilvânia, e que realizava negócios tanto na Virgínia quanto em Nova York. Em linhas gerais, o autor da Virgínia reclamava uma indenização pelo incêndio sofrido em seu depósito, por suposta negligência da empresa-ré. Muito embora a empresa tivesse negócios

${ }^{293}$ BRAND, Ronald A.; JABLONSKI, Scott R., Forum non conveniens: history..., cit., p. 33; e BIES, John. Conditioning forum non conveniens. The University of Chicago Law Review, v. 67, p. 489, 2000.

294 BICKEL, Alexander M. Doctrine of forum non conveniens as applied in the federal courts in matters of admiralty. Cornell Law Quartely, v. 35, p. 14, 1949-1950.

295 BLAIR, Paxton. The doctrine of forum non conveniens in anglo-american law. Columbia Law Review, v. 29, No. 1, p. 21, 1929; Ver, por todos: BRAND, Ronald A.; JABLONSKI, Scott R., Forum non conveniens: history..., cit., p. 37.

296 Canada Malting Co. v. Paterson S.S., 285 U.S. 413 (1932); STEWART, Margareth G.. Forum non conveniens: a doctrine in search of a role. California Law Review, v. 74, p. 1.275, 1986.

${ }^{297}$ Baltimore \& Ohio R.R. Co. v. Kepner, 314, U.S. 44 (1941).

${ }^{298}$ Gulf Oil Corp. v. Gilbert, 330 U.S. 501 (1947). 
no foro (Nova York), a corte entendeu que os eventos que deram origem à demanda ocorreram na Virgínia, extinguindo a ação. $\mathrm{O}$ autor apelou, revertendo o julgamento na instância superior, porém a Suprema Corte reconheceu a discricionariedade da corte em extinguir demandas com base no forum non conveniens.

Muito embora o caso Gilbert envolva exclusivamente elementos americanos (partes, causa de pedir e pedido), ele se tornou o leading case para todas as extinções de processos federais com base na doutrina do forum non conveniens, inclusive casos marítimos, nacionais e internacionais. ${ }^{299}$

A importância do caso Gilbert é que a Suprema Corte abandonou o mero teste de "conveniência" e indicou fatores específicos como elementos de base para as extinções com base na doutrina. A partir desses fatores, as cortes puderam avaliar os prós e contras na prorrogação da competência, levando em conta elementos privados e de direito público, a partir dos quais se determinará o foro mais apropriado para o conhecimento da demanda. Elementos privados incluem: a facilidade de acesso às provas; a existência de procedimentos que obriguem as testemunhas a depor, mesmo que contra sua vontade; o custo necessário à oitiva das testemunhas; a existência de local apropriado para o processo; a eficácia de sentenças que serão executadas no estrangeiro; e qualquer outro problema prático que impeça a realização de um julgamento simples, breve e com um custo razoável. Elementos de direito público incluem: dificuldades administrativas (fóruns congestionados); interesse público no julgamento de demandas no local em que ocorreram os fatos; interesse público no julgamento do caso por uma corte familiarizada com a lei aplicável; dificuldade na aplicação da lei estrangeira; coibição do forum shopping ostensivo; dificuldade criada na comunidade do foro, em que seja exigida participação dos moradores como jurados. ${ }^{300}$

No mesmo dia em que a Suprema Corte julgou o caso Gilbert, julgou também o caso Koster v. Lumbermens Mutual Casualty Co. Nesse último caso, a corte analisou o forum non conveniens a partir da relação entre as partes e o foro. Um investidor nova-

\footnotetext{
${ }^{299}$ JUENGER, Friedrich K., Forum shopping, domestic and international, cit., p. 556.

${ }^{300}$ ROBERTSON, David W. Forum non conveniens in America and England: a rather fantastic fiction. Law Quarterly Review, v. 103, p. 398, 1987; BARRETT, Edward L. The doctrine of forum non conveniens. California Law Review, v. 35, p. 380, 1947; FOSTER, Roger S. Place of trial-interstate application of intrastate methods of adjustment. Harvard Law Review, v. 44, p. 41, 1986.
} 
iorquino propôs uma ação de indenização contra três réus de Illinois, por suposta má gestão da empresa, também sediada em Illinois. Como no caso Gilbert, a Suprema Corte decidiu pela extinção do processo, pela falta de vinculação entre o feito e o foro de Nova York. $^{301}$

Em 1948 (ou seja, um ano após o julgamento dos casos Gilbert e Koster), uma mudança legislativa no trâmite processual no âmbito das cortes federais tornou a aplicação da doutrina do forum non conveniens mais restrita. A mudança é denominada 28 U.S.C. $\S$ 1404(a), e significa o acréscimo de um item (“a”) no parágrafo 1404, que por sua vez está no título 28 ("judiciary and judicial procedure") do Código dos Estados Unidos ("28 U.S.C.”), aplicado às cortes federais americanas. Essa mudança permite à corte remeter os autos para o juízo em que a ação deveria ter sido proposta, "para maior conveniência das partes e testemunhas e no melhor interesse da Justiça" ${ }^{, 302}$. Pela regra do artigo $4^{\circ}$, parágrafo $2^{\circ}$, da Constituição dos Estados Unidos (“full faith and credit clause”), cada Estado é obrigado a reconhecer as decisões proferidas pelos demais, fazendo com que, na prática, as remessas de processos tenham se tornado mais comum do que as extinções oriundas do forum non conveniens. ${ }^{303}$

Em 1964, a Suprema Corte entendeu que a transferência de processos com base na seção 1404(a) obriga a corte destinatária a aplicar a lei material que teria sido aplicada pela corte remetente, no julgamento do caso Van Dusen v. Barrack. Com isso, pretendeu-se evitar um prejuízo maior ao demandante, além de não permitir ao réu que promova um forum shopping baseado na aplicação de uma lei mais benéfica. ${ }^{304}$

Em resumo, com o maior volume de remessas internas dos processos, atualmente, a doutrina do forum non conveniens é aplicada em casos com elementos internacionais. ${ }^{305}$

\footnotetext{
${ }^{301}$ BARRETT, Edward L., The doctrine of forum non conveniens, cit., p. 380.

302 "For the convenience of parties and witnesses, in the interest of justice, a district court may transfer any civil action to any other district or division where it might have been brought." (28 U.S.C. § 1404(a) (1948)) (REUS, Alexander, Judicial discretion: a comparative view of the doctrine of forum non conveniens in the United States, the United Kingdom, and Germany, cit., p. 464).

${ }^{303}$ BRAUCHER, Robert, The inconvenient federal forum, cit., p. 908.

304376 U.S. 612 (1964); GREENBERG, Mark D. The appropriate source of law for forum non conveniens decisions in international cases: a proposal for the development of federal common law. Berkeley Journal of International Law, v. 4, p. 159, 1986.

${ }^{305}$ MANZI, Michael T. Dow Chemical Co. v. Castro Alfaro: the demise of forum non conveniens in Texas and one less barrier to international tort litigation. Fordham International Law Journal, v. 14, p. 822, 1990.
} 


\subsubsection{Piper Aircraft e a atual posição da Suprema Corte}

Em 1981, a Suprema Corte dos Estados Unidos julgou o caso Piper Aircraft Co. $v$. Reyno $^{306}$, atualizando as definições e os parâmetros da doutrina do forum non conveniens.

Nesse caso, os herdeiros e familiares das vítimas de um acidente aéreo ocorrido na Escócia em 1976, propuseram na Califórnia uma ação de indenização por homicídio culposo, em face do construtor da aeronave (uma empresa sediada na Pensilvânia) e do construtor das hélices (uma empresa sediada em Ohio).

Com manifesta sinceridade, os autores alegaram ter escolhido a Califórnia para demandar em face de ambas as companhias, tendo em vista a lei material californiana ser mais favorável aos casos de responsabilidade civil, além de a facilidade de se demandar e o alto valor das indenizações que eram concedidas pelos jurados civis. ${ }^{307}$

Primeiramente, a ação foi transferida da corte estadual da Califórnia para a corte federal e, posteriormente, para a corte estadual da Pensilvânia, ocasião em que os réus apresentaram como matéria de defesa a doutrina do forum non conveniens. A corte aplicou a análise de prós e contras estabelecida no caso Gilbert, e concluiu que a Escócia seria o local mais apropriado para o julgamento da demanda, não obstante o fato de que a lei material não fosse tão favorável aos autores. Como condição para que o processo fosse extinto, os réus concordaram em não alegar a prescrição do direito, bem como se submeterem à futura sentença escocesa. Os autores apelaram e a corte superior cassou a sentença extintiva, pelo fato de que a lei material escocesa era menos vantajosa aos autores.

Finalmente, a Suprema Corte rejeitou o argumento de que a diferença entre leis materiais entre diferentes jurisdições poderia fundamentar a manutenção do processo nos Estados Unidos e afastar a aplicação da doutrina do forum non conveniens.

\footnotetext{
${ }^{306}$ Piper Aircraft Co. v. Reyno, 454 U.S. 235 (1981).

${ }^{307}$ Nas palavras de Justice Marshall: "Reyno candidly admits that the action against Piper and Hartzell was filed in the United States because its laws regarding liability, capacity to sue, and damages are more favorable to her position than are those of Scotland. Scottish law does not recognize strict liability in tort. Moreover, it permits wrongful-death actions only when brought by a decedent's relatives. The relatives may sue only for 'loss of support and society'." (454 U.S. 235, 240 (1981)).
} 
Pela primeira vez, a Suprema Corte americana aplicou o forum non conveniens num caso envolvendo um demandante estrangeiro, salientando não haver um único fator que poderia ser isoladamente determinante para determinação da competência, tal como o domicílio do réu. Também houve uma mudança significativa entre a abordagem do "abuso do direito" na escolha do foro, para o "foro mais adequado" (most suitable forum). ${ }^{308}$

Finalmente, como ponto nevrálgico desse importante precedente, a Suprema Corte estabeleceu critérios para reduzir a atratividade das cortes americanas para demandantes estrangeiros, notadamente para prevenir oforum shopping. ${ }^{309}$

Essa decisão, em linhas gerais, gerou uma proteção maior aos demandantes americanos, protegidos pela regra prevista na 28 U.S.C. 1404(a), que impede a extinção do processo e determina sua transferência ao foro "mais adequado". Porém, quanto aos demandantes estrangeiros, a aplicação do forum non conveniens leva à extinção do processo. $^{310}$

\subsubsection{Cortesia internacional}

Ao mesmo tempo em que se desenvolvia a doutrina do forum non conveniens nos Estados Unidos, as cortes americanas aplicavam a doutrina da international comity como fundamento para extinguir ações que deveriam ser propostas - no entendimento daquelas cortes - em tribunais estrangeiros, embora ambas as teorias relacionam-se com o reconhecimento da competência internacional de fóruns estrangeiros, porém a partir de diferentes fundamentos.

\footnotetext{
308 "Scotland has a very strong interest in this litigation. The accident occurred in its airspace. All of the decedents were Scottish. Apart from Piper and Hartzell, all potential plaintiffs and defendants are either Scottish or English. As we stated in Gilbert, there is 'a local interest in having localized controversies decided at home'. Respondent argues that American citizens have an interest in ensuring that American manufacturers are deterred from producing defective products, and that additional deterrence might be obtained if Piper and Hartzell were tried in the United States, where they could be sued on the basis of both negligence and strict liability. However, the incremental deterrence that would be gained if this trial were held in an [454 U.S. 235, 261] American court is likely to be insignificant. The American interest in this accident is simply not sufficient to justify the enormous commitment of judicial time and resources that would inevitably be required if the case were to be tried here." (454 U.S. 235, 240 (1981)).

309 "Finding that trial in the plaintiff's chosen forum would be burdensome, however, is sufficient to support dismissal on grounds of forum non conveniens." (454 U.S. 235, 240 (1981)).

${ }^{310}$ REUS, Alexander, Judicial discretion: a comparative view of the doctrine of forum non conveniens in the United States, the United Kingdom, and Germany, cit., p. 465.
} 
A origem da doutrina da international comity remonta o século XVII, durante a renascença do Norte da Europa, pelos estudos dos juristas holandeses. O violento movimento de independência da Holanda do império espanhol permitiu a modernização do comércio, a maior tolerância religiosa e a vitória do nacionalismo sobre o paroquialismo e o preconceito. Após trinta anos de guerra, a República holandesa emergiu como um Estado nação, sendo os Tratados de Westphalia de 1648 os primeiros documentos constitutivos do direito internacional moderno, compondo os princípios de soberania estatal, igualdade e respeito às minorais religiosas. ${ }^{311}$

A independência holandesa trouxe muitas discussões sobre a aplicabilidade do direito internacional pelas cortes nacionais, visando não só a unificar o direito aplicável no novo Estado, como também racionalizar o uso do direito espanhol pelas cortes holandesas. Para tanto, durante o século XVII, um grupo de juristas formado por John e Paul Voet, Christian Rodenburg e, principalmente, Ulrich Huber, buscaram construir uma teoria pragmática que resolvesse os conflitos de lei no espaço. Inicialmente, Huber utilizou a expressão comitas gentium (literalmente “civilidade das nações”), para justificar a aplicação das leis estrangeiras. Afirmou Huber que "os altos representantes de cada Estado oferecem as mãos uns aos outros", como se fossem dois comerciantes fechando um negócio. ${ }^{312}$

Essa doutrina foi importada na Inglaterra por Lord Mansfield, quase um século após sua formulação. Advogados (barristers) escoceses, como Mansfield, comungaram dos fundamentos de Huber, o que os distinguiram dos barristers anglicanos ${ }^{313}$. No caso James Sommersett, um escravo nascido nos Estados Unidos (Sommersett) aportou em Londres com seu dono, chamado Stewart, em 1722. Como a Inglaterra tinha considerado a escravidão ilegal, Sommersett, após passar algum tempo em Londres, propôs uma demanda contra seu dono, buscando a declaração judicial de que era um homem livre, e não mais um escravo. Seu dono, Stewart, arguiu na corte inglesa que Sommersett havia nascido escravo sob a regra da lex loci e, portanto, continuava sendo um escravo. O advogado de Sommersett invocou os ensinamentos de Huber, no sentido de que a lex loci

\footnotetext{
${ }^{311}$ GROSS, Leo. The Peace of Westphalia, 1648-1948. American Journal of International Law, v. 42, p. 20, 1948. O autor aponta que a Holanda teria sido o primeiro Estado nação europeu, do que discordamos, haja vista a constituição do Estado português quase 300 anos antes.

${ }^{312}$ LORENZEN, Ernest G. Huber's de conflict legum. Illinois Law Review, v. 13, p. 375, 1919.

${ }^{313}$ PAUL, Joel R. Comity in international law. Harvard International Law Review, v. 32, No. 1, p. 13, Winter 1991.
} 
não poderia ser aplicada pelo foro inglês, pois ela violava a ordem pública inglesa. Lord Mansfield decidiu que a lei americana que reconhecia a escravidão não seria aplicada pela corte inglesa, por razões morais ou políticas, sendo a escravidão "so odious, that nothing can be suffered to support it, but positive law" ${ }^{, 314}$. Em resumo, Mansfield considerou a comity uma doutrina de aplicação discricionária, de forma que a lei estrangeira deveria ser sempre aplicada, desde que não violasse os princípios de direito natural ou de ordem pública.

O americano Samuel Livermore, em 1828, escreveu um ensaio sobre conflitos de leis no espaço, rejeitando explicitamente as ideias de Mansfield sobre a comity. De acordo com Livermore, o direito internacional não permite às cortes que decidam discricionariamente a aplicação do direito estrangeiro. Assim, as cortes americanas deveriam aplicar o direito estrangeiro como se fossem cortes estrangeiras ${ }^{315}$. Como um advogado atuante no novo Estado da Louisiana, recém-adquirida pelos Estados Unidos da França, Livermore defendia que os Estados não escravagistas deveriam aplicar o direito dos Estados escravagistas, nos conflitos envolvendo escravos fugidos - como foi o caso julgado por Mansfield na Inglaterra.

A posição de Livermore provocou uma posição contrária apaixonada do juiz da Suprema Corte americana Joseph Story. Seu trabalho é considerado a fundação do direito internacional americano, tamanho o impacto que sua obra provocou ${ }^{316}$. Story considerou que as ações de busca e apreensão de escravos violava a Law of Nations. ${ }^{317}$

Story bebeu na fonte de Huber e Mansfield a teoria da international comity, justificando a liberdade das cortes americanas de não aplicar o direito estrangeiro, como forma de evitar especificamente os efeitos da escravidão. Em linhas gerais, Story considerou que a comity between nations como uma "obrigação imperfeita", que não poderia ser resumida em uma regra específica ${ }^{318}$. Em síntese, Story - assim como

\footnotetext{
${ }^{314}$ Caso James Sommersett, 20 How. St. Tr. 1, 3-4 (K.B. 1772) (PAUL, Joel R., Comity in international law, cit., p. 23).

${ }^{315}$ LIVERMORE, Samuel. Dissertation on the question wich arise from the contrariety of the of different states and nations, apud PAUL, Joel R., Comity in international law, cit., p. 23.

${ }^{316}$ STORY, Joseph. Commentaries on the conflict of laws, apud PAUL, Joel R., Comity in international law, cit., p. 23.

${ }^{317}$ United States v. La Jeune Eugenie, 26 F. Cas. 832, 851 (C.C.D. Mass. 1822) (PAUL, Joel R., Comity in international law, cit., p. 23).

${ }^{318}$ BRAND, Ronald A.; JABLONSKI, Scott R. Forum non conveniens: history..., cit., p. 54.
} 
Mansfield e Huber - sustentou que a doutrina da international comity como uma permissão às cortes para negar a aplicação do direito estrangeiro sempre que houver violação à ordem pública do foro. Esses três juristas estavam particularmente preocupados com a progressiva polarização de opiniões sobre o nacionalismo, o fanatismo religioso e a escravidão. Por conta dessa radicalização progressiva, a comity permitia às cortes decidir a conveniência de aplicação do direito estrangeiro, ou quando a ordem pública doméstica deveria se sobrepor à cortesia. Em síntese, a corte seria o agente de aplicação da soberania do Estado. ${ }^{319}$

A doutrina da international comity desenvolveu-se ao longo do tempo em três principais contextos, relacionados todos ao direito internacional.

O principal deles, em que a doutrina mais se desenvolveu, trata do reconhecimento de sentenças estrangeiras ${ }^{320}$. Em 1895, no caso Hilton v. Guyol, a Suprema Corte americana definiu a comity como sendo um dever de Estado reconhecer atos legislativos, judiciários ou executivos de nações estrangeiras, tanto quanto um ato de conveniência internacional, como pelo reconhecimento dos direitos de seus próprios cidadãos como de estrangeiros que estejam sob a proteção de suas leis ${ }^{321}$. No final do século XIX, uma empresa francesa apresentou uma sentença estrangeira, proferida na França, contra um cidadão americano, a ser executada na corte americana. A Suprema Corte negou o reconhecimento da sentença estrangeira, pelo fato de a França, à época, ter se recusado a executar uma sentença americana. Em síntese, se a doutrina da comity derivava do respeito entre nações soberanas, entendeu a corte que uma soberania respondia à outra (one sovereign paid to another).

O segundo contexto é a determinação de em quais hipóteses a lei americana deve ser aplicada extraterritorialmente, isto é, por fatos ou atos ocorridos fora do território americano. Em 1993, no caso Hartford Fire Insurance Co. v. California, os réus - uma empresa americana e outra britânica - reconhecidamente violaram o Sherman Antitrust Act, ao limitar fraudulentamente a cobertura de seguro empresarial nos Estados Unidos ${ }^{322}$. A empresa inglesa alegou que o Sherman Act não poderia ser imposto a ela, pois, pela doutrina da international comity, deveriam ser aplicadas pela corte americana as leis

\footnotetext{
${ }^{319}$ PAUL, Joel R., Comity in international law, cit., p. 25.

${ }^{320}$ BRAND, Ronald A.; JABLONSKI, Scott R. Forum non conveniens: history..., cit., p. 54.

${ }^{321} 159$ U.S. 113 (1895) (PAUL, Joel R., op. cit., p. 27).

${ }^{322}$ Caso Hartford Fire Ins. Co., 509, U.S. at 769 (BRAND, Ronald A.; JABLONSKI, Scott R., op. cit., p. 55).
} 
antitrustes britânicas. O juiz Scalia invocou a Restatement (Third) of Foreign Relations Law of the United States ${ }^{323}$, que por sua vez prescreve que as decisões envolvendo jurisdição devem ser "razoáveis". De acordo com a Restatement, as cortes são obrigadas a considerar as conexões e os graus de interesse envolvendo todos os Estados afetados pela decisão a ser proferida. No caso concreto, como atividades relevantes ocorreram no Reino Unido, os réus eram britânicos e o Reino Unido possui um sistema jurídico regulando o ramo de seguros, concluiu o juiz Scalia que os Estados Unidos não detinham suficiente conexão ou interesse na causa.

O terceiro contexto da international comity relaciona-se ao não conhecimento de demandas, principalmente nos casos em que há litispendência internacional (parallel foreign litigation). Em síntese, nas hipóteses em que o reconhecimento da competência internacional pelas cortes americanas puder "ofender o relacionamento amigável com outro Estado". Nessas hipóteses, a international comity é vista como um exercício de deferência à corte estrangeira ${ }^{324}$. Essa hipótese de aplicação da international comity tem sido apontada pela doutrina como a principal diferença com a doutrina do forum non conveniens: enquanto esta última é aplicada sem que haja uma ação já proposta em jurisdição estrangeira, a primeira decorre justamente da litispendência internacional. ${ }^{325}$

\subsection{Forum shopping no âmbito do direito da União Europeia}

A maioria das regras de direito internacional privado na União Europeia foi adotada sob o amparo dos artigos 61 e 65 do Tratado de Amsterdã, de $1^{\circ}$ de maio de 1999, que atribuiu à União Europeia, de maneira expressa, a competência para "adotar medidas no âmbito da cooperação judiciária em matéria civil, em conformidade com o artigo 65" (art. 61, "c"), com a finalidade de atingir "um espaço de liberdade, de segurança e de justiça", reforçado posteriormente pelo Tratado de Lisboa, em seu artigo 81.

\footnotetext{
${ }^{323}$ Restatements of the law são enunciados oriundos de julgamentos, publicados pela American Law Institute (ALI), que por sua vez é composta por juízes, acadêmicos e advogados. Embora não sejam vinculantes, os Restatements são levados em conta como uma espécie de princípios ou regras do common law (HIXSON, Kathleen. Extraterritorial jurisdiction under the Third Restatement of Foreign Relations Law of the United States. Fordham International Law Journal, v. 12, p. 127, 1988).

${ }^{324}$ BRAND, Ronald A.; JABLONSKI, Scott R. Forum non conveniens: history..., cit., p. 55.

325 "The fact is, of course, that the application of a foreign law implies no act of courtesy, no sacrifice of sovereignty. It merely derives from a desire to do justice." (NORTH, Peter Machin; FAWCETT, J. J. Cheshire and North's private international law. 13th ed. London: Butterworths, 1999. p. 5).
} 
Atualmente, essas regras de cooperação judiciária estão previstas no Regulamento (UE) 1215/2012 do Parlamento Europeu e do Conselho, de 12.12.2012, relativo à competência judiciária, ao reconhecimento e à execução de decisões em matéria civil e comercial, também denominado Regime de Bruxelas.

Como forma de se mitigar eventuais "táticas de litigação abusivas" (conforme consta no $22^{\circ}$ considerando), o Regime de Bruxelas estabeleceu regras e exceções, e com isso permitiu uma maior clareza no estabelecimento da competência internacional dos litígios cíveis e comerciais. ${ }^{326}$

Não se aplica o Regulamento às seguintes matérias:

a) Fiscais, aduaneiras ou administrativas, nem à responsabilidade do Estado por atos ou omissões $\left(\operatorname{art.} 1^{\circ}\right.$ );

b) Ao estado e à capacidade jurídica das pessoas naturais e ao regime de bens (art. $2^{\circ}$, a);

c) Às falências e concordatas (art. $\left.2^{\circ}, b\right)$;

d) À segurança social (art. $\left.2^{\circ}, c\right)$;

e) $\grave{A}$ arbitragem (art. $\left.2^{\circ}, \mathrm{d}\right)$;

f) Às obrigações de alimentos $\left(\operatorname{art.} 2^{\circ}, e\right)$;

g) À matéria sucessória $\left(\operatorname{art.} 2^{\circ}, \mathrm{f}\right)$.

Como regra geral, a competência é baseada no domicílio do réu (art. $2^{\circ}$ ), seguindo a regra actor forum rei sequitur. ${ }^{327}$

326 CAMPUZANO DÍAZ, Beatriz. Las normas de competencia judicial internacional del reglamento 1215/2012 y los demandados domiciliados fuera de la UE: análisis de reforma. Revista Electrónica de Estudios Internacionales, v. 28, p. 3, 2014; BELL, Andrew. Forum shopping and venue in transnational litigation. Oxford: Oxford University Press, 2003. p. 55.

${ }^{327}$ Formulado por juristas romanos no fim do século III, a máxima actor sequitur forum rei é conhecida e aplicada nas mais variadas jurisdições. Segundo Fragistas, dois são os fundamentos principais dessa regra para determinação da competência internacional: em primeiro lugar, segue-se a regra interna de competência territorial, que dá a primazia do local do processo ao réu. Essa posição é manifestamente conservadora, pois favorece aquele cujo direito quer se manter (o réu), em detrimento daquele que pretende modificar o statu quo (autor); em segundo lugar, há uma razão de ordem prática, que leva em conta a satisfação do direito sub judice. A execução forçada da sentença parece ser mais eficaz no local em que o réu detenha patrimônio, e isso - via de regra - ocorre na jurisdição em que ele detém domicílio (FRAGISTAS, Charalambos N., La compétence internacionale en droit privé, cit., p. 200). 
As exceções à regra geral estão enumeradas nas seções 2 a 7 do regulamento:

a) Em matéria contratual, a competência é do Estado em que a obrigação deva ser cumprida (art. $\left.7^{\circ}, 1, a\right)$;

b) Em matéria extracontratual, onde ocorreu ou poderá ocorrer o fato danoso (art. $\left.7^{\circ}, 2\right)$;

c) Em ações fundadas em infração penal, no local em que foi antes proposta a ação criminal (art. $\left.7^{\circ}, 3\right)$;

d) Nas hipóteses de ação visando à recuperação de um objeto cultural subtraído, a competência é do tribunal do lugar em que esteja situado o bem, quando da propositura da ação (art. $\left.7^{\circ}, 4\right)$;

e) Se se tratar de um litígio relativo a uma sucursal, agência ou filial de uma pessoa jurídica, no local em que tais se situem independentemente da sede da matriz (art. $\left.7^{\circ}, 5\right)$;

f) Nas ações propostas contra um fundador, trustee ou beneficiário de um trust, a competência é domicílio do trust (art. $7^{\circ}, 6$ );

g) Nos litígios relativos à reclamação por assistência ou salvamento de uma carga ou frete, perante o tribunal em cuja jurisdição essa carga ou frete tenham sido arrestados para garantia do pagamento (art. $7^{\circ}$, a) ou poderiam ter sido arrestados, se não tivesse sido prestada caução ou outra garantia (art. $\left.7^{\circ}, \mathrm{b}\right)$;

h) Havendo mais de um réu, o autor poderá propor a ação no tribunal do domicílio de qualquer um deles (art. $\left.8^{\circ}, 1\right)$;

i) Havendo intervenção de terceiro, a competência é da jurisdição em que o feito principal tramita (art. $8^{\circ}, 2$ ), ocorrendo o mesmo com a reconvenção (art. $8^{\circ}, 3$ );

j) Em matéria contratual, se a ação puder ser apensada a uma ação em matéria de direitos reais sobre imóveis, desde que o réu seja o mesmo, a competência é o do local onde está situado o imóvel (art. $\left.8^{\circ}, 4\right)$;

k) Nos casos em que um tribunal for competente para apreciar ações envolvendo responsabilidades decorrentes da exploração ou utilização de um navio, essa corte também será competente para apreciar ações que tratem de limitação a essa responsabilidade $\left(\operatorname{art} .9^{\circ}\right)$.

Além dessas regras específicas, o regulamento também define regras em que há mais de uma alternativa de foro competente, cuja escolha cabe ao autor. São hipóteses de 
forum shopping licitamente permitido pelo legislador europeu, tendo sido considerado se tratar de hipóteses de hipossuficiência do demandante ${ }^{328}$. São as hipóteses de contratos de seguro, relações de consumo e relações trabalhistas.

Em matéria de seguros, o segurador domiciliado no território de um Estado membro pode ser demandado onde tiver domicílio (art. 11, 1, a); em outro Estado membro, onde se situe o domicílio do autor, seja ele tomador do seguro, segurado ou beneficiário (art. 11, 2, b), podendo estes ainda optar pelo local onde ocorreu o fato danoso (art. 12). Caso o segurador seja o autor da ação, ele obrigatoriamente deverá propor a ação no Estado membro em que o réu seja domiciliado (art. 14).

Nos contratos envolvendo relações de consumo, o consumidor poderá optar entre seu domicílio (art. 18, 1) e o Estado membro em que o réu estiver domiciliado (art. 18, 1, in fine). Porém, o fornecedor apenas poderá propor demanda em face do consumidor no Estado membro em que este último tenha domicílio (art. 18, 2).

Nas relações trabalhistas, o trabalhador poderá optar entre o Estado membro em que o empregador for sediado (art. 21, 1, a); no Estado em que o trabalhador habitualmente efetua seu trabalho (art. 18, 1, b, i); no Estado em que o trabalhador foi contratado (art. 18, 1, b, ii), caso o trabalhador labore em mais de um Estado membro. Por fim, o empregador apenas pode propor uma demanda contra o trabalhador no domicílio deste último (art. 22, $1)$.

Ocorrendo litispendência ou conexão internacional, todos os tribunais de diferentes Estados membros, que não seja o que foi o primeiro demandado, devem suspender a tramitação dos respectivos feitos, até que este primeiro tribunal demandado analise a regularidade de sua competência (art. 29, 1). Se esse tribunal confirmar sua própria competência, todos os demais deverão declarar-se incompetentes em favor daquele (art. 29, 3).

\footnotetext{
${ }^{328}$ Informações oriundas das instituições e dos órgãos da União Europeia: Convenção relativa à competência judiciária, ao reconhecimento e à execução de decisões em matéria civil e comercial assinada em Lugano, em 30 de Outubro de 2007 - Relatório explicativo do Professor Fausto Pocar (Titular da cátedra de Direito Internacional da Universidade de Milão). Jornal Oficial da União Europeia C 319 de 23.12.2009, p. 1-56. Disponível em: <http://eur-lex.europa.eu/legalcontent/PT/TXT/PDF/?uri=OJ:C:2009:319:FULL\&from=PT>. Acesso em: 20 jun. 2015.
} 
PARTE II 


\section{CAPÍTULO 3 - FORUM SHOPPING NO DIREITO INTERNACIONAL PRIVADO BRASILEIRO}

\subsection{Breve síntese evolutiva da competência internacional da Justiça brasileira}

A análise histórica da competência internacional brasileira mostra não ter havido impedimento ao exercício do direito de ação por parte de estrangeiros, ressalvadas premissas de ordem processual $^{329}$, como a caução prevista no artigo 835 do CPC de $1973^{330}$ e no artigo 83 do NCPC.

Valladão cita que as Ordenações do Reino, no velho direito português, deixavam claramente expresso não haver distinção entre portugueses e estrangeiros ${ }^{331}$, quando se referiam à competência que pudesse interessar a estrangeiros.

Ao invés, naquela época, alguns estrangeiros gozavam de privilégios extraordinários perante os tribunais brasileiros. Athos Gusmão Carneiro cita a criação do cargo de juiz conservador da nação britânica pelo Alvará de 4 de maio de 1808 . Não se tratava de um juiz inglês, mas de um juiz brasileiro escolhido pelos súditos ingleses residentes no Brasil, ratificado pelo embaixador ou ministro do Reino Unido e aceito pelo rei ou príncipe regente ${ }^{332}$. Na tradição portuguesa, os juízes conservadores eram uma instituição comum à época e eram nomeados com o propósito de julgar as demandas de determinados grupos de estrangeiros, entidades ou corporações. Américo Lacombe aponta que, na época da mudança da família real portuguesa para o Brasil, em meio às guerras napoleônicas, havia em Lisboa nada menos do que doze juízes conservadores: dos

\footnotetext{
${ }^{329}$ GRECO, Leonardo. A competência internacional da justiça brasileira. Revista da Faculdade de Direito de Campos, Campos dos Goytacazes, RJ, v. 6, n. 7, p. 170, dez. 2005.

330 Países membros do Mercosul, França e Espanha possuem com o Brasil tratados de cooperação regulamentando e dispensando essa restrição.

331 VALLADÃO, Haroldo, Da competência judiciária no direito internacional privado, in Estudos de direito internacional privado, cit., p. 445. Cita Valladão especificamente o Título 52 no Livro 1, que dizia: “O ouvidor da alfândega conhecerá dos feitos cíveis que perante ele se moverem entre quaisquer mercadores ou tratantes, assim naturais como estrangeiros, sobre quaisquer tratos e mercadorias, pagamentos ou entrega d'elas."

332 CARNEIRO, Athos Gusmão. O juiz conservador da nação britânica. Revista de Informação Legislativa, Brasília, v. 14, n. 56, p. 242, out./dez. 1977.
} 
hamburgueses, britânicos, franceses, espanhóis, holandeses, da Ordem de Malta, da Universidade de Coimbra, da Santa Casa de Misericórdia etc. ${ }^{333}$

Declarada a Independência, o ministro Aureliano Coutinho proclamou solenemente o Aviso de 14 de setembro de 1833, prevendo que:

[...] relativo aos estrangeiros que, não tendo propriedade, nem domicílio no Império, recorrem às nossas autoridades para o fim de fazer citar qualquer compatriota seu; tenho de comunicar à V. Exa. que, no Brasil todos os estrangeiros citam e são citados, pelas Justiças Territoriais, em qualquer parte em que se acham, transitória, ou fixamente, para se conhecer, ou julgar nos respectivos Juízos de suas demandas, ou sejam havidas com os nacionais, ou com outros estrangeiros do mesmo, ou diverso Estado, conforme a Ordenação do Liv. $1^{\circ}$, par. 52 e Liv. $3^{\circ}$ par. $3^{\circ}$.

Pimenta Bueno, em 1863, já defendia peremptoriamente a participação do estrangeiro em demandas judiciais no Brasil:

\begin{abstract}
O estrangeiro, por isso mesmo que é homem, tem tanto direito de obter justiça como qualquer homem nacional. [...] Portanto, o estrangeiro deve ser admitido como parte legítima em qualquer ação pessoal resultante do contrato ou do quase-contrato, delito ou quase-delito, qualquer que seja o lugar em que o direito teve nascimento, como se ele fosse nacional. É esse o nosso direito: os estrangeiros podem demandar ou ser demandados perante a Justiça brasileira, por nacionais ou estrangeiros, por obrigações contraídas dentro ou fora do império, desde que devam ter nele efeitos. ${ }^{334}$
\end{abstract}

A Constituição republicana de 1891, em seu artigo 72, assegurava "a nacionais e estrangeiros residentes no Estado a inviolabilidade dos direitos concernentes à liberdade, à segurança individual e à propriedade". E o Código Civil de 1917, em seu artigo 3º, definia que "a lei não distingue entre nacionais e estrangeiros quanto à aquisição e ao gozo dos direitos civis".

Porém, a Lei de Introdução de 1916 regulava a questão da competência internacional das cortes brasileiras pelo artigo 15: "Rege a competência, a forma do processo e os meios de defesa a lei do lugar, onde se mover a ação; sendo competentes sempre os tribunais brasileiros nas demandas contra as pessoas domiciliadas ou residentes

\footnotetext{
333 LACOMBE, Américo Jacobina. Ensaios brasileiros de história. Brasília, DF: Brasiliana, 1989, apud CARNEIRO, Athos Gusmão, O juiz conservador da nação britânica, cit., p. 244.

${ }^{334}$ SÃO VICENTE, José Antonio Pimenta Bueno, Marquês de, Direito internacional privado e aplicação de seus princípios com referência às leis particulares do Brasil, cit., p. 129.
} 
no Brasil, por obrigações contraídas ou responsabilidades assumidas neste ou noutro Estado."

Duas regras apareceram nesse mesmo artigo. A primeira, determinando a lei do lugar onde se promoveu a ação como a regedora da competência, da forma do processo e dos meios de defesa; a segunda, estabelecendo a competência dos tribunais brasileiros, nas demandas contra as pessoas domiciliadas ou residentes no Brasil, desde que a causa versasse sobre obrigações contraídas ou responsabilidades assumidas no Estado ${ }^{335}$. Por conta disso, havia uma recusa à homologação de sentença estrangeira, onde quer que ressaltasse a incompetência do juiz estrangeiro em face da concorrente competência da Justiça brasileira, por força da segunda parte do citado artigo 15.

Em 1928, a Convenção de Direito Internacional Privado de Havana, de 1929, chamada de Código Bustamante, previu a competência internacional em matéria civil nos artigos 318 a 339, prevendo a submissão expressa ou tácita dos litigantes ao juiz de um Estado, sempre que um deles fosse nacional daquele Estado ou tivesse nele domicílio, e salvo o direito local em contrário. Também previu que não seria admitida a submissão nas ações reais ou mistas sobre imóveis, se a lei da situação a proibisse (art. 318). Além dos casos de submissão e salvo lei local em contrário, nas ações pessoais seria competente o juiz do lugar do cumprimento da obrigação; na sua falta, o juiz do domicílio do réu ou, subsidiariamente, o juiz da sua residência (art. 323); nas ações reais sobre bens móveis, a competência seria do juiz da situação e, se esta não fosse conhecida do autor, o do seu domicílio e, à sua falta, o da residência do réu (art. 324); nas ações reais imobiliárias e nas mistas de limites e divisão de bens comuns, juiz competente seria o da situação dos bens (art. 325); havendo bens em mais de um Estado, em qualquer deles poderia ser proposta a ação, salvo se a lei da situação, referente a imóveis, o proibisse (art. 326); a litispendência, por motivo de demanda já em curso em outro Estado, poderia ser alegada, na hipótese em que a sentença que viesse a ser proferida em um deles, devesse produzir no outro os efeitos da coisa julgada (art. 394); a execução de sentença de um Estado em outro teria como pressuposto ter sido proferida por juiz competente, de acordo com as regras daquele Código (art. 423.1). ${ }^{336}$

\footnotetext{
${ }^{335}$ LOPES, Miguel Maria Serpa, Comentários à Lei de introdução ao Código Civil, cit., v. 3, p. 81.

${ }^{336}$ GRECO, Leonardo, A competência internacional da justiça brasileira, cit., p. 175.
} 
O artigo 12 da Lei de Introdução ao Código Civil de 1942 (atualmente denominada Lei de Introdução às Normas do Direito Brasileiro - LINDB, conforme determinação da Lei n. 12.376/2010) definiu a competência internacional da Justiça brasileira para as hipóteses em que o réu fosse domiciliado no Brasil ou aqui tivesse de ser cumprida a obrigação. E no parágrafo $1^{\circ}$, declarou a competência exclusiva da Justiça brasileira para as "ações relativas a imóveis situados no Brasil".

O Código de Processo Civil 1939 não previu a eleição de foro estrangeiro, mas boa parte da doutrina reconhecia tal possibilidade ${ }^{337}$. Segundo Leonardo Greco, a Justiça brasileira também se considerava competente para as ações relativas a imóveis situados no exterior, desde que a isso não se opusesse o direito interno do Estado da situação do bem, pois essa competência estava expressamente facultada no parágrafo $1^{\circ}$ do artigo 136 do CPC de 1939. A opção pelo foro do cumprimento da obrigação, tenha sido ela constituída no exterior ou no Brasil, seria o lugar do seu cumprimento. As obrigações extracontratuais deveriam ser cumpridas no forum delicti. No caso de conflito entre o foro do domicílio do réu e o do cumprimento da obrigação, este deveria prevalecer como lei especial ${ }^{338}$. Liebman defendeu à época que, na ausência de domicílio (ou residência) do réu no Brasil, deveria aplicar-se o parágrafo $1^{\circ}$ do artigo 134 do CPC de 1939, que por sua vez previa o domicílio ou residência do autor como critério de competência; por outro lado, se o autor fosse domiciliado ou residente no exterior, a demanda poderia ser ajuizada perante qualquer juízo. $^{339}$

O CPC de 1973 regulou a competência internacional nos artigos 88 a 90, estabelecendo duas espécies de regras: as de competência internacional concorrente (art. 88) e as de competência internacional exclusiva (art.89). O NCPC, por sua vez, manteve a dicotomia entre as hipóteses de competência internacional concorrente (arts. 21 e 22) e exclusiva (art. 23).

No âmbito do Mercosul, o Brasil firmou o Protocolo de Las Leñas sobre Cooperação e Assistência Jurisdicional, de 1992, o Protocolo de Buenos Aires sobre

\footnotetext{
${ }^{337}$ TENÓRIO, Oscar. Lei de Introdução ao Código Civil brasileiro. 2. ed. aum. Rio de Janeiro: Borsoi, 1955. p. 393.

338 GRECO, Leonardo, A competência internacional da justiça brasileira, cit., p. 176; e TENÓRIO, Oscar. Direito internacional privado. Rio de Janeiro: Freitas Bastos, 1970. v. 2, p. 365.

${ }^{339}$ LIEBMAN, Enrico Tullio. Os limites da jurisdição brasileira. In: brasileiro. São Paulo: Saraiva, 1947. p. 25. . Estudos sobre o processo civil
} 
Jurisdição Internacional em Matéria Contratual, de 1994, e o Protocolo de São Luiz sobre Responsabilidade Civil Emergente de Acidentes de Trânsito, de 1996.

O Protocolo de Las Leñas, de 1992, dispõe que o reconhecimento e execução das sentenças e laudos arbitrais pelas autoridades judiciárias dos Estados membros do Mercosul se dará pelo procedimento mais simples do cumprimento de cartas rogatórias, dispensando o trânsito em julgado e todas as demais formalidades normalmente exigidas na homologação de sentenças estrangeiras (art. 19). Assim, o Brasil passou a aceitar cartas rogatórias executórias, anteriormente repudiadas pela jurisprudência uniforme do $\mathrm{STF}^{340}$. As sentenças e os laudos arbitrais terão eficácia extraterritorial nos Estados partes sempre que emanarem de órgão jurisdicional ou arbitral competente, segundo as normas do Estado requerido sobre jurisdição internacional (art. 20). Nas hipóteses em que se tratar de sentença ou laudo arbitral entre as mesmas partes, fundamentado nos mesmos fatos, e que tenha o mesmo objeto de outro processo judicial ou arbitral no Estado requerido, seu reconhecimento e sua executoriedade dependerão de que a decisão não seja incompatível com outro pronunciamento anterior ou simultâneo proferido no Estado requerido, não se procedendo à execução quando se houver iniciado um procedimento entre as mesmas partes, fundamentado nos mesmos fatos e sobre o mesmo objeto, perante qualquer autoridade jurisdicional do Estado requerido, anteriormente à apresentação da demanda no Estado requerente (art. 22).

Muito embora a redação desse dispositivo não tenha sido das mais felizes, verificase a previsão da litispendência internacional, derrogatória do artigo 24 do NCPC, embora a doutrina brasileira divirja sobre seus efeitos (ou seja, uma corrente entende que a litispendência internacional no âmbito do Mercosul fundamenta a extinção do segundo processo, enquanto outra corrente entende ser o caso de mero impedimento à execução da sentença fora do território do Estado em que vier a ser proferida. Esse assunto será retomado oportunamente.

O Protocolo de Buenos Aires sobre Jurisdição Internacional em Matéria Contratual, de 1994, previu a eleição do foro de um ou outro Estado nos contratos internacionais de matéria civil ou comercial (art. $4^{\circ}$ ); também previu prorrogação da competência

\footnotetext{
${ }^{340}$ GRECO, Leonardo, A competência internacional da justiça brasileira, cit., p. 187.
} 
internacional se o réu se submeter voluntariamente, de forma positiva (e não ficta, ou seja editalícia ou o que lhe faça as vezes), à jurisdição do Estado escolhida pelo autor (art. $\left.6^{\circ}\right)$; na ausência de previsão contratual prévia, a competência internacional, à escolha do autor, será a do foro do cumprimento do contrato, do foro do domicílio do réu ou do foro do domicílio do autor ou o da sua sede social, quando demonstrar que cumpriu a sua prestação $\left(\right.$ art. $7^{\circ}$ ). Esta última previsão foi aplaudida por Erick Jayme, e será comentada com mais vagar oportunamente. $\mathrm{O}$ artigo $8^{\circ}$ definiu em várias hipóteses as possibilidades de "lugar do cumprimento do contrato"; o artigo $9^{\circ}$ definiu o domicílio do demandado, em sendo ele pessoa natural ou jurídica. Nas demandas propostas entre sócios, serão competentes os juízes da sede principal da administração (art. 10). As pessoas jurídicas com sede em um Estado, e que celebrem contratos em outro, podem ser demandadas nessa última jurisdição; nas hipóteses de litisconsórcio passivo, terá jurisdição o Estado do domicílio de qualquer deles; as demandas sobre garantias e a intervenção de terceiros podem ser propostas incidentalmente no juízo da causa principal (art. 11), o mesmo ocorrendo com a reconvenção, se derivar do mesmo ato ou fato que serviu de base para a demanda principal (art. 13). Importante mencionar que as regras desse Protocolo prevalecem sobre o Protocolo de Las Leñas, no reconhecimento e execução de sentenças e laudos arbitrais em matéria civil ou comercial (art. 14).

O Protocolo de São Luiz, de 1996, sobre Responsabilidade Civil por Acidentes de Trânsito estabeleceu no artigo $7^{\circ}$ que as ações de indenização a que se refere poderão ser propostas, à escolha do autor, nos tribunais do Estado parte onde ocorreu o acidente, do domicílio do demandado ou do domicílio do próprio demandante, repetindo a regra do direito interno brasileiro, constante do artigo 100, parágrafo único, do CPC de 1973, e que encontra eco no artigo 53, V, do NCPC.

Por fim, o Protocolo de Ouro Preto de Medidas Cautelares do Mercosul, de 1994, permite a cooperação entre as autoridades dos Estados partes em medidas de urgência, dispensando a tramitação por via diplomática e o procedimento de homologação da sentença estrangeira entre os juízes das zonas fronteiriças (art. 19).

Há de se mencionar que os acordos bilaterais de cooperação judiciária do Brasil com a Argentina (Brasília, 1991) e com o Uruguai (Montevidéu, 1992) contêm disposições sobre a eficácia extraterritorial das sentenças judiciais e laudos arbitrais de cada Estado no 
território do outro, desde que emanem de um órgão competente, de acordo com as normas do Estado requerido sobre jurisdição internacional, bem como sobre litispendência e coisa julgada, decorrente de litígios fundados nos mesmos fatos e com o mesmo objeto.

\subsection{Competência internacional concorrente ou exclusiva}

O NCPC de 2015 regulou a competência internacional nos artigos 21 a 23, estabelecendo duas espécies de regras: as de competência internacional concorrente (arts. 21 e 22) e as de competência internacional exclusiva (art. 23), seguindo a tradição vigente no CPC de 1973.

Na primeira (a competência internacional concorrente), a lei processual brasileira define sem exclusividade as hipóteses em que a demanda poderá ser proposta perante os tribunais pátrios. Em resumo, haverá jurisdição das cortes brasileiras se no Brasil o réu tiver domicílio, se aqui tiver de ser cumprida a obrigação ou se a ação se originar de fato ocorrido ou ato praticado no Brasil (art. 21). Na sequência, o artigo 22 do NCPC inovou em relação ao CPC de 1973, ao incluir a competência concorrente da Justiça brasileira para julgar as ações de alimentos, desde que o credor tenha domicílio ou residência no Brasil; ou desde que o réu mantenha vínculos no Brasil, tais como posse ou propriedade de bens, recebimento de renda ou obtenção de benefícios econômicos; ou, finalmente, nos casos decorrentes de relações de consumo, desde que o consumidor tenha domicílio ou residência no Brasil.

Essa competência é concorrente, pois nessas mesmas hipóteses, caso alguma outra jurisdição alienígena se der por competente de acordo com suas normas vigentes, os artigos 21 e 22 do NCPC não serão obstáculo a que a decisão estrangeira seja aqui homologada e executada, como se fosse uma decisão de um dos nossos tribunais, como já professava o artigo 88 do CPC de 1973. Sobre este último dispositivo, Entendeu à época Leonardo Greco, citando Barbosa Moreira, que o reconhecimento da decisão originária de outro Estado somente seria admissível entre nós se o foro estrangeiro fosse escolhido pelas partes ou se o réu tivesse se submetido voluntariamente ao foro estrangeiro, ali exercendo o seu direito de defesa ${ }^{341}$. Porém, conforme mencionado anteriormente, a falta de

${ }^{341}$ GRECO, Leonardo, A competência internacional da justiça brasileira, cit., p. 186. 
submissão voluntária não afasta a jurisdição estrangeira e futura homologação dessa sentença no Brasil, a não ser na hipótese de nulidade da citação do réu.

A homologação da sentença estrangeira é um ato formal que permite a ela surtir efeitos em todo o território brasileiro, e aqui será aqui executada como se fosse uma sentença de um tribunal judiciário nacional (art. 515, VIII, do NCPC). ${ }^{342}$

Essa homologação ocorrerá ainda que no Brasil esteja pendente ação idêntica, porque o artigo 24 do NCPC (seguindo a redação do art. 90 do CPC de 1973) exclui os efeitos da litispendência internacional e, a partir da homologação pelo STJ, extinta será a causa aqui proposta, como um dos efeitos da coisa julgada. Somente o trânsito em julgado anterior da sentença nacional impedirá a homologação da sentença estrangeira ${ }^{343}$. Isso faz com que o sistema processual brasileiro tenha privilegiado o aspecto da velocidade na obtenção da coisa julgada como o critério definidor de qual sentença gerará efeitos no Brasil, ou seja, se a estrangeira ou a nacional. ${ }^{344}$

Homologada no Brasil a sentença condenatória ou arbitral estrangeira, poderá ela permitir o início da fase de cumprimento de sentença perante o juiz federal competente, observadas as regras do NCPC (art. 516, III). Aliás, o NCPC inovou em relação ao CPC de 1973, ao indicar que a execução da sentença, de um modo geral (excluindo-se aquelas proferidas em competência originária por tribunais de segunda ou terceira instância, e incluídas as execuções de sentença estrangeira), poderão ser propostas no juízo do atual domicílio do executado, do juízo em que houver bens sujeitos à execução ou do juízo do local onde deva ser executada a obrigação de fazer ou não fazer, casos em que a remessa dos autos do processo será solicitada ao juízo de origem.

\footnotetext{
${ }^{342}$ MOREIRA, José Carlos Barbosa, Problemas relativos a litígios internacionais, in Temas de direito processual: quinta série, cit., p. 140.

${ }^{343}$ MOREIRA, José Carlos Barbosa, Problemas relativos a litígios internacionais, in Temas de direito processual: quinta série, cit., p. 141.

${ }^{344} \mathrm{O}$ artigo 22 do Protocolo de Las Leñas e o Regime de Bruxelas-Lugano, vigente na União Europeia, ao invés, privilegiou o critério da velocidade na propositura da demanda, pela da regra first-come, first-served ("primeiro a chegar, primeiro a ser servido"), que significa uma prioridade exclusiva da primeira jurisdição que receber uma demanda (EISENGRAEBER, Julia. Lis alibi pendens under the Brussels I Regulation: how to minimise 'torpedo litigation' and other unwanted effects of the 'first-come, first-served' rule. 2004. Dissertation (Master of Law in International Business Law) - Centre for European Legal Studies, University of Exeter, Exeter, UK, 2004. p. 15. (Papers in European Law, No. 16).
} 
No artigo 23 do NCPC taxativamente enumera os casos de competência internacional exclusiva da Justiça brasileira, ou seja, nas hipóteses de se tratar de ação relativa a imóvel situado no Brasil ou de inventário e partilha de bens situados em território pátrio. Além desses casos, o artigo 63 do NCPC prevê a competência exclusiva da Justiça brasileira para apreciar os litígios em que houve eleição de foro brasileiro pelas partes. Em todos esses casos, à falta de um tratado internacional ou de um acordo bilateral que regule a matéria, se a causa tiver sido proposta ou decidida em outro Estado, a sentença não poderá ser executada no Brasil.

A competência internacional exclusiva determina que as sentenças estrangeiras que tenham tratado do tema não possam no Brasil gerar efeitos, independentemente da concorrência de quaisquer das circunstâncias dos artigos 21 e 22 do NCPC.

Declarada a incompetência internacional da Justiça brasileira, o juiz não declinará de sua competência, nem remeterá os autos ao juízo de outro Estado, pelo princípio da plenitudo jurisdictionis, mas o processo será extinto sem julgamento do mérito (art. 485 IV do NCPC), cabendo ao autor renovar a propositura da ação perante o juízo internacionalmente competente.

Importante questão relaciona-se ao conflito positivo de jurisdições, em que ambas ou pelo menos uma das jurisdições envolvidas defina-se como exclusiva, como é o caso do artigo 24 do NCPC.

Sob o mesmo tema quanto ao CPC de 1973, entendeu Leonardo Greco que a eventual ação proposta no estrangeiro deveria ser julgada extinta justamente pela ausência de jurisdição, e não pelo princípio da efetividade, que por sua vez geraria a inutilidade do provimento no estrangeiro. E fundamenta seu entendimento pelo fato de a lei de cada Estado não poder conferir aos seus órgãos jurisdicionais uma parcela de jurisdição que exceda dos limites em que a própria soberania estatal se exerce ${ }^{345}$. Essa posição parece confundir a causa e suas consequências, na medida que o juiz, ao exercitar sua jurisdição, verificará se a futura coisa julgada será compatível com o sistema jurídico estrangeiro, dentro de uma análise binomial de necessidade-utilidade, sem que isso macule as regras de

${ }^{345}$ GRECO, Leonardo, A competência internacional da justiça brasileira, cit., p. 188. 
jurisdição internacional que permitiram a esse mesmo juiz receber a causa. E isso se relaciona com uma das condições da ação: a possibilidade jurídica do pedido, que não se confunde com o poder estatal de que está o juiz investido (jurisdição).

\subsection{Liberdade e poder discricionário}

O ordenamento jurídico disciplina o comportamento das diversas posições ocupadas pelos sujeitos processuais. E o estudo das situações e posições jurídicas das partes (subjetivas) surgiu com a evolução do estudo da natureza do processo, ou seja, pela análise dos atos praticados no decorrer da lide e das consequentes relações existentes entre os diversos sujeitos processuais.

Para Goldschmidt, o direito possui um caráter dinâmico a partir do processo, de maneira que as definições do direito privado não mais seriam aplicáveis. Os vínculos jurídicos oriundos do processo consistiriam em situações jurídicas, representadas pelas chances (ou também expectativas, possibilidades, perspectivas ou ônus) assumidas pelas partes em relação ao provimento final. ${ }^{346}$

Carnelutti, por sua vez, centrou-se no conceito de lide, que corresponde ao conflito de interesses qualificado pela pretensão de um dos interessados e pela resistência do outro, sendo a função do processo a justa composição da lide ${ }^{347}$. Logo, a relação jurídica seria um conflito de interesses juridicamente regulado, num complexo de fenômenos. O autor anteviu todo um arcabouço de categorias subjetivas processuais: direitos subjetivos, poderes, faculdades, ônus, deveres e sujeições ${ }^{348}$. Sem negar importância à evolução da processualística moderna, a conceituação de Carnelutti guarda muita afinidade com os propósitos deste trabalho.

Independentemente da teoria adotada quanto à natureza do processo, é reconhecida a existência de relações jurídicas complexas entre os sujeitos processuais. Liebman afirmou que as normas processuais têm como destinatários os sujeitos, a quem atribuem

\footnotetext{
${ }^{346}$ GOLDSCHMIDT, James. Derecho procesal civil. Barcelona: Labor, 1936. p. 9.

${ }^{347}$ CARNELUTTI, Francesco. Sistema de diritto processuale civile. Padova: CEDAM, 1936. v. 1, p. 44.

${ }^{348}$ Ibidem, v. 1, p. 56.
} 
posições jurídicas subjetivas que, por sua vez, compõem o conteúdo da relação jurídica processual. $^{349}$

Além do sujeito, costuma-se fazer referência à conduta, ao comportamento, enfim, aos atos emanados desse sujeito. A situação subjetiva diz respeito a uma determinada conduta abstrata, ou melhor, a um comportamento hipotético previsto na lei, atribuído a um determinado sujeito. ${ }^{350}$

As situações jurídicas subjetivas costumam ser divididas em duas categorias, de acordo com a conduta expressa em cada uma delas: situações jurídicas ativas e situações jurídicas passivas.

Carnelutti distinguiu a situação jurídica ativa da passiva pela proteção (situação ativa) ou subordinação (situação passiva) de um determinado interesse a partir da ótica da norma jurídica. ${ }^{351}$

As situações subjetivas ativas estão relacionadas às permissões concedidas pelo sistema jurídico, visando a que se realize determinado ato. Dentre tais situações, estão a faculdade (classificada por Carnelutti como uma situação "neutra", e não ativa), que corresponde a uma conduta permitida que se exaure na esfera jurídica do próprio agente, e o poder, que é a conduta permitida que se resolve numa atividade destinada a modificar a esfera jurídica alheia. ${ }^{352}$

Em linhas gerais, a faculdade é uma conduta lícita, cuja particularidade é exaurir-se na esfera jurídica do próprio sujeito, ao contrário do poder, cuja qualidade é interferir na esfera jurídica alheia.

\footnotetext{
${ }^{349}$ LIEBMAN, Enrico Tullio, Manual de direito processual civil, cit., v. 1, p. 330.

${ }^{350}$ ABDO, Helena Najjar, Abuso do processo, cit., p. 61.

${ }^{351}$ CARNELUTTI, Francesco, Sistema di diritto processuale civile, cit., v. 1, p. 56. Helena Abdo anota que essa orientação não diverge da doutrina mais moderna, segundo a qual a distinção entre as situações subjetivas depende da valoração que a norma confere ao modelo de conduta, ou seja, se a conduta é lícita ou ilícita (ABDO, Helena Najjar, Abuso do processo, cit., 65).

352 CINTRA, Antônio Carlos de Araújo; GRINOVER, Ada Pellegrini; DINAMARCO, Candido Rangel, Teoria geral do processo, cit., p. 281.
} 
Nas palavras de Dinamarco, são raras as condutas que se resolvem exclusivamente em faculdades processuais puras ${ }^{353}$. Helena Abdo cita como exemplo a faculdade de dar ao ato processual a forma que se desejar, desde que a lei não exija forma determinada (art. 154 do CPC de 1973), ou a faculdade de apresentar a defesa no primeiro ou no último dia do prazo. ${ }^{354}$

O poder também tem como característica a permissão de uma conduta. Porém, é diferente da faculdade, na medida que tal permissão liga-se com supremacia, e não com liberdade. E, como consequência jurídica, normalmente traz situações de dever perante um outro sujeito que não detém o mesmo poder. Assim, ao exercer o poder de ação, o autor cria para o Estado o dever de processar a demanda. ${ }^{355}$

De outro lado, as situações subjetivas passivas relacionam-se a uma necessidade, a qual se resolve com um sacrifício ou, por assim dizer, na subordinação de um interesse. Entre tais situações passivas estão o dever (exigência de um determinado comportamento), o ônus (faculdade cujo exercício é necessário para a consecução de um interesse) e a sujeição (necessidade de obedecer a um comando). ${ }^{356}$

Existe uma correspondência entre as diversas situações subjetivas, a partir da óptica da teoria da relação processual, como aponta Liebman ${ }^{357}$. Do mesmo modo, Carnelutti afirmou que o poder (situação ativa) tem correspondência com a sujeição (situação passiva), o mesmo ocorrendo entre a faculdade e o dever. ${ }^{358}$

Em síntese, dentro da teoria da relação processual, o forum shopping encontra-se na posição de poder, na medida que seu exercício causa interferência direta na esfera jurídica do demandado, que se submete à jurisdição escolhida pelo demandante, ao menos num primeiro momento.

\footnotetext{
${ }^{353}$ DINAMARCO, Cândido Rangel. Instituições de direito processual civil. São Paulo: Malheiros, 2001. v. 1. p. 203.

${ }^{354}$ ABDO, Helena Najjar, Abuso do processo, cit., 66.

${ }^{355}$ CARNELUTTI, Francesco, Sistema di diritto processuale civile, cit., v. 1, p. 57.

${ }_{356}^{356}$ ABDO, Helena Najjar, Abuso do processo, cit., 66; e CARNELUTTI, Francesco, op. cit., v. 1, p. 57.

${ }^{357}$ LIEBMAN, Enrico Tullio. L'azione nella teoria del processo civile. In: SCRITTI giuridici in onore di Francesco Carnelutti. Padova: CEDAM, 1950. v. 2, p. 449.

${ }^{358}$ CARNELUTTI, Francesco, op. cit., v. 1, p. 55. Helena Abdo aponta que Carnelutti não explica a posição correspondente ao ônus, possivelmente ligando esse conceito ao dever (ABDO, Helena Najjar, op. cit., p. 57).
} 
Esse poder do demandante, que encontra guarida no princípio do acesso à Justiça, e pelo seu mero exercício a priori, não parece violar os limites formais (direitos processuais da parte contrária) e os limites de conteúdo (relacionados às alegações das partes e ao dever de veracidade). ${ }^{359}$

Fora dos limites formais e dos limites de conteúdo, existe uma grande margem de atuação, a partir da qual quaisquer das partes exercem as respectivas situações jurídicas subjetivas (faculdades, ônus, poderes e deveres). No dizer de Helena Abdo, esse "espaço de manobra" é o reflexo processual das importantes garantias constitucionais da liberdade e da legalidade. ${ }^{360}$

Os litigantes podem usar e dispor livremente de suas situações jurídicas ativas e passivas, atuando como e quando desejarem ou omitindo-se, se assim entenderem conveniente, considerados sempre os limites legais e constitucionais, como adverte Dinamarco. ${ }^{361}$

Essa opção que dispõe o litigante internacional ao escolher a jurisdição que melhor lhe aprouver está intimamente relacionada à compreensão do caráter instrumental do processo e de seus vários escopos e finalidades. ${ }^{362}$

O processo é um instrumento destinado à consecução de determinados fins. E esses mesmos fins estão refletidos nos escopos da jurisdição, os quais deixam transparecer os valores sociais e políticos do Estado, bem como o comprometimento do sistema processual com os objetivos e o conteúdo das normas de direito material. A perspectiva instrumental propõe a revisão dos conceitos e o estudo dos institutos processuais a partir de suas finalidades gerais e específicas, privilegiando os resultados práticos do processo. ${ }^{363}$

${ }^{359}$ CARNELUTTI, Francesco. Diritto e processo. Napoli: Morano, 1958. p. 204.

${ }^{360}$ ABDO, Helena Najjar, Abuso do processo, cit., p. 77.

${ }^{361}$ DINAMARCO, Candido Rangel, Instituições de direito processual civil, cit., v. 1, p. 228.

${ }^{362}$ Vale neste momento refletir sobre as conhecidas e importantes lições sobre a instrumentalidade do processo, visando a compreender suas finalidades, tanto dentro do sistema processual, quanto, particularmente, dos instrumentos de tutela postos à disposição das partes, inclusive no âmbito internacional.

363 CINTRA, Antônio Carlos de Araújo; GRINOVER, Ada Pellegrini; DINAMARCO, Candido Rangel, Teoria geral do processo, cit., p. 43. 
Dinamarco afirma que a jurisdição possui três escopos: o social, o político e o jurídico $^{364}$. No sistema processual se percebe de antemão a função de eliminar os conflitos ("como fenômeno psíquico decorrente da carência de um bem desejado") e pacificar a sociedade. Assim, a missão pacificadora não é por si própria suficiente, pois necessita do elemento justiça no caso concreto. O Estado tem o dever de prestar a tutela jurisdicional e proferir decisões que tratam a justa composição da lide, fazendo com que o escopo social corresponda à pacificação com justiça no caso concreto. ${ }^{365}$

Pode-se emprestar a expressão de Kazuo Watanabe quanto à litigiosidade contida no âmbito internacional, fazendo com que o Poder Judiciário de cada Estado assuma e neutralize os pontos de insatisfação social, numa instrumentalidade internacional do processo.

Se a jurisdição tem objetivos que se confundem com os do próprio Estado, isso é a expressão de seu poder. E na busca do bem da vida e da justiça, o Estado precisa buscar objetivos similares e que pertençam à mesma ordem de valores em seu âmbito, em seu sistema. É esse o escopo político do processo, que abarca o poder jurisdicional do Estado, ante às decisões imperativas sobre todos os conflitos que lhe são apresentados, mediante os valores da liberdade (garantias individuais e liberdades públicas) ${ }^{366}$ e a participação efetiva dos cidadãos nos destinos da sociedade internacional.

Ao final, há o escopo jurídico, de perfil técnico, e que equivale à atuação da vontade concreta da lei, que revela uma profunda relação de instrumentalidade e interdependência entre o processo e o direito material.

A análise do forum shopping dentro da visão instrumentalista, delimitada pelos princípios positivos e negativos da jurisdição internacional, servirá como parâmetro para a identificação do fenômeno como direito potestativo do demandante ou como abuso do direito processual.

\footnotetext{
364 “A jurisdição não tem um escopo, mas escopos (plural); é muito pobre a fixação de um escopo exclusivamente jurídico, pois o que há de mais importante é a destinação social e política do exercício da jurisdição." (DINAMARCO, Cândido Rangel, A instrumentalidade do processo, cit., p. 317).

${ }^{365}$ Ibidem, p. 164.

${ }^{366}$ Ibidem, p. 176.
} 


\subsection{Manifestação do forum shopping em seus diversos níveis no direito internacional privado brasileiro}

Metodologicamente, o estudo do forum shopping se dá, em primeiro lugar, pela escolha da jurisdição em que tramitará o processo, ou seja, se a nacional ou a estrangeira, e os efeitos dali decorrentes. Em segundo lugar, há que se analisar os efeitos da tramitação do processo, tanto em nível nacional como internacional. Finalmente, em terceiro lugar, interessa estudar os efeitos da coisa julgada no plano doméstico e no internacional.

\subsubsection{A escolha da jurisdição}

Como já mencionado anteriormente, as regras processuais brasileiras disciplinam expressamente as hipóteses de competência dos tribunais nacionais nos artigos 21 a 23 do NCPC. Especificamente, os artigos 21 e 22 preveem os casos de competência concorrente, que por sua vez daria ao demandante a opção de propor a demanda em solo brasileiro.

As hipóteses de competência concorrente previstas no artigo 21 são três: (a) o domicílio do réu no Brasil (actor sequitur forum rei); (b) se no Brasil estiver o local do cumprimento da obrigação; e (c) se o Brasil for o local onde ocorreu o fato ou se praticou o ato em que se embasa a ação.

Do mesmo modo, três são as hipóteses do artigo 22: (a) casos de ações de alimentos, (b) os decorrentes de relação de consumo ou (c) quando houver um pacto de eleição de foro brasileiro, sendo que, nessa última hipótese tratar-se-á de competência exclusiva da Justiça brasileira. Na hipótese de ações de alimentos, o alimentado poderá optar pela Justiça brasileira em duas hipóteses: (1) caso o credor tenha domicílio ou residência no Brasil ou (2) o réu mantiver vínculos no Brasil, tais como posse ou propriedade de bens, recebimento de renda ou obtenção de benefícios econômicos. No caso das ações envolvendo relações de consumo, basta ao consumidor residir ou ser domiciliado no Brasil para ter como opção a Justiça brasileira. Finalmente, como última hipótese do artigo 22 do NCPC, foi consagrada em definitivo a autonomia da vontade das partes em eleger expressamente a jurisdição brasileira para resolver o litígio. 
Os efeitos da escolha da jurisdição brasileira pela prática do forum shopping podem se dar em três níveis.

Num primeiro nível, o demandante escolhe unilateralmente certa jurisdição, visando à aplicação das regras de direito internacional privado do foro.

Num segundo nível, o demandante utiliza-se de um acordo previamente firmado com outro litigante, em que se anteviu a jurisdição competente e as regras de direito a serem aplicadas (cláusula de eleição de foro e, eventualmente, de lei aplicável).

Finalmente, num terceiro nível, o demandante, já munido de uma sentença estrangeira transitada em julgado (rectius: coisa julgada internacional), busca a aplicação desses efeitos no foro.

\subsubsection{Primeiro nível de forum shopping: escolha da jurisdição para aplicação do método de direito internacional privado}

No primeiro nível de forum shopping, o demandante busca certa jurisdição objetivando a aplicação do direito material que lhe é supostamente mais favorável, de acordo com as regras de conexão previstas no direito internacional privado do foro.

Para que se dê essa hipótese no Brasil, há que se combinar os critérios de competência previstos nos artigos 21 e 22 do NCPC com os elementos de conexão estabelecidos na LINDB, que por sua vez direcionam a solução do litígio ao direito nacional ou estrangeiro - mais adequando aos interesses do demandante.

O primeiro desses elementos de conexão, no Brasil, é o domicílio (lex domicilii), previsto no artigo $7^{\circ}$ da LINDB, que prevê expressamente que "a lei do país em que for domiciliada a pessoa determina as regras sobre o começo e o fim da personalidade jurídica, o nome, a capacidade e os direitos de família”. Em síntese, sendo a parte domiciliada no Brasil, para efeitos do artigo $7^{\circ}$, aplicar-se-á a lei brasileira. O domicílio, portanto, aparece como um vínculo jurídico que submete o sujeito de direito ao ordenamento jurídico 
específico, independentemente de sua origem ou nacionalidade ${ }^{367}$. Maristela Basso exemplifica as hipóteses em que o juiz buscará o direito aplicável na jurisdição de domicílio das partes, tais como a investigação sobre o estado dos cônjuges que constituíram vínculo matrimonial no estrangeiro, quando deve examinar a capacidade do devedor que celebrou um contrato de financiamento com uma instituição financeira sediada na Espanha, ou daquele indivíduo que adquiriu livros e discos compactos (CDs) de uma loja atuante no comércio eletrônico ${ }^{368}$. Em todas essas hipóteses, estando a parte domiciliada no Brasil, aplicar-se-á pelo juiz nacional o direito brasileiro.

Em 2003, o STJ, em ação de investigação de paternidade proposta por uma portuguesa em face de seu suposto pai verdadeiro, também português, e em face de outras duas portuguesas, representantes de seu suposto pai ilegítimo (ou seja, que a havia registrado como filha sem o ser), qualificou a relação jurídica controvertida como sendo de direito de família e aplicou o artigo $7^{\circ}$ da LICC, remetendo o direito brasileiro como o aplicável, já que tanto a autora como alguns dos réus (no caso, as herdeiras do pai ilegítimo) tinham domicílio no Brasil. ${ }^{369}$

O segundo elemento de conexão é o lugar da situação dos bens (lex rei sitae), previsto no artigo $8^{\circ}$ da LICC. Segundo a redação do artigo, "para qualificar os bens e regular as relações a eles concernentes, aplicar-se-á a lei do país em que estiverem situados". Ocorre que o artigo 23 do NCPC, seguindo a redação do artigo 89 do CPC de 1973 determina que as cortes brasileiras sejam exclusivamente competentes para apreciar demandas envolvendo bens imóveis do Brasil, o que limita a prática de forum shopping exclusivamente a bens móveis. Porém, para que se aplique a lei brasileira, esses mesmos bens móveis deverão estar localizados no Brasil ${ }^{370}$. Nos casos em que os bens móveis estejam em trânsito ou tenham mobilidade intensa, o que dificultaria sua localização no espaço, o artigo $8^{\circ}$, parágrafo $1^{\circ}$, da LINDB afasta o critério da lex rei sitae em favor da

\footnotetext{
${ }^{367}$ A lex domicilii, regendo o estatuto pessoal, atendeu convenientemente a conveniência do Brasil, por ser ao menos, até poucas décadas - um país de imigração. Dessa forma, o direito nacional prefere sujeitar o estrangeiro aqui domiciliado à sua lei, integrando-o à vida brasileira, sem a necessária subordinação política (ESPÍNOLA, Eduardo; ESPÍNOLA FILHO, Eduardo. Lei de Introdução ao Código Civil brasileiro comentado. Rio de Janeiro: Freitas Bastos, 1943. v. 1, p. 28; CASTRO, Amilcar de, Direito internacional privado, cit., v. 1, p. 201; e STRENGER, Irineu, Direito internacional privado, cit., p. 493).

${ }^{368}$ BASSO, Maristela. Curso de direito internacional privado. São Paulo: Atlas, 2009. p. 157. ${ }^{369}$ STJ - REsp n. 512.401/SP.

370 A qualificação dos bens é territorial, pois lhes são aplicadas as leis do país onde estão situados (TENÓRIO, Oscar. Direito internacional privado. Rio de Janeiro: Freitas Bastos, 1967. v. 1. p. 409).
} 
regra do domicílio do proprietário. É a regra mobilia sequentur personam, pela qual os bens móveis seguem o seu titular ${ }^{371}$. Por fim, quanto aos bens intangíveis, tais como os direitos autorais, a doutrina tem apontado para a aplicação do direito do local onde se exploram economicamente tais bens ou, sendo muitos os lugares, a lei do foro onde o direito tenha sido violado. ${ }^{372}$

O terceiro elemento de conexão remete ao lugar em que a obrigação foi constituída (locus regit actum), disciplinado no artigo $9^{\circ}$ da LINDB. Assim, conforme o caput, para qualificar e reger as obrigações, aplicar-se-á a lei do Brasil, se aqui a obrigação foi constituída. O páragrafo $1^{\circ}$ do artigo $9^{\circ}$ determina que nas hipóteses em que a obrigação deva ser cumprida no Brasil, e que dependam de forma essencial, será esta observada, admitidas as peculiaridades da lei estrangeira quanto aos requisitos extrínsecos do ato. Finalmente, o parágrafo $2^{\circ}$ determina que seja considerada como constituída a obrigação no lugar em que residir o proponente. A regra do locus regit actum é compreendida tanto para as obrigações contratuais como para as extracontratuais (locus regit actum e lex loci delicti). ${ }^{373}$

O Tribunal de Justiça do Rio Grande do Sul, em 2015, teve a oportunidade de julgar uma ação de indenização movida por um motociclista uruguaio, em face de um motorista gaúcho, por uma colisão ocorrida no Uruguai. O tribunal brasileiro, após confirmar sua competência para o julgamento do caso - por se tratar de competência concorrente com a justiça uruguaia - qualificou a lide como uma obrigação extracontratual, levando a solução do caso às leis civis uruguaias, nos termos do artigo $9^{\circ}$ da LINDB. $^{374}$

${ }^{371}$ ESPÍNOLA, Eduardo; ESPÍNOLA FILHO, Eduardo, Lei de Introdução ao Código Civil brasileiro comentado, cit., v. 2, p. 451; DINIZ, Maria Helena. Lei de Introdução ao Código Civil. São Paulo: Saraiva, 2010. p. 317.

372 BASSO, Maristela. Direito internacional da propriedade intelectual. Porto Alegre: Livraria do Advogado, 2000, p. 65.

${ }^{373}$ TENÓRIO, Oscar, Lei de Introdução ao Código Civil brasileiro, cit., p. 331; STRENGER, Irineu, Direito internacional privado, cit., p. 431; e BASSO, Maristela. Curso de direito internacional privado, cit., p. 178.

${ }^{374}$ TJRS - AC n. 0296120-29.2014.8.21.7000. Curiosamente, o relator Umberto Guaspari Sudbrack faz expressa menção à prática de forum shopping por parte do autor, que teria à sua disposição tanto a jurisdição uruguaia quanto a brasileira:"Faculdade do autor de escolher o foro de propositura da ação indenizatória, no exercício do 'forum shopping', direito potestativo de escolha estratégica, pelas partes, do foro da sua preferência, entre os distintos foros potencialmente disponíveis ao ajuizamento da sua demanda. Conduta lícita ao autor, mormente ante a não-aplicação, no Direito brasileiro, da doutrina do 'forum non conveniens'. Impossibilidade de avaliação, por esta Corte, da eventual adequação e pertinência da escolha do autor, quanto à jurisdição para o caso." 
O quarto elemento de conexão refere-se ao direito das sucessões, que deve obedecer à lei do país em que era domiciliado o falecido (ou desaparecido), não importando a natureza e a situação dos bens, nos termos do artigo 10 da LINDB. O parágrafo $1^{\mathrm{o}}$ ainda determina que, na hipótese de sucessão de bens de estrangeiros no Brasil, será aplicada a lei brasileira em benefício do cônjuge ou dos filhos brasileiros, ou de quem os represente, sempre que não lhes seja mais favorável a lei pessoal do falecido. Esse tratamento privilegiado aos brasileiros mereceu críticas da doutrina, na medida que manifestamente cria uma situação de privilégio patrimonial aos nacionais. ${ }^{375}$

Em um caso de sucessão de um italiano, cujo último domicílio se situava na Itália, o Tribunal de Justiça de Santa Catarina, em 2009, aplicou o parágrafo $1^{\circ}$ do artigo 10 da LINDB em favor da companheira brasileira do falecido, deixando de aplicar a lei sucessória italiana, invocada pelos filhos herdeiros, mais favorável a eles. Pela lei sucessória nacional, a cônjuge brasileira participaria da herança; pela lei italiana, não. ${ }^{376}$

Por fim, o quinto elemento de conexão refere-se ao lugar da constituição das sociedades e fundações, para apuração do direito aplicável. Essa regra está presente no artigo 11 da LINDB, que endereça as questões relacionadas à determinação da lei aplicável à constituição, funcionamento (administração e gerência) e extinção da pessoa jurídica à lei do local da constituição da pessoa jurídica (lex societatis). ${ }^{377}$

O Tribunal de Justiça de São Paulo, em 2011, manteve a extinção de uma ação de execução de notas promissórias internacionais proposta por uma filial do Banco Português, localizada nas ilhas Cayman. Segundo o Tribunal, que apontou irregularidade na representação processual do exequente, o artigo 11 da LINDB determina que a lei portuguesa deve reger a constituição e o funcionamento da sociedade sediada em Portugal. Porém, como as filiais de sociedades portuguesas não detêm personalidade jurídica, não poderiam elas ser detentoras de crédito, e sim a matriz do banco. Como não houve

\footnotetext{
375 VALLADÃO, Haroldo. Unidade ou pluralidade da sucessão e do inventário e partilha no direito internacional privado. Revista dos Tribunais, v. 93, n. 830, p. 719, dez. 2004.

${ }^{376}$ TJSC - AI n. 2009.016250-3.

${ }^{377}$ RODAS, João Grandino. Sociedade comercial e Estado. São Paulo: Editora UNESP, 1995. p. 269. Para o reconhecimento da pessoa jurídica de direito estrangeiro nos Estados, diversas legislações têm preferido eleger a lei do local onde se dão as atividades da empresa, e não o local de sua constituição, como é o caso da Convenção de Haia relativa ao reconhecimento jurídico das companhias, associações e instituições internacionais, de $1^{\circ}$ de junho de 1956. A IV CIDIP, de 25 de maio de 1984, estabelece que a pessoa jurídica deve ser qualificada de acordo com a lei do local de sua constituição.
} 
comprovação de que o crédito fosse da matriz, nem que a filial detivesse personalidade jurídica, a ação foi julgada extinta. ${ }^{378}$

\subsubsection{Segundo nível de forum shopping: escolha da jurisdição e do direito aplicável pela vontade das partes}

Como já mencionado anteriormente, até o advento do NCPC, o STJ não se posicionou em definitivo quanto à validade da escolha da jurisdição pelas partes. Do mesmo modo, ainda há na doutrina brasileira severas restrições à escolha pelas partes da lei aplicável ao litígio.

Porém, como também já dito, essa situação adversa ao princípio da autonomia da vontade não impediu no Brasil a promulgação da Lei de Arbitragem (Lei n. 9.307/96), que tratou do instituto em caráter geral e da arbitragem internacional em particular, bem como a ratificação da Convenção de Nova York, em 2002 (Decreto n. 4.311/2002).

Em linhas gerais, as partes se antecipam ao litígio, firmando um contrato pelo qual estabelecem as premissas para resolução das controvérsias pela convenção arbitral. ${ }^{379}$

A essência do compromisso arbitral é a autonomia da vontade das partes, que deve prevalecer pela aplicação do pacta sunt servanda ${ }^{380}$, do consensualismo e da boa-fé.

De fato, a arbitragem adquire um aspecto jurisdicional pois, após constituídos, os árbitros se comportam como titulares de jurisdição, na medida que as partes lhe submeteram o litígio, atuando como juízes, como se estivessem num tribunal estatal. ${ }^{381}$

\footnotetext{
378 TJSP - AC n. 9153751-83.2002.8.26.0000.

379 ARAÚJO, Nadia. A nova lei de arbitragem brasileira e os "princípios uniformes dos contratos comerciais internacionais", elaborados pela UNIDROIT. In: CASELLA, Paulo Borba (Coord.). Arbitragem: lei brasileira e praxe internacional. 2. ed. rev. e aum. São Paulo: LTr, 1999. p. 134.

${ }^{380}$ Como bem dito por Carlos Alberto Carmona, a parte que se obrigou a resolver as controvérsias eventuais e futuras por arbitragem "não pode simplesmente mudar de ideia, sendo clara a intenção do legislador, portanto, no sentido de tornar realmente eficaz esta manifestação de vontade que, sob o império das leis processuais de 1939 e de 1973, anda negligenciada" (CARMONA, Carlos Alberto. Arbitragem e processo: um comentário à Lei n. 9.307/96. São Paulo: Atlas, 2004. p. 180).

${ }^{381}$ STRENGER, Irineu. Arbitragem comercial internacional. São Paulo: LTr, 1996. p. 143.
} 
De uma forma geral, tem-se a impressão de que a arbitragem pode ser a solução para os graves problemas da Justiça estatal, dentre os quais poderia se incluir o forum shopping abusivo ${ }^{382}$. Porém, nem sempre a arbitragem pode ser considerada uma solução para todos os males. ${ }^{383}$

O primeiro obstáculo relaciona-se com o consenso sobre a própria arbitragem. No dizer de Nadia de Araujo, esse é um tema caro ao STJ, "pois a manifestação da vontade das partes em escolher a arbitragem, e com isso demonstrar sua renuncia à possibilidade de usar o aparato estatal" precisa estar comprovada de forma inquestionável ${ }^{384}$. Qualquer dúvida a esse respeito pode levar a um forum shopping reverso, com a propositura de medidas judiciais pela parte objetivando desconstituir o compromisso arbitral.

O eventual conflito de qualificações na matéria posta à arbitragem pode igualmente levar à alegação de que esse procedimento não se presta ao propósito pretendido, justamente pelo fato de que a matéria não seria passível de resolução pela via arbitral. Algumas jurisdições não permitem que certas matérias possam ser discutidas por arbitragem, como insolvência, direito antitruste, propriedade intelectual ou direitos reais, o que levaria, dentre outros efeitos, à ocorrência de procedimentos paralelos (arbitragem e a via judicial estatal). ${ }^{385}$

$\mathrm{Na}$ ausência de regras universais que regulem a competência internacional, é plenamente factível a ocorrência de procedimentos paralelos em diversas jurisdições, muitas vezes opostos. No caso brasileiro, a própria redação do artigo 90 do CPC de 1973 e do artigo 24 do NCPC permitem essa ocorrência, ao expressamente afastar os efeitos da litispendência internacional. Esse assunto será retomado oportunamente.

\footnotetext{
382 BORCHERS, Patrick J. The internationalization of contractual conflicts law. Vanderbilt Journal of Transnational Law, v. 28, p. 423, 1995.

383 "The vaunted advantages of arbitration are not guaranteed. Although arbitration can often be superior, as an empirical matter it is not clear that binding arbitration is necessarily faster, cheaper, and otherwise better than litigation." (STERNLIGHT, Jean R. Panacea or corporate tool? Debunking the Supreme Court's preference for binding arbitration. Washington University Law Quarterly, v. 74, p. 637, 1996.

384 ARAÚJO, Nadia. O STJ e a homologação de sentenças arbitrais estrangeiras: dez anos de atuação. In: TIBURCIO, Carmen; MENEZES, Wagner; VASCONCELOS, Raphael (Orgs.). Panorama do direito internacional privado atual e outros temas contemporâneos: festschrift ao professor Jacob Dolinger. Belo Horizonte: Arraes, 2015. p. 163.

${ }^{385}$ DE LY, Filip. Forum shopping and the determination of the place of arbitration. In: FERRARI, Franco (Ed.). Forum shopping in the international commercial arbitration context. Munich: Sellier European Law Publishers (SELP), 2013. p. 56.
} 


\subsubsection{Terceiro nível de forum shopping: coisa julgada estrangeira}

No terceiro nível de forum shopping, o demandante se vale de uma sentença transitada em julgado ${ }^{386}$, podendo dela extrair efeitos no estrangeiro.

Num primeiro momento, os efeitos da coisa julgada são limitados à jurisdição em que foi proferida. Assim dispõe o artigo 16 do NCPC: “A jurisdição civil é exercida pelos juízes e pelos tribunais em todo o território nacional, conforme as disposições deste Código".

Porém, é possível, factível e cada vez mais comum que sentenças originadas em um Estado sejam reconhecidas por outros, como se nacionais o fossem. Para isso, basta que o Estado de destino reconheça, por meio de critérios próprios de homologação, a eficácia da sentença (rectius: coisa julgada) estrangeira ${ }^{387}$. Os requisitos para homologação da sentença estrangeira estão definidos na Resolução n. 9, de 4 de maio de 2005, do STJ e, a partir de 17 de março de 2016, no artigo 963 do NCPC.

Uma vez homologada, a sentença estrangeira estenderá ao território do foro a mesma imutabilidade que detinha no Estado de origem, podendo ser executada como se fosse uma sentença nacional, tal qual prevista no artigo 515, VIII, do NCPC.

E essa homologação ocorrerá no Brasil ainda que esteja pendente ação idêntica, posto que o artigo 24 do NCPC afasta os efeitos da litispendência internacional. Concedido o exequatur pelo STJ, a ação proposta no país deverá ser extinta ${ }^{388}$, por força da coisa julgada.

\footnotetext{
${ }^{386}$ Segundo Barbosa Moreira, a coisa julgada é uma característica da sentença, consistente na imutabilidade de seu conteúdo (MOREIRA, José Carlos Barbosa. O novo processo civil brasileiro. Rio de Janeiro: Forense, 1998, p. 88). Dinamarco entende que a coisa julgada é um atributo específico dos efeitos da sentença, ou seja, a impossibilidade de modificação, que se agrega aos reflexos que ela produz, estabilizando-os. Seria a própria imutabilidade dos efeitos da sentença (DINAMARCO, Cândido Rangel, Instituições de direito processual civil, cit., v. 1, p. 302).

387 "Reconhecer uma sentença estrangeira é atribuir-lhe no Estado do foro (Estado requerido, Estado ad quem) os efeitos que lhe competem segundo a lei do Estado onde foi proferida (Estado de origem, Estado $a$ quo), ou pelo menos alguns desses efeitos." (CORREIA, António de Arruda Ferrer, Lições de direito internacional privado, cit., v. 1, p. 454).

388 JATAHY, Vera Maria Barrera, Do conflito de jurisdições: a competência internacional da justiça brasileira, cit., p. 149.
} 
Nesse caso, se antevê o uso do forum shopping de terceiro nível, que é a busca da coisa julgada estrangeira como forma de se extinguir uma eventual ação proposta no foro local. Para isso, deve haver competência concorrente entre duas ou mais jurisdições e é necessário que entre elas não existam consequências pela ocorrência dos procedimentos paralelos (como a litispendência internacional). ${ }^{389}$

O forum shopping de terceiro nível, portanto, serve de anteparo pelo litigante, que pode ou não se servir dos efeitos da coisa julgada estrangeira, com o propósito de extinguir outra demanda que esteja tramitando no Brasil.

No REsp n. 1.203.430-PR, o STJ manteve a extinção de uma ação de cobrança cumulada com pedido de indenização ajuizada por uma sociedade brasileira exportadora, em face de uma sociedade italiana, pelo fato desta última ter obtido a homologação de uma sentença arbitral estrangeira, movida entre as mesmas partes, que por sua vez afastou a responsabilidade da sociedade italiana.

Já na MC n. 15.398/RJ, o STJ extinguiu uma ação cautelar inominada preparatória de recurso especial, interposto contra a extinção de uma ação de indenização movida por uma empresa de engenharia em face da Petrobras, sob o argumento de que a mesma ação já havia sido proposta entre as mesmas partes na Inglaterra, com resultado desfavorável à empresa de engenharia. Assim, muito embora a sentença inglesa de improcedência ainda não tivesse sido homologada pelo STJ, a propositura da mesma ação proposta na Inglaterra em tribunais brasileiros configurava um ato de violação à boa-fé objetiva, segundo entendeu o STJ.

Em outro caso de grandes proporções, um grupo de indígenas equatorianos da província de Sucumbíos propôs uma ação coletiva ambiental em face da Texaco Inc., por suposta contaminação de parte de seu território, localizado na Amazônia equatoriana. A contaminação teria sido causada entre os anos de 1964 e 1990 pela empresa Texaco, posteriormente adquirida pela Chevron Corporation, sediada nos Estados Unidos. A ação

\footnotetext{
${ }^{389}$ Barbosa Moreira, cuja opinião balizou a jurisprudência do STF desde os anos 70, mostrou que a sentença que primeiro se tornar eficaz, com trânsito em julgado, é aquela que prevalecerá: a nacional, pelo comando expedido pelo juiz competente, ou a estrangeira, desde que deferida a homologação pelo STJ (MOREIRA, José Carlos Barbosa. Relações entre processos instaurados sobre a mesma lide civil, no Brasil e em país estrangeiro. In: ESTUDOS Jurídicos em homenagem ao professor Oscar Tenório. Rio de Janeiro: Universidade do Estado do Rio de Janeiro (UERJ), 1977. p. 365).
} 
foi originariamente proposta em 1993 nos Estados Unidos, na corte federal de Nova York, sendo o feito extinto em 2002, com base na doutrina do forum non conveniens ${ }^{390}$. A ação foi reproposta em 2003 no Equador e a Chevron Corporation - sucessora da Texaco - foi condenada em 2012 ao pagamento de US\$ 9,5 bilhões em favor dos indígenas pela Corte Nacional de Justiça do Equador ${ }^{391}$. Em 2013, com o trânsito em julgado da sentença, e tendo a Chevron encerrado suas atividades no Equador, os indígenas promoveram pedidos de homologação de sentença estrangeira na Argentina, no Canadá e no Brasil ${ }^{392}$. Enquanto isso, a Chevron propôs em 2009 um procedimento perante o Tribunal Permanente de Arbitragem (TPA) na Haia, em face do governo do Equador, acusando o Judiciário do país de ter permitido fraudes processuais na ação movida contra a Chevron, o que violaria o Tratado de Incentivo e Proteção Recíproca de Investimentos, firmado entre os Estados Unidos e o Equador em 27.08.1993 $3^{393}$. O caso continua em aberto, não tendo havido até o momento a homologação da sentença equatoriana nas jurisdições do Brasil, Argentina ou Canadá. Do mesmo modo, ainda não houve o julgamento da arbitragem instaurada na Haia.

Nesse caso Aguinda v. Texaco, a utilização do forum shopping de terceiro nível pelos indígenas, que é a homologação da sentença equatoriana na Argentina, Canadá e Brasil (e posterior execução), poderá ser barrada pela eventual homologação de uma decisão favorável no procedimento instaurado pela Chevron perante a Corte Permanente de Arbitragem, nas mesmas jurisdições ${ }^{394}$, o que também não deixa de ser outro forum shopping de terceiro nível, porém reverso.

\subsubsection{Efeitos do forum shopping internacional}

De um modo geral, o artigo 24 do NCPC afasta qualquer efeito do forum shopping internacional, até que se apresente a sentença estrangeira no STJ e ocorra a efetiva homologação. Essa regra decorre do princípio da plenitudo jurisdictionis, fazendo com que a jurisdição do foro prevaleça sobre a estrangeira. Diz o citado artigo 24 que "a ação

\footnotetext{
${ }^{390}$ Caso Aguinda v. Texaco, Inc., No. 93 Civ. 7527, 1994 WL 142006.

${ }^{391}$ Caso María Aguinda Salar y otros contra Chevron Corporation, juicio n. 174-2012.

392 SEC n. 8542-EC.

${ }^{393}$ PCA Case n. 209-23.

394 GÓMEZ, Manuel A. The global chase: seeking the recognition and enforcement of the Lago Agrio judgment outside of Ecuador. Stanford Journal of Complex Litigation, v. 1, No. 2, p. 440, Spring 2013.
} 
proposta perante tribunal estrangeiro não induz litispendência e não obsta que a autoridade judiciária brasileira conheça da mesma causa e das que lhe são conexas, ressalvadas as disposições em contrário de tratados internacionais e acordos bilaterais em vigor no Brasil".

Como bem observou Barbosa Moreira quanto à redação do artigo 90 do CPC de 1973, que é muito próximo do artigo 24 do NCPC, além de nacionalista, o dispositivo não observou o rigor técnico, na medida que a litispendência internacional poderá ocorrer, embora não possa ser invocada como matéria de defesa processual. ${ }^{395}$

Interessante notar que já em 1928 o Código Bustamante procurou evitar os efeitos da litispendência internacional, em seu artigo 394: “A litispendência, por motivo de pleito em outro Estado contratante, poderá ser alegada em matéria cível, quando a sentença proferida em um deles deva produzir no outro os efeitos de coisa julgada."

O Código de Processo Civil de 1939 não tratou do tema da competência internacional, de forma que Haroldo Valladão defendeu que o direito brasileiro reconhecia tais efeitos. ${ }^{396}$

Não sem razão, o advento do CPC de 1973 e seu artigo 90 causou consternação na doutrina, como aponta Umberto Celli ${ }^{397}$. Foram favoráveis ao novo modelo Arruda Alvim $^{398}$ e Celso Agrícola Barbi ${ }^{399}$, ao entenderem que, nas hipóteses de competência concorrente, as cortes brasileiras não poderiam ser impedidas de julgar os respectivos litígios.

O novo Código de Processo Civil de 2015, em seu artigo 24, praticamente repetiu a redação do artigo 90 do CPC de 1973, acrescendo haver exceção, e portanto

\footnotetext{
${ }^{395}$ MOREIRA, José Carlos Barbosa, Relações entre processos instaurados sobre a mesma lide civil, no Brasil e em país estrangeiro, in ESTUDOS jurídicos em homenagem ao professor Oscar Tenório, cit., p. 365.

${ }^{396}$ VALLADÃO, Haroldo, Direito internacional privado, cit., v. 1, p. 185.

${ }^{397}$ CELLI JUNIOR, Umberto. Litispendência internacional no Brasil e no Mercosul. Revista Brasileira de Direito Processual, v. 19, n. 76, p. 227, out./dez. 2011.

${ }^{398}$ ARRUDA ALVIM, José Manuel de. Ensaio sobre a litispendência no direito processual civil. São Paulo: Revista dos Tribunais, 1970. v. 2, p. 412.

399 BARBI, Celso Agrícola, Comentários ao Código de Processo Civil: Lei n. 5.869, de 11 de janeiro de 1973: arts. $1^{\circ}$ a 153, cit., v. 1, p. 404.
} 
reconhecimento da litispendência internacional, na hipótese de acordos internacionais, como é o caso do Tratado de Las Leñas, em seu artigo 22, segunda parte.

Não obstante a posição brasileira quanto à litispendência internacional, os movimentos de integração internacionais, tais como a União Europeia e o Mercosul, acabaram por reconhecer a regra já apontada há quase noventa anos pelo Código Bustamante, assim como pelos países do common law, por intermédio da doutrina do forum non conveniens.

O artigo 24 do NCPC afasta também a possibilidade de a conexão ser um critério a ser utilizado como parâmetro de fixação da competência da Justiça brasileira.

O STJ, no REsp 2.170-SP, confirmou esse entendimento, embora exista certa divergência na doutrina sobre o tema. Nesse caso específico, o autor Naji Robert Nahas propôs uma ação de nulidade de contrato cumulada com pedido de indenização, em face do Banque Populaire Suisse e da Advicorp Advisory Financial Corp., instituições financeiras sediadas no estrangeiro. O pedido indenizatório se fundou no fato de que essas instituições propuseram uma ação cautelar de protesto contra alienação de bens em face de Naji Nahas, no Brasil, o que teria abalado sua imagem. Este último, em sua ação indenizatória, alegou que a propositura da ação cautelar teria gerado danos à sua imagem no Brasil, o que justificava seu pedido de indenização. Naji Nahas aproveitou o ensejo e cumulou a ação indenizatória com uma ação declaratória de nulidade do contrato internacional de financiamento, firmado com ambas as instituições, baseado na existência de conexão entre os pedidos (indenizatório e declaratório). As instituições financeiras requereram a extinção do feito declaratório, sob o argumento da incompetência da Justiça brasileira para julgar essa demanda, tendo em vista que o contrato fora firmado no exterior. Essa alegação foi aceita em primeira instância, havendo a extinção parcial do feito, e depois reformada pelo TJSP, que aceitou o argumento de conexão entre os pedidos. As instituições financeiras apresentaram recurso especial ao STJ. Esse tribunal afastou a possibilidade de se reconhecer a conexão entre demandas como um critério definidor da competência internacional da Justiça brasileira. O relator do recurso no STJ, ministro Pádua Ribeiro, assim resumiu as divergências na doutrina e, ao final, concluiu pela tese contrária ao reconhecimento da competência internacional dos tribunais brasileiros baseada na conexão: 


\begin{abstract}
Cumpre examinar se merece acolhida o entendimento do acórdão, fundado na conexão. O tema é objeto de controvérsia. A tese do julgado recorrido é placitada por Tornaghi que afirma sem ter reputado necessário maiores considerações (Comentários ao CPC, vol. I - p. $3101^{\text {a }}$ ed.). No mesmo sentido, Ada Pelegrini, em parecer juntado aos autos, onde se salienta que, se admitida a eleição de foro, com maior razão a modificação da competência pela conexão.

Parece mais acertada, entretanto, a doutrina contrária, sustentada por José Ignácio Botelho de Mesquita (Rev. de Processo - vol. 50, p. 61). Após salientar que o direito brasileiro, ao contrário do italiano, não elegeu a conexão como critério para fixação da competência internacional, invoca o disposto no artigo 90 do CPC, considerando que este cortou cerne a discussão:

"A pendencia de uma ação no exterior não impede que a Justiça brasileira conheça de ações conexas com a proposta no exterior (art. 90) e simetricamente a conexão com uma ação proposta no Brasil não se inclui entre os pontos de contato suficientes para estender até ela a jurisdição nacional (art. 88)".

E a solução parece efetivamente a melhor. Admitir-se que a conexão possa levar a que se firme a competência da autoridade judiciária brasileira, para hipóteses não cogitadas nos artigos 88 e 89 do CPC, poderá levar a um alargamento excessivo daquela, colocando em risco o princípio da efetividade que domina a matéria.
\end{abstract}

Muito embora a litispendência e a conexão internacionais não tenham no NCPC nem de longe - os efeitos preconizados pelo Código Bustamante ou pelo Regime de Bruxelas-Lugano, é certo que a existência de demandas no exterior traz consequências importantes ao direito brasileiro. Tanto a litispendência quanto a conexão internacionais não produzem os efeitos processuais de prevenir o juízo, perpetuar a competência, estabilizar a demanda ou suspender outros processos em caso de prejudicialidade (art. 24 do NCPC). Porém a citação válida, ainda quando oriunda ou realizada no estrangeiro, produz os efeitos de constituir o devedor em mora, interromper a prescrição ou tornar a coisa litigiosa. $^{400}$

No âmbito do Mercosul, o Brasil vinculou-se a diversas convenções regionais, visando a regular situações processuais de interesse comum, que por seu turno alteraram disposições internas sobre conexão e litispendência internacionais, eleição de foro e eleição de jurisdição, como será tratado a seguir.

\title{
3.4.2.1 Conexão e litispendência internacional: o Protocolo de Las Leñas
}

O Protocolo de Cooperação e Assistência Jurisdicional em Matéria Civil, Comercial, Trabalhista e Administrativa, conhecido como Protocolo de Las Leñas, foi promulgado no Brasil pelo Decreto n. 2.067, de 1996. Esse Protocolo é um importante

${ }^{400}$ DINAMARCO, Cândido Rangel, Instituições de direito processual civil, cit., v. 1, p. 371. 
instrumento normativo do processo de integração regional, pois contribuiu para o tratamento equitativo dos cidadãos do Mercosul e seus residentes permanentes, ao facilitar o livre acesso à jurisdição de qualquer dos Estados membros e regular justamente a ocorrência da litispendência e da conexão internacional. ${ }^{401}$

Esse direito está previsto no artigo 22, segunda parte, do Protocolo de Las Leñas:

\begin{abstract}
Artigo 22
Quando se tratar de uma sentença ou de um laudo arbitral entre as mesmas partes, fundamentado nos mesmos fatos, e que tenha o mesmo objeto de outro processo judicial ou arbitral no Estado requerido, seu reconhecimento e sua executoriedade dependerão de que a decisão não seja incompatível com outro pronunciamento anterior ou simultâneo proferido no Estado requerido.

Do mesmo modo não se reconhecerá nem se procederá à execução, quando se houver iniciado um procedimento entre as mesmas partes, fundamentado nos mesmos fatos e sobre o mesmo objeto, perante qualquer autoridade jurisdicional da Parte requerida, anteriormente à apresentação da demanda perante a autoridade jurisdicional que teria pronunciado a decisão da qual haja solicitação de reconhecimento.
\end{abstract}

Com uma redação possivelmente mais próxima dos meios diplomáticos do que da prática jurídica, a primeira parte do artigo 22 reconhece os efeitos da coisa julgada internacional, sem necessidade prévia do procedimento de homologação no STJ, desde que a sentença estrangeira reúna as condições previstas no artigo 20 do citado Protocolo. ${ }^{402}$

A redação da segunda parte do artigo 22 merece um cuidado mais aprofundado. Quando o artigo afirma que "não se reconhecerá nem se procederá à execução" de um segundo processo movido "entre as mesmas partes, fundamentado nos mesmos fatos e sobre o mesmo objeto", a doutrina brasileira diverge sobre o significado da expressão "não se reconhecerá".

401 CELLI JUNIOR, Umberto, Litispendência internacional no Brasil e no Mercosul, cit., p. 231; MAGALHÃES, José Carlos de. O protocolo de Las Leñas e a eficácia extraterritorial das sentenças e laudos arbitrais proferidos nos países do Mercosul. Revista de Informação Legislativa, Brasília, DF, v. 36, n. 144 , p. 282, out./dez. 1999.

402 “Artigo 20. As sentenças e os laudos arbitrais a que se refere o artigo anterior terão eficácia extraterritorial nos Estados Partes quando reunirem as seguintes condições: a) que venham revestidos das formalidades externas necessárias para que sejam considerados autênticos no Estado de origem; b) que estejam, assim como os documentos anexos necessários, devidamente traduzidos para o idioma oficial do Estado em que se solicita seu reconhecimento e execução; c) que emanem de um órgão jurisdicional ou arbitral competente, segundo as normas do Estado requerido sobre jurisdição internacional; d) que a parte contra a qual se pretende executar a decisão tenha sido devidamente citada e tenha garantido o exercício de seu direito de defesa; e) que a decisão tenha força de coisa julgada e/ou executória no Estado em que foi ditada; f) que claramente não contrariem os princípios de ordem pública do Estado em que se solicita seu reconhecimento e/ou execução. Os requisitos das alíneas (a), (c), (d), (e) e (f) devem estar contidos na cópia autêntica da sentença ou do laudo arbitral." 
Umberto Celli Junior entende que o "reconhecimento" mencionado pelo dispositivo refere-se ao conhecimento do feito, como um pressuposto processual de validade. Ocorrendo a litispendência internacional no âmbito do Mercosul, entende Celli que o segundo feito deveria ser julgado extinto. ${ }^{403}$

Por outro lado, Leonardo Grecco entende que o termo "reconhecimento" esteja relacionado à eficácia da sentença estrangeira fora da jurisdição em que foi proferida. Assim, ocorrendo a litispendência internacional no âmbito do Mercosul, defende Greco que o segundo feito não seja extinto, mas que sua futura sentença não seja passível de ser executada fora do território do país em que vier a ser proferida. ${ }^{404}$

A primeira posição parece ser mais acertada. Em primeiro lugar, pelo princípio da integração, não parece fazer sentido que um protocolo voltado à cooperação entre Estados defina a ocorrência de uma situação processual de conflito de jurisdições (tal qual a litispendência internacional) e dessa definição não decorra uma consequência sistemicamente coerente, tal qual a extinção do feito proposto a posteriori. Em segundo lugar, a segunda parte do artigo 22 diz claramente que "nem se procederá à execução", sem ressalvar a eficácia executiva da sentença ou laudo arbitral dentro do território original em que tiverem sido proferidos, fazendo parecer que eventual coisa julgada seria considerada ineficaz.

Outra questão, que aparentemente não foi ainda abordada pela doutrina, é saber se o citado artigo 22 do Protocolo de Las Leñas faz referência exclusivamente à litispendência internacional, ou se as consequências se estenderiam à conexão internacional, criando-se um novo método de definição da competência internacional no âmbito do Mercosul.

Levando-se em conta que a redação do Protocolo de Las Leñas parece ser mais afeita aos meios diplomáticos, conforme referido acima, o que inclusive já permitiu interpretações díspares sobre o significado do termo "reconhecimento", é possível que a expressão "um procedimento [tiver sido iniciado] entre as mesmas partes, fundamentado nos mesmos fatos e sobre o mesmo objeto" possa ter um alcance mais elástico, e inclua as

\footnotetext{
${ }^{403}$ CELLI JUNIOR, Umberto, Litispendência internacional no Brasil e no Mercosul, cit., p. 233.
}

${ }^{404}$ GRECO, Leonardo, A competência internacional da justiça brasileira, cit., p. 189. 
hipóteses de conexão e continência entre demandas propostas concomitantemente nos Estados partes do Mercosul.

Se o escopo desse Protocolo, no dizer de Umberto Celli, é "contribuir para o tratamento equitativo" dos cidadãos do Mercosul, "facilitando-lhes o livre acesso à jurisdição de qualquer dos Estados membros para a defesa de seus direitos e interesses"405, parece claro que essa defesa passa pela segurança jurídica ${ }^{406}$ dos jurisdicionados, sendo que os casos de conexão causam tanta insegurança quanto a litispendência. A conexão internacional também permite o mesmo risco de contradição, merecendo ser regulada da mesma forma, com a mesma intensidade. Excluir a aplicação do artigo 22 à causas conexas parece alijar os jurisdicionados da proteção quanto à ocorrência de ações inúteis, sobrepostas ou paralelas. A existência de decisões conflitantes em litígios que tratem de situações semelhantes é, naturalmente, motivo de descrédito e causa de insegurança jurídica $^{407}$, justamente o que se pretendeu evitar com o Protocolo.

Em terceiro lugar, litispendência, continência e conexão, além de dizerem respeito aos pressupostos processuais de validade, no dizer de Liebman, indicam igualmente a qual juiz (ou, no caso, qual jurisdição) cabe decidir uma causa no caso concreto ${ }^{408}$. Não faz sentido se regular um fenômeno - no caso, a litispendência - e ignorar os demais, criandose uma situação jurídica parcialmente regulada (e, portanto, podendo ser suprida por analogia).

À primeira vista, muito embora pareça não haver um estudo aprofundado a esse respeito, parece factível a inclusão dos fenômenos da conexão e da continência internacionais como passíveis de aplicação do artigo 22 do Protocolo de Las Leñas, cuja consequência seria a extinção do feito proposto em segundo lugar.

\footnotetext{
${ }^{405}$ CELLI JUNIOR, Umberto, Litispendência internacional no Brasil e no Mercosul, cit., p. 231.

406 "A segurança e a proteç̧ão da confiança exigem, no fundo: (1) confiabilidade, clareza, racionalidade e transparência dos atos do poder; (2) de forma que em relação a eles o cidadão veja garantida a segurança nas suas disposições pessoais e nos efeitos jurídicos dos seus próprios actos. Deduz-se já que os postulados da segurança e da protecção da confiança são exigíveis perante qualquer acto de qualquer poder legislativo, executivo e judicial." (CANOTILHO, José Joaquim Gomes, Direito constitucional e teoria da constituição, cit., p. 257).

${ }^{407}$ THEODORO JÚNIOR, Humberto. Curso de direito processual civil. Rio de Janeiro: Forense, 2005. v. 1, p. 168-169.

${ }^{408}$ LIEBMAN, Enrico Tullio, Manual de direito processual civil, cit., v. 1, p. 76.
} 
Essa conclusão parece estar mais em harmonia com os propósitos de salvaguarda do Protocolo ${ }^{409}$, e em sintonia tanto com o antigo Código Bustamante ${ }^{410}$ quanto com o Regime de Bruxelas-Lugano. ${ }^{411}$

Porém, por outro lado, há que se fazer uma ressalva negativa a essa inovação.

Tanto a compreensão estrita do citado artigo 22 (que restringe sua aplicação à litispendência internacional), como a compreensão ampliada (que entende sua incidência às hipóteses de conexão e continência internacionais), embora signifiquem em qualquer hipótese um avanço ${ }^{412}$ em relação ao artigo 24 do NCPC brasileiro, permitem por outro lado a ocorrência de forum shopping abusivo reverso no âmbito do Mercosul, na modalidade denominada pela doutrina europeia como "torpedo", como será demonstrado oportunamente.

\subsubsection{A prevenção de foro internacional: Protocolo de Ouro Preto}

O Protocolo de Medidas Cautelares do Mercosul, aprovado em Ouro Preto em 1994, e promulgado no Brasil pelo Decreto n. 2.626, de 15 de junho de 1998, previu uma via simplificada no cumprimento de cartas rogatórias, como dispõe seu artigo 18. Esse Protocolo previu a cooperação entre as autoridades dos Estados membros, por meio de medidas de urgência, dispensando a tramitação por via diplomática e o procedimento da

\footnotetext{
409 Haja vista pretender "contribuir para o tratamento equitativo dos cidadãos do MERCOSUL e seus residentes permanentes, ao facilitar o livre acesso à jurisdição de qualquer dos Estados-Membros”, como consta do preâmbulo do Protocolo de Las Leñas.

410 “Art. 391. Aquelle que recebe a carta ou commissão rogatoria se deve sujeitar, quanto ao seu objecto, á lei do deprecante e, quanto á forma de a cumprir, á sua propria lei. Pode se entender, portanto, que os efeitos da demanda internacional apenas gerará efeitos ao réu quando efetivamente receber a carta rogatória, e não antes."

411 “Art. 29, 1. Sem prejuízo do disposto no artigo 31, n. 2, quando ações com a mesma causa de pedir e entre as mesmas partes forem submetidas à apreciação de tribunais de diferentes Estados-Membros, qualquer tribunal que não seja o tribunal demandado em primeiro lugar deve suspender oficiosamente a instância até que seja estabelecida a competência do tribunal demandado em primeiro lugar."

${ }^{412}$ CELLI JUNIOR, Umberto, Litispendência internacional no Brasil e no Mercosul, cit., p. 231; LOULA, Maria Rosa Guimarães. A extraterritorialidade das sentenças no Protocolo de Las Leñas sobre cooperação e assistência jurisdicional em matéria civil, comercial, trabalhista e administrativa. In: TIBURCIO, Carmen; BARROSO, Luís Roberto (Orgs.). O direito internacional contemporâneo: estudos em homenagem ao professor Jacob Dolinger. Rio de Janeiro: Renovar, 2006. p. 656; UBALDO, Edson Nelson. O Protocolo de Las Leñas: vantagens - problemas - sugestões. In: IRIGOIN BARRENE, Jeannette (Coord.). Chile y el Mercosur en América Latina: VI Encuentro Internacional de Derecho de América del Sur. Santiago: Editorial Juridica de Chile, 1999. v. 1, p. 391.
} 
homologação da sentença estrangeira entre os juízes das zonas de fronteira, conforme o artigo 19.

Indiscutivelmente, as medidas cautelares desempenham um papel de grande importância dentro no âmbito processual ${ }^{413}$, pois servem para garantir não só o cumprimento de eventual condenação num processo, mas também para assegurar o principal objeto da prestação jurisdicial ou arbitral que se propôs.

A interpretação do Protocolo de Ouro Preto é influenciada diretamente por outra norma do Mercosul, o Protocolo de Las Leñas, que, como tratado anteriormente, cuida, no artigo 22, in fine, da hipótese de litispendência (interpretação estrita) e conexão (interpretação ampliada).

$\mathrm{Na}$ medida que o Protocolo de Las Leñas veda o "reconhecimento" de ações e a "execução" de sentenças "quando se houver iniciado um procedimento entre as mesmas partes", e o Protocolo de Ouro Preto cria um fast track para o cumprimento de medidas cautelares, é bem factível que se dê a prevenção do foro internacional pela propositura acelerada de uma ação cautelar num Estado escolhido pelo forum shopper mercosulino.

O Protocolo de Las Leñas elegeu o critério cronológico para aferição da competência de ações litispendentes (ou conexas, pela interpretação ampliada do artigo 22, in fine), no sentido de privilegiar a demanda que tiver sido iniciada em primeiro lugar. Porém, não definiu o dispositivo quando é que uma ação se iniciou.

No caso do sistema Bruxelas-Lugano, o artigo 32, 1, “a e b", do Regulamento (UE) 1.215/2012 elege o critério da distribuição do feito como o definidor do momento em que a ação foi proposta ou distribuída ${ }^{414}$. Esse mesmo critério foi adotado pelo legislador brasileiro, no artigo 59 do NCPC.

\footnotetext{
413 "Ela [atividade cautelar] se dirige a assegurar, a garantir o eficaz desenvolvimento e o resultado profícuo das outras duas, e concorre por isso de forma mediata ao bom sucesso do escopo geral da jurisdição." (LIEBMAN, Enrico Tullio, Manual de direito processual civil, cit., v. 1, p. 187).

414 "Artigo 32. 1. Para efeitos da presente secção, considera-se que a ação foi submetida à apreciação do tribunal: a) No momento em que for apresentado ao tribunal o documento que dá início à instância, ou documento equivalente, desde que o requerente tenha tomado posteriormente as medidas que lhe incumbem para que o requerido seja citado; ou b) Se o documento tiver de ser notificado antes de ser apresentado ao tribunal, no momento em que for recebido pela autoridade responsável pela notificação, desde que o requerente tenha tomado posteriormente as medidas que lhe incumbem para que o documento seja junto ao processo."
} 
$\mathrm{Na}$ falta de trabalhos acadêmicos ou jurisprudência a respeito, uma possível interpretação pode ser buscada no artigo $3^{\circ}$ do Protocolo de Las Leñas, que prevê que "os cidadãos e os residentes permanentes de um dos Estados partes gozarão, nas mesmas condições dos cidadãos e residentes permanentes do outro Estado parte, do livre acesso à jurisdição desse Estado para a defesa de seus direitos e interesses”.

Nesse sentido, considerando que os jurisdicionados brasileiros têm que se submeter à distribuição do feito como critério de fixação da competência territorial em hipóteses de competência concorrente (art. 59 do NCPC), pode-se concluir que todos os processos que vierem a ser propostos nos demais países do Mercosul, a partir da respectiva distribuição, prevenirão a competência para os futuros litígios conexos, afastando a competência da Justiça brasileira $^{415}$. Assim, na falta de uma melhor especialização do instituto da prevenção no âmbito do Mercosul, tal interpretação parece - ao menos, neste momento mais adequada.

\subsubsection{Forum shopping em matéria contratual: o Protocolo de Buenos Aires}

O Protocolo de Buenos Aires, firmado em 4 de maio de 1994, e que trata da jurisdição internacional em matéria contratual, vigora no Brasil desde 6 de junho de 1996, conforme o Decreto n. 2.095. É sem dúvida um importante instrumento de definiçãa da competência internacional dos países do Mercosul, que de certa forma moderniza o direito brasileiro sobre o tema, fundado em critérios soberanistas. ${ }^{416}$

O artigo $1^{\circ}$ do Protocolo de Buenos Aires define seu âmbito de aplicação aos "contratos internacionais de natureza civil ou comercial, celebrado entre particulares pessoas físicas e jurídicas", com domicílio ou sede social nos Estados partes do Mercosul (item a) ou quando pelo menos uma das partes tenha domicílio ou sede social num Estado parte e, cumulativamente, ocorram dois requisitos: (1) tenha sido celebrado um acordo de

\footnotetext{
${ }^{415}$ Segundo Moniz de Aragão, ao se referir aos efeitos da citação válida no CPC de 1973, divide-os em "natureza material e processual". A prevenção, a litispendência e a litigiosidade são consideradas efeitos processuais. Já a constituição em mora e a interrupção da prescrição são tidas como efeitos materiais (ARAGÃO, Egas Moniz de. Comentários ao Código de Processo Civil. Rio de Janeiro: Forense, 1992. v. 1, p. 245).

${ }^{416}$ CELLI JUNIOR, Umberto, Litispendência internacional no Brasil e no Mercosul, cit., p. 231.
} 
eleição de foro de um dos países do Mercosul e (2) "exista uma conexão razoável segundo as normas de jurisdição deste Protocolo" (item b) ${ }^{417}$. Em qualquer hipótese, o Protocolo se refere à "jurisdição contenciosa", afastando matérias específicas, cuja competência ficou a critério das regras de competência dos Estados partes, conforme o rol do artigo $2^{\circ}{ }^{418}$

Segundo o conceito clássico de Clóvis Beviláqua, contrato é um "acordo de vontades para o fim de adquirir, resguardar, modificar ou extinguir direitos" ${ }^{419}$. O contrato, em sentido amplo, é também definido como "todo negócio jurídico que se forma pelo concurso de vontades" (em oposição, assim, às declarações unilaterais de vontade, como a promessa de recompensa); em sentido estrito, o contrato designa "o acordo de vontades produtivo de efeitos obrigacionais na esfera patrimonial"420. O contrato opera fundamentalmente na esfera econômica, ou seja, onde há efetiva ou potencial circulação de riqueza, compreendida esta não só como dinheiro e outros bens materiais, mas também como todas as utilidades suscetíveis de avaliação econômica, ainda que não sejam coisas em sentido próprio - "nestes termos, até a promessa de fazer ou não fazer qualquer coisa em benefício de alguém, representa, para o promissário, uma riqueza verdadeira e própria". ${ }^{421}$

Por seu turno, no dizer autorizado de Irineu Strenger, contratos internacionais são "todas as manifestações bi ou plurilaterais da vontade livre das partes, objetivando relações patrimoniais ou de serviços, cujos elementos sejam vinculantes de dois ou mais sistemas jurídicos extraterritoriais, pela força do contrato, lugar da execução, ou qualquer circunstância que exprima um liame indicativo do direito aplicável", 422

417 O Protocolo não define o que seria uma "conexão razoável”, levando Ruy Rosado a afirmar que essa exigência tem como propósito evitar abusos, sem porém definir tais ocorrências, mas levando em conta o risco de fóruns exorbitantes, com o que concordamos (AGUIAR JÚNIOR, Ruy Rosado de. Protocolo de Buenos Aires sobre jurisdição internacional. Revista do Instituto dos Advogados de São Paulo, São Paulo, v. 3, n. 6, p. 193, jul./dez. 2000).

${ }^{418}$ As relações jurídicas entre os falidos e seus credores e demais procedimentos análogos, especialmente as. concordatas; a matéria tratada em acordos no âmbito do direito de família e das sucessões; os contratos de seguridade social; os contratos administrativos; os contratos de trabalho; os contratos de venda ao consumidor; os contratos de transportes; os contratos de seguro; e os direitos reais.

419 BEVILAQUA, Clovis. Codigo Civil dos Estados Unidos do Brazil commentado. Rio de Janeiro: Francisco Alves, 1934. p. 245.

${ }^{420}$ GOMES, Orlando. Contratos. 24. ed. Atualização e notas de Humberto Theodoro Júnior. Rio de Janeiro: Forense, 2001. p. 9.

${ }^{421}$ ROPPO, Enzo. O contrato. Coimbra: Almedina, 1988. p. 13.

${ }^{422}$ STRENGER, Irineu. Contratos internacionais do comércio. São Paulo: LTr, 2003. p. 93. 
De antemão, percebe-se que o Protocolo de Buenos Aires concedeu ao autor a ampla faculdade de escolha da jurisdição que irá demandar, ao prever, no artigo $7^{\circ}$, que "na ausência de acordo" (rectius: eleição de foro) poderá ele optar entre o juízo do lugar do cumprimento do contrato (item "a"), o juízo do domicílio do demandado (item "b”) ou o juízo de seu domicílio ou sede social, quando demonstrar que cumpriu sua prestação (item "c"). ${ }^{423}$

$\mathrm{O}$ artigo $8^{\circ}$ especifica os lugares em que será considerado o local de cumprimento do contrato ${ }^{424}$ para efeitos do artigo $7^{\circ}$, "a", enquanto o artigo $9^{\circ}$ define os parâmetros de domicílio ${ }^{425}$, para efeitos do artigo $7^{\circ}$, "b".

As partes poderão optar pelo juízo arbitral, cuja matéria passou a ser regulada no Brasil pela Lei n. 9.307/96, sendo que o momento da escolha da jurisdição poderá ser na celebração do contrato, durante a vigência ou mesmo após, quando já houver sido instaurada uma demanda entre as partes.

$\mathrm{O}$ artigo $5^{\circ}$, item 2, determina que a validade e os efeitos da eleição de foro serão redigidos pelo direito dos Estados partes cuja jurisdição seria a competente para apreciar a demanda, caso não tivesse havido a eleição do foro. Ruy Rosado qualifica essa regra como de "difícil compreensão",426, pois o juiz eleito teria melhores condições de analisar a eventual abusividade da cláusula, bem como seus efeitos. A crítica de Ruy Rosado parece

\footnotetext{
${ }^{423}$ Essa última hipótese foi considerada por Erik Jayme uma inovação, passível de ser estendida aos conflitos oriundos da internet (JAYME, Erik, O direito internacional privado do novo milênio: a proteção da pessoa humana face à globalização, cit., p. 142).

424 “Artigo $8^{\circ}$ 1. Para os fins do artigo 7, alínea 'a', será considerado lugar do cumprimento do contrato o Estado-Parte onde tenha sido ou deva ser cumprida a obrigação que sirva de fundamento de demanda. 2. O cumprimento da obrigação reclamada será: a) nos contratos sobre coisas certas e individualizadas, o lugar onde elas existiam ao tempo de sua celebração; b) nos contratos sobre coisas determinadas por seu gênero, o lugar do domicílio do devedor ao tempo em que foram celebrados; c) nos contratos sobre coisas fungíveis, o lugar do domicílio do devedor ao tempo de sua celebração; d) nos contratos que versem sobre prestação de serviços: 1 . se recaírem sobre coisas, o lugar onde elas existiam ao tempo de sua celebração; 2. se sua eficácia se relacionar com algum lugar especial, daquele onde houverem de produzir seus efeitos; 3. fora destes casos, o lugar do domicílio do devedor ao tempo da celebração do contrato."

425 “Artigo $9^{\circ}$ 1. Para os fins do artigo 7, alínea 'b', considerar-se-á domicílio do demandado: a) quando se tratar de pessoas físicas: 1 . sua residência, habitual; 2 . subsidiariamente, o centro principal de seus negócios e, 3. na ausência destas circunstâncias, o lugar onde se encontrar - a simples residência; b) quando se tratar de pessoa jurídica, a sede principal da administração. 2. Se a pessoa jurídica tiver sucursais, estabelecimentos, agências ou qualquer outra espécie de representação, será considerada domiciliada no lugar onde funcionem, sujeita à jurisdição das autoridades locais, no que concerne às operações que ali pratiquem. Esta qualificação não obsta o direito do autor de interpor a ação junto ao tribunal da sede principal da administração.”

${ }^{426}$ AGUIAR JÚNIOR, Ruy Rosado de. Protocolo de Buenos Aires sobre jurisdição internacional, cit., p. 194.
} 
correta. Como o Protocolo de Buenos Aires dá ao demandante várias opções para propor sua demanda - na hipótese de não haver a cláusula de eleição de jurisdição - como poderá o juiz do foro eleger o direito material que será aplicado ao caso? A lei do lugar do cumprimento do contrato, do juízo do domicílio do réu ou do juízo do domicílio do autor (quando demonstrado que cumpriu sua prestação)? Havendo diversos demandados, o artigo 12 do Protocolo ainda permite ao demandante propor a ação na jurisdição do Estado parte de quaisquer dos réus. Sem dúvida, essa regra torna a análise da exceção de incompetência, do ponto de vista do direito material, mais complexa do que se se aplicasse a velha regra kompetenz-kompetenz. ${ }^{427}$

As ações que se fundarem em garantia pessoal (excluídas as reais), intervenção de terceiros (denunciação à lide, oposição, nomeação a autoria, chamamento ao processo) devem ser propostas perante a corte que conhecer a ação principal. Já a reconvenção é permitida na hipótese de ter como fundamento um ato ou fato que serviu de base para a demanda principal (art. 13).

Para arrematar, a análise combinada dos três Protocolos parece favorecer o entendimento de que o forum shopping é institucionalizado no âmbito do Mercosul, pois:

a) O Protocolo de Buenos Aires dá ao demandante um amplo leque de jurisdições, à sua escolha (art. $7^{\circ}$ e 12), nos casos envolvendo obrigações contratuais;

b) O Protocolo de Las Leñas, por sua vez, parece fixar a competência do foro em que primeiro ocorreu a distribuição do feito, tornando-se ele prevento para as ações litispendentes e conexas (interpretação ampliada do artigo 22, in fine);

c) O Protocolo de Ouro Preto permite uma via rápida para o trâmite de cartas rogatórias oriundas de processos cautelares, possibilitando também a fixação da competência internacional do foro, inclusive, para as reconvenções (art. 13 do Protocolo de Buenos Aires) e as intervenções de terceiro.

\footnotetext{
${ }^{427}$ O princípio kompetenz-kompetenz (também chamado de compétence-compétence) é uma regra aplicável tanto à arbitragem quanto aos processos judiciais, que designa a faculdade que detém uma certa autoridade, seja ela política (como o Estado ou uma organização internacional), ou jurisdicional (juiz estatal ou árbitro) de delimitar por si próprio sua esfera de atividade, seu campo de intervenção ou, em resumo, seu papel naquele litígio. Seria a autodefinição, pelo julgador, de sua própria competência (BOUCARONNARDETTO, Magali. Le principe compétence-compétence en droit de l'arbitrage. Aix-en-Provence: Presses Universitaires d'Aix-Marseille, 2013). Ver também: KREINDLER, Richard H. Competencecompetence in the face of illegality in contracts and arbitration agreements. Recueil des Cours de l'Académie de Droit International de La Haye, v. 361, 2013.
} 


\subsection{Direito subjetivo e abuso do direito no forum shopping}

O direito subjetivo nada mais é do que um poder e uma faculdade advindos de uma regra interposta pelo Estado na proteção dos interesses coletivos. Vicente Rao conceitua o direito subjetivo como:

[...] o poder de ação determinado pela vontade que, manifestando-se através das relações entre as pessoas, recai sobre atos ou bens materiais ou imateriais e é disciplinado e protegido pela ordem jurídica, a fim de assegurar a todos e a cada qual o livre exercício de suas aptidões naturais, em benefício próprio, ou de outrem, ou da comunhão social. ${ }^{428}$

Washington de Barros Monteiro afirma que "o direito objetivo é o conjunto das regras jurídicas; direito subjetivo é o meio de satisfazer interesses humanos (hominum causa omne jus constitutum sit). O segundo deriva do primeiro". ${ }^{429}$

Direito objetivo corresponde à norma agendi, enquanto o direito subjetivo à facultas agendi. Este último apresenta-se como uma faculdade que o titular detém de usar o direito ou não a proteção do bem jurídico garantido pela norma agendi. Assim como o direito subjetivo está na sua possibilidade e potencialidade de uso, está também no seu exercício efetivo. ${ }^{430}$

No dizer de Helena Abdo, a noção de abuso do direito está intimamente ligada ao conceito de direito subjetivo. Inclusive, o abuso caracteriza-se justamente pelo exercício irregular de um direito subjetivo, ou seja, exercício do direito que excede os respectivos limites. Logo, o direito subjetivo constitui o verdadeiro objeto do abuso do direito. ${ }^{431}$

\footnotetext{
${ }^{428}$ RÁO, Vicente. O direito e a vida dos direitos. 5. ed. anotada e atual. por Ovidio Rocha Barros Sandoval. São Paulo: Revista dos Tribunais, 1999. p. 615.

${ }^{429}$ MONTEIRO, Washington de Barros. Curso de direito civil: parte geral. São Paulo: Saraiva, 1999. v. 1, p. 4.

${ }^{430}$ NUNES, Luiz Antônio Rizzatto. Manual de introdução ao estudo do direito. São Paulo: Saraiva, 1999. p. 111.

${ }^{431}$ ABDO, Helena Najjar, Abuso do processo, cit., p. 35.
} 
Grande parte da doutrina internacional, principalmente do common law, considera o forum shopping, por si próprio, uma forma de abuso processual ${ }^{432}$. Insta saber a real dimensão desse qualificativo, de acordo com o direito brasileiro.

\subsection{O abuso do direito no ordenamento jurídico brasileiro}

Pontes de Miranda trata de abuso do direito, ao invés de abuso de direito, pelo motivo de que não se abusa do ordenamento como um todo, mas de um determinado direito. O abuso aparece, justamente, no exercício de certo e determinado direito subjetivo de modo contrário à ordem jurídica. ${ }^{433}$

Segundo Menezes Cordeiro, a expressão "abuso do direito" surgiu com Laurent, que por sua vez tratou de uma série de decisões jurisprudenciais desfavoráveis àqueles que agiam na condição de titulares de um direito subjetivo. Naqueles casos, os tribunais optaram por não permitir que prevalecesse o direito invocado, embora reconhecessem sua existência, sob o fundamento de que havia irregularidade em seu exercício. Laurent cita vários exemplos ocorridos logo após a entrada em vigor do Código Napoleônico, tais como a condenação sofrida por um dono de oficina pelas evaporações desagradáveis oriundas da fabricação de chapéus, em 1808; ou, em outro caso, a determinação de que fosse destruída uma chaminé, em 1853, construída exclusivamente com a intenção de fazer sombra sobre o imóvel vizinho. Analogamente, em 1915, foi condenado o proprietário que havia construído um artefato dotado de espinhos de metal em seu imóvel, cujo propósito era o de rasgar os balões que sobrevoavam seu imóvel. ${ }^{434}$

Planiol criticou a doutrina do abuso do direito que, segundo ele, seria teoricamente contraditória: o direito cessaria onde teria começado o abuso, não podendo haver uso abusivo de um direito qualquer, na medida que um mesmo ato não poderia ser, ao mesmo tempo, conforme e contrário ao direito. ${ }^{435}$

\footnotetext{
432 JUENGER, Friedrich K., Forum shopping, domestic and international, cit., p. 553; MALOY, Richard, Forum shopping? What's wrong with that?, cit., p. 26.

433 PONTES DE MIRANDA, Francisco Cavalcanti. Comentários ao Código de Processo Civil: artigos 1 a 45. Atualização legislativa de Sérgio Bermudes. 5. ed. Rio de Janeiro: Forense, 1996. v. 1. p. 356.

${ }^{434}$ CORDEIRO, António Menezes. Da boa-fé no direito civil. Coimbra: Almedina, 1997. p. 670.

${ }^{435}$ PLANIOL, Marcel. Précis de droit civil. Paris: Dalloz, 1929. v. 1, p. 297.
} 
Josserand refutou a visão de Planiol, defendendo não existir contradição em que um ato seja ao mesmo tempo de acordo com um direito determinado e, entretanto, contrário ao direito considerado em sua generalidade e em sua objetividade. ${ }^{436}$

Não obstante a luta de palavras, é possível afirmar que a teoria do abuso do direito acabou por se consagrar em quase todos os ordenamentos jurídicos das nações desenvolvidas. $^{437}$

No Brasil, o início do estudo do tema abuso do direito se deu pelo direito processual, no âmbito do abuso da ação ou da defesa, especialmente quando o demandante propõe a ação para fins diversos daqueles que a norma supôs, objetivando prejudicar o réu ou terceiro. Já o abuso do direito de defesa se dá na hipótese em que o réu se defende de forma desproporcional, superando o que se poderia ter como razoável (negando fatos notórios ou apresentando recursos infundados). Para isso, o direito processual valeu-se, no início, da norma inscrita no artigo 160 do Código Civil de 1916, na falta de uma regra específica no direito processual sobre o tema. ${ }^{438}$

Considerando que "o direito de estar em justiça é um dos mais expostos à invasão do abuso e da malícia"439, o instituto sofreu imediata acolhida por parte dos processualistas, apesar de que somente a partir do CPC de 1939 tenha passado a contar com conceituação e repressão específicas. ${ }^{440}$

O artigo 188, I, do atual Código Civil é quase idêntico ao antigo artigo 160, I, do Código revogado. O novo artigo prevê que "não constituem atos ilícitos os praticados em legítima defesa ou no exercício de um direito reconhecido". Logo, o abuso do direito

${ }^{436}$ JOSSERAND, Louis. De l'esprit des droits et leur relativité. Théorie dite de l'abus des droits. Paris: Dalloz, 1927. p. 312.

${ }^{437}$ STOCO, Rui. Abuso do direito e má-fé processual: aspectos doutrinários. São Paulo: Revista dos Tribunais, 2002. p. 77. Diz o autor que o ato jurídico, porque encampado pela norma legal, pressupõe-se lícito. $\mathrm{O}$ ato contrário ao direito não é ato jurídico. Caracteriza um ato ilícito, segundo ele, posto não estar conforme o direito. Esse ato é ilícito desde a sua gênese: concepção, nascimento e efeitos que produz.

${ }^{438}$ THEODORO JÚNIOR, Humberto. Relatório brasileiro: abuso do direito processual no ordenamento jurídico brasileiro. In: MOREIRA, José Carlos Barbosa (Coord.). Abuso dos direitos processuais: relatórios ibero-americanos apresentados ao Simpósio da Associação Internacional de Direito Processual. Rio de Janeiro: Forense, 2000. p. 93.

${ }^{439}$ MARTINS, Pedro Baptista. $O$ abuso do direito e o ato ilícito. 3. ed. histórica, com considerações preliminares à guisa de atualização de José da Silva Pacheco. Rio de Janeiro: Forense, 1997. p. 71.

${ }^{440}$ CARDOSO, Vladimir Mucury. O abuso do direito na perspectiva civil-constitucional. In: MORAES, Maria Celina Bodin de (Coord.). Princípios do direito civil contemporâneo. Rio de Janeiro: Renovar, 2006, p. 45. 
continua sendo o exercício irregular de uma faculdade. Porém, o artigo 187 traz uma novidade, ao prever que o "titular de um direito que, ao exercê-lo, excede manifestamente os limites impostos pelo seu fim econômico ou social, pela boa-fé ou pelos bons costumes" comete ato ilícito.

\subsubsection{Abuso do direito processual}

Usualmente, a doutrina brasileira tem focado o abuso do direito processual pelo fato de o litigante propor uma ou mais ações judiciais buscando fazer prevalecer o que entende ser seu direito, mostrando, contudo, incoerência ou impertinência nos autos, criando incidentes, recorrendo sistematicamente de toda e qualquer decisão ou renovando a causa que já havia sido julgada. Basicamente, insistindo na busca de um resultado que lhe fora negado ou no reconhecimento de um direito declarado inexistente em decisão transitada em julgado. ${ }^{441}$

A liberdade de se propor uma demanda, tanto no aspecto doméstico como no internacional, é decorrência do princípio do acesso à Justiça, já tratado anteriormente. Porém, no abuso do direito, embora haja legitimidade no direito de ação, a consequência é que a demanda se mostra, o mais das vezes, abusiva em face do réu ou de terceiros. Por conta disso, muitos autores consideram que o abuso do direito traz consigo o dever de indenizar. $^{442}$

Por isso vale a advertência de Pedro Baptista Martins, de que o exercício da demanda não é um direito absoluto, posto se achar, também, condicionado a um motivo legítimo. Quem recorre às vias judiciais deve ter um direito a reintegrar, um interesse legítimo a proteger, ou pelo menos, como ocorre nas ações declaratórias, uma razão séria para invocar a tutela jurídica. Por isso, conclui o autor, "a parte que intenta ação vexatória incorre em responsabilidade, porque abusa de seu direito". 443

${ }^{441}$ STOCCO, Rui, Abuso do direito e má-fé processual: aspectos doutrinários, cit., p. 76.

${ }^{442}$ ARAÚJO, Francisco Fernandes de. O abuso do direito processual e o princípio da proporcionalidade na execução civil. Rio de Janeiro: Forense, 2004. p. 57.

${ }^{443}$ MARTINS, Pedro Baptista, $O$ abuso do direito e o ato ilícito, cit., p. 71. 


\subsubsection{Critérios para identificação do abuso}

Segundo Helena Abdo, todas as teorias que procuraram estabelecer os critérios do abuso do direito convergiram em três noções pacíficas: (a) a aparência de legalidade de que o abuso é revestido; (b) a preexistência de um direito subjetivo (só se pode abusar de um direito que se tem); e (c) o fato de que o abuso refere-se fundamentalmente ao exercício do direito e não ao direito em si. ${ }^{444}$

O jurista italiano Giorgio Pino arrola os seguintes elementos constitutivos do abuso: (a) a titularidade de um direito subjetivo (por meio da garantia de um campo de ação em que a vontade do titular do direito serve para delimitar o âmbito em que o indivíduo possa atuar independentemente da vontade de outrem); (b) a possibilidade de que o exercício desse direito possa ser efetuado numa pluralidade de hipóteses, não rigidamente predeterminadas; (c) que o exercício concreto do direito, ainda que esteja formalmente de acordo com o ordenamento, tenha como consequência um resultado "censurável" (aberranti, deprecabili, abnormi etc.), em comparação com alguns critérios de avaliação, processuais ou extraprocessuais; (d) pelo fato de que o direito foi exercido de modo “censurável”, verificando-se uma desproporção injustificada entre o benefício do titular do direito e o sacrifício sofrido pela outra parte. ${ }^{445}$

Uma possível taxonomia dos critérios efetivamente utilizados para identificação de abuso do direito processual é dividido em critérios intencionais-subjetivos, critérios econômicos, critérios morais e critérios teleológicos. ${ }^{446}$

A teoria da intenção subjetiva do abuso está ligada ao animus nocendi, ou seja, um ato de exercício de um direito é abusivo se o titular tem a intenção de causar um dano à outra parte, não obstante a aparência de legitimidade dos meios. A jurisprudência brasileira possui muitos exemplos, fundados, por exemplo, no abuso do direito de recorrer, com a

\footnotetext{
${ }^{444}$ ABDO, Helena Najjar, Abuso do processo, cit., p. 37.

${ }^{445}$ PINO, Giorgio. Il diritto e il suo rovescio: appunti sulla dottrina dell'abuso del diritto. Rivista Critica del Diritto Privato, v. 1, p. 32, 2004. Em cada etapa dessa definição encontra-se um conjunto de problemas controversos, tanto no plano teórico, quanto no dogmático, lembra o autor.

${ }^{446}$ PINO, Giorgio. L'abuso del diritto tra teoria e dogmatica (precauzioni per l'uso). In: MANIACI, Giorgio (Org.). Eguaglianza, ragionevolezza e logica giuridica. Milano: Giuffrè, 2006. p. 137.
} 
propositura em cascata de embargos de declaração ${ }^{447}$. A grande dificuldade dessa teoria é a comprovação de que o titular do direito agiu com a intenção de causar prejuízo a outrem, o que seria por demais restritivo. ${ }^{448}$

A teoria econômica do abuso do direito leva em conta o critério de valoração da eficiência, inspirado no critério de eficiência do tipo paretiano. Em linhas gerais, a opção do demandante em piorar a situação econômica do adversário, sem que com isso melhore a sua própria situação, viola os critérios de eficiência de Pareto e, em última análise, comete um abuso do direito ${ }^{449}$. Novamente, esse critério pode ser difícil de apurar na prática, levando em conta a necessidade de se demonstrar que o demandante estava no controle das opções, bem como o cálculo do prejuízo em si pode ser posto em dúvida, considerando a possibilidade de outros critérios que não os meramente econômicos. ${ }^{450}$

$\mathrm{O}$ aspecto moral, em princípio, parece ser o maior inspirador da ideia de abuso do direito, pois o próprio termo transmite um juízo de valor negativo de amplo sentido moral. Por conta disso, esse aspecto parece criar igualmente riscos, ao permitir - por exemplo que o tribunal faça uso de seu próprio critério de avaliação. Evidentemente, parece não ser apropriado que uma decisão judicial se baseie exclusivamente em uma avaliação pessoal, pois isso pode criar situações contraditórias. ${ }^{451}$

Finalmente, os critérios teleológicos são os mais comuns na literatura sobre o abuso do direito, posto que o instituto vem sendo qualificado como uma distorção jurídica, no que diz respeito à sua função típica, sua razão de ser e seus princípios fundamentais dentro

447 STJ: ED ED ED REsp n. 1.236.276/SP; ED ED ED AgR EAREsp n. 228.004/SP; ED ED ED AgR AREsp n. 28.328/RJ; ED ED ED AgR ED REsp n. 1.418.630/PB.

448 TORRENTE, Andrea. Emulazione (diritto civile). In: NOVISSIMO Digesto Italiano. Torino: UTET, 1975. v. 6, p. 521.

449 RÜHL, Giesela. Choice of law and choice of forum in the European Union: recent developments. In: HODGES, Christopher; VOGENAUER, Stefan (Coords.). Civil justice systems in Europe: implications for choice of forum and choice of contracts law. Oxford: Hart, 2010. p. 5.

${ }^{450}$ ROSENFELD, Michel. Just interpretations: law between ethics and politics. Berkeley: University of California Press, 1998. p. 24.

${ }^{451}$ MACCORMICK, Neil. Universalisation and induction in law. In: FARALLI, Carla; PATTARE, Enrico (Coords.). Reason in law. Milano: Giuffrè, 1987. v. 1. p. 99. Na MC n. 15.398/RJ, já referida anteriormente, o STJ extinguiu uma ação cautelar inominada preparatória de recurso especial, por sua vez interposto contra a extinção de uma ação de indenização movida por uma empresa de engenharia em face da Petrobras, sob o argumento de que a mesma ação já havia sido proposta entre as mesmas partes, na Inglaterra, com resultado desfavorável à empresa de engenharia. Assim, muito embora a sentença inglesa de improcedência ainda não tivesse sido homologada pelo STJ, a propositura da mesma ação proposta na Inglaterra em tribunais brasileiros configurava um ato de violação à boa-fé objetiva. 
do ordenamento jurídico ${ }^{452}$. Josserand cita a noção de espírito dos direitos, critério abstrato e superior do qual decorrem dois outros critérios: o do motivo legítimo (que traz uma carga de subjetivismo) e o da função social (que é o critério objetivo). Logo, para esse autor, o abuso do direito decorre sempre do exercício de uma prerrogativa jurídica (que é o elemento subjetivo da escolha), que por sua vez ocasiona uma lesão ao "espírito" do direito. A prova da abusividade na escolha cabe a quem alega, segundo Josserand, cujas ocorrências estariam materializadas em casos de conluio, fraude, dolo, intenção de prejudicar a outrem e má-fé. ${ }^{453}$

\subsection{Forum shopping e abuso processual}

De uma forma geral, a doutrina internacional analisa o forum shopping por dois ângulos principais: (a) o realista, que encara a escolha do foro como um fato a ser tolerado, posto que incontrolável; ou (b) o abusivo, que considera seu exercício um prejuízo ao sistema legal visto em sua integralidade.

No primeiro grupo, Collins, em 1976, já havia apontado que o exercício do forum shopping se daria em quaisquer Estados em que houvesse divergência nas regras de direito internacional privado, e que permitissem ao demandante que escolhesse a jurisdição que lhe fosse mais familiar, onde ele tivesse maiores vantagens processuais, ou ainda onde ele pudesse expor o demandado a grandes desvantagens processuais ${ }^{454}$. Lord Simon Glaisdale, juiz da Court of Appeals da Inglaterra, em 1973, em precedente já mencionado anteriormente, afirmou que o forum shopping não poderia ser considerado uma expressão chula, mas apenas uma forma pejorativa de qualificar a escolha dada ao demandante quanto à jurisdição que se mostrasse a ele mais favorável. Essa opção, segundo Lord Glaisdale, "não deveria causar nem surpresa nem indignação" 455 . Como já mencionado anteriormente, o juiz da Court of Appeals da Inglaterra Lord Denning, em 1982, declarou que os Estados Unidos atraíam litigantes que buscavam polpudas indenizações, como "mariposas eram atraídas pela luz". 456

\footnotetext{
452 CORDEIRO, António Menezes. Do abuso do direito: estado das questões e perspectivas. Revista da Ordem dos Advogados, Lisboa, ano 65, v. 2, p. 330, set. 2005.

${ }^{453}$ JOSSERAND, Louis, De l'esprit des droits et leur relativité.., cit., p. 406.

454 COLLINS, Lawrence. Contractual obligations - the EEC preliminary draft convention on private international law. International and Comparative Law Quarterly, v. 25, No. 1, p. 35, Jan. 1976.

${ }^{455}$ Caso The Atlantic Star (1974) AC 436 at 47.

${ }^{456}$ Caso Smith Kline \& French Laboratories Ltd $v$. Bloch [1983] 2 All ER 72 at 74 (CA).
} 
No segundo grupo, três razões são apontadas para considerar o forum shopping um exercício prejudicial ao sistema jurídico. A primeira delas refere-se ao desprestígio ou o enfraquecimento do direito material de um determinando Estado, que é preterido pelo demandante; a segunda razão refere-se ao assoberbamento dos tribunais de certas jurisdições que são mais escolhidas, o que leva a um maior gasto tanto desses Estados como dos próprios litigantes; por fim, a terceira razão é a de evitar o descrédito da equidade do sistema judicial como um todo. ${ }^{457}$

Essa discussão doutrinária alterna-se entre uma posição realista, que considera o forum shopping inevitável, devendo apenas ser coibidas práticas consideradas abusivas ${ }^{458} \mathrm{e}$ outra posição funcionalista, que opõe-se sistematicamente ao forum shopping, por conta de um possível risco sistêmico ao ordenamento jurídico. ${ }^{459}$

No direito brasileiro, não é possível se afirmar que o forum shopping possa ser considerado, a priori, um abuso do direito do demandante, na medida que o NCPC e o sistema de competência internacional o permitem, como já demonstrado anteriormente. Para verificação do abuso a posteriori, a escolha da jurisdição mais favorável deve ser analisada dentro da teoria do abuso do direito, por meio de suas projeções. São elas a violação do dever de lealdade e o uso do processo para atingimento de objetivo ilegal.

\subsubsection{Dever de lealdade}

O julgamento do caso International Shoe pela Suprema Corte americana em 1945, como mencionado anteriormente, representou um marco no estudo do forum shopping, no dizer de Cameron e Johnson, "para o bem ou para o mal". Enraizou-se a doutrina do "fair play and substantial justice", com uma maciça produção acadêmica sobre o tema. Reagindo ante situações "injustas”, as cortes americanas passaram a analisar a escolha do

\footnotetext{
${ }^{457}$ FORUM shopping reconsidered. Harvard Law Review, v. 103, n. 7, p. 1.677-1.696, May 1990.

${ }^{458}$ Inclusive, punindo os advogados que as promoverem (SHAFFER, Thomas L. Unique, novel, and unsound adversary ethic. Vanderbilt Law Review, v. 41, p. 712, 1988).

${ }^{459}$ RAWLS, John. A theory of justice. Cambridge, MA: Belknap Press of Harvard University Press, 1971. p. 72. Concepções morais populares sobre o direito e a justiça refletem uma crença predominante de que o destino rege os resultados promulgados pelas cortes. Logo, a crença popular é que seria possível manipular esses elementos (direito e justiça) em proveito próprio.
} 
foro pelo demandante, recusando-a como proteção aos réus em certos casos, evitando resultados "injustos". 460

No civil law, a análise de que uma escolha de jurisdição possa ser "justa" ou “injusta” passa pela lealdade processual, naquilo que levou Calamandrei a comparar o processo com um jogo. A lealdade processual seria nada mais que o fair play na atuação das partes, sem que elas abandonem seus interesses - a prestação jurisdicional favorável mas atuem de maneira a obter tal prestação sem que se atrapalhe a evolução do agir do adversário. $^{461}$

Nas palavras de Humberto Theodoro Júnior, “o processo judicial tem muito de jogo, competição. Nesta disputa, é claro que a habilidade é permitida, mas não a trapaça". 462

Dentro da ideia de fair play processual, as partes possuem liberdade de ação como contraponto para a limitação oferecida pelo dever de lealdade processual. Ao eleger um dentre vários atos possíveis de serem desempenhados, ou ao se desincumbir de um ônus, as escolhas dos jurisdicionados devem ser livres, mas devem ser leais. ${ }^{463}$

Em se tratando de forum shopping, regulado pela pelas normas de direito de cada Estado que, de maneira não organizada, permitem a concorrência entre uma ou mais jurisdições, o que poderia ser considerada uma deslealdade processual?

Numa primeira hipótese, a possibilidade de se escolher uma jurisdição exorbitante, tal como definida e analisada anteriormente, pode ser considerada um desses casos de deslealdade processual. A falta de vinculação do litígio com o foro (minimum contact) e a

\footnotetext{
${ }^{460}$ CAMERON, Christopher D.; JOHNSON, Kevin R., Death of a salesman? Forum shopping and outcome determination under international shoe, cit., p. 828.

${ }^{461}$ CALAMANDREI, Piero, Il processo come giuoco, cit., p. 44.

462 THEODORO JÚNIOR, Humberto. O princípio da probidade e a repressão à litigância de má-fé. COAD Seleções Jurídicas, v. 11, p. 18, 1990.

${ }^{463}$ LEAL, Stela Tannure. Lealdade processual, dever de veracidade e estado social. Revista Ética e Filosofia Política, Juiz de Fora, MG, UFJF, v. 2, n. 15, p. 97, dez. 2012.
} 
mera competência internacional baseada em critérios soberanísticos não parece estar em sintonia com a evolução do direito internacional. ${ }^{464}$

Numa segunda hipótese, a escolha do foro pode se basear na possibilidade de se causar um grave prejuízo ou uma enorme dificuldade ao demandado. É o que a doutrina inglesa denominou como uma competência "vexatória e opressiva". Um exemplo é o "pretrial discovery", instituto desconhecido no processo civil brasileiro. Muitos sistemas jurídicos determinam que as partes franqueiem umas às outras suas informações privadas, antes de iniciarem os procedimentos judiciais. No sistema brasileiro, as partes produzem suas provas após o contraditório inicial do processo judicial, na fase probatória. A doutrina internacional considera o "pre-trial discovery" um instituto muito custoso, pois muitas vezes quantidades maciças de documentos são entregues aos defensores da parte, que por sua vez têm um curto lapso de tempo para analisá-los, o que encarece sobremaneira o litígio. Outros institutos processuais desconhecidos, tais como o julgamento civil por júri, regras específicas sobre o pagamento de custas e honorários de sucumbência, bem como liminares específicas (como a anti-injuction lawsuit, que será analisada oportunamente), podem ser considerados - em casos específicos - artifícios desleais. ${ }^{465}$

\subsubsection{Uso do processo para atingimento de objetivo ilegal}

Segundo Barbosa Moreira, "usar o processo para conseguir objetivo ilegal" significa expor a parte contrária à desonra pública, abalar-lhe o crédito, exercer sobre ela pressão psicológica ou econômica, para obter favores ou vantagens indevidas etc. ${ }^{466}$

Acrescenta Helena Abdo corresponder a um desvio de finalidade como principal elemento do abuso do processo, ao lado da aparência de legalidade e do uso livre (não vinculado) de uma ou mais situações subjetivas processuais. ${ }^{467}$

Embora não haja muitos trabalhos doutrinários e mesmo decisões jurisprudenciais sobre a hipótese do uso do processo para atingimento ilegal no Brasil, resta a questão

\footnotetext{
${ }^{464}$ FERNÁNDEZ ARROYO, Diego P. Compétence exclusive et compétence exorbitante dans les relations privées internationales. Recueil des Cours de l'Académie de Droit International de La Haye, v. 323, p. 9259, 2006.

465 JUENGER, Friedrich K. What's wrong with forum shopping?, cit., p. 5.

${ }^{466}$ MOREIRA, José Carlos Barbosa. A responsabilidade das partes por dano processual no direito brasileiro. In:__. Temas de direito processual civil: primeira série. São Paulo: Saraiva, 1988. p. 27.

${ }^{467}$ ABDO, Helena Najjar, Abuso do processo, cit., p. 159.
} 
melhor analisada sob os auspícios da litigância de má-fé em geral ${ }^{468}$ no âmbito da União Europeia, onde muitos são os exemplos de utilização do processo com manifesto desvio de finalidade.

Conforme já discorrido anteriormente, o sistema Bruxelas-Lugano (Regulamento (EU) 1.215/2012) criou um mecanismo que evita a litispendência e a conexão internacional entre seus Estados membros, por meio do mecanismo denominado lis pendens rule. ${ }^{469}$

A intenção da regra foi evitar que ações conexas ou litispendentes pudessem tramitar em várias jurisdições da União Europeia, com resultados contraditórios, em afronta ao espírito do direito da integração.

Ocorre que diversos litigantes têm utilizado a regra do artigo 29 do sistema Bruxelas-Lugano, definidora da lis pendentes rule, com o propósito de uso de um forum shopping reverso: os possíveis demandados pelo incumprimento de obrigações (sejam elas contratuais ou aquilianas), na iminência de se verem réus em ações condenatórias, se antecipam ao litígio, propondo demandas contra seus credores, em jurisdições previamente escolhidas, e normalmente diferentes daquelas que seriam utilizadas pelos mesmos credores. Grande parte das vezes, o único propósito desses forum shoppers é o de evitar o trâmite da ação em que seriam compelidos a cumprir sua obrigação, muitas vezes, por longos anos. ${ }^{470}$

\footnotetext{
${ }^{468}$ LIMA, Patricia Carla de Deus. O abuso do direito de defesa no processo civil: reflexões sobre o tema no direito e na doutrina italiana. Revista de Processo, São Paulo, Revista dos Tribunais, v. 30, n. 122, p. 96, abr. 2005; LOPEZ, Teresa Ancona. Exercício do direito e suas limitações: abuso do direito. Revista dos Tribunais, São Paulo: Revista dos Tribunais, v. 98, n. 885, p. 52, jul. 2009; e STOCO, Rui, Abuso do direito e má-fé processual: aspectos doutrinários, cit., p. 68.

${ }^{469} \mathrm{O}$ artigo 29 do Regulamento 1.215/2012 determina que qualquer tribunal que não seja demandado em primeiro lugar deve suspender oficialmente o trâmite do processo até que seja estabelecida a competência do tribunal demandado em primeiro lugar. "O facto de haver jurisdições alternativas para os litígios regulados pela Convenção torna possível que a mesma acção seja submetida à apreciação de tribunais de diferentes Estados vinculada pela Convenção, com o risco de serem pronunciadas decisões incompatíveis entre si. A fim de assegurar o bom funcionamento do sector da justiça num espaço judiciário comum, esse risco deverá minimizado, evitando sempre que possível que em simultâneo sejam instruídas acções paralelas em diferentes Estados-Membros." (Convenção relativa à competência judiciária, ao reconhecimento e à execução de decisões em matéria civil e comercial assinada em Lugano, em 30 de Outubro de 2007 - Relatório explicativo do Professor Fausto Pocar, Titular da cátedra de Direito Internacional da Universidade de Milão. Jornal Oficial da União Europeia C 319 de 23.12.2009, p. 31). Disponível em: $<$ http://eur-lex.europa.eu/legalcontent/PT/TXT/PDF/?uri=OJ:C:2009:319:FULL\&from=PT>. Acesso em: 20 jun. 2015).

${ }^{470}$ HARTLEY, Trevor C. How to abuse the law and (maybe) come out on top: bad-faith proceedings under the Brussels jurisdiction and judgments conventions. King's College Law Journal, v. 13, No. 2, p. 142, 2002.
} 
O mais clamoroso exemplo desse tipo de estratégia - forum shopping reverso - são os denominados “torpedos”, que serão examinados oportunamente.

Para os países com tradição no common law, a maneira de se evitar tal tipo de uso do processo para atingir objetivo ilegal é justamente a propositura de uma anti-suit injuction em face do demandante que se antecipou no forum shopping reverso, ao propor sua demanda defensiva (declaratória) numa jurisdição em princípio incorreta.

Anti-suit injunctions são medidas processuais de natureza inibitória, cujo propósito é o de obrigar a parte contrária a não iniciar um processo em outra jurisdição (isto é, diferente daquela que deferiu a injuntion) ou, uma vez iniciado, que desista da demanda estrangeira, sob pena de lhe serem impostas medidas coercitivas (contempt of court). A eficácia da anti-suit injuction, portanto, reverbera para além da jurisdição em que foi concedida, como forma de manter a autoridade do órgão judicante que a proferiu, que por sua vez considerou o foro escolhido pelo réu em outra jurisdição "opressivo" ou "abusivo". Evidentemente, trata-se de um remédio processual desconhecido nos países da tradição do civil law, sendo deveras utilizado nos do common law, como a Inglaterra. ${ }^{471}$

Porem, como já visto anteriormente, o Tribunal de Justiça da União Europeia (TJUE), no caso Turner $v$. Grovit ${ }^{472}$, considerou que as anti-suit injuctions oriundas dos tribunais ingleses eram incompatíveis com o Regime de Bruxelas-Lugano e, portanto, não poderiam se sobrepor à lis pendens rule. Em outras palavras, o TJUE considerou que as anti-suit injuctions eram processos que visavam a um objetivo ilegal (de se imiscuir na competência internacional de outro Estado), ao lado dos famigerados torpedos $^{473}$. O TJUE tolerou os torpedos, mas não as anti-suit injuctions.

\footnotetext{
${ }^{471}$ RÜHL, Giesela, Choice of law and choice of forum in the European Union: recent developments, cit., p. 17; LOWENFELD, Andreas, Forum shopping, antisuit injunctions, negative declarations, and related tools of international litigation. Editorial comment, cit., p. 320; VON MEHREN, Arthur Taylor, Theory and practice of adjudicatory authority, cit., p. 398.

${ }^{472}$ Caso C-159/02 Turner v. Grovit (2004).

${ }^{473} \mathrm{O}$ Tribunal de Justiça não analisou a competência da corte inglesa em termos de direitos subjetivos, contratos, enfim, direito privado. O acórdão deixou claro, em Gasser $v$. Turner, que a questão analisada era o direito internacional público, quanto às regras de competência que eram sua única preocupação (RIGGS, Adrian. The impact of recent judgments of the European Court on english procedural law and practice. Zeitschrift fur Schweizerisches Recht, v. 2, n. 124, p. 233, 2005).
} 


\section{CAPÍTULO 4 - FORUM SHOPPING E ABUSO DO DIREITO PROCESSUAL - CASUÍSTICA INTERNACIONAL}

\subsection{O torpedo italiano: conexão de processos no âmbito da União Europeia}

Como regra geral do Regulamento (CE) 1.215/2012, vigente para os Estados membros da União Europeia e Estados associados, também denominado sistema BruxelasLugano ou Brussels Regulation, o réu deve ser demandado na jurisdição de seu domicílio, independentemente de sua nacionalidade, conforme determina o artigo $4^{\circ}$. Essa é a regra actor sequitur forum rei.

Esse mesmo regramento dá ao autor, muitas vezes, a faculdade processual de escolher onde propor sua demanda, dentre várias jurisdições. Exemplificativamente, nos casos envolvendo responsabilidade civil ex delictu, pode o autor optar - licitamente - por demandar o infrator na jurisdição onde este tenha domicílio ou na jurisdição onde o evento danoso ocorreu ou poderá ocorrer (art. $7^{\circ}$, alínea 2).

Num litígio envolvendo infração ao direito de patentes, que por sua vez enquadrase na modalidade de ação condenatória oriunda justamente na responsabilidade civil ex delictu, é comum que a parte lesada envie à parte infratora uma notificação ou aviso de que pretende cessar o uso não autorizado da propriedade intelectual dentro de um determinado prazo.

Como vem sendo noticiado pela doutrina europeia ${ }^{474}$, a parte infratora, nesses casos, tem se antecipado na propositura de uma ação declaratória em face da parte notificante, buscando que se declare judicialmente a inexistência de violação ao direito alegado. Em princípio, pode o infrator propor uma ação declaratória em qualquer dos Estados membros da União Europeia, mesmo em Estados onde nenhuma das partes tenha

\footnotetext{
${ }^{474}$ BORCHERS, Patrick J. The real risk of forum shopping: a dissent from Shady Grove. Creighton Law Review, v. 44, p. 30, 2011; CLERMONT, Kevin M.; EISENBERG, Theodore, Exorcising the evil of forum shopping, cit., p. 1.508; JUENGER, Friedrich K. What's wrong with forum shopping?, cit., p. 6; KOEHNEN, Markus, Reasonable expectations and a principled approach to forum shopping, cit., p. 312.
} 
seu domicílio ou nacionalidade, bastando a alegação de que o produto cuja patente esteja sub judice tenha sido comercializada naquele Estado membro, dentre outras alegações. ${ }^{475}$

Evidentemente, o infrator pode escolher a jurisdição onde é mais provável que venha a ter sucesso em seu pleito, ou - no pior dos casos - na jurisdição cujo trâmite processual seja tão lento que permita a continuidade delitiva durante certo lapso temporal, impedindo a parte prejudicada de prosseguir com sua demanda condenatória em outro Estado membro.

Ocorrendo a propositura de uma ação declaratória por parte do infrator num Estado membro, antes que a parte lesada tenha proposto sua demanda condenatória em outro Estado membro, como resultado da regra do artigo 29 do Regulamento (CE) 1.215/2012, a mencionada propositura da ação declaratória impede o ofendido de prosseguir com sua demanda em qualquer dos Estados vinculados ao Regime de Bruxelas, isto é, todos os Estados membros da União Europeia, mais a Islândia, a Noruega e a Suíça.

E como apontado por muitos especialistas, as partes acusadas como violadoras "conscientes" dos direitos de patentes têm procurado propor suas ações declaratórias justamente em jurisdições tidas como as mais lentas $^{476}$ da Europa.

Essa prática de escolha da jurisdição mais lenta para julgar a ação declaratória (defensiva ou forum shopping reverso) que, pela aplicação do artigo 29 do Regulamento (CE) 1.215/2012 impede o prosseguimento da ação condenatória por parte da parte prejudicada pelo uso indevido da propriedade intelectual, foi detectada em primeiro lugar pelo advogado italiano Mario Franzosi ${ }^{477}$, justamente ao constatar que diversas ações declaratórias estavam sendo propostas na Itália, com o claro propósito de suspender as

\footnotetext{
475 "In the case where a patent granted in different EC countries infringed by the same entity or several interrelated entities, the patentee has two possibilities to litigate: a series of national litigation proceedings (namely different proceedings before the various courts in the territory where the infringement took place) or European-wide litigation by filing an application for a cross-border injunction. In the former case the patentee may run the risk of obtaining an unfavorable judgment in one country, which might then affect the result of the other proceedings." (JANDOLI, Vincenzo. The "italian torpedo". International Review of Intellectual Property and Competition Law IIC, Munich, v. 31, p. 783, 2000).

${ }^{476}$ HARTLEY, Trevor C., How to abuse the law and (maybe) come out on top: bad-faith proceedings under the Brussels jurisdiction and judgments conventions, cit., p. 140.

477 FRANZOSI, Mario. Worldwide patent litigation and the italian torpedo. Disponível em: <http://www.franzosi.com/articolo/1997/worldwide-patent-litigation-and-the-italian-torpedo>. Acesso em: 23 maio 2015
} 
ações condenatórias propostas em outras jurisdições, em casos de infração ao direito de patentes.

Em seu artigo de 1997, Franzosi construiu uma metáfora entre a regra do artigo 29 e um comboio de navios. Como corolário lógico, um comboio hipotético navegará na velocidade de seu navio mais lento; caso contrário não haveria comboio, pois os navios mais lentos ficariam para trás. Se um navio tem problemas técnicos (por exemplo, tendo sido alvejado por um "torpedo"), todos os outros navios devem ancorar e ali permanecer, até que o navio avariado tenha sido reparado ${ }^{478}$. Em síntese, a ação declaratória faz com que a ação condenatória fique "ancorada", até que a corte decida sobre sua própria competência, o que pode levar anos.

Dessa metáfora, Franzosi criou a expressão "torpedo italiano", cujo uso se popularizou-se na doutrina do direito internacional privado europeu.

Havendo a possibilidade de concorrência entre duas ou mais jurisdições europeias dirimirem a mesma lide, o tempo de duração do processo é um importante componente de análise da jurisdição - em tese - mais favorável ao pleito do autor, principalmente em questões relacionadas à inadimplência ou violação de patentes ${ }^{479}$, em que a suspensão da demanda condenatória permitirá a continuidade delitiva.

A Itália tem sido sistematicamente denunciada ${ }^{480}$ perante o Tribunal Europeu dos Direitos Humanos por violação o artigo $6^{\circ}$ (1) da Convenção Europeia dos Direitos Humanos, que por sua vez consagra o direito a um julgamento dentro de um prazo razoável:

\footnotetext{
Artigo $6^{\circ}$ (Direito a um processo equitativo)

1. Qualquer pessoa tem direito a que a sua causa seja examinada, equitativa e publicamente, num prazo razoável por um tribunal independente e imparcial, estabelecido pela lei, o qual decidirá, quer sobre a determinação dos seus direitos
}

\footnotetext{
${ }^{478}$ FRANZOSI, Mario, Worldwide patent litigation and the italian torpedo, cit.

${ }^{479}$ HARTLEY, Trevor C., How to abuse the law and (maybe) come out on top: bad-faith proceedings under the Brussels jurisdiction and judgments conventions, cit., p. 143.

${ }^{480}$ De acordo com o Overview 1959-2012 do Tribunal Europeu dos Direitos Humanos, a Itália foi denunciada 1.171 vezes por demora na prestação jurisdicional, sendo que tais denúncias correspondem a mais de $23 \%$ de todas as denúncias formuladas contra todos os demais 27 países que compõem a União Europeia (Disponível em: <http://www.echr.coe.int/Documents/Stats_violation_1959_2012_ENG.pdf>. Acesso em: 27 out. 2013).
} 
e obrigações de caráter civil, quer sobre o fundamento de qualquer acusação em matéria penal dirigida contra ela. O julgamento deve ser público, mas o acesso à sala de audiências pode ser proibido à imprensa ou ao público durante a totalidade ou parte do processo, quando a bem da moralidade, da ordem pública ou da segurança nacional numa sociedade democrática, quando os interesses de menores ou a proteção da vida privada das partes no processo o exigirem, ou, na medida julgada estritamente necessária pelo tribunal, quando, em circunstâncias especiais, a publicidade pudesse ser prejudicial para os interesses da justiça.

Os efeitos do Regime de Bruxelas foram nefastos, ao privilegiar o improbus litigator que, abusando da situação das cortes italianas, propõem ações declaratórias com o claro propósito de impedir a propositura das ações condenatórias contra si em outras jurisdições menos convenientes. ${ }^{481}$

Os tribunais belgas também disputam com a Itália a desonrosa posição de terem os julgamentos mais lentos em matéria de propriedade intelectual, o que também levou seus tribunais a receber um grande volume de ações declaratórias negativas, ou seja, uma verdadeira prática de torpedos belgas. ${ }^{482}$

Ao contrário dos tribunais italianos e belgas, a doutrina tem apontado que os torpedos não funcionam tão bem nos litígios de patentes na Alemanha. Os tribunais alemães são considerados mais rápidos e mais baratos, de acordo com os relatórios da Corte Europeia de Direitos Humanos, havendo tribunais especializados nessa matéria, o que acelera os julgamentos. A Alemanha recebe anualmente cerca de 600 litígios, de um total aproximado de 1.500 casos que envolvem violações de patentes nos tribunais

${ }^{481}$ STANKO, Andrej. Cross border “torpedo" litigation. Common Law Review, n. 10, p. 23, 2009. Segundo o autor, em 2003, a Itália criou 12 tribunais especializados em conflitos envolvendo propriedade intelectual. Porém, ainda sim, um julgamento em primeira instancia ainda levava não menos que três anos.

482 "Not so long ago, at the end of the twentieth century, patent litigation in Belgium was considered complex and not rewarding because of the slowness of legal proceedings, the appointment of court experts who knew hardly more about patents than the judges who appointed them, law practitioners who were unwilling to read and understand technical issues, and the court's reluctance to award damages that adequately compensated a patent owner for his loss of investment in pursuing the infringement. These deficiencies culminated in the so-called Belgian torpedo strategy, whereby the Belgian (more particularly the Brussels) court was flooded with claims for cross-border declaratory judgment of non-infringement. These claims were filed with the sole purpose of frustrating foreign infringement proceedings, taking (unfair) advantage of the rule of lis pendens contained in the Brussels Convention (now the EEX Regulation). Conducting such a procedure was the ultimate example of Belgian judicial surrealism: plaintiffs behaved like defendants, by delaying the procedure as much as possible and avoiding the court taking any decision whatsoever. The defendant/patent holder, on the other hand, either did nothing and let the case rest with the Belgian court, or complained before a foreign court about the incapacity of the Belgian court to deal with this practice and the necessity to terminate it. No attempt was made by any Belgian practitioner to challenge this practice from within the system." (VANDERMEULEN, Bruno. The next generation of cross-border litigators. Disponível em: <http://www.managingip.com/Article/1321504/The-next-generation-of-crossborder-litigators.html >. Acesso em: 27 out. 2013). 
nacionais na União Europeia ${ }^{483}$. Tal preferência tem se dado justamente pelos lesados na infração (autores das ações condenatórias).

Mesmo nos conflitos relacionados à responsabilidade contratual, em que houve eleição de foro, o TJUE aplicou a regra de litispendência e conexão prevista no Regime de Bruxelas-Lugano e permitiu o uso de um torpedo no leading case Gasser $^{484}$, já mencionado anteriormente. Isso mostra a plena validade da estratégia do forum shopping reverso, com o fim - muitas vezes - de abuso do processo.

E o abuso, neste caso, relaciona-se com a duração do processo ${ }^{485}$, que dentro das medidas reconhecidas inclusive pela Corte Europeia de Direitos Humanos, não deve ser excessiva.

O decurso do tempo destempera a boa qualidade do provimento jurisdicional, quando a demora traz prejuízos, sofrimentos, ansiedades e quando, tantas vezes, o provimento tardio acaba por se tornar dispensável ou inútil. ${ }^{486}$

Visando a evitar as práticas abusivas oriundas dos torpedos, os tribunais belgas e italianos têm levado em conta o possível abuso processual na propositura das ações declaratórias em suas jurisdições. ${ }^{487}$

No caso Macchine BL, a Suprema Corte italiana declinou de sua competência em uma ação declaratória, julgando-se incompetente em todos os assuntos que dizem respeito a tais demandas ${ }^{488}$. Em relação à competência prevista no Regime de Bruxelas, o tribunal

\footnotetext{
${ }^{483}$ BODONI, Stéphanie. Where to find value in Europe. Managing Intellectual Property, p. 30, set. 2004.

${ }^{484}$ Caso C-116/02, Erich Gasser GmbH v. MISAT Srl, Oberlandesgericht Innsbruck (Austria).

${ }^{485}$ Como já disse Francesco Carnelutti: "Il problema del procedimento, come dice la stessa parola, poiché 'procedere' significa 'andare innanzi', há um suo aspetto temporale, il quale è pure importante e interessante. Qui la parola tempo è intense prima di tutto come 'durata' cioè come distanza tra l'inizio e la fine di uno svolgimento e pertanto come necessita di attesa. Il processo dura; non si può fare tutto in una volta. Bisogna aver pazienza. Si semina, come fa Il contadino; e bisogna aspettare per raccogliere." (CARNELUTTI, Francesco, Diritto e processo, cit., p. 154).

486 DINAMARCO, Cândido Rangel. Mandado de segurança. Execução provisória. Revista dos Tribunais, São Paulo, v. 70, n. 543, p. 26, jan. 1981.

${ }^{487}$ HARTLEY, Trevor C., How to abuse the law and (maybe) come out on top: bad-faith proceedings under the Brussels jurisdiction and judgments conventions, cit., p. 143.

${ }^{488}$ Corte di Cassazione, 19.12.2003, BL Macchine v. Windmoeller \& Holscher (STANKO, Andrej, Cross border "torpedo" litigation, cit.).
} 
afastou sua aplicação, que se refere à responsabilidade civil extracontratual, não podendo ser invocada em ações declaratórias.

Como na Itália, os tribunais belgas abordaram a questão do abuso processual nos casos de violação de patentes nos casos Röhm Enzima ${ }^{489}$ e Roche ${ }^{490}$, em 2000. Em ambos os casos, os tribunais belgas consideraram-se incompetentes para julgar as ações declaratórias de não violação das patentes.

O Tribunal Distrital de Paris também proferiu diversas decisões contrárias ao trâmite dos torpedos em seu território. No caso Banco Santander, de 28 de abril de 2000, o Tribunal Distrital de Paris ${ }^{491}$ julgou que uma ação em que se pretendia a declaração de inexistência de infração transnacional de uma patente, proposta em um tribunal italiano, não era conexa a uma ação condenatória proposta por uma parte francesa na França. O tribunal francês considerou que a ação condenatória francesa e a ação declaratória italiana não tinham a mesma causa de pedir ${ }^{492}$. Evidentemente, trata-se de uma interpretação muito controvertida do conceito de causa de pedir.

Muito embora os torpedos continuem sendo utilizados em larga escala, principalmente na Itália e na Bélgica, existem alguns movimentos jurisprudenciais visando a diminuir sua incidência.

Outro ponto importante foi a criação de um sistema paneuropeu de patentes, em 11.12.2012, pelo Parlamento Europeu. O Parlamento aprovou as três propostas: o Regulamento n. 1.257/2012 sobre uma patente europeia com efeito unitário (PEEU), o regime linguístico e a formação de um novo sistema judicial unificado de patentes (Tribunal Unificado de Patentes). A Itália e a Espanha recusaram-se a participar do novo sistema, porque os idiomas oficiais do novo sistema europeu serão o inglês, o alemão e o

${ }^{489}$ Brussels District Court, 12.05.2000, Röhm Enzyme GmbH v. DSM (STANKO, Andrej, Cross border "torpedo" litigation, cit.).

${ }^{490}$ Brussels District Court, 08.06. 2000, NV Roche v. The Wellcome Found. Ltd. (STANKO, Andrej, op. cit.).

${ }^{491}$ Paris District Court, 28.04.2000, Banco Santander v. Kortex International and Agro Informatica y Communicaciones (EISENGRAEBER, Julia, Lis alibi pendens under the Brussels I Regulation: how to minimise 'torpedo litigation' and other unwanted effects of the 'first-come, first-served' rule, cit.).

${ }^{492}$ VÉRON, Pierre. Italian torpedoes: an endangered weapon in french courts? International Review of Industrial Property and Copyright Law IIC, Munich, v. 33, No. 2, p. 230, 2002. Parece evidente que a causa de pedir de ambas as demandas - declaratória e condenatória - refere-se ao potencial descumprimento dos direitos de uma patente. 
francês, e a Polônia e a Espanha não assinaram o acordo referente ao Tribunal Unificado, embora possam se juntar a qualquer momento. $\mathrm{O}$ acordo internacional para a criação do tribunal entrará em vigor após treze Estados o terem ratificado, desde que o Reino Unido, França e Alemanha estejam entre eles ${ }^{493}$. Até o momento, seis países ratificaram o acordo, dentre eles a França. ${ }^{494}$

O Regulamento (EU) n. 1.257/2012, portanto, indica que todas as questões serão julgadas num único tribunal europeu centralizado, cuja especificação está contida no Acordo relativo ao Tribunal Unificado de Patentes (2013/C 175/01). Com sede em Paris, e seções em Munique e Londres, o tribunal também terá “divisões locais" nos Estados membros (art. $7^{\circ}$ do Acordo).

Embora não esteja ainda instalado, esse futuro tribunal não parece afastar o risco do forum shopping e novos torpedos, na medida que as ações deverão ser intentadas perante a divisão local acolhida pelo Estado membro contratante “onde ocorreu ou poderá vir a ocorrer a violação, onde o demandado reside ou possui um estabelecimento ou a divisão regional em que esse Estado membro contratante participa" (art. 33).

Em tese, uma parte infratora poderá continuar propondo suas ações declaratórias torpedo em jurisdições em que se sentir ameaçada pela suspensão de suas atividades comerciais.

Do ponto de vista processual, muito embora a criação de cortes de primeira instância especializadas em patentes possa acelerar o trâmite das decisões, é possível que o uso do torpedo ainda seja possível, como forma de impedir a propositura das ações condenatórias, a não ser na hipótese de reconvenções, o que em princípio não afasta o problema das jurisdições mais lentas.

\footnotetext{
493 Parliament approves EU unitary patent rules. Disponível em: <http://www.europarl.europa.eu/news/en/news-room/content/20121210IPR04506/html/Parliamentapproves-EU-unitary-patent-rules>. Acesso em: 30 out. 2013.

494 Patente Europeia com Efeito Unitário, relatório da Deloitte Consultores S/A. para a Confederação Empresarial de Portugal (CIP), janeiro de 2015.
} 


\subsection{O libel tourism inglês: defamation laws e liberdade de expressão}

Libel tourism é uma modalidade de forum shopping em que demandantes nacionais ou estrangeiros escolhem uma jurisdição para a propositura de ação de indenização em face de réus nacionais ou estrangeiros, sob a alegação de terem sofrido uma ofensa à sua honra (calúnia, injúria ou difamação ${ }^{495}$ ).

O critério para a escolha da jurisdição leva em conta a existência de leis materiais no foro menos favoráveis à liberdade de expressão do que às da jurisdição em que normalmente o réu é domiciliado ${ }^{496}$. Após a prolação da sentença, o autor busca a satisfação de seu crédito, materializado em uma sentença estrangeira, na jurisdição em que o réu é domiciliado ou onde ele tenha patrimônio. ${ }^{497}$

Trata-se de um forum shopping de primeiro grau, pois o demandante busca a incidência específica das regras de direito internacional privado do foro. Em se tratando de ofensa à honra, via de regra, aplica-se a lei do local em que o ilícito tenha sido cometido (lex loci delicti commissi $)^{498}$. Porém, nos casos de danos à honra cometidos pela internet, o

\footnotetext{
495 “ Os crimes contra a honra estão previstos no Código Penal brasileiro entre os artigos 138 a 145. Nos casos da calúnia e da difamação, as penas são compostas por privação de liberdade e multa, enquanto na injúria, varia entre o encarceramento ou o pagamento da multa. A calúnia é aduzida no momento em que alguém realiza uma imputação falsa de um fato definido como crime praticado por outrem. Dessa forma, para se caracterizar a calúnia, a) um fato deve ser imputado, b) esse fato deve ser considerado um crime e c) o fato deve ser, obrigatoriamente, falso. Há, portanto, elementos objetivos e subjetivos, sendo o primeiro a imputação do fato criminoso e o segundo a intenção de caluniar, o animus caluniandi. A difamação, por sua vez, é configurada quando fatos determinados, sejam falsos ou verdadeiros, são imputados à outra pessoa com a finalidade de macular sua honra objetiva, ou seja, sua reputação. Diferentemente do que ocorre com a calúnia, não se exige que o fato imputado pela difamação seja falso. Por último, a injúria, ao contrário da calúnia e da difamação, visa proteger a honra subjetiva que o agente tem de si mesmo. Imputa-se, dessa forma, uma qualidade negativa, atributos pejorativos à pessoa do agente. É prevista, também, a injúria qualificada, disposta no art. $140, \S 3^{\circ}$, que versa: 'se a injúria consiste na utilização de elementos referentes a raça, cor, etnia, religião, origem ou a condição de pessoa idosa ou portadora de deficiência: Pena reclusão de um a três anos e multa.'." (SILVA, Alexandre Assunção e. Liberdade de expressão e crimes de opinião. São Paulo: Atlas, 2012. p. 152).

${ }^{496}$ GERNY, Marissa. The SPEECH act defends the First Amendment: a visible and targeted response to libel tourism. Seton Hall Legislative Journal, v. 36, No. 2, p. 410, 2012; ROBINSON, Darren J. U.S. enforcement of foreign judgments, libel tourism and de SPEECH Act: protecting speech or discouraging foreign legal cooperation? Transnational Law \& Contemporary Problems, v. 21, p. 911, 2012-2013.

497 MELKONIAN, Harry. Defamation, libel tourism and the SPEECH Act of 2010. Amherst, NY: Cambria Press, 2010. p. 15; e BROWER, Amy J. (Ed.). Libel tourism and foreign libel lawsuits. Hauppauge, NY: Nova Science, 2011. p. 14.

498 TENÓRIO, Oscar, Lei de Introdução ao Código Civil brasileiro, cit., p. 331; STRENGER, Irineu, Direito internacional privado, cit., p. 431; e BASSO, Maristela, Curso de direito internacional privado, cit., p. 178.
} 
prejuízo pode ser causado em outras jurisdições, constituindo-se a obrigação de reparar no local da ocorrência do dano, e não no local onde o ilícito foi praticado.

Com os avanços da internet, opiniões ou documentos disponibilizados na rede mundial de computadores têm o potencial de serem acessados por usuários situados na maioria dos países do mundo. Como consequência, um libel plaintiff (ou demandante de uma ação de indenização por ato contra a honra) pode optar por propor sua demanda em qualquer jurisdição, mesmo que a publicação originária tenha sido disponibilizada em seu próprio Estado de residência que, muitas vezes, não tem leis materiais tão severas contra os ilícios de opinião, como o Estado do foro em que a ação será proposta.

Para exemplificar, será tratado a seguir o tema do libel tourism ante as jurisprudências do Reino Unido (local preferido para a propositura de ações indenizatórias por crimes contra a honra) e dos Estados Unidos (onde a Constituição americana protege a liberdade de opinião e de expressão em níveis muito elevados), já que houve um grande embate sobre o assunto.

Nos Estados Unidos prevalece uma ampla proteção ao direito de opinião, garantido pela Primeira Emenda à Constituição dos Estados Unidos. ${ }^{499}$

A proteção constitucional do direito de opinião nos Estados Unidos é tida como um "local sagrado na sociedade" 500 . A doutrina norte-americana considera que a liberdade de expressão "assegura a livre troca de ideias, que permitem as mudanças políticas e sociais desejadas pelo povo"501, garantindo a liberdade de expressão "sem medo de persecução por parte do governo", embora haja restrições a casos de atos ilícitos dolosos ${ }^{502}$. Já a liberdade jornalística está contida no princípio do "quarto poder", pelo qual se entende a imprensa livre como uma fiscalização necessária (e irrestrita) sobre os atos do governo, mantendo a

\footnotetext{
499 "Amendment I. Congress shall make no law respecting an establishment of religion, or prohibiting the free exercise thereof; or abridging the freedom of speech, or of the press; or the right of the people peaceably to assemble, and to petition the government for a redress of grievances."

${ }^{500}$ MALY, Heather. Publish at Your own risk or don't publish at all: forum shopping trends in libel litigation leave the first amendment un-guaranteed. Journal of Law and Policy, v. 14, p. 889, 2006.

${ }^{501}$ GERNY, Marissa, The SPEECH act defends the First Amendment: a visible and targeted response to libel tourism, cit., p. 414.

${ }^{502}$ STURTEVANT, Tara. Can the United States talk the talk \& walk the walk when it comes to libel tourism: how the freedom to sue abroad can kill the freedom of speech at home. Pace International Law Review, v. 22, p. 269, 2010.
} 
opinião pública informada, o que demanda proteção máxima do Estado ${ }^{503}$. No caso New York Times $v$. Sullivan, a Suprema Corte americana interpretou que a Primeira Emenda era "um compromisso nacional concreto com o princípio de que o debate sobre assuntos de interesse coletivo devem ser irrestritos, aprofundados e amplos, podendo se manifestar de forma veemente, cáustica, e às vezes desagradavelmente afiada ante ao governo ou servidores públicos" ${ }^{, 504}$. Para afastar a proteção constitucional, o autor deve provar que o réu agiu com "malícia inequívoca”, pois sabia que a notícia era falsa. ${ }^{505}$

Por outro lado, o Reino Unido é frequentemente referido como a "capital mundial da difamação" 506 , por ser "o mais atrativo destino para o libel tourists no globo"507. O direito à honra e à imagem limitam o direito à liberdade de expressão, inclusive, com possível sanções penais (como no Brasil), enquanto nos Estados Unidos o dano à imagem é considerado uma consequência inevitável da liberdade de expressão. ${ }^{508}$

Em síntese, no Reino Unido, qualquer menção, notícia ou declaração que possa afetar a reputação de uma pessoa é, prima facie, difamatória, ao contrário do que ocorre nos Estados Unidos. O ônus da prova é transferido do autor (ofendido) ao réu (ofensor), pois havendo a presunção de que houve dano à honra, este último deve provar que a menção, notícia ou declaração prestada era verdadeira. Os únicos requisitos impostos ao autor são: (a) que a manifestação difamatória foi endereçada a ele; (b) que ela foi executada pelo réu; e (c) que o conteúdo da mensagem teve um conteúdo ofensivo à honra. $^{509}$

${ }^{503}$ GERNY, Marissa, The SPEECH act defends the First Amendment: a visible and targeted response to libel tourism, cit., p. 415.

${ }^{504}$ Caso New York Times v. Sullivan, 376 U.S. 254, 256-58, 270 (1964). Nesse caso, um comissário de polícia da cidade de Montgomery, Alabama, propôs uma ação de difamação contra o jornal e quatro religiosos negros, por conta de um anúncio publicado no jornal. Nesse anúncio, era mostrado um grupo de brancos protestando contra as manifestações de negros por direitos civis, que estavam acontecendo no Sul do país no início dos anos 60.

${ }^{505}$ GERNY, Marissa, op. cit., p. 415.

${ }^{506}$ RUSBRIDGER, Alan. How to stifle the press: England has become the world capital of libel. With a few tricks and a good lawyer, anyone can cover up an inconvenient truth. Spectator, 18 Sept. 2010.

${ }^{507}$ GERNY, Marissa, op. cit., p. 416.

${ }^{508}$ Conforme decidido pela Suprema Corte, no caso New York Times $v$. Sullivan.

${ }^{509}$ MOORE, Todd W. Untying our hands: the case for uniform personal jurisdiction over "libel tourists". Fordham Law Review, v. 77, p. 3.207, 2009. As cortes inglesas afastam a exigência do ônus da prova pelo réu, em casos considerados de grande importância para a opinião pública, e desde que os comentários tenham sido equilibrados (fair comments), sendo essa exceção aplicada quando a mensagem fôr de interesse público. Do mesmo modo, as manifestações emanadas dos membros do parlamento são imunes a processos. Por fim, a imprensa goza desse privilégio, "for fair and accurate reporting on judicial proceedings". (GERNY, Marissa, GERNY, Marissa, op. cit., p. 418). 
Outra diferença importante é o prazo de prescrição para que o ofendido proponha sua ação indenizatória. Enquanto o termo legal, nos Estados Unidos, inicia com a primeira publicação da mensagem (mesmo que ela continue exposta na internet durante gerações), no Reino Unido, entretanto, a prescrição inicia somente quando a mensagem não estiver mais disponível, quer seja de forma impressa ou online. ${ }^{510}$

Também diferem as regras dos Estados Unidos e do Reino Unido quanto à quantidade de demandas que podem ser propostas pelo ofendido, na hipótese de haver diversas publicações da matéria sub judice, em diversas jurisdições. A maioria dos Estados americanos segue a single publication rule, pela qual não importa em quantas jurisdições a mensagem difamatória foi divulgada, seja ela escrita, televisiva, radiofônica ou online, o autor pode somente propor uma única ação reparatória em face do ofensor. Ocorrendo o evento danoso em diversas mídias, o prazo de prescrição inicia a partir do momento em que ele foi divulgado pela primeira vez ${ }^{511}$. No Reino Unido, utiliza-se da chamada multiple publication rule, pela qual o demandado pode ser acionado em qualquer jurisdição em que mensagem danosa tenha sido publicada. A origem dessa regra é o caso The Duke of Brunswich $v$. Harmer, julgado em 1849, em que a compra de um único exemplar de um jornal datado de dezessete anos atrás motivou uma nova condenação do réu por difamação. A regra oriunda desse precedente tem sido aplicada, atualmente, para as publicações divulgadas na internet, o que permitiu a construção de uma jurisdição internacional das cortes inglesas para julgarem demandas movidas entre estrangeiros, pela alegação de que a matéria foi acessada a partir de computadores do Reino Unido, graças à internet. ${ }^{512}$

Outra diferença decorre dos custos judiciais. Enquanto nos Estados Unidos os litigantes dividem as custas e despesas, cada qual arcando com aquelas a que deram causa, inclusive dos honorários de seus advogados, no Reino Unido a parte vencida deve reembolsar todos os gastos incorridos pela parte vencedora (ônus da sucumbência, como no Brasil). Segundo Marissa Gerny, não raramente, os custos de um litigio envolvendo libel cases na Inglaterra pode custar milhões de dólares. ${ }^{513}$

\footnotetext{
${ }^{510}$ GERNY, Marissa, The SPEECH act defends the First Amendment: a visible and targeted response to libel tourism, cit., p. 423.

${ }^{511}$ Restatement (second of torts) $\$ 577 \mathrm{~A}(3)$ (1977) e 577A(4)(b).

512 STAVELEY-O'CARROLL, Sarah, Libel tourism laws: spoiling the holiday ad saving the First Amendment?, cit., p. 261.

${ }^{513}$ GERNY, Marissa, op. cit., p. 425.
} 
Enquanto o Reino Unido ainda detém o posto de libel capital do mundo, outros países começaram a atrair libel tourists. Como os Estados Unidos, as raízes jurídicas da Austrália derivam do common law inglesa; porém, enquanto os Estados Unidos se desviaram das regras antidifamação inglesas, a Austrália seguiu a mesma tradição. ${ }^{514}$

Segundo a doutrina, as diferenças jurídicas entre ambos os ordenamentos (americano e inglês) tornaram-se notórios a partir de 1996, quando o historiador inglês David Irving propôs em Londres uma ação de indenização em face da americana Deborah Lipstadt, professora da Universidade de Emory, no Texas, pelo fato de esta última ter acusado o primeiro de ser um "negador do Holocausto". Esse caso teve uma ampla repercussão na mídia internacional, ao revelar a diferença jurídica entre ambas as jurisdições. Após cinco anos, a ação foi julgada improcedente, porém a um alto custo à ré. $^{515}$

Em 1997, o russo Boris Berezovsky (já referido neste trabalho em outro caso, ver item 1.4.2.2) propôs uma ação em Londres em face da revista novaiorquina Forbes ${ }^{516}$, pela reportagem denominada "Godfather of the Kremlin? Power. Politics. Murder. Boris Berezovsky could teach the guys in Sicily a thing or two", escrita pelo jornalista russoamericano Paul Kiebnikov, que por sua vez acusava Berezovsky de tráfico de influência junto ao presidente da Rússia na época, Boris Yeltsin, dentre outros muitos atos ilícitos ${ }^{517}$. A corte inglesa, não obstante a defesa da revista, não aplicou a doutrina do forum non conveniens, considerando que a matéria havia circulado nas bancas inglesas e, portanto, era passível de ter causado danos à imagem do autor ${ }^{518}$. As partes encerraram o caso por meio de um acordo, em 2003, por meio do qual a Forbes apresentou uma retratação parcial quanto à matéria publicada.

\footnotetext{
${ }^{514}$ STURTEVANT, Tara, Can the United States talk the talk \& walk the walk when it comes to libel tourism: how the freedom to sue abroad can kill the freedom of speech at home, cit., p. 281.

${ }^{515}$ GERNY, Marissa, The SPEECH act defends the First Amendment: a visible and targeted response to libel tourism, cit., p. 411. Ver The New York Times, 22 July 2000. Disponível em: <http://www.nytimes.com/2000/07/22/arts/where-suing-for-libel-national-specialty-britain-s-plaintifffriendly-laws-have.html>. Acesso em: 21 maio 2015.

${ }^{516}$ Caso Berezovsky v. Michaels and Others, (House of Lords), [2000] 1, W.L.R. 1004, 1008-09.

517 FORBES, 30 Dec. 1996. Disponível em: <http://www.forbes.com/forbes/1996/1230/5815090a.html>. Acesso em: 16 maio 2015.

${ }^{518}$ GERNY, Marissa, op. cit., p. 412.
} 
A partir do desenvolvimento da internet, a Inglaterra acabou sendo escolhida por políticos e empresários para a propositura de suas ações de indenização por dano à honra e à imagem contra jornalistas do mundo inteiro. O mais notório exemplo de libel tourism foi o caso Ehrenfeld v. Mahfouz ${ }^{519}$. Em 2002, o conglomerado financeiro Bank of Credit and Commerce Internacional (BCCI) foi condenado pela Justiça de Nova York por lavagem de dinheiro, suborno, apoio ao terrorismo, tráfico de drogas e uma série de outros crimes ${ }^{520}$. Seu diretor, Khalid Salim Bin Mahfouz, bilionário saudita e considerado o mais notório libel tourist das cortes inglesas ${ }^{521}$, foi acusado pessoalmente de fraude pelo grande júri de Nova York. Ele acabou firmando um acordo e pagando US\$ 225 milhões de multa, sem assunção de culpa. $^{522}$

Visando a proteger sua reputação, Mahfouz ingressou com vinte e nove ações reparatórias no Reino Unido, sempre na qualidade de libel tourist. Ele criou um site pessoal, em que estão publicadas cinquenta "erratas" que foram determinadas pelas cortes inglesas, e publicadas em revistas, jornais, sites e até mesmo livros, em quatro países, de 2002 até 2009 (ano de sua morte) ${ }^{523}$. Dentre os jornalistas, editores, periódicos e escritores processados por Mahfouz, estava a autora americana Rachel Ehrenfeld, autora do livro "Funding evil: how terrorism is financed - and how to stop it". Nessa obra, Ehrenfeld acusou a família Mahfouz de financiar as atividades terroristas, tendo vendido vinte e três exemplares no Reino Unido. Processada na Inglaterra por Mahfouz ${ }^{524}$, a ação foi julgada procedente à revelia e Ehrenfeld condenada ao pagamento de 200 mil libras esterlinas. Com o propósito de evitar a execução da futura sentença estrangeira (inglesa) em seu domicílio nos Estados Unidos, Ehrenfeld, por meio de um forum shopping reverso, propôs uma ação declaratória em face de Mahfouz em Nova York. O objeto dessa nova demanda

${ }^{519}$ Caso Ehrenfeld v. Mahfouz, 518 F.3d 102 (2d Cir. 2008); Bin Mahfouz v. Ehrenfeld, [2005] EWHC (QB) 1156.

${ }^{520}$ KERRY, John; BROWN, Hank. The BCCI affair: a report to the Committee on Foreign Relations United States Senate, Senate Print No. 102-140, December 1992, 102d Congress, 2nd Session. Disponível em: <https://info.publicintelligence.net/The-BCCI-Affair.pdf>. Acesso em: 15 maio 2015.

${ }^{521}$ ROBINSON, Darren J. U.S. enforcement of foreign judgments, libel tourism and de SPEECH Act: protecting speech or discouraging foreign legal cooperation?, cit., p. 911.

${ }^{522}$ VARDI, Nathan. The world's billionaires: sins of the father?. Forbes, 18 March 2002. Disponível em: <http://www.forbes.com/global/2002/0318/047.html>. Acesso em: 16 maio 2015.

523 O site se chama "Bin Mahfouz Information" e possui nada menos que cinquenta corrections (ou "erratas"), além de pedidos de desculpas e assunção de falta de cuidados nas publicações, emitidas por uma série de jornalistas, escritores e órgãos de imprensa, tais como: The Washingtont Post; The Wall Street Journal; Euromoney; Los Angeles Times; Penguin Books; USA Today; L'Humanité; The Times; Cambridge University Press; The Guardian, dentre outros. Disponível em: <http://www.binmahfouz.info/>. Acesso em: 16 maio 2015.

${ }^{524}$ Caso Bin Mahfouz v. Ehrenfeld, [2005] EWHC (QB) 1156. 
era a declaração de que a sentença estrangeira não seria eficaz nos Estados Unidos, pois violaria a Primeira Emenda ${ }^{525}$. A corte de Nova York indeferiu a ação declaratória em 2007, por não haver o "mínimo contato" entre as atividades de Mahfouz e o foro que pudesse justificar a competência internacional da Justiça americana. Esse caso causou uma grande comoção nos Estados Unidos. ${ }^{526}$

Motivado pelo caso Ehrenfeld, o Estado de Nova York promulgou em 2009 a norma denominada Libel Tourism Protection Act, conhecida como Rachel's Law. Essa norma prevê que sentenças estrangeiras condenatórias, baseadas em dano à honra (defamations judgment), não serão executadas pelas cortes de Nova York, a não ser que os juízes americanos considerem que as leis materiais aplicadas no exterior protegeram a liberdade de expressão e de imprensa do réu, como seriam protegidas pelas Constituições dos Estados Unidos e do Estado de Nova York. ${ }^{527}$

Após, outros Estados americanos promulgaram leis assemelhadas, tais como Illinois, em 2008, Califórnia e Flórida, em 2009. Em 2013, o governo federal americano promulgou o SPEECH Act ${ }^{528}$, cujo objeto é proibir o reconhecimento e a execução de sentenças estrangeiras pelas cortes americanas, baseadas em defamation lawsuits, movidas em face de autores, editores e provedores de conteúdo de internet nos Estados Unidos. ${ }^{529}$

Finalmente, em 2013, a Inglaterra e o País de Gales promulgaram o Defamation Act 2013, criando novos requisitos para o libel tourism: em primeiro lugar, os demandantes estrangeiros devem demonstrar que as cortes inglesas são mais apropriadas para julgar a demanda; em segundo lugar, o dano à reputação deve ser demonstrado pelo

\footnotetext{
${ }^{525}$ Caso Ehrenfeld v. Mahfouz, 518 F.3d 102, 103-04 (2d Cir. 2008).

${ }^{526}$ FELDMAN, Michelle. Putting the brakes on libel tourism: examining the effects tests as a basis for personal jurisdiction under NewYork's Libel Terrorism Protection Act. Cardozo Law Review, v. 31, p. 6, 2010.

${ }^{527}$ MELKONIAN, Harry, Defamation, libel tourism and the SPEECH Act of 2010, cit., p. 241; BROWER, Amy J. (Ed.), Libel tourism and foreign libel lawsuits, cit., p. 27. "Since virtually "no other jurisdiction provides as high a level of protection for speech as the United States', the Act disables almost every foreign defamation judgment." (STAVELEY-O'CARROLL, Sarah, Libel tourism laws: spoiling the holiday ad saving the First Amendment?, cit., p. 276).

${ }^{528}$ Securing the Protection of our Enduring and Established Constitutional Heritage Act (SPEECH Act). Essa lei foi aprovada por unanimidade na Câmara dos Deputados e no Senado Federal, a sancionada pelo presidente Barak Obama em 2013.

${ }^{529}$ GERNY, Marissa, The SPEECH act defends the First Amendment: a visible and targeted response to libel tourism, cit., p. 435.
} 
demandante; em terceiro lugar, considera-se que a divulgação é sempre feita de boa-fé, e no melhor interesse público, deixando a cargo do demandante provar o contrário. ${ }^{530}$

\subsection{Anti-suit injunctions}

A anti-suit injuction é uma tutela judicial inibitória, concedida a requerimento do autor, para que o réu não inicie ou interrompa outra ação judicial ou arbitragem já iniciada no estrangeiro. Surgida no direito inglês, essa tutela é endereçada à parte e não ao Estado estrangeiro ou à corte arbitral. ${ }^{531}$

Por pretender regular o comportamento processual do litigante em outras jurisdições, essa medida é considerada "o mais interessante e controvertido" instrumento dos litígios internacionais ${ }^{532}$ ou ainda "o mais poderoso remédio processual disponível nas cortes inglesas" para os conflitos de jurisdição. ${ }^{533}$

A parte que não atender a uma injuction incorre em uma contempt of court (desobediência judicial ou desacato à autoridade). No direito inglês, há dois tipos de contempt of court: criminais (criminal contempt) e cíveis (civil contempt). ${ }^{534}$

Constituem criminal contempts as infrações (offenses) de natureza pública, que interferem no andamento do processo, tais como: influenciar testemunhas; interromper o procedimento com atos, palavras ou condutas; tentar obstaculizar atos de autoridade; impedir os atos da parte contrária; ou se negar a responder perguntas durante um depoimento judicial. ${ }^{535}$

Já a civil contempt (também chamada procedural contempt) se aplica às infrações de natureza privada, em que uma parte impede a outra de gozar de um benefício obtido

\footnotetext{
${ }^{530}$ MULLIS, Alastair; SCOTT, Andrew. Tilting at windmills: the Defamation Act 2013. The Modern Law Review, v. 77, p. 88, 2014.

${ }^{531}$ RAPHAEL, Thomas. The anti-suit injuction. Oxford: Oxford University Press, 2008. p. 4.

532 BERMANN, George A. The use of anti-suit injunctions in international litigation. Columbia Journal of Transnational Law, v. 28, p. 589, 1990.

533 AMBROSE, Clare. Can anti-suit injunctions survive European community law? International and Comparative Law Quarterly, v. 52, No. 2, p 401, 2003.

${ }^{534}$ REQUEJO ISIDRO, Marta. Proceso en el extranjero y medidas antiproceso: (antisuit injunctions). Santiago de Compostela: Servicio de Publicacións da Universidade de Santiago de Compostela, 2000. p. 77.

${ }^{535}$ HARNON, Eliahu. Civil and criminal contempts of court. The Modern Law Review, v. 25, p. 187, 1962.
} 
judicialmente. Ou seja, a parte comete uma civil contempt ao ignorar uma specific performance (uma obrigação de fazer ou de não fazer, determinada pela corte) ou agindo de modo contrário a uma injunction (medida acautelatória ou antecipada) ${ }^{536}$. Dessa maneira, a desobediência a uma anti-suit injuction é considerada uma civil contempt of court, cuja consequência é a aplicação de medidas coercitivas pela autoridade em face da parte infratora, tais como a prisão, multa e o sequestro de bens. No caso de a parte infratora não residir ou não possuir bens no foro, as penalidades podem ser processuais, tais como a proibição de ser ouvida em juízo, de interpor recurso ou mesmo de chamar testemunhas residentes no foro para deporem no estrangeiro. ${ }^{537}$

Esse tipo de tutela jurisdicional tem sido aplicado na Escócia e nos Estados Unidos, assim como em países do civil law, como a Holanda, Québec e, em pelo menos um caso, na França. Também há casos com a mesma natureza, mas com outra denominação, na Bélgica e na Alemanha. ${ }^{538}$

Inclusive, o próprio Brasil também reforça tal estatística, com sua própria anti-suit injuction. Em 2011, durante a construção da Usina do Jirau, em Rondônia ${ }^{539}$, uma greve de operários levou a uma série de incidentes no canteiro de obras, em que diversas instalações pertencentes às empreiteiras foram incendidas. Acionadas as companhias seguradoras, não houve acordo sobre as causas do acidente e o valor envolvido. Por conta disso, as empreiteiras propuseram uma ação de indenização contra as seguradoras em São Paulo, baseadas na eleição de foro constante do contrato. Quase ao mesmo tempo, as seguradoras requereram a instalação de um tribunal arbitral, em Londres, baseadas na cláusula de compromisso arbitral existente na apólice de seguros. Visando a evitar "julgamentos conflitantes", o Tribunal de Justiça de São Paulo deferiu em 2012 a liminar requerida em agravo de instrumento pelas empreiteiras, ordenando que as seguradoras se abstivessem de prosseguir com a arbitragem londrina, sob pena de multa diária de quatrocentos mil

${ }^{536}$ RENDLEMAN, Doug. Complex litigation: injuctions, structural remedies and contempt, supplement: procedural rules, statutes, court documents. New York: Foundation Press, 2009. p. 52.

537 REQUEJO ISIDRO, Marta Requejo, Proceso en el extranjero y medidas antiprocesso (anti-suit injunctions), cit., p. 78; MCGHEE, John; SNELL, Edmund Henry Turner. Snell's equity. London: Sweet \& Maxwell, 2000, p. 675; MARGIT, Livingston. Disobedience and contempt (civil and criminal contempt of court). Washington Law Review, v. 75, p. 349, 2000; e CHESTERMAN, Michael. Contempt: in the common law, but not the civil law. International and Comparative Law Quarterly, v. 46, p. 524, 1997.

${ }^{538}$ RAPHAEL, Thomas, The anti-suit injuction, cit., p. 2, nota 2.

539 Para maior compreensão do caso, vide: COSTA, José Augusto Fontoura. A vontade e a forma: a percepção da arbitragem no caso do contrato de seguro do Projeto Jirau. Revista de Arbitragem e Mediação, São Paulo, Revista dos Tribunais, v. 10, n. 38, p. 35-60, jul./set. 2013. 
reais $^{540}$. O curioso é que semanas antes, a England and Wales Court of Appeal havia deferido uma anti-suit injuction requerida pelas seguradoras, determinando que as empreiteiras brasileiras se abstivessem de prosseguir com sua demanda judicial no Brasil $^{541}$. Em resumo, ambas as partes tiveram deferido contra si, e ao mesmo tempo, antisuit injuctions da Inglaterra e do Brasil, obrigando-as a desistir de procedimentos iniciados por elas em ambas as jurisdições, num evidente paradoxo. ${ }^{542}$

$\mathrm{O}$ instituto da anti-suit injuction teve origem no direito processual inglês, como forma de evitar que os litigantes manipulassem o julgamento dos litígios dentro da própria jurisdição inglesa. Até a fusão do sistema jurídico inglês (que era bipartido) pelos Supreme Court of Judicature Acts de 1873 e 1874, havia a possibilidade de os litígios serem simultaneamente propostos, pelo mesmo litigante, tanto na Court of Chancery, sediada em Londres, como nas cortes locais que aplicavam o common law. Esse forum shopping doméstico era remediado com a medida denominada common injunction, desde o século $\mathrm{XV}$, cujo propósito era o de evitar os procedimentos paralelos dentro do Reino Unido ${ }^{543}$. A partir do século XVIII, a jurisprudência inglesa começou a deferir liminares inibitórias contra as partes que propunham litígios conexos ou litispendentes no exterior ${ }^{544}$. Inicialmente, as ordens judiciais eram deferidas contra as partes que propunham processos na Escócia, Irlanda e nas colônias britânicas ${ }^{545}$. Atualmente, as cortes inglesas aplicam o instituto de forma ampla, isto é, pela existência de processos movidos fora da Commonwealth, desde que estejam presentes os requisitos necessários exigidos pela corte

\footnotetext{
${ }^{540}$ TJSP - AI n. 0304979-49.2011.8.26.000.

${ }^{541}$ Caso Sulamerica Cia Nacional de Seguros SA v. Enesa Engenharia S.A.

${ }^{542} \mathrm{O}$ paradoxo é que ambos os polos processuais não tinham condições de cumprir a ordem judicial proferida por uma corte, sem violar a decisão proferida pela outra, num manifesto conflito de jurisdições. A situação pode ser comparada à imagem do cinema americano de bang-bang denominada mexican standoff: "A Mexican standoff is a confrontation between two or more parties in which neither party can proceed nor retreat without being exposed to danger. As a result, all participants need to maintain the strategic tension, which remains unresolved until some outside event makes it possible to resolve it." (Disponível em: <http://en.wikipedia.org/wiki/Mexican_standoff>. Acesso em: 24 maio 2015).

${ }^{543}$ RAPHAEL, Thomas, The anti-suit injuction, cit., p. 41.

${ }^{544}$ HARTLEY, Trevor C. Comity and the use of anti-suit injunctions in international litigation. American Journal of Comparative Law, v. 35, n. 3, p. 490, 1987. A common injunction foi abolida pelo Judicature Act de 1873, restando a possibilidade de se deferirem liminares apenas quando em trâmite no exterior.

${ }^{545} \mathrm{O}$ caso mais emblemático, segundo a doutrina inglesa, é o caso Lord Portarlington $v$. Soulby (1834) $3 \mathrm{My}$ \& K. 104, 40 Eng. Rep. 40. Lord Portalington perdeu mil libras esterlinas e emitiu uma letra de câmbio como garantia do pagamento da dívida. O título acabou sendo endossado em favor de Soulby, que sabia a origem do crédito (dívida de jogo). Este último propôs uma ação de execução na Irlanda, porém Lord Portalington obteve uma anti-suit injuction contra Soulby, deferida por uma corte inglesa (HARTLEY, Trevor C., op. cit., p. 490).
} 
inglesa, isto é, que ela se considere a única competente para dirimir o litígio, não obstante opiniões em contrário de outras cortes estrangeiras. ${ }^{546}$

Os princípios gerais que regem as anti-suit injuctions na Inglaterra evoluíram de acordo com a adoção da doutrina do forum non conveniens. Como mencionado anteriormente, após o julgamento do caso The Atlantic Star pela House of Lords em 1974, a jurisprudência inglesa incorporou a doutrina escocesa do forum non conveniens, aplicando os requisitos (tests) que passaram a reger a competência internacional inglesa, e deixando de lado a análise do foro "vexatório ou opressivo". 547

Em 1981, no caso Castanho v. Root \& Brown ${ }^{548}$, a House of Lords adotou os requisitos da doutrina do forum non conveniens às anti-suit injuctions. Assim, nas hipóteses de conexão ou litispendência internacional, em que a corte inglesa considere que ela própria reúne as melhores condições para o julgamento do caso, as decisões inibitórias serão proferidas em face da parte que litigou no estrangeiro. ${ }^{549}$

Nas hipóteses em que a corte inglesa considerar que a jurisdição estrangeira é mais conveniente para apreciar o litígio, ela poderá decidir pela extinção do feito inglês ${ }^{550}$. Em resumo, as cortes inglesas se arvoraram na tarefa de decidir onde a demanda deve ser decidida, sem considerar a opinião das cortes estrangeiras.

Em 1986, com o julgamento do caso Spiliada Maritime Corp. v. Cansulex Ltda., conforme estudado anteriormente (ver item 2.3.2.2), deu-se o aperfeiçoamento da doutrina do forum non conveniens, com a maior autonomia do juiz inglês em deliberar sobre a competência internacional das cortes inglesas (discretion). ${ }^{551}$

Como dito, a nova compreensão da doutrina do forum non conveniens foi aplicada às anti-suit injuctions, que passaram a ser deferidas com maior disposição pelas partes inglesas ${ }^{552}$. Além das hipóteses de competência internacional concorrente, as cortes

\footnotetext{
${ }^{546}$ BERMANN, George A., The use of anti-suit injunctions in international litigation, cit., p. 592.

${ }^{547}$ JUENGER, Friedrich K., Forum shopping, domestic and international, cit., p. 865.

${ }^{548}$ Caso Castanho v. Root \& Brown, [1981] A.C. 557.

${ }^{549}$ BELL, Andrew S., Forum shopping and venue in transnational litigation, cit., p. 174.

${ }^{550}$ HARTLEY, Trevor C., Comity and the use of anti-suit injunctions in international litigation, cit., p. 491.

${ }^{551}$ BRAND, Ronald A.; JABLONSKI, Scott R. Forum non conveniens: history..., cit., p. 21.

${ }^{552}$ HARTLEY, Trevor C., op. cit., p. 494.
} 
inglesas também analisam os casos em que há obrigações contratuais firmadas entre as partes. A primeira hipótese é a existência de compromisso arbitral, a segunda, a existência de uma cláusula de eleição de foro, e finalmente, a terceira relaciona-se à aplicação de cláusulas contratuais específicas que vinculam as partes a certos procedimentos judiciais, como aquelas em que as partes se obrigam a não litigar. ${ }^{553}$

Nos Estados Unidos, as anti-suit injuctions foram analisadas pela Corte de Apelação do Distrito de Columbia, no caso Laker Airways v. Sabena, Belgian World Airlines. Nesse precedente, três foram os requisitos de admissibilidade estabelecidos pela corte: (a) proteger a autoridade da jurisdição local; (b) evitar a inutilidade de um procedimento estrangeiro, cuja futura sentença não poderá ser executada nos Estados Unidos, em função de alguma especificidade do caso concreto; e (c) se o processo estrangeiro foi iniciado depois de iniciado o processo do foro, numa espécie de prevenção do juízo. ${ }^{554}$

Uma diferença importante entre as anti-suit injuctions americanas e as inglesas é que as cortes dos Estados Unidos analisam os efeitos da sentença nacional no estrangeiro. Isto é, se a sentença norte-americana não puder resolver o litígio estrangeiro, a existência de processos em jurisdições concorrentes não é motivo para o deferimento de uma medida anti-suit. Exemplificando, nos casos envolvendo violação de patentes americanas em diversas jurisdições, uma sentença norte-americana não teria efeitos sobre uma violação ocorrida na Alemanha, de maneira que as cortes entendem tolerável a existência concomitante de litígios tanto nos Estados Unidos quanto no estrangeiro. ${ }^{555}$

Muito embora o TJUE tenha impedido as anti-suits injunctions inglesas no âmbito de processos judiciais movidos na União Europeia, conforme o já mencionado caso Turner v. Grovit, a doutrina considera possível seu deferimento no caso de arbitragens, haja vista

\footnotetext{
${ }^{553}$ BERMANN, George A., The use of anti-suit injunctions in international litigation, cit., p. 620. Exemplos dessa última hipótese são as cláusulas "estoppel in pais, promissory estoppel, election, waiver, standing by, laches and 'blowing hot and cold'." (HARTLEY, Trevor C., Comity and the use of anti-suit injunctions in international litigation, cit., p. 494).

${ }^{554}$ Caso Laker Airways v. Sabena, Belgian World Airlines, 731 F.2d 909 (D.C. Cir. 1984) (AMBROSE, Clare, Can anti-suit injunctions survive European community law?, cit., p. 418).

555 HARTLEY, Trevor C., op. cit., p. 496; UBERTAZZI, Benedetta. Intellectual property rights and exclusive (subject matter) jurisdiction: between private and public international law. Marquette I.P. Law Review, v. 15, p. 366, 2011.
} 
tais procedimentos estarem expressamente fora das hipóteses do Regime de BruxelasLugano. Do mesmo modo, ainda subsistem tais medidas quando as demandas que forem objeto das medidas inibitórias foram propostas fora da União Europeia. ${ }^{556}$

De uma forma geral, a doutrina internacional se divide quanto à abusividade ou não das anti-suit injuctions. Na Inglaterra, a posição doutrinária é que essas medidas, aliadas à doutrina do forum non conveniens, respondem melhor às hipóteses de litispendência e conexão internacionais do que as regras do first served rule do Regime de BruxelasLugano, impedindo a ocorrência dos "torpedos" 557 . Por outro lado, a doutrina continental considera as anti-suit injuctions como abusivas às partes e que tendem a violar a soberania de outros Estados. 558

O Instituto de Direito Internacional, em sessão de setembro de 2003, analisou o uso da doutrina do forum non conveniens e das anti-suit injunctions e emitiu uma resolução, concluindo que esses tipos de provimentos inibitórios violam o princípio da comity ${ }^{559}$. Da mesma maneira, a International Law Association, em sua $69^{\mathrm{a}}$ Conferência, realizada em julho de 2000, emitiu a Resolução n. 1/2000, em que recomendou que não fossem proferidas as anti-suit injuctions pelas cortes nacionais, a não ser que elas tenham a plena

\footnotetext{
${ }^{556}$ AMBROSE, Clare, Can anti-suit injunctions survive European community law?, cit., p. 418.

557 FRY, Taryn M. Injuction junction, what's your function? Resolving the split over anti-suit injuction deference in favor of international comity. Catholic University Law Review, v. 58, p. 1.073, 2008-2009.

${ }^{558}$ ELVIRA BENAYAS, María Jesús. ¿Existe alguna posibilitad, por pequeña que sea, de salvar lo nuestro? Las anti-suit injunction y el convenio de Bruselas. A propósito de la STJCE de 27 de abril de 2004 (C159/02). Revista Electrónica de Estudios Internacionales, v. 9, p. 4, 2005. Considerando o princípio da plenitudo jurisdiciones, que rege a competência internacional dos Estados, não é possível analisar as antisuits injuctions como uma possível afronta às decisões de outros Estados. Muito embora a jurisprudência analisada tenha mostrado uma prudência das cortes inglesas na análise de cabimento da medida e de sua própria competência, é importante se respeitar os possíveis entendimentos em contrário.

${ }^{559} \mathrm{O}$ texto do último parágrafo da resolução é o seguinte: "Les juridictions qui accordent des anti-suit injunctions devraient être sensibles aux exigences de la comity et, en particulier, ne devraient accorder de telles injonctions que lorsqu'il y a a) violation d'un accord relatif au choix du tribunal ou d'un accord d'arbitrage ; b) comportement déraisonnable ou oppressif d'un demandeur devant une juridiction étrangère ; ou c) nécessité de protection de leur propre compétence dans des matières telles que l'administration de biens et les procédures d'insolvabilité." (INSTITUT DE DROIT INTERNATIONAL. 2ème Commission. Session de Bruges. Resolution du 02.09.2003. Le recours à la doctrine du forum non conveniens et aux "anti-suit injunctions": principes directeurs. Disponível em: <http://www.idiiil.org/idiF/resolutionsF/2003_bru_01_fr.pdf >. Acesso em: 16 maio 2015). Leuven/London Principles on Declining and Referring Jurisdiction in Civil and Commercial Matters
} 
segurança de que a jurisdição estrangeira não seja a mais apropriada ao julgamento do litígio. $^{560}$

$\mathrm{Na}$ falta de uma regulação supranacional, parece evidente que que as anti-suit injunctions parecem violar a soberania de Estados terceiros, pelo simples fato de que as cortes que as emitem não têm o condão de ser a última palavra sobre a competência internacional global.

${ }^{560}$ A Resolução 1/2000 da International Law Association, elaborada curiosamente em Londres, contém os "Leuven/London Principles on Declining and Referring Jurisdiction in Civil and Commercial Matters". Diz a referida resolução: "Where there is no such applicable international convention, a court to which a request for such an injunction is made shall not grant an injunction where it is satisfied that these Principles will be applied by the court in which proceedings have been instituted." (INTERNATIONAL LAW ASSOCIATION. Resolution No. 1/2000. International Civil and Commercial Litigation. The 69th Conference of the International Law Association, held in London, United Kingdom, 25th-29th July 2000. Disponível em: 〈http://www.ila-hq.org/en/committees/index.cfm/cid/18>. Acesso em: 16 maio 2015). 


\section{CONCLUSÕES E O FUTURO DO FORUM SHOPPING}

O direito tornou-se um bem intercambiável. Até muito recentemente confinados em território nacional, os juízes passaram, desde há algum tempo, a estabelecer entre eles e através das fronteiras, relações cada vez mais sólidas e confiantes. No dizer de Allard e Garapon, essas relações podem tomar as formas mais diversas: referência a julgamentos estrangeiros em decisões de âmbito nacional, intercâmbio de argumentos, formações comuns, diálogos entre tribunais, criação de associações transnacionais, de clubes ou sindicatos de juízes, capitalizações informais de jurisprudência etc. ${ }^{561}$

A competência internacional é um dos temas mais relevantes do direito internacional privado atual $^{562}$. É possível que o centro de discussão da disciplina possa estar se alterando, dos problemas de direito aplicáveis, a problemas como a competência ${ }^{563}$, os efeitos das sentenças estrangeiras e a cooperação entre Estados distintos. ${ }^{564}$

Bernard Audit apontou um grande aumento nas questões relativas aos conflitos de jurisdição na atualidade, fazendo com que haja um salto entre o direito internacional privado acadêmico para o do mundo real: "La situation a changé du tout au tout avec le développement véritable des relations privées internationales au cours du XXe siècle, jusqu'à mettre aujourd'hui au premier plan les questions liées à l'administration par les juridctions des Etats de la justice internationale de droit privé, ${ }^{\text {565 }}$. Se até há pouco tempo o estudo das competências internacionais era relegada à categoria de parente pauvre do direito internacional privado, ou ainda como secondaire às questões dos conflitos das leis, o conflito de jurisdição conheceu recentemente certa désaffection por parte dos internacionalistas. $^{566}$

\footnotetext{
561 ALLARD, Julie; GARAPON, Antoine. Os juízes na mundialização: a nova revolução do direito. Lisboa: Instituto Piaget, 2005. p. 9.

562 JAYME, Erik, Identité culturelle et intégration: le droit international privé postmoderne, cit., p. 47-48.

563 FERNÁNDEZ ARROYO, Diego P. Propuestas para una evolución deseable del problema de la competencia judicial internacional. In: OYARZÁBAL, Mario J. A. (Coord.). Derecho procesal transnacional: homenaje al Profesor Doctor Gualberto Lucas Sosa. Argentina: Editorial Ábaco de Rodolfo Depalma, 2012. p. 140.

564 ABADE, Denise Neves. Direitos fundamentais na cooperação jurídica internacional. São Paulo: Saraiva, 2013; e CASELLA, Paulo Borba; SANCHEZ; Rodrigo Elian. Cooperação judiciária internacional. Rio de Janeiro: Renovar. 2002.

565 AUDIT, Bernard. Le droit international privé en quête d'universalité: cours général. Recueil des Cours de l'Académie de Droit International de La Haye, v. 305, p. 478, 2003.

${ }^{566}$ NIBOYET, Jean-Paulin. Traité de droit international privé français. Paris: Sirey, 1938. v. 6, p. 27.
} 
Segundo Diego Arroyo, hoje se discute autonomamente questões sobre a eficácia de decisões estrangeiras e de cooperação de autoridades, com sua própria forma de ser, "sus propias reglas y principios, y el derecho aplicable al fondo, si las afecta, sólo lo hace parcialmente". E todas essas razões fazem com que a determinação do direito aplicável não se situe mais no centro do direito internacional privado e que esse lugar seja ocupado agora pelos aspectos vinculados ao processo e à cooperação internacional - dentro dos quais a competência. Por conta disso, os temas dos conflitos de jurisdição tenham adquirido uma importância singular. ${ }^{567}$

Não obstante a multiplicação dos litígios internacionais ao longo das últimas décadas, a arbitragem internacional tomou um impulso gigantesco ${ }^{568}$, aumentando ainda mais as hipóteses de conflitos de competência e procedimentos paralelos, inclusive entre duas ou mais arbitragens internacionais. ${ }^{569}$

Muitas são as razões que levam ao forum shopping no cenário internacional. Razões econômicas, razões jurídicas, ou razões de abuso do processo. Talvez todas mais ou menos combinadas. E isso acontece, não obstante as tentativas de evitar sua ocorrência. ${ }^{570}$

A doutrina internacional tem apontado ao longo do tempo as desvantagens ou injustiças decorrentes do forum shopping, como uma atividade abusiva, maliciosa ou de má-prática. ${ }^{571}$

567 FERNÁNDEZ ARROYO, Diego P., Propuestas para una evolución deseable del problema de la competencia judicial internacional, cit., p. 142.

${ }^{568}$ MUIR WATT, Horatia. Économie de la justice et arbitrage international (réflexions sur la gouvernance privée dans la globalisation. Revue de l'Arbitrage, Paris, n. 3, p. 389, 2008.

${ }^{569}$ LEW, Julian D. M. Concluding remarks: parallel proceedings in international arbitration: challenges and realities. In: CREMADES, Bernardo M.; LEW, Julian D. M. (Eds.). Parallel state and arbitral procedures in international arbitration. Paris: ICC Publishing, 2005. p. 305-312. (Dossiers ICC Institute of World Business Law, 692).

${ }^{570}$ FORUM shopping reconsidered. Harvard Law Review, v. 103, n. 7, p. 1.678, May 1990; JUENGER, Friedrich K., What's wrong with forum shopping?, cit., p. 5; e GHEI, Nita; PARISI, Francesco. Adverse selection and moral hazard in forum shopping: conflicts law as spontaneous order. Cardozo Law Review, v. 25 , p. $1.368,2003$.

${ }^{571}$ John B. Corr aponta a "desonrosa" (disreputable) conotação do forum shopping; (Thoughts on the vitality of Erie. The American University Law Review, v. 41, p. 1.087, 1992) e Friedrich K. Juenger anota: "As a rule, counsel, judges, and academicians employ the term 'forum shopping' to reproach a litigant who, in their opinion, unfairly exploits jurisdictional or venue rules to affect the outcome of a lawsuit. But in spite of the phrase's pejorative connotation, forum shopping remains popular." (Forum shopping, domestic and international, cit., p. 553). 
Os litigantes, de um modo geral, têm à sua disposição meios e instrumentos para defesa de seus interesses, de acordo com a jurisdição em que estiverem, seja ela estatal ou arbitral. E a utilização desses meios e instrumentos se faz por intermédio de situações jurídicas subjetivas. Em princípio, se há competência internacional daquela corte, há espaço para livre atuação do demandante. Aplica-se a lição de Dinamarco: livre atuação é o conjunto de faculdades que as partes dispõem ao longo de todo o litígio, qualquer que seja a espécie deste ou o tipo de procedimento, relacionado à liberdade que elas têm para atuar "segundo suas próprias estratégias, sua vontade e sua conveniência". 572

Porém, a liberdade do litigante não é absoluta. O sujeito que a exerce não se exime das consequências desfavoráveis oriundas das escolhas que fizer ${ }^{573}$. No dizer de Michele Taruffo, o abuso dos remédios processuais - dentre os quais se incluem os litígios internacionais - está mais na escolha imprópria dos fins que o demandante pretende alcançar do que da escolha das modalidades com as quais os perseguirá. ${ }^{574}$

Calamandrei, em clássico estudo em que trata o processo como um jogo, tantas vezes citado neste trabalho, lança luzes sobre o desvio de finalidade como uma forma de se mostrar o abuso com que o litigante utiliza a ação. Dentro das várias situações de má-fé processual, muitas vezes a parte se serve dos processos para obter efeitos que não lhe são próprios. Segundo Calamandrei, tais hipóteses encontram-se em uma zona intermediária entre o dolo e a fraude e que, por guardar semelhança com a figura do abuso do direito, poderiam ser denominadas abuso do processo. ${ }^{575}$

O direito processual civil brasileiro, de certa forma, ignora o forum shopping abusivo. Ao afastar a litispendência internacional (art. 24 do NCPC), o sistema brasileiro reconhece a premência da coisa julgada (seja ela nacional ou estrangeira) como critério estabilizador do conflito. ${ }^{576}$

${ }^{572}$ DINAMARCO, Cândido Rangel, Instituições de direito processual civil, cit., v. 1, p. 226.

573 COUTURE, Eduardo José. Fundamentos do direito processual civil. Tradução de Rubens Gomes de Souza. São Paulo: Saraiva, 1946. p. 121; e ABDO, Helena Najjar, Abuso do processo, cit., p. 78.

${ }^{574}$ TARUFFO, Michele. Elementi per una definizione di “abuso del processo". In: STUDI in onore di Pietro Rescigno: responsabilità civile e tutela dei diritti. Milano: Giuffrè, 1998. v. 5, p. 1.124.

${ }^{575}$ CALAMANDREI, Piero, Il processo come giuoco, cit., p. 32.

576 ARAÚJO, Nadia; GAMA JUNIOR, Lauro; VARGAS, Daniela. Temas de direito internacional no projeto do novo Código de Processo Civil. Revista de Arbitragem e Mediação, São Paulo, Revista dos Tribunais, v. 8, n. 28, p. 148, jan./mar. 2011. 
Há a solução europeia, fundada no Regime de Bruxelas-Lugano: o princípio do actor sequitur forum rei, de antiga linhagem, em que a ação deve ser proposta, inicialmente e como regra geral, no domicílio do réu. Com uma política definida na velocidade com que a primeira ação é proposta, firma-se a jurisdição da corte do Estado membro em que a primeira demanda é proposta, até que ela decida sobre sua própria competência (Regulamento n. 1215/1012, art. 29). Esse sistema é criticado nos países do common law, por privilegiar automaticamente o réu que, num primeiro momento, é acusado de ter violado o direito do autor. Outra crítica comumente feita a esse sistema é que nem sempre o domicílio do réu é a melhor jurisdição para se colherem as provas, instruir o feito e analisar as evidências. ${ }^{577}$

Por seu turno, há os critérios subjetivos fixados pela jurisprudência nos países do common law e os remédios garantidores de sua própria competência, tal como as anti-suit injuctions, ou que afastam sua jurisdição, tal como a doutrina do forum non conveniens. Esses remédios, desenvolvidos com base na prudência e na repulsa ao forum shopping abusivo, acabaram sendo considerados como uma intromissão indevida em jurisdições alheias, cuja maior repulsa adveio do TJUE, no caso Turner $v$. Grovit. ${ }^{578}$

Mesmo o Protocolo de Las Leñas e seu esforço harmonizador não afastou o forum shopping abusivo no Mercosul. Não só por conta das imprecisões terminológicas já mencionadas anteriormente, mas tal qual o Regime de Bruxelas-Lugano, ao privilegiar o critério de fixação da competência pela velocidade com o que a primeira demanda é proposta, trás consigo o risco dos torpedos. ${ }^{579}$

Não obstante as tentativas frustradas de sistematização, a concorrência de foros como regra geral (a exclusividade como exceção) e as divergências fundamentais sobre os critérios mínimos de definição (que vão desde a indiferença da lei brasileira, à avocação manu militari das anti-suit injuctions do common law), parece forçoso reconhecer a necessidade de se estabelecerem critérios mínimos além dos quais será forçoso reconhecer a configuração do forum shopping como um abuso do direito, quer por deslealdade processual, quer por desvio de finalidade.

\footnotetext{
${ }^{577}$ VON MEHREN, Arthur Taylor, Must plaintiffs seek out defendants? The contemporary standing of actor sequitur forum rei, cit., p. 32.

${ }^{578}$ IVANOVA, Ekaterina. Choice of court clauses and lis pendens under Brussels I Regulation. Merkourios Utrecht Journal of International and European Law, v. 27, 2010, p. 14.

${ }^{579}$ CELLI JUNIOR, Umberto, Litispendência internacional no Brasil e no Mercosul, cit., p. 227.
} 


\section{REFERÊNCIAS}

ABADE, Denise Neves. Direitos fundamentais na cooperação jurídica internacional: extradição, assistência jurídica, execução de sentença estrangeira e transferência de presos. São Paulo: Saraiva, 2013.

ABDO, Helena Najjar. Abuso do processo. São Paulo: Revista dos Tribunais, 2007.

ACCIOLY, Hildebrando; SILVA, Geraldo Eulálio do Nascimento e; CASELLA, Paulo Borba. 19. ed. Manual de direito internacional público. São Paulo: Saraiva, 2011.

ADLER, Barry E. A re-examination of near-bankruptcy investiment incentives. University of Chigago Law Review, v. 62, No. 2, p. 575-606, Spring, 1995.

AGUIAR JÚNIOR, Ruy Rosado de. Protocolo de Buenos Aires sobre jurisdição internacional. Revista do Instituto dos Advogados de São Paulo, Nova série, v. 3, n. 6, p. 189-203, jul./dez. 2000.

ALGERO, Mary Garvery. In defense of forum shopping: a realistic look at selecting a venue. Nebraska Law Review, Lincoln, College of Law, University of Nebraska, v. 78, n. 1, p. 79-112, 1999.

ALLARD, Julie; GARAPON, Antoine. Os juízes na mundialização: a nova revolução do direito. Tradução de Rogério Alves. Lisboa: Instituto Piaget, 2006.

AMBROSE, Clare. Can anti-suit injunctions survive European community law? International and Comparative Law Quarterly, v. 52, No. 2, p. 401-424, 2003.

ARAGÃO, Egas Dirceu Moniz de. Comentários ao Código de Processo Civil. Rio de Janeiro: Forense, 1992. v. 1.

ARAÚJO, Francisco Fernandes de. O abuso do direito processual e o princípio da proporcionalidade na execução civil. Rio de Janeiro: Forense, 2004.

ARAÚJO, Nádia de. Direito internacional privado: teoria e prática brasileira. 4. ed. atual. e ampl. Rio de Janeiro: Renovar, 2008.

. A nova lei de arbitragem brasileira e os "princípios uniformes dos contratos comerciais internacionais", elaborados pela UNIDROIT. In: CASELLA, Paulo Borba (Coord.). Arbitragem: lei brasileira e praxe internacional. 2. ed. ed. rev. e aum. São Paulo: LTr, 1999. p. 133-162.

. O STJ e a homologação de sentenças arbitrais estrangeiras: dez anos de atuação. In: TIBURCIO, Carmen; MENEZES, Wagner; VASCONCELOS, Raphael (Orgs.). Panorama do direito internacional privado atual e outros temas contemporâneos: festschrift ao professor Jacob Dolinger. Belo Horizonte: Arraes, 2015. p. 155-180. 
ARAÚJO, Nadia; GAMA JUNIOR, Lauro; VARGAS, Daniela. Temas de direito internacional no projeto do novo Código de Processo Civil. Revista de Arbitragem e Mediação, São Paulo, Revista dos Tribunais, v. 8, n. 28, p. 147-158, jan./mar. 2011.

ARMELIN, Donaldo. Competência internacional. Revista de Processo, São Paulo, Revista dos Tribunais, v. 1, n. 2, p. 131-158, abr./jun. 1976.

ARRUDA ALVIM, José Manuel de. Competência internacional. Revista de Processo, São Paulo, Revista dos Tribunais, v. 2, n. 7/8, p. 24, jul./dez. 1977.

Ensaio sobre a litispendência no direito processual civil. São Paulo: Revista dos Tribunais, 1970. v. 2.

AUDIT, Bernard. Le droit international privé en quête duniversalité. Recueil des Cours de l'Académie de Droit International de La Haye, v. 305, p. 9-488, 2003.

ÁVILA, Humberto Bergmann. A distinção entre princípios e regras e a redefinição do dever de proporcionalidade. Revista de Direito Administrativo, Rio de Janeiro, n. 215, p. 152, jan./mar. 1999.

Teoria dos princípios: da definição à aplicação dos princípios jurídicos. 3. ed. aum. São Paulo: Malheiros, 2004.

BAPTISTA, Luiz Olavo. Aplicação do direito estrangeiro pelo juiz brasileiro. Revista de Informação Legislativa, v. 36, n. 142, p. 267-277, abr./jun. 1999.

BARBI, Celso Agrícola. Comentários ao Código de Processo Civil: Lei n. 5.869, de 11 de janeiro de 1973: arts. $1^{\circ}$ a 153. 14. ed. rev. e atual. por Bernardo Pimentel Souza. Rio de Janeiro: Forense, 2010. v. 1.

BARRETT, Edward L. The doctrine of forum non conveniens. California Law Review, v. 35, No. 3, p. 380-422, 1947.

BASSETT, Debra Lyn. The forum game. North Carolina Law Review, Chapel Hill, NC, v. 84, p. 373, 2006. Disponível em:

<http://papers.ssrn.com/sol3/papers.cfm?abstract_id=832026>. Acesso em 30 abr. 2014.

BASSO, Maristela. Curso de direito internacional privado. São Paulo: Atlas, 2009.

Direito internacional da propriedade intelectual. Porto Alegre: Livraria do Advogado, 2000.

BASSO, Maristela; CARVALHO, Patrícia Luciane de (Orgs.). Lições de direito internacional: estudos e pareceres de Luiz Olavo Baptista. Curitiba: Juruá, 2008.

BATTIFOL, Henri. Traité élémentaire de droit international privé. 3e. éd. Paris: Librairie Générale de Droit et de Jurisprudence, 1959. 
BEDAQUE, José Roberto dos Santos. Competência: aspectos teóricos e práticos. Revista do Advogado, São Paulo, AASP, v. 25, n. 84, p. 90-118, dez. 2005.

Direito e processo: influência do direito material sobre o processo. São Paulo: Malheiros, 1995.

BELL, Andrew S. Forum shopping and venue in transnational litigation. Oxford: Oxford University Press, 2003. Disponível em:

<http://scholarship.kentlaw.iit.edu/cklawreview/vol78/iss1/6>. Acesso em: 30 abr. 2014.

BEHR, Volker. Punitive damages in America and German Law: tendencies towards approximation of apparently irreconcilable concepts. Chicago-Kent Law Review, Chicago, v. 78, n. 1, p. 105-161, Jan. 2003. Disponível em:

<http://scholarship.kentlaw.iit.edu/cklawreview/vol78/iss1/6>. Acesso em: 30 abr. 2014.

BERMANN, George A. The use of anti-suits injunctions in international litigation.

Columbia Journal of Transnational Law, v. 28, p. 589-594, 1990.

BEVILAQUA, Clovis. Código Civil dos Estados Unidos do Brasil commentado. 4. ed. Rio de Janeiro: Francisco Alves, 1934.

BICKEL, Alexander M. The doctrine of foreign non conveniens as applied in the Federal Courts in matters of admiralty: an object lesson in uncontrolled discretion. Cornell Law Quartely, v. 35, p. 12-47, 1949-1950.

BIES, John. Conditioning forum non conveniens. The University of Chicago Law Review, v. 67 , No. 2, p. 489-519, Spring 2000.

BLAIR, Paxton. The doctrine of forum non conveniens in anglo-american law. Columbia Law Review, v. 29, No. 1, p. 21, 1929.

BOBBIO, Norberto. A era dos direitos. Rio de Janeiro: Campus; Elsevier, 2004.

BODONI, Stéphanie. Where to find value in Europe. Managing Intellectual Property, n. 30, setembro de 2004.

BOGGIANO, Antonio. Curso de derecho internacional privado, derecho de las relaciones privadas internacionales. 3. ed. Buenos Aires: Abeledo-Perrot, 2001.

BONAVIDES, Paulo. Curso de direito constitucional. 18. ed. atual. São Paulo: Malheiros, 2006.

BORCHERS, Patrick Joseph. The internationalization of contractual conflicts law. Vanderbilt Journal of Transnational Law, v. 28, p. 423, May 1995.

The real risk of forum shopping: a dissent from Shady Grove. Creighton Law

Review, v. 44, p. 29-41, 2010. 
BOUCARON-NARDETTO, Magali. Le principe compétence-compétence en droit de l'arbitrage. Aix-en-Provence: Presses Universitaires d'Aix-Marseille, 2013.

BRAND, Ronald; JABLONSKI, Scotti R. Forum non conveniens: history, global practice, and future under the Hague Convention on Choice of Court Agreements. Oxford; New York: Oxford University Press, 2007.

BRAUCHER, Robert. The inconvenient federal forum. Harvard Law Review, v. 60, p. 908, 1947.

BROWER, Amy J. (Ed.). Libel tourism and foreign libel lawsuits. Hauppauge, NY: Nova Science, 2011.

BROWN, George D. The ideologies of forum shopping: why doesn't a conservative court protect defendants? North Carolina Law Review, v. 71, No. 1, p. 649-720, 1993.

CAGGIANO, Mônica Herman Salem. Os direitos fundamentais e sua universalização. Revista Brasileira de Direito Constitucional, n. 4, p. 760, jul./dez. 2004.

CALAMANDREI, Piero. Il processo come giuoco. Rivista de Diritto Processuale, Padova, Cedam, v. 5, n. 1, p. 23-51, 1950.

CAMARGO, Solano de. Forum necessitatis: uma proposta de flexibilização dos critérios de competência internacional da justiça brasileira. In: MENEZES, Wagner et al. (Orgs.). Direito internacional em expansão. Belo Horizonte: Arraes, 2014. v. 4, p. 478-486.

CAMERON, Christopher D.; JOHNSON, Kevin R. Death of a salesman? Forum shopping and outcome determination under international shoe. UC Davis Law Review, University of California, v. 28, No. 3, p. 769-862, 1994-1995. Disponível em:

<http://lawreview.law.ucdavis.edu/issues/28/3/articles/DavisVol28No3_Cameron.pdf>. Acesso em: 15 maio 2015.

CAMPUZANO DÍAZ, Beatriz. Las normas de competencia judicial internacional del reglamento 1215/2012 y los demandados domiciliados fuera de la UE: análisis de la reforma. Revista Electrónica de Estudios Internacionales, v. 28, p. 1-35, 2014. Disponível em: <http://www.reei.org/index.php/revista/num28/articulos/normas-competencia-judicialinternacional-reglamento-12152012-demandados-domiciliados-fuera-ue-analisis-reforma> . Acesso em: 15 maio 2015.

CANOTILHO, José Joaquim Gomes. Direito constitucional e teoria da Constituição. Coimbra: Almedina, 2003.

CAPPELLETTI, Mauro; GARTH, Bryant. Acesso à justiça. Porto Alegre: Sergio Antonio Fabris, 1988. p. 15.

CARDOSO, Oscar Valente. Litispendência e coisa julgada nos processos dos tribunais internacionais. Revista Dialética de Direito Processual, São Paulo, n. 118, p. 56-70, jan. 2013. 
CARDOSO, Vladimir Mucury. O abuso do direito na perspectiva civil-constitucional. In: MORAES, Maria Celina Bodin de (Coord.). Princípios do direito civil contemporâneo. Rio de Janeiro: Renovar, 2006. p. 61-109.

CARMONA, Carlos Alberto. Arbitragem e processo: um comentário à Lei n. 9.307/96. São Paulo: Atlas, 2004.

CARNEIRO, Athos Gusmão. Jurisdição e competência: exposição didática, área do direito processual civil. 13. ed. São Paulo: Saraiva, 2004.

. O juiz conservador da nação britânica. Revista de Informação Legislativa, Brasília, v. 14, n. 56, p. 239-246, out./dez. 1977.

CARNELUTTI, Francesco. Diritto e processo. Nápoli: Morano, 1958.

. Sistema de diritto processuale civile. Padova: CEDAM, 1936. v. 1.

CASELLA, Paulo Borba. Autonomia da vontade, arbitragem comercial internacional e direito brasileiro. In: TIBURCIO, Carmen; BARROSO, Luis Roberto. $O$ direito internacional contemporâneo: estudos em homenagem ao professor Jacob Dolinger. Rio de Janeiro: Renovar, 2006. p. 737-750.

CASELLA, Paulo Borba; SANCHEZ, Rodrigo Elian. Cooperação judiciária internacional. Rio de Janeiro: Renovar, 2002.

CASTRO, Amilcar de. Direito internacional privado. Rio de Janeiro: Forense, 1987. v. 1.

CELLI JUNIOR, Umberto. Litispendência internacional no Brasil e no Mercosul. Revista Brasileira de Direito Processual, v. 19, n. 76, p. 219-234, out./dez. 2011.

EUROPEAN COMMISSION FOR THE EFFICIENCY OF JUSTICE (CEPEJ). Report on "European judicial systems - Edition 2014 (2012 data): efficiency and quality of justice". Disponível em:

<http://www.coe.int/t/dghl/cooperation/cepej/evaluation/2014/Rapport_2014_en.pdf>. Acesso em: 15 maio 2015.

CHALAS, Christelle. L'exercice discrétionnaire de la compétence juridictionnelle en droit international privé. Aix-en-Provence: Presses Universitaire d'Aix-Marseille, Faculté de Droit et de Science Politique, 2000. v. 1.

CHAO, Cedric; NEUHOFF, Christine. Enforcement and recognition of foreign judgments in United States courts: a practical perspective. Pepperdine Law Review, v. 29, p. 147, 2001.

CHESHIRE, Geoffrey C.; NORTH, Peter M. Private international law. London: Butterworth, 1987.

CHESTERMAN, Michael. Contempt: in the common law, but not the civil law. International and Comparative Law Quarterly, v. 46, p. 524, 1997. 
CHIOVENDA, Giuseppe. Instituições de direito processual civil. Tradução da 2. ed. italiana por J. Guimarães Menegale; acompanhada de notas pelo prof. Enrico Tullio Liebman. São Paulo: Saraiva, 1943. v. 1.

CHUANG, Chester S. Offensive venue: the curious use of declaratory judgment to forum shop in patent litigation. The George Washington Law Review, v. 80, No. 4, p. 1.0651.114, June 2012. Disponível em:

<http://groups.law.gwu.edu/LR/ArticlePDF/80_4_Chuang.pdf>. Acesso em: 30 abr. 2014.

CINTRA, Antônio Carlos de Araújo; GRINOVER, Ada Pellegrini; DINAMARCO, Candido Rangel. Teoria geral do processo. 30. ed. São Paulo: Malheiros, 2014.

CLERMONT, Kevin M.; EISENBERG, Theodore. Exorcising the evil of forum shopping. Cornell Law Review, v. 80, No. 6, p. 1.507-1.535, Sept. 1995. Disponível em:

<http://scholarship.law.cornell.edu/facpub/245>. Acesso em: 30 abr. 2014.

CLERMONT, Kevin M.; PALMER, John R. B. Exorbitant jurisdiction. Maine Law Review, v. 58, No. 2, p. 474-505, 2006.

CODDINGTON, Clinton H.; HICKS, Randolph S. The arena: defendant's choice of forum. Journal of Air Law and Commerce, v. 46, p. 941, 1981.

COLLINS, Lawrence. Contractual obligations - the EEC preliminary draft convention on private international law. International and Comparative Law Quarterly, v. 25, No. 1, p. 35, Jan. 1976.

COOTER, Robert; ULEN, Thomas. Law and economics. Boston: Pearson Addison Wesley, 2007.

CORDEIRO, António Menezes. Da boa-fé no direito civil. Coimbra: Almedina, 1997.

Do abuso do direito: estado das questões e perspectivas. Revista da Ordem dos Advogados, Lisboa, ano 65, v. 2, p. 330, set. 2005.

CORR, John B. Corr Thoughts on the vitality of Erie. The American University Law Review, v. 41, p. 1.087, 1992.

CORREIA, António de Arruda Ferrer. Lições de direito internacional privado. Lisboa: Almedina, 2010. v. 1.

Reflexões sobre competência internacional indireta. In: Estudos vários de direito. Coimbra: Universidade de Coimbra, 1982.

COSTA, José Augusto Fontoura. A vontade e a forma: a percepção da arbitragem no caso do contrato de seguro do Projeto Jirau. Revista de Arbitragem e Mediação, São Paulo, Revista dos Tribunais, v. 10, n. 38, p. 35-60, jul./set. 2013.

COUTURE, Eduardo José. Fundamentos do direito processual civil. Tradução de Rubens Gomes de Souza. São Paulo: Saraiva, 1946. 
CRUMP, David. The case for restricting diversity jurisdiction: the undeveloped arguments, from the race to the bottom to the substitution effect. Maine Law Review, v. 62, p. 9, 2010.

DÁVALOS FERNÁNDEZ, Rodolfo. El conflicto de jurisdicciones o de competencia judicial internacional. Revista Cubana de Derecho, Havana, Unión Nacional de Juristas de Cuba, v. 30, n. 0, p. 62-87, dic. 2007. Disponivel em: <http://vlex.com/vid/conflictojurisdicciones-competencia-50036875>. Acesso em: 10 maio 2014.

DE LY, Filip. Forum shopping and the determination of the place of arbitration. In: FERRARI, Franco (Ed.). Forum shopping in the international commercial arbitration context. Munich: Sellier European Law Publishers (SELP), 2013. p. 53-68.

DE VISSCHER, Charles. Le déni de justice en droit international. Recueil des Cours de l'Académie de Droit International de La Haye, v. 52, p. 365, 1935.

DEKKER, Bart. Exorbitant jurisdiction: law as an off-track 4by4. Comparative Civil Procedural Law Paper, v. 2, p. 2, 2013.

DIDIER JUNIOR, Fredie; BRAGA, Paula Sarno; OLIVEIRA, Rafael. Curso de direito processual civil: direito probatório, decisão judicial, cumprimento e liquidação da sentença e coisa julgada. 3. ed. rev., ampl. e atual. Salvador: JusPodivm, 2008. v. 2.

DIDIER JUNIOR, Fredie; ZANETI JÚNIOR, Hermes. Curso de direito processual civil: processo coletivo. 6. ed. rev., ampl. e atual. Salvador: JusPodivm, 2011. v. 4.

DINAMARCO, Cândido Rangel. Instituições de direito processual civil. São Paulo: Malheiros, 2001. v. 1.

A instrumentalidade do processo. 15. ed. São Paulo: Malheiros, 2013.

Litisconsórcio. 5. ed. São Paulo: Malheiros, 1997.

. Mandado de segurança: execução provisória. Revista dos Tribunais, São Paulo, v. 70, n. 543, p. 25-38, jan. 1981.

DINIZ, Maria Helena. Lei de Introdução ao Código Civil. São Paulo: Saraiva, 2010.

DIXIT, Avinash K.; SKEATH, Susan. Games of strategy. 2nd ed. New York: W. W. Norton, 2004.

DOLINGER, Jacob. Direito internacional privado: parte geral. Rio de Janeiro: Freitas Bastos, 1986.

. A evolução da ordem pública no direito internacional privado. Rio de Janeiro: Renovar, 1979.

DUVAL-MAJOR, Jacqueline. One-way ticket home: the federal doctrine of forum non conveniens and the international plaintiff. Cornell Law Review, v. 77, p. 670, 1991. 
EISENGRAEBER, J. Lis alibi pendens under the Brussels I Regulation: how to minimise 'torpedo litigation' and other unwanted effects of the 'first-come, first-served' rule. 2004. Dissertation (Master of Law in International Business Law) - Centre for European Legal Studies, University of Exeter, Exeter, UK, 2004. (Papers in European Law, No. 16). Disponível em:

<http://law.exeter.ac.uk/cels/documents/papepr_llm_03_04_dissertation_Eisengraeber_001 .pdf $>$. Acesso em: 12 maio 2014).

ELVIRA BENAYAS, María Jesús. ¿Existe alguna posibilitad, por pequeña que sea, de salvar lo nuestro? Las anti-suit injunction y el convenio de Bruselas. A propósito de la STJCE de 27 de abril de 2004 (C-159/02). Revista Electrónica de Estudios Internacionales, v. 9, 2005. Disponível em: <http://dialnet.unirioja.es/ejemplar/108387>. Acesso em: 15 maio 2015.

ESPÍNOLA, Eduardo; ESPÍNOLA FILHO, Eduardo. Do direito internacional privado brasileiro. In: Tratado de direito civil brasileiro. Rio de Janeiro: Freitas Bastos, 1942. v. 8 , t. 1 .

;___ Lei de Introdução ao Código Civil brasileiro comentado. Rio de Janeiro:

Freitas Bastos, 1943. v. 1-2.

FARIA, José Eduardo. Direito e globalização econômica: implicações e perspectivas. São Paulo: Malheiros, 2010.

FELDMAN, Michelle. Putting the brakes on libel tourism: examining the effects tests as a basis for personal jurisdiction under NewYork's Libel Terrorism Protection Act. Cardozo Law Review, v. 31, p. 6, 2010.

FERNÁNDEZ ARROYO, Diego P. Aspectos esenciales de la competencia judicial internacional en vistas de su reglamentación interamericana. In: PICAND ALBÓNICO, Eduardo; LLANOS MANSILLA, Hugo (Coords.). Estudios de derecho internacional: libro homenaje al profesor Santiago Benadava. Santiago de Chile: Livrotecnia, 2008. v. 2, p. 293-326.

Compétence exclusive et compétence exorbitante dans les relations privées internationales. Recueil des Cours de l'Académie de Droit International de La Haye, v. 323, p. 9-259, 2006.

El derecho internacional privado en el inicio del siglo XXI. Caderno da PósGraduação em Direito - PPGDir./UFRGS, v. 1, n. 2, p. 209-226, set. 2003.

Propuestas para una evolución deseable del problema de la competencia judicial internacional. In: OYARZÁBAL, Mario J. A. (Coord.). Derecho procesal transnacional: homenaje al Profesor Doctor Gualberto Lucas Sosa. Argentina: Editorial Ábaco de Rodolfo Depalma, 2012. p. 139-174.

FERRARI, Franco (Ed.). Forum shopping in the international commercial arbitration context. Munich: Sellier European Law Publishers (SELP), 2013. 
FERRAZ JÚNIOR, Tércio Sampaio. Introdução ao estudo do direito: técnica, decisão, dominação. 3. ed. São Paulo: Atlas, 2001.

FORUM shopping reconsidered. Harvard Law Review, v. 103, n. 7, p. 1677-1696, May 1990.

FOSTER, Roger S. Place of trial-interstate application of intrastate methods of adjustment. Harvard Law Review, v. 44, p. 41, 1986.

FRAGISTAS, Charalambos N. La compétence internacionale en droit privé. Recueil des Cours de l'Académie de Droit International de La Haye, v. 104, n. 3, p. 167, 1961.

FRANZOSI, Mario. Worldwide patent litigation and the italian torpedo. Disponível em: <http://www.franzosi.com/articolo/1997/worldwide-patent-litigation-and-the-italiantorpedo>. Acesso em: 23 maio 2015

FRY, Taryn M. Injuction junction, what's your function? Resolving the split over anti-suit injuction deference in favor of international comity. Catholic University Law Review, v. 58, p. 1.073, 2008-2009.

GAILLARD, Emmanuel (Ed.). Anti-suit injunctions in international arbitrations. IAI Seminar, Paris, November 21, 2003. Huntington, NY: Juris Publishing; Bern: Staempfli, 2005.

GERNY, Marissa. The SPEECH act defends the First Amendment: a visible and targeted response to libel tourism. Seton Hall Legislative Journal, v. 36, No. 2, p. 409-443, 2012. Disponível em:

$<$ http://scholarship.shu.edu/cgi/viewcontent.cgi?article=1034\&context=shlj $>$. Acesso em: 15 maio 2015.

GHEI, Nita; PARISI, Francesco. Adverse selection and moral hazard in forum shopping: conflicts law as spontaneous order. Cardozo Law Review, v. 25, p. 1.368, 2003.

GILSON, Ronald J.; MNOOKIN, Robert H. Disputing through agents: cooperation and conflict between lawyers in litigation. Columbia Law Review, v. 94, p. 509, 1994.

GINSBURG, Ruth Bader; BRUZELIUS, Anders. Civil procedure in Sweden. Haia: Martinus Nijhoff, 1965.

GLENN, H. Patrick. The ALI/UNIDROIT principles of transnational civil procedure as global standards for adjudication? Uniform Law Review = Revue de Droit Uniforme, Rome, v. 9, n. 4, p. 829-845, 2004.

GOLDSCHMIDT, James. Derecho procesal civil. Barcelona: Labor, 1936.

GOLDSCHMIDT, Werner. Sistema e filosofía del derecho internacional privado. 2. ed. Buenos Aires: Ediciones Jurídicas Europa-América, 1952. v. 3. 
GÓMEZ, Manuel A. The global chase: seeking the recognition and enforcement of the Lago Agrio judgment outside of Ecuador. Stanford Journal of Complex Litigation, v. 1, No. 2, p. 429-466, Spring 2013.

GOMES, Orlando. Contratos. 24. ed. Atualização e notas de Humberto Theodoro Júnior. Rio de Janeiro: Forense, 2001.

GOTTESMAN, Michael, H. Draining the dismal swamp: the case for federal choice of law statutes. Georgetown Law Journal, v. 80, p. 13, 1991.

GRECO, Leonardo. A competência internacional da justiça brasileira. Revista da Faculdade de Direito de Campos, Campos dos Goytacazes, RJ, v. 6, n. 7, p. 169-193, dez. 2005.

GREENBERG, Mark D. The appropriate source of law for forum non conveniens decisions in international cases: a proposal for the development of federal common law. Berkeley Journal of International Law, v. 4, p. 159, 1986.

GRINOVER, Ada Pellegrini. Os princípios constitucionais e o Código de Processo Civil. São Paulo: Bushatsky, 1975.

GROSS, Leo. The Peace of Westphalia, 1648-1948. American Journal of International Law, v. 42, p. 20, 1948.

GROSSI, Simona. The U.S. Supreme Court's modern common law approach. Cambridge: Cambridge University Press, 2015.

GUERRA, Marcel Vitor de Magalhães; MOSCHEN, Valesca Raizer Borges. Influências do common law no Brasil. Questão relacionada ao forum shopping: afinal, é possível a um juiz nacional derrogar sua competência internacional com base na doutrina estrangeira do forum non conveniens?. In: ENCONTRO NACIONAL DO CONPEDI: Direitos fundamentais e transdisciplinariedade, 19., 2010, Fortaleza, CE. Anais... Florianópolis: Fundação Boiteux, 2010. p. 3.707-3.716. Disponível em: <http://www.conpedi.org.br/manaus/arquivos/anais/fortaleza/3365.pdf>. Acesso em: 20 maio 2015.

.; _ Processo civil transnacional: a caminho de uma sistematização dos princípios de competência internacional: reflexos de um novo paradigma axiológico face à crise metodológica positivista. In: ENCONTRO NACIONAL DO CONPEDI: as dimensões da personalidade na contemporaneidade, 18., 2009, Maringá, PR. Anais... Florianópolis: Fundação Boiteux, 2009. p. 4.797-4.816. Disponível em: <http://www.conpedi.org.br/anais/36/09_1442.pdf>. Acesso em: 01 maio 2014.

GUIMARÃES, Mário. O juiz e a função jurisdicional. Rio de Janeiro: Forense, 1958.

GUTHRIE, Neil. "A good place to shop": choice of forum and the conflict of laws. Otawa Law Review, v. 27, p. 203-231, 1995. 
HANDEYSIDE, Hugh. The lotus principle in ICJ jurisprudence: was the ship ever afloat? Michigan Journal of International Law, Ann Arbor, Mich., University of Michigan Law School, v. 29, No. 1, p. 71-94, Fall 2007.

HARNON, Eliahu. Civil and criminal contempts of court. The Modern Law Review, v. 25, p. $187,1962$.

HARTLEY, Trevor C. Anti-suit injunctions and the Brussels Jurisdiction and Judgment Convention. International and Comparative Law Quarterly, v. 44, p. 164, 2000.

Comity and the use of anti-suit injunctions in international litigation. The American Journal of Comparative Law, v. 35, n. 3, p. 490, 1987.

How to abuse the law and (maybe) come out on top: bad-faith proceedings under the Brussels jurisdiction and judgments conventions. King's College Law Journal, v. 13, No. 2, p. 139-148, 2002.

HIXSON, Kathleen. Extraterritorial jurisdiction under the Third Restatement of Foreign Relations Law of the United States. Fordham International Law Journal, v. 12, p. 127, 1988.

HÖFFE, Otfried. A democracia no mundo de hoje. Tradução de Tito Lívio Cruz Romão. São Paulo: Martins Fontes, 2005.

HÖRNLE, Julia. Cross-border internet dispute resolution. Cambridge, UK; New York: Cambridge University Press, 2009.

HOUAISS, Antônio. Dicionário Houaiss da língua portuguesa. Rio de Janeiro: Objetiva, 2009.

HUCK, Hermes Marcelo. Sentença estrangeira e lex mercatoria: horizontes e fronteiras do comércio internacional. São Paulo: Saraiva, 1994.

INFORMATION concerning the Hague Conventions on Private International Law. Netherlands International Law Review, Dordrecht, Netherlands, Martinus Nijhoff Publishers, v. 36, No. 2, p. 185-210, Aug. 1989.

INTERNATIONAL LAW ASSOCIATION. Resolution No. 1/2000. International Civil and Commercial Litigation. The 69th Conference of the International Law Association, held in London, United Kingdom, 25th-29th July 2000. Disponível em: <http://www.ilahq.org/en/committees/index.cfm/cid/18>. Acesso em: 16 maio 2015.

INSTITUT DE DROIT INTERNATIONAL. 2ème Commission. Session de Bruges. Resolution du 02.09.2003. Le recours à la doctrine du forum non conveniens et aux "antisuit injunctions": principes directeurs. Disponível em: <http://www.idiiil.org/idiF/resolutionsF/2003_bru_01_fr.pdf>. Acesso em:16 maio 2015.

IVANOVA, Ekaterina. Choice of court clauses and lis pendens under Brussels I Regulation. Merkourios - Utrecht Journal of International and European Law, v. 27, 2010, p. 14. 
JANDOLI, Vincenzo. The "italian torpedo". International Review of Intellectual Property and Competition Law IIC, Munich, v. 31, p. 783, 2000.

JATAHY, Vera Maria Barrera. Do conflito de jurisdições: a competência internacional da justiça brasileira. Rio de Janeiro: Forense, 2003.

JAYME, Erik. O direito internacional privado do novo milênio: a proteção da pessoa humana face à globalização. Cadernos do Programa de Pós-Graduação em Direito PPGDir./UFRGS, v. 1, n. 1, p. 133-146, mar. 2003. Disponível em: <http://seer.ufrgs.br/index.php/ppgdir/article/view/43490/27368>. Acesso em: 16 maio 2015.

. Formação progressiva do direito internacional privado por parte dos juízes: a experiência americana e alemã até 1986. Cadernos do Programa de Pós-Graduação em Direito-PPGDir./UFRGS, v. 1, n. 1, p. 69-91, mar. 2003. Disponível em: <http://seer.ufrgs.br/index.php/ppgdir/article/view/43485/27364>. Acesso em: 16 maio 2015.

Identité culturelle et intégration: le droit international privé post moderne. Recueil des Cours de l'Académie de Droit International de La Haye, v. 251, p. 44, 1995.

JELLINEK, Georg. Teoria general del Estado. Traducción y prólogo de la segunda edición alemana por Fernando de los Ríos Urruti. México: Fondo de Cultura Económica, 2000 .

JOSSERAND, Louis. De l'esprit des droits et leur relativité. Théorie dite de l'abus des droits. Paris: Dalloz, 1927. p. 312.

JUENGER, Friedrich K. Forum shopping, domestic and international. Tulane Law Review, v. 63 , p. $553,1988-1989$.

. Some comments on European procedural harmonization. The American Journal of Comparative Law, v. 45, p. 933, 1997. Mar. 1994.

What's wrong with forum shopping? Sydney Law Review, v. 16, No. 1, p. 5-13,

KERRY, John; BROWN, Hank. The BCCI affair: a report to the Committee on Foreign Relations United States Senate, Senate Print No. 102-140, December 1992, 102d Congress, 2nd Session. Disponível em: <https://info.publicintelligence.net/The-BCCI-Affair.pdf>. Acesso em: 15 maio 2015.

KESSEDJIAN, Catherine. International jurisdiction and foreign judgments and commercial matters. Preliminary Document n. 7 of April 1997 for the attention of the Special Commission of June 1997 on the question of jurisdiction, and recognition and enforcement of foreign judgments in civil and commercial matters. Disponível em: <http://www.hcch.net/upload/wop/jdgm_pd7.pdf>. Acesso em: 25 maio 2014.

KOEHNEN, Markus. Reasonable expectations and a principled approach to forum shopping. Advocate's Quarterly, v. 19, p. 311, 1997. 
KOHL, Uta. Jurisdiction and the internet: regulatory competence over online activity. Cambridge; New York: Cambridge University Press, 2007.

KOPPEL, Glenn S. Toward a new federalism in state civil justice: developing a uniform code of state civil procedure through a collaborative rule-making process. Vanderbilt Law Review, v. 58, p. 1.167, 2005.

KOZIOL, Helmut. Punitive damages: a european perspective. Lousiana Law Review, v. 68, p. 741, 2008.

KREINDLER, Richard H. Competence-competence in the face of illegality in contracts and arbitration agreements. Recueil des Cours de l'Académie de Droit International de La Haye, v. 361, 2013.

LAFER, Celso. A reconstrução dos direitos humanos: um diálogo com o pensamento de Hannah Arendt. São Paulo: Companhia das Letras, 1991.

LEAL, Stela Tannure. Lealdade processual, dever de veracidade e estado social. Revista Ética e Filosofia Política, Juiz de Fora, MG, UFJF, v. 2, n. 15, p. 86-102, dez. 2012.

LEW, Julian D. M. Concluding remarks: parallel proceedings in international arbitration: challenges and realities. In: CREMADES, Bernardo M.; LEW, Julian D. M. (Eds.). Parallel state and arbitral procedures in international arbitration. Paris: ICC Publishing, 2005. p. 305-312. (Dossiers ICC Institute of World Business Law, 692).

LIEBMAN, Enrico Tullio. L'azione nella teoria del processo civile. In: SCRITTI giuridici in onore di Francesco Carnelutti. Padova: CEDAM, 1950. v. 2, p. 47-71.

Os limites da jurisdição brasileira. In: Estudos sobre o processo civil brasileiro. São Paulo: Saraiva, 1947. p. 18-26.. Manual de direito processual civil. Palmas: Intelectus, 2003. v. 1.

LIMA, Patrícia Carla de Deus. O abuso do direito de defesa no processo civil: reflexões sobre o tema no direito e na doutrina italiana. Revista de Processo, São Paulo, Revista dos Tribunais, v. 30, n. 122, p. 93-129, abr. 2005.

LOPES, Miguel Maria Serpa. Comentários à Lei de introdução ao Código Civil. 2. ed. rev. e aum. Rio de Janeiro: Freitas Bastos, 1959. v. 3.

LOPEZ, Teresa Ancona. Exercício do direito e suas limitações: abuso do direito. Revista dos Tribunais, São Paulo, v. 98, n. 885, p. 49-68, jul. 2009.

LÓPEZ-TARRUELLA MARTÍNEZ, Aurelio. Litigios transfronterizos sobre derechos de propiedad industrial e intelectual. Madrid: Dykinson, 2008.

LOPUCKI, Lynn M.; WEIRAUCH, Walter O. A theory of legal strategy. Duke Law Journal, v. 49, p. 1.429, 2000. 
LORENZEN, Ernest G. Huber's de conflict legum. Illinois Law Review, v. 13, p. 375-403, 1919.

LOULA, Maria Rosa Guimarães. A extraterritorialidade das sentenças no Protocolo de Las Leñas sobre cooperação e assistência jurisdicional em matéria civil, comercial, trabalhista e administrativa. In: TIBURCIO, Carmen; BARROSO, Luís Roberto (Orgs.). O direito internacional contemporâneo: estudos em homenagem ao professor Jacob Dolinger. Rio de Janeiro: Renovar, 2006. p. 651-678.

LOWENFELD, Andreas. Forum shopping, antisuit injunctions, negative declarations, and related tools of international litigation. Editorial comment. American Journal of International Law, v. 91, No. 2, p. 314-324, 1997.

LUÍS, Daniel Tavela; COSTA, José Augusto Fontoura. A internacionalização pelo novo CPC. Valor Econômico, de 12 jun. 2015, p. E2. Disponível em: <http://www.valor.com.br/legislacao/4090938/internacionalizacao-pelo-novo-cpc>. Acesso em: 15 jun. 2014.

MACCORMICK, Neil. Universalisation and induction in law. In: FARALLI, Carla; PATTARE, Enrico (Coords.). Reason in law. Milano: Giuffrè, 1987. v. 1.

MAGALHÃES, José Carlos de. Fatores de limitação da jurisdição do Estado. Revista dos Tribunais, São Paulo, v. 88, n. 767, p. 46-58, set. 1999.

O protocolo de Las Leñas e a eficácia extraterritorial das sentenças e laudos arbitrais proferidos nos países do Mercosul. Revista de Informação Legislativa, Brasília, DF, v. 36, n. 144, p. 281-291, out./dez. 1999.

MALOY, Richard. Forum shopping? What's wrong with that? Quinnipiac Law Review, Bridgeport, Conn., Law Review Association of the Quinnipiac College School of Law, v. 24, p. 25-62, 2005-2006. Disponível em: <http://www.quinnipiac.edu/prebuilt/pdf/SchoolLaw/LawReviewLibrary/09_24QLR25(20 05-2006).pdf>. Acesso em: 30 abr. 2014.

MALY, Heather. Publish at your own risk or don't publish at all: forum shopping trends in libel litigation leave the first amendment un-guaranteed. Journal of Law and Policy, v. 14, p. 889, 2006.

MANZI, Michael T. Dow Chemical Co. v. Castro Alfaro: the demise of forum non conveniens in Texas and one less barrier to international tort litigation. Fordham International Law Journal, v. 14, p. 822, 1990.

MARCATO, Antonio Carlos. Breves considerações sobre jurisdição e competência. Jus Navigandi, Teresina, ano 7, n. 56, 01 abr. 2002. Disponível em: <http://jus.com.br/artigos/2923>. Acesso em: 20 fev. 2014.

MARGIT, Livingston. Disobedience and contempt (civil and criminal contempt of court). Washington Law Review, v. 75, p. 349, 2000. 
MARLOWE, Christopher M. Forum non conveniens dismissals and the adequate alternative forum question: Latin America. The University of Miami Inter-American Law Review, v. 32, No. 2, p. 295-320, Spring/Summer, 2001.

MARTINS, Pedro Baptista. O abuso do direito e o ato ilícito. 3. ed. histórica, com considerações preliminares à guisa de atualização de José da Silva Pacheco. Rio de Janeiro: Forense, 1997.

MAZZOLA, Maria. Forum non conveniens and foreign plaintiffs: addressing the unanswered questions of Reyno. Fordham International Law Journal, v. 6, p. 582, 1982.

MCGHEE, John; SNELL, Edmund Henry Turner. Snell's equity. London: Sweet \& Maxwell, 2000.

MELKONIAN, Harry. Defamation, libel tourism and the SPEECH Act of 2010. Amherst, NY: Cambria Press, 2010.

MELLO, Celso D. Albuquerque de. Direito internacional público. 15. ed. rev. e aum. Rio de Janeiro: Renovar, 2004. v. 1.

MELLO, Celso Antônio Bandeira de. O conteúdo jurídico do princípio da igualdade. São Paulo: Malheiros, 2003.

MENEZES, Wagner. Tribunais internacionais: jurisdição e competência. São Paulo: Saraiva, 2013.

MERCURO, Nicholas; MEDEMA Steven G. Economics and the Law. Princeton: Princeton University Press, 1997.

MESQUITA, José Ignácio Botelho de. Da competência internacional e dos princípios que a informam. Revista de Processo, São Paulo, Revista dos Tribunais, v. 13, n. 50, p. 51-71, abr./jun. 1988.

MONACO, Gustavo Ferraz de Campos. Controle de constitucionalidade da lei estrangeira. São Paulo: Quartier Latin, 2013.

. Le droit applicable par la Cour: une question de droit international public ou de droit international privé harmonisé? In: COLLOQUE: UNE COUR CONSTITUTIONNELLE INTERNATIONALE AU SERVICE DU DROIT DÉMOCRATIQUE ET DU DROIT CONSTITUTIONNEL, 16 e 17 de junho de 2015, Rabat, Marrocos. Inédito.

. A proteção da criança no cenário internacional. Belo Horizonte: Del Rey, 2005.

MONACO, Gustavo Ferraz de Campos; JUBILUT, Lilliana Lyra. Direito internacional privado. São Paulo: Saraiva, 2012.

MONTEIRO, Washington Barros. Curso de direito civil: parte geral. 36. ed. São Paulo: Saraiva, 1999. v. 1. 
MOORE, Todd W. Untying our hands: the case for uniform personal jurisdiction over "libel tourists". Fordham Law Review, v. 77, p. 3.207, 2009.

MOREIRA, José Carlos Barbosa. Duelo e processo. Revista de Processo, São Paulo, Revista dos Tribunais, v. 28, n. 112, p. 177-185, out./dez. 2003.

O novo processo civil brasileiro, Rio de Janeiro: Forense, 1998.

Problemas relativos a litígios internacionais. In: . Temas de direito processual: quinta série. São Paulo: Saraiva, 1994. p. 139-162.

. Relações entre processos instaurados sobre a mesma lide civil, no Brasil e em país estrangeiro. In: ESTUDOS jurídicos em homenagem ao professor Oscar Tenório. Rio de Janeiro: Universidade do Estado do Rio de Janeiro (UERJ), 1977. p. 363-372.

A responsabilidade das partes por dano processual no direito brasileiro. In: Temas de direito processual civil: primeira série. São Paulo: Saraiva, 1988. p. 16-35.

MORELLI, Gaetano. Derecho procesal civil internacional. Buenos Aires: EJEA, 1953. . Trattato di diritto internazionale. Padova: CEDAM, 1938. v. 7.

MOSCHEN, Valesca Raizer Borges; SOUZA, Leandro Eloy. A solução europeia para a competência internacional. Revista de Processo, São Paulo, Revista dos Tribunais, v. 36, n. 192, p. 307-335, fev. 2011.

MOSS, Giuditta Cordero. Between private and public international law: exorbitant jurisdiction as illustrated by the Yukos Case. Review of Central and East European Law, Dordrecht; Boston: Martinus Nijhoff Publishers, v. 32, p. 11, 2007.

MUIR WATT, Horatia. Économie de la justice et arbitrage international (réflexions sur la gouvernance privée dans la globalisation. Revue de l'Arbitrage, Paris, n. 3, p. 389, 2008.

MULLIS, Alastair; SCOTT, Andrew. Tilting at windmills: the Defamation Act 2013. The Modern Law Review, v. 77, p. 88, 2014.

MYERSON, Roger B. Game theory: analysis of conflict. Cambridge, Mass.: Harvard University Press, 1991.

NEUMANN, John; MORGENSTER, Oskar. Theory of games and economic behavior. Princeton, NJ; Woodstock: Princeton University Press, 2007.

NIBOYET, Jean-Paulin. Traité de droit international privé français. Paris: Sirey, 1949. v. 6 , t. 2.

NORTH, Peter Machin; FAWCETT, J. J. Cheshire and North's private international law. 13th ed. London: Butterworths, 1999.

NUNES, Luiz Antônio Rizzatto. Manual de introdução ao estudo do direito. São Paulo: Saraiva, 1999. 
OESTREICHER, Yoav. "We're on a road to nowhere": reasons for the continuing failure to regulate recognition and enforcement of foreign judgments. The International Lawyer, v. 42 , n. 1 , p. $59-75$, Spring 2008

OPESKIN, Brian. The price of forum shopping: a reply to Professor Juenger. Sydney Law Review, v. 16, No. 1 p. 14-27, Mar. 1994. Disponível em:

<http://www.austlii.edu.au/au/journals/SydLRev/1994/2.pdf>. Acesso em: 10 maio 2014.

PAUL, Joel R. Comity in international law. Harvard International Law Review, v. 32, No. 1, p. 1-79, Winter 1991.

PEEL, Edwin. Forum shopping in the european judicial area: introductory report. Conference on Forum Shopping in the European Judicial Area. Oxford, UK: University of Oxford, 2006. (Oxford Legal Studies Research Paper, No. 39).

PEREIRA, Lafayette Rodrigues. Princípios de direito internacional. Rio de Janeiro: Jacintho Ribeiro dos Santos, 1902. v. 1.

PETSCHE, Markus. What's wrong with forum shopping? An attempt to identify and assess the real issues of a controversial practice. International Lawyer, v. 45, p. 1.005, 2011.

PICKER, Randall C. An introduction to game theory and the law. Chicago: University of Chicago Law School, 1994. (Coase-Sandor Institute for Law \& Economics Working Paper n. 22). Disponível em:

$<$ http://chicagounbound.uchicago.edu/cgi/viewcontent.cgi?article=1049\&context=law_and _economics>. Acesso em: 15 maio 2015.

PINHEIRO, Luís de Lima. Direito internacional privado: introdução e direito de conflitos. Reimpr. 2. ed., reimpr. Coimbra: Almedina, 2008. v. 1.

PINO, Giorgio. Il diritto e il suo rovescio: appunti sulla dottrina dell'abuso del diritto.

Rivista Critica del Diritto Privato, v. 1, p. 25-60, 2004. Disponível em: $<$ http://www1.unipa.it/gpino/Il\%20diritto\%20e\%20il\%20suo\%20rovescio.pdf>. Acesso em 15 maio 2015.

L'abuso del diritto tra teoria e dogmatica (precauzioni per l'uso). In: MANIACI, Giorgio (Org.). Eguaglianza, ragionevolezza e logica giuridica. Milano: Giuffrè, 2006. p. 115-175.

PIOVESAN, Flávia. Direitos humanos e o direito constitucional internacional. Sâo Paulo: Saraiva, 2008.

PLANIOL, Marcel. Précis de droit civil. Paris: Dalloz, 1929. v. 1.

PONTES DE MIRANDA, Francisco Cavalcanti. Comentários ao Código de Processo Civil: artigos 1 a 45. Atualização legislativa de Sérgio Bermudes. 5. ed. Rio de Janeiro: Forense, 1996. v. 1.

POSNER, Richard A. A economia da justiça. São Paulo: Martins Fontes, 2010. 
RADINSKY, Marla. Retaliation: the genesis of a law and the evolution toward international cooperation: an application of game theory to modern international conflicts. George Mason University Law Review, v. 2, n. 53, p. 54-75, Fall 1994.

RAMOS, André de Carvalho. Direitos humanos em juízo. São Paulo: Max Limonad, 2001.

RAMOS, Rui Manuel Gens de Moura. A recente reforma do direito processual civil internacional em Portugal. In: BAPTISTA, Luiz Olavo; FONSECA, José Roberto Franco da (Coords.). O direito internacional no terceiro milênio: estudos em homenagem ao professor Vicente Marotta Rangel. São Paulo: LTR, 1998. p. 793-821.

. Previsão normativa e modelação judicial nas convenções comunitárias relativas ao direito internacional privado. In: . Estudos de direito internacional privado e de direito processual civil internacional. Coimbra: Coimbra Editora, 2002. p. 93-124. 1998. A reforma do direito processual civil internacional. Coimbra: Coimbra Editora,

RÁO, Vicente. O direito e a vida dos direitos. 5. ed. anotada e atual. por Ovidio Rocha Barros Sandoval. São Paulo: Revista dos Tribunais, 1999.

RAPHAEL, Thomas. The anti-suit injuction. Oxford: Oxford University Press, 2008.

RAPOPORT, Anatol. Lutas, jogos e debates. Tradução de Sergio Duarte. Brasília: Ed. Universidade de Brasília, 1980.

RAWLS, John. A theory of justice. Cambridge, MA: Belknap Press of Harvard University Press, 1971.

RENDLEMAN, Doug. Complex litigation: injuctions, structural remedies and contempt, supplement: procedural rules, statutes, court documents. New York: Foundation Press, 2009.

REQUEJO ISIDRO, Marta. Proceso en el extranjero y medidas antiproceso: (antisuit injunctions). Santiago de Compostela: Servicio de Publicacións da Universidade de Santiago de Compostela, 2000.

REUS, Alexander. Judicial discretion: a comparative view of the doctrine of forum non conveniens in the United States, the United Kingdom, and Germany. Loyola of Los Angeles International and Comparative Law Review, v. 16, p. 455-511, 1994. Disponível em: <http://digitalcommons.lmu.edu/cgi/viewcontent.cgi? article=1329\&context=ilr>. Acesso em: 15 maio 2015.

REYDAMS, Luc. Universal jurisdiction: international and municipal legal perspective. New York: Oxford University Press, 2003.

RIGGS, Adrian. The impact of recent judgments of the European Court on english procedural law and practice. Zeitschrift fur Schweizerisches Recht, v. 2, n. 124, p. 233, 2005. 
ROBERTSON, David W. Forum non conveniens in America and England: a rather fantastic fiction. Law Quarterly Review, v. 103, p. 398, 1987.

ROBINSON, Darren J. U.S. enforcement of foreign judgments, libel tourism and de SPEECH Act: protecting speech or discouraging foreign legal cooperation? Transnational Law \& Contemporary Problems, v. 21, p. 911, 2012-2013.

RODAS, João Grandino. Direito internacional privado brasileiro. São Paulo: Revista dos Tribunais, 1993.

. Evolução do liame entre sociedade comercial e estado. Tese (Professor Titular) Faculdade de Direito da Universidade de São Paulo, São Paulo, 1993.

Sociedade comercial e Estado. São Paulo: Editora UNESP, 1995.

RODAS, João Grandino; MONACO, Gustavo Ferraz de Campos. Conferência da Haia de Direito Internacional Privado: a participação do Brasil. Brasília: Fundação Alexandre de Gusmão, 2007.

ROPPO, Enzo. O contrato. Coimbra: Almedina, 1988.

ROSENFELD, Michel. Just interpretations: law between ethics and politics. Berkeley: University of California Press, 1998.

ROSSOLILLO, Giulia. Forum necessitatis e flessibilità dei criteri di giurisdizione nel diritto internazionale privato nazionale e dell'Unione Europea. Cuadernos de Derecho Transnacional, Madrid, v. 2, n. 1, p. 403-418, mar. 2010. Disponível em:

<http://hosting01.uc3m.es/Erevistas/index.php/CDT/article/viewFile/110/108>. Acesso em: 10 maio 2014.

RÜHL, Giesela. Choice of law and choice of forum in the European Union: recent developments. In: HODGES, Christopher; VOGENAUER, Stefan (Coords.). Civil justice systems in Europe: implications for choice of forum and choice of contracts law. Oxford: Hart Publishing, 2010.

RUSBRIDGER, Alan. How to stifle the press: England has become the world capital of libel. With a few tricks and a good lawyer, anyone can cover up an inconvenient truth. Spectator, 18 Sept. 2010. Disponível em:

<http://go.galegroup.com/ps/i.do?\&id=GALE|A237522693\&v=2.1\&u=capes\&it=r\&p=AO $\mathrm{NE} \& \mathrm{sw}=\mathrm{w} \&$ authCount=1>. Acesso em: 16 maio 2015.

RUSSELL, Kathryn A. Exorbitant jurisdiction and enforcement of judgments: the Brussels system as an impetus for the United States action. Syracuse Journal of International Law and Commerce, v. 19, p. 2, Spring, 1993.

SANTOS, Moacyr Amaral. Primeiras linhas de direito processual civil. 5. ed. São Paulo: Saraiva, 1977. v. 1. 
SÃO VICENTE, José Antonio Pimenta Bueno, Marquês de. Direito internacional privado e aplicação de seus princípios com referência às leis particulares do Brasil. Rio de Janeiro: Typographia Imp. e Const. de J. Villeneuve E.C., 1863.

SAVIGNY, Friedrich Carl von. Sistema do direito romano atual. Tradução de Ciro Mioranza. Ijuí, RS: Unijuí, 2004.

SHAFFER, Thomas L. Unique, novel, and unsound adversary ethic. Vanderbilt Law Review, v. 41, p. 712, 1988).

SILVA, Alexandre Assunção e. Liberdade de expressão e crimes de opinião. São Paulo: Atlas, 2012.

SILVA, Agustinho Fernandes Dias da. Direito processual internacional: efeitos internacionais da jurisdição brasileira e reconhecimento de jurisdição estrangeira no Brasil. Rio de Janeiro: Villani Filhos, 1971.

SILVA, Luis Virgílio Afonso da. O proporcional e o razoável. Revista dos Tribunais, São Paulo, v. 91, n. 798, p. 23-50, abr. 2002.

SIMOWITZ, Aaron D. A U.S. perspective on forum shopping, ethical obligation, and international commercial arbitration. In: FERRARI, Franco (Ed.). Forum shopping in the international commercial arbitration context. Munich: Sellier European Law Publishers (SELP), 2013. p. 1-21.

SLONIMSQUI, Pablo. Forum shopping. Buenos Aires: Fabián J. di Plácido Editor, 2008.

SMIT, Hans. Common and civil law rules of in personam adjudicatory authority: an analysis of underlying policies. International and Comparative Law Quarterly, Cambridge, v. 21 , No. 1, p. $335,1972$.

The terms jurisdiction and competence in comparative law. American Journal of Comparative Law, Berkeley, v. 10, No. 1, p. 164-169, 1961.

SOARES, Guido Fernando Silva. A competência internacional do judiciário brasileiro e a questão da autonomia da vontade das partes. In: BAPTISTA, Luiz Olavo; CASELLA, Paulo Borba; HUCK, Hermes Marcelo (Coords.). Direito e comércio internacional: tendências e perspectivas: estudos em homenagem ao prof. Irineu Strenger. São Paulo: LTr, 1994. p. 283-305.

Das imunidades de jurisdição e de execução. Rio de Janeiro: Forense, 1984.

STANKO, Andrej. Cross border "torpedo" litigation. Common Law Review, n. 10, p. 23, 2009. Disponível em: <http://www.commonlawreview.cz/cross-border-qtorpedoqlitigation>. Acesso em: 15 maio 2015. 
STAVELEY-O'CARROLL, Sarah. Libel tourism laws: spoiling the holiday ad saving the First Amendment? New York University Journal of Laws \& Liberty, v. 4, No. 3, p. 252292, Feb. 2009. Disponível em:

<http://www.law.nyu.edu/sites/default/files/ECM_PRO_062709.pdf>. Acesso em: 10 maio 2014.

STEINMETZ, Wilson Antônio. Colisão de direitos fundamentais e o princípio da proporcionalidade. Porto Alegre: Livraria do Advogado, 2001.

STEPHAN, Paul B. A becoming modesty: U.S. litigation in the mirror of international law. Depaul Law Review, v. 52, p. 627, 2002.

STERNLIGHT, Jean R. Panacea or corporate tool? Debunking the Supreme Court's preference for binding arbitration. Washington University Law Review, v. 74, p. 637, 1996.

STEWART, Charles Evan. The government suspension provision of the Clayton Act's statute of limitations: for whom does it toll? St. John's Law Review, v. 60, p. 70, 1985.

STEWART, Margareth G. Forum non conveniens: a doctrine in search of a role. California Law Review, v. 74, p. 1.275, 1986.

STOCO, Rui. Abuso do direito e má-fé processual: aspectos doutrinários. São Paulo: Revista dos Tribunais, 2002.

STRENGER, Irineu. Arbitragem comercial internacional. São Paulo: LTr, 1996.

. A autonomia da vontade como suporte do sistema civilista e direito internacional privado e direito interno. Boletim Científico da Escola do Ministério Público da União, Brasília, v. 3, n. 10, p. 70, jan./mar. 2004.

. Autonomia da vontade em direito internacional privado. São Paulo: Revista dos Tribunais, 1968.

. Contratos internacionais do comércio. São Paulo: LTr, 2003.

. Curso de direito internacional privado. Rio de Janeiro: Forense, 1978.

Direito internacional privado. São Paulo: LTr, 2003.

Direito processual internacional. São Paulo: LTR, 2003.

STRUYVEN, Olivia. Exorbitant jurisdiction in the Brussels Convention. Jura Falconis, Leuven, Bélgie, Katholieke Universiteit Leuven, v. 35, No. 4, p. 522, 1998. Disponível em: <http://www.law.kuleuven.be/jura/art/35n4/struyven.htm>. Acesso em: 30 abr. 2014).

STURTEVANT, Tara. Can the United States talk the talk \& walk the walk when it comes to libel tourism: how the freedom to sue abroad can kill the freedom of speech at home. Pace International Law Review, v. 22, p. 269, 2010. 
TARUFFO, Michele. Elementi per una definizione di "abuso del processo". In: STUDI in onore di Pietro Rescigno: responsabilità civile e tutela dei diritti. Milano: Giuffrè, 1998. v. 5, p. 1.117-1.135.

TENÓRIO, Oscar. Direito internacional privado. Rio de Janeiro: Freitas Bastos, 1967. v. 1.

Direito internacional privado. Rio de Janeiro: Freitas Bastos, 1970. v. 2.

\section{5.}

. Lei de Introdução ao Código Civil brasileiro. 2. ed. aum. Rio de Janeiro: Borsoi,

THEODORO JÚNIOR, Humberto. Curso de direito processual civil. Rio de Janeiro: Forense, 2005. v. 1.

. O princípio da probidade e a repressão à litigância de má-fé. COAD Seleções Jurídicas, v. 11, p. 18, 1990.

. Relatório brasileiro: abuso do direito processual no ordenamento jurídico brasileiro. In: MOREIRA, José Carlos Barbosa (Coord.). Abuso dos direitos processuais: relatórios ibero-americanos apresentados ao Simpósio da Associação Internacional de Direito Processual. Rio de Janeiro: Forense, 2000. p. 699-738.

TIBURCIO, Carmen. A eleição de foro estrangeiro e o judiciário brasileiro. Revista de Direito de Estado, Renovar, n. 12, p. 379-384, out./dez. 2008.

TORNAGHI, Helio. Comentários ao Código de Processo Civil: arts. 1 a 153. São Paulo: Revista dos Tribunais, 1974. v. 1.

TORRENTE, Andrea, Emulazione (diritto civile). In: NOVISSIMO Digesto Italiano. Torino: UTET, 1975. v. 6.

TUCCI, José Rogério Cruz e. Repressão ao dolo processual: o novo art. 14 do CPC. Revista Jurídica, Porto Alegre, Notadez, v. 50, n. 292, p. 15-27, 2002.

Tempo e processo: uma análise empírica das repercussões do tempo na fenomenologia processual (civil e penal). São Paulo: Revista dos Tribunais, 1997.

UBALDO, Edson Nelson. O Protocolo de Las Leñas: vantagens - problemas - sugestões. In: IRIGOIN BARRENE, Jeannette (Coord.). Chile y el Mercosur en América Latina: VI Encuentro Internacional de Derecho de América del Sur. Santiago: Editorial Juridica de Chile, 1999. v. 1, p. 387-406.

UBERTAZZI, Benedetta. Intellectual property rights and exclusive (subject matter) jurisdiction: between private and public international law. Marquette I.P. Law Review, v. 15, p. 366, 2011.

USUNIER, Laurence. La regulation de la competence jurisdictionnelle en droit international privé. Paris: Eonomica, 2008. 
VALLADÃO, Haroldo. Da competência judiciária no direito internacional privado. In: . Estudos de direito internacional privado. Rio de Janeiro: J. Olympio, 1947.

. Direito internacional privado. Rio de Janeiro: Freitas Bastos, 1983. v. 1.

Unidade ou pluralidade da sucessão e do inventário e partilha no direito

internacional privado. Revista dos Tribunais, São Paulo, v. 93, n. 830, p. 717-746, dez. 2004.

VANDERMEULEN, Bruno. The next generation of cross-border litigators. Disponível em: <http://www.managingip.com/Article/1321504/The-next-generation-of-cross-borderlitigators.html>. Acesso em: 27 out. 2013).

VARDI, Nathan. The world's billionaires: sins of the father?. Forbes, 18 March 2002. Disponível em: <http://www.forbes.com/global/2002/0318/047.html>. Acesso em: 16 maio 2015.

VÉRON, Pierre. Italian torpedoes: an endangered weapon in french courts? International Review of Industrial Property and Copyright Law IIC, Munich, v. 33, n. 2, p. 227-230, 2002.

VON MEHREN, Arthur Taylor. Must plaintiffs seek out defendants? The contemporary standing of actor sequitur forum rei. The Kings College Law Journal, v. 8, p. 23-42, 1997 1998.

Recognition and enforcement of foreign judgments: a new approach for the Hague Conference? Law and Contemporary Problems, Durham, NC, v. 57, n. 3, p. 272, Summer 1994.

Theory and practice of adjudicatory authority. Recueil des Cours de l'Académie de Droit International de La Haye, v. 295, p. 395, 2002.

WHITE, Robin M.; WILLOCK, Ian D.; MACQUEEN, Hector L. The scottish legal system. 5th ed. Edinburgh: Bloomsbury Professional, 2013.

WHITTEN, Ralph U. Improving the "better law" system: some impudent suggestions for reordering and reformulating leflar's choice-influencing considerations. Arkansas Law Review, v. 52, p. 177, 1999.

WOLFF, Martin. Private international law. 2nd. ed. Oxford: Clarendon Press, 1950.

WRIGHT, Skelly. The federal courts and the nature and quality of state law. Wayne Law Review, v. 13, p. 317-333, 1967.

ZYWICKI, Todd J. Is Forum shopping corrupting America's Bankruptcy Courts? The Georgetown Law Journal, Washington, DC, v. 94, No. 4, p. 1.141-1.195, April 2006. Disponível em: <http://papers.ssrn.com/sol3/papers.cfm?abstract_id=781487>. Acesso em: 30 abr. 2014. 